\author{
UNIVERSIDADE DE SÃO PAULO \\ FFCLRP - DEPARTAMENTO DE PSICOLOGIA E EDUCAÇÃO \\ PROGRAMA DE PÓS-GRADUAÇÃO EM PSICOLOGIA
}

\title{
Os bastidores da relação família-escola
}

Daniela de Figueiredo Ribeiro

Tese apresentada à Faculdade de Filosofia, Ciências e Letras de Ribeirão Preto da USP, como parte das exigências para a obtenção do título de Doutora em Ciências. Área: Psicologia.

Ribeirão Preto - SP

2004 



\author{
UNIVERSIDADE DE SÃO PAULO \\ FFCLRP - DEPARTAMENTO DE PSICOLOGIA E EDUCAÇÃO \\ PROGRAMA DE PÓS-GRADUAÇÃO EM PSICOLOGIA
}

\title{
Os bastidores da relação família-escola
}

Daniela de Figueiredo Ribeiro

Prof. Dr. Antônio dos Santos Andrade

Tese apresentada à Faculdade de Filosofia, Ciências e Letras de Ribeirão Preto da USP, como parte das exigências para a obtenção do título de Doutora em Ciências. Área: Psicologia.

Ribeirão Preto - SP

2004 
FICHA CATALOGRÁFICA

Ribeiro, Daniela de Figueiredo

Os bastidores da relação família-escola.

Ribeirão Preto, 2004.

283 p. : il.; $30 \mathrm{~cm}$

Tese, apresentada à Faculdade de Filosofia, Ciências e Letras de Ribeirão Preto / USP - Departamento de Psicologia e Educação.

Orientador: Andrade, Antônio dos Santos

1. Escola Pública 2. Relação família-escola 3. Sociodrama educacional 
Dedico este trabalho aos agentes escolares e aos pais e mães que gentilmente abriram suas portas (não somente as de suas casas) para me deixar adentrar seu mundo.

É com todo respeito que eu lhes ofereço as alegrias e os esforços contidos na execução deste trabalho.

Com eles, alinho o meu desejo: de um mundo mais justo e de uma humanidade mais amorosa. 


\section{AGRADECIMENTO ESPECIAL}

Ao Prof. Dr. Antônio dos Santos Andrade, orientador do atual estudo, a quem este trabalho deve seu "sopro" e inspiração.

Foi graças ao seu olhar, sua atenção e sua condução que este trabalho se desenvolveu e tomou a forma atual.

Ele acolheu, no decorrer do processo, os impasses, as dúvidas e os abismos que não deixaram de existir no percurso.

Ele doou também, sem fazer contas, suas reflexões de anos em uma trajetória crítica, iluminando, sempre que necessário, os horizontes que eu, aprendiz, não alcançava.

Então, no processo deste trabalho eu percebo sua co-autoria do início ao fim: propondo uma leitura crítica da literatura, fornecendo um instrumento para a apreensão da realidade estudada - uma metodologia de trabalho - e buscando desenvolver, em seu grupo de pesquisa, um modo de pensar os resultados, de forma que o movimento da realidade não seja excluído da análise.

Nos oito anos em que o acompanho, observo que o Toninho vem humildemente construindo seu trabalho de forma séria, competente e ética, sobretudo. Nos termos de Chauí (1999), trabalho ético seria aquele que viesse a contribuir para a ruptura do fazer ideológico. Significa, ainda, estar engajado, comprometido com a realidade social.

Afirmo aqui minha gratidão às pérolas generosamente por ele doadas. 


\section{AGRADECIMENTOS (também especiais)}

À Profa. Dra. Zélia Maria M. Biasoli Alves, por ter possibilitado que este estudo, inicialmente um projeto de dissertação, ganhasse a dimensão de uma tese. Eu claramente reconheço, hoje, o quanto essa mudança foi fundamental, tanto para o próprio estudo, que ganhou o tempo necessário para que pudesse ser aprofundado, quanto para o meu desenvolvimento enquanto pesquisadora. Agradeço ainda a essa semeadora incansável, pelas inúmeras oportunidades de aprendizagem e crescimento.

À Profa. Dra. Vânia M. J. Nassif, pela leitura atenta, pelo envolvimento e disponibilidade em trocar. Também pelas sugestões valiosas que o trabalho seguiu e que foram de suma importância.

À Profa. Dra. Silvia R. R. L. Sigolo, pelas sugestões dadas a outros trabalhos do Grupo de Estudo e Pesquisa em Sociodrama Educacional, que o atual estudo buscou seguir, e pela disponibilidade em participar de mais uma banca examinadora de trabalhos do grupo.

À Profa. Dra. Regina H. L. Caldana, pelo acompanhamento no desenvolvimento do meu papel profissional, tendo sido, desde a graduação, uma presença importante.

Ao Prof. Dr. Luiz Felipe Guimarães Soares, pela indicação de novos horizontes nos quais o atual estudo ainda pode se lançar e que, sem dúvida, lhe trarão valiosas contribuições. Ainda, pela dedicação e competência na correção do trabalho.

Aos membros do Grupo de Estudo e Pesquisa em Sociodrama Educacional: Christina, Valéria, Fátima, Eliane, Cristiane, Márcio, Beatriz, Patrícia, Karina, Gislaine, Zilda, pelas descobertas conjuntas, pela cumplicidade e solidariedade vividas.

A todos os participantes da pesquisa, que deram a ela seu tom e sem os quais o atual estudo não se viabilizaria. 


\section{AGRADEÇO IMENSAMENTE AINDA:}

A todos os verdadeiros Mestres que a vida me proporcionou e que, tenho certeza, participam de quaisquer frutos que este trabalho venha a produzir.

Ao Mique, companheiro pessoal e profissional, co-criador deste estudo, por toda ajuda concreta para que eu pudesse me dedicar a ele, pelo apoio afetivo e pelos momentos de interlocução e 'fermentação' de idéias. Na certeza de que o nosso caminho também nele se revelou.

À Gi, amiga sempre presente, iniciadora e tutora na pós-graduação, 'fadamadrinha' deste estudo: por lançar tanta luz no meu percurso, incentivar, acolher, dar idéias, criar junto.

A minha família, pela confiança e por todo incentivo e ajuda para que fosse dedicado o tempo necessário à consecução deste trabalho. Agradeço ainda à Fer, pela competente transformação das minhas idéias em imagens e pela doação de sua arte nas composições gráficas do atual estudo; à Reka, pela ajuda nos momentos de "sufoco"; à vó Odette, grande incentivadora e aquela que primeiro leu o atual estudo; à vó Lourdes, pela atenção e pelos mimos sempre presentes; à madrinha e ao Bob, pelo carinho e valiosa ajuda com o inglês; ao meu pai, pela eterna disposição em ajudar, e à minha mãe, pelo acolhimento e escuta.

Agradeço mais especificamente aos educadores da minha vida: além dos meus pais, minha sogra e minhas avós, pelo modelo de atuação inovadora e pela dedicação absoluta às suas práticas.

À Andréia, Adriana e Jane, pelo carinho e pelo auxílio na confecção deste trabalho.

Ao João, pela disponibilidade e pela competência na execução da maioria das fotos apresentadas. 
"Não se trata de negar o que sabemos, trata-se de relativizar nosso conhecimento. Conscientizarmo-nos de que o que sabemos não é tudo, de que o que sabemos não é grande coisa diante de tudo o que resta a descobrir. Esta é a atitude do verdadeiro cientista. Ele sabe o que sabe. Mas sabe também que seu saber é limitado e o que ele não sabe é infinito."

Jean-Yves Leloup 


\section{RESUMO}

RIBEIRO, Daniela de Figueiredo. Os bastidores da relação família-escola. $283 \mathrm{f}$. Tese (Doutorado) - Faculdade de Filosofia, Ciências e Letras de Ribeirão Preto, Universidade de São Paulo, Ribeirão Preto, 2004.

A partir dos anos 60, após pesquisas internacionais terem apontado o peso da origem social nas trajetórias de escolarização, muitas dificuldades escolares passaram a ser atribuídas às famílias populares, que tidas como deficitárias do ponto de vista sóciocultural, não podiam proporcionar estímulos suficientes ao desenvolvimento dos filhos. Essas famílias passaram a ser, então, chamadas à escola no intuito de serem normatizadas, sob o pretexto de uma educação compensatória. Com base na literatura, o que se observa, atualmente, é uma naturalização das práticas de envolvimento dos pais na vida escolar dos filhos, o que é comumente visto como fundamental para o sucesso da escolarização. No entanto, as reais possibilidades das famílias em executar as tarefas a elas atribuídas parecem ser ainda desconhecidas pelos agentes escolares. Daí a importância de se conhecer seu ponto de vista: como os pais, atores sociais concretos, estão vivendo a relação com a escola dos filhos. $\mathrm{O}$ objetivo do atual estudo é, então, investigar as representações e vivências de pais de alunos sobre a escola pública em que os filhos estudam. A abordagem teórico-metodológica adotada segue os referenciais teóricos do Psicodrama, da Análise Institucional e da Etnografia. Foram utilizados os seguintes métodos de coleta de dados: observação participante na escola, com vistas ao conhecimento do contexto mais amplo; entrevistas individuais com 22 pais de alunos de $3^{\mathrm{a}}$ e $4^{\mathrm{a}}$ séries em suas residências; duas entrevistas em grupo focal com os pais entrevistados individualmente; e análise documental. A análise dos dados ocorreu segundo os moldes da análise de conteúdo tradicional, e as sessões grupais passaram também por uma análise sociométrica. Os resultados apontaram que os pais parecem conceber sua atuação na vida escolar dos filhos da forma como a escola prescreve. No entanto, ao relatar vivências, eles revelaram idiossincrasias, críticas e dificuldades em cumprir o que deles é esperado. A postura da maioria na entrevista individual foi defensiva, havendo alguns que se colocaram de forma acrítica e uma minoria que se mostrou mais crítica. As sessões em grupo se mostraram importantes, uma vez que possibilitaram que o drama coletivo, do qual os entrevistados pareciam se defender na entrevista individual, fosse compartilhado. Foi revelado, então, um sentimento comum de impotência diante das exigências da escola, a qual parece exercer mecanismos sutis de exclusão. Assim, a relação família-escola se mostrou assimétrica, não parecendo atingir sua meta última de propiciar uma efetiva ajuda na vida escolar dos alunos. Pelo contrário, observou-se que a maneira como essa relação vem ocorrendo tende a aumentar ainda mais a distância entre o conhecimento formal propagado pela escola e a realidade das famílias populares, principalmente aquelas mais desfavorecidas social e economicamente.

Palavras-chave: Relação Família-Escola. Escola Pública. Sociodrama Educacional. 


\begin{abstract}
RIBEIRO, Daniela de Figueiredo. Inside the School/Family Relationship, 283 pages (Doctoral dissertation) - Faculty of Philosophy, Science and Literature of Ribeirão Preto, University of São Paulo, Ribeirão Preto, 2004.

In the 1960s, international research began to emphasise the importance of social background in the performance of schoolchildren. In consequence, many of the difficulties which children experienced at school came to be attributed to the socially and culturally deprived family environments in which they were growing up, since their parents were not able to provide them with the stimulation necessary for satisfactory development. Both parents and children were, therefore, summoned by the school to take part in sessions which were intended to remedy this deficiency in stimulation. On consulting the literature available on this subject, it is evident the naturalization of the involvement of parents in the scholarly life of their children, and this is considered essential for successful schooling. Nevertheless, school authorities still appear to be unaware of the real situation regarding the ability of parents to carry out the obligations which have been placed on them. For this reason, it is of paramount importance to hear their point of view. How do parents, in this essential social role, perceive their relationship with their children's school? The purpose of this research is, therefore, to investigate parents' experiences vis-à-vis their relationship with the school where their children study. The theoretical-methodological approach adopted here is drawn from psychodrama, institutional analysis, and ethnography. The following methods were used for the collection of data: participative observation within the school environment, in order to be fully acquainted with as wide a context as possible; interviews held in their homes with 22 separate sets of parents of $3^{\text {rd }}$ and $4^{\text {th }}$ year students; two focus groups with the parents interviewed individually; and documental analysis. A traditional analytical approach was adopted to the data collected, whilst the group sessions were analysed sociometrically. The results of the analyses show that the parents seem to perceive their role in their children's schooling in line with the parameters outlined by the school. However, when they described their own personal experiences, they revealed idiosyncrasies, voiced criticisms, and talked about difficulties they faced in doing what the school expected of them. Most of them adopted a defensive stance during the individual interviews; some were acritical, and relatively few were critical. The group sessions were important because they allowed participants to share their collective drama, being less defensive than they were in the individual interviews. In these sessions, the participants revealed a sense of impotence in the face of demands imposed on them by the school, which seems to exercise subtle mechanisms of exclusion. As a result, the relationship between parents and school was asymmetrical, and the overriding aim of getting the parents to play a more significant role in the scholarly life of children was not achieved. On the contrary, it was observed that the relationship in its present form tends to increase the distance between the formal approach to learning favoured by the school, and the reality of underprivileged families, especially those who are most deprived socially and economically.
\end{abstract}

Keywords: Family/School Relationship. State School. Educational Sociodrama. 


\section{Lista de Quadros}

Quadro 1 - Pais entrevistados individualmente

p. 87

Quadro 2 - Participantes das entrevistas em grupo focal

p. 88

Quadro 3 - Caracterização Geral das Famílias

p. $120-1$

Quadro 4 - Postura dos entrevistados no decorrer da entrevista individual

p. 155 


\section{Sumário}

$\begin{array}{lr}\text { Resumo } & \text { p. } 10\end{array}$

$\begin{array}{ll}\text { Abstract } & \text { p. } 11\end{array}$

$\begin{array}{ll}\text { Apresentação } & \text { p. } 15\end{array}$

$\begin{array}{lr}\text { CAPÍTULO I - INTRODUÇÃO } & \text { p. } 17\end{array}$

I - Construindo o objeto de pesquisa: delineamento teórico-conceitual p. 17

$\begin{array}{ll}\text { II- Contextualização sócio-histórica do tema } & \text { p. } 35\end{array}$

$\begin{array}{ll}\text { III - Brasil: cenário da escola pública } & \text { p. } 48\end{array}$

IV - Estudos recentes sobre o papel da família na escolarização dos filhos p. 58

$\begin{array}{lr}\text { V- As relações institucionais } & \text { p. } 65\end{array}$

VI - As representações dos professores sobre o aluno e sua família

$\begin{array}{ll}\text { VII - As representações dos pais sobre a escola } & \text { p. } 72\end{array}$

$\begin{array}{lr}\text { VIII - Justificativa } & \text { p. } 77\end{array}$

$\begin{array}{lr}\text { IX - Objetivos do atual estudo } & \text { p. } 79\end{array}$

$\begin{array}{lr}\text { CAPÍTULO II - METODOLOGIA } & \text { p. } 80\end{array}$

$\begin{array}{ll}\text { I - Abordagem teórico-metodológica } & \text { p. } 80\end{array}$

$\begin{array}{lr}\text { II - Participantes } & \text { p. } 84\end{array}$

$\begin{array}{lr}\text { III - Procedimentos da pesquisa de campo } & \text { p. } 88\end{array}$

$\begin{array}{lr}\text { IV - Análise dos dados } & \text { p. } 92\end{array}$

$\begin{array}{lr}\text { CAPÍTULO III - RESULTADOS } & \text { p. } 95\end{array}$

$\begin{array}{ll}\text { I - O contexto da pesquisa } & \text { p. } 95\end{array}$

$\begin{array}{ll}\text { II- Resultados relativos às entrevistas individuais } & \text { p. } 146\end{array}$

III- Resultados relativos às entrevistas em grupo focal p. 194

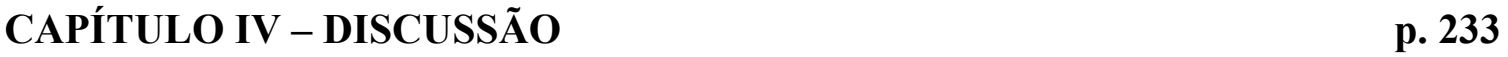


CAPÍTULO V - CONCLUSÃO

P. 254

CAPÍTULO VI - Aplicações práticas do atual estudo:

p. 256

Projeto de intervenção

POST SCRIPTUM

P. 258

REFERÊNCIAS BIBLIOGRÁFICAS

p. 259

ANEXOS

p. 264 


\section{APRESENTAÇÃO}

"No começo é a relação.(...) O homem se torna Eu na relação com o Tu."

(Martin Buber, Eu e Tu, 1974, p. 21,32)

O atual estudo se iniciou como continuidade de um trabalho anterior (RIBEIRO, 2000), realizado sob a orientação do Prof. Dr. Antônio dos Santos Andrade. Foi efetuada, então, uma pesquisa-intervenção de cunho sociodramático, com profissionais de saúde que atendiam pacientes soropositivos ao HIV. Este trabalho resultou na monografia para obtenção do título de psicodramatista pela Federação Brasileira de Psicodrama e representou o início da trajetória no Grupo de Estudo e Pesquisa em Sociodrama Educacional.

Assim, foram escolhidos antes o orientador e um modo de pesquisar, e só depois um tema de pesquisa, pois até então eu havia me dedicado a estudos na área da saúde, sendo minha atuação profissional predominantemente clínica.

Portanto, entrar no universo da Educação foi um grande desafio, ao mesmo tempo rico e sofrido, pois é uma área que tem uma produção crítica importante, revelando aspectos da realidade social vivida por todos nós.

Pensar em família e pensar em escola, as duas principais instituições que atuam como nossas matrizes de identidade, foi impossível sem que eu questionasse a mim mesma, meu trabalho como psicóloga, minha inserção no mundo.

Comparando a sociedade em que vivemos a um formigueiro, onde as palavras de ordem são a eficiência e a inclusão no mundo do trabalho, pode-se dizer que o que mais se almeja é tornar-se uma boa formiga. A boa formiga pode ser comparada à metáfora do homem-máquina. Sem alma, sem subjetividade: dispositivo de manutenção de uma ordem que ele próprio desconhece.

Nesse contexto, o que significa ser uma boa escola? Preparar bem as crianças para se adaptarem ao formigueiro? Adestrá-las, moldá-las ?

Com vistas a que buscamos a transformação da escola e da sociedade? Essa é a questão na qual eu busco permanecer, firmando com ela meu compromisso, lembrando 
que, segundo Chauí (1999), ética, no seu sentido estrito, significa o reconhecimento por parte do sujeito daquilo que lhe é próprio, no sentido de sua autonomia, da sua liberdade. Essa autora aponta um claro conflito entre a vontade do sujeito ético e os valores morais de sua sociedade.

Assim, o atual estudo, longe de ter alguma pretensão de verdade, revela apenas uma compreensão momentânea, o ponto de chegada diante das rupturas que foram possíveis (rumo a uma maior autonomia) durante o processo. Ressalto, ainda, que as reflexões a que se chegou foram construídas com base nas várias interlocuções que ocorreram durante a fase de criação. E foram vários os seus co-criadores.

Hoje me encontro numa etapa do caminho em que nem me lembro bem de onde parti. O mundo em que eu vivia se transformou. Houve crises e desestabilizações, mas percebo que esse processo é inerente ao aprender.

Termino, nesse momento, ainda com sede, com desejo de continuar, de tornarme não somente psicóloga e pesquisadora, mas um ser humano que compreende o mundo em que vive. 


\section{CAPÍTULO I - INTRODUÇÃO}

O nômade é sempre um estranho

No oásis

Estranhamente estrangeiro

Diante daquilo que não pára de sonhar

O escritor, ele também é um nômade

De livro em livro

Como de um oásis ou de um poço

A outro

Ninguém é sua morada

Mesmo que cada um mate a sede

Sua sede - responde à pergunta

De um momento

Ninguém sacia seu desejo

Ninguém é a terra prometida

$O$ silêncio prometido

É caminhando

É no deserto

Que ele conhece o belo silêncio

Obsessionado pela Fonte"

(Jean-Yves Leloup, Deserto, desertos. p.72, 1998)

\section{I - Construindo o objeto de pesquisa: delineamento teórico-conceitual}

\section{1- A relação família-escola como tema}

Até meados do século XX, predominava na educação uma visão de inspiração funcionalista, que atribuía à escolarização um papel de superação do atraso econômico, do autoritarismo e dos privilégios sociais. Através dela, buscava-se uma sociedade mais justa (meritocrática), moderna (centrada nos conhecimentos científicos) e democrática (fundamentada na autonomia individual). A escola, nessa perspectiva, era tida como neutra, difusora de um conhecimento racional, científico e que selecionava os alunos com base em critérios objetivos e neutros. No final dos anos 50, uma série de grandes 
pesquisas internacionais apontou o peso da origem social sobre os destinos escolares, colocando em choque o paradigma funcionalista (NOGUEIRA; NOGUEIRA, 2002)2.

Essa constatação redirecionou as pesquisas, que passaram a investigar o déficit cultural de algumas famílias, que as impossibilitavam de ter filhos com aproveitamento escolar satisfatório. Daí surgiu a necessidade de incluir como objeto de estudo, na pesquisa educacional, o tema relação família-escola. É importante ressaltar, que nesse primeiro momento, o intuito era confirmar as desvantagens sociais das minorias étnicas e da população socialmente desfavorecida e, tanto os estudos empíricos quanto as intervenções, enfatizavam a compreensão e a prevenção do fracasso escolar partindo do âmbito familiar. Nos Estados Unidos, por exemplo, iniciou-se um programa de educação compensatória, ou seja, um treinamento de mães para que pudessem contribuir efetivamente com a educação formal dos filhos (CARVALHO, 2000).

Assim, as dificuldades com relação à educação dos filhos passaram a estar nas famílias populares, que pelas carências sócio-culturais não podiam proporcionar estímulos suficientes ao desenvolvimento escolar dos filhos. Fica muito clara, então, a visão de um modelo genérico e idealizado de família, o das classes médias e superiores. Essa abordagem pode ser definida como tendo uma tendência ambientalista (ZAGO, 1998).

A relação entre a família e a escola começou a ser efetivamente estudada, na sociologia da educação, a partir dos anos 60 . Antes disso, o tema não era considerado importante, porque tanto a casa quanto a sala de aula eram espaços privados, não havendo entre eles, relações estreitas. Os pais não eram admitidos no recinto da escola e, quando solicitados, era para resolver questões de vestuário e manutenção da ordem. Foi somente a partir dos anos 60 que começaram a ocorrer interações individuais entre pais e professores, mas elas não chegavam a incidir sobre o terreno pedagógico. Antes disso, na década de 50, ao se tratar do tema família-escola, a corrente do "empirismo metodológico" predominou, centrando-se na relação entre educação e classe social. O objetivo era identificar os fatores responsáveis pelas desigualdades de oportunidades, e as análises tinham um caráter quantitativo e macroscópico (NOGUEIRA, 1998).

Dos anos 60 aos anos 70, surgiram as correntes estruturalistas, e a família foi colocada no centro das análises porque, ao transmitir um patrimônio cultural e

\footnotetext{
${ }^{2}$ As referências bibliográficas seguem as normas de publicação da American Psychological Association (4ª edição, 1994), já que essas são comumente adotadas em publicações científicas da área.
} 
ideológico e produzir as aspirações escolares em conformidade com a sua condição de classe, ela acabava por determinar as trajetórias e condutas escolares dos filhos.

As teorias da reprodução também se destacaram nessa época e avançaram no sentido de uma diferenciação da natureza das famílias segundo seu pertencimento de classe. As variáveis clássicas utilizadas eram: condições materiais de existência e background sócio-cultural (NOGUEIRA,1998).

Um dos expoentes reprodutivistas foi Pierre Bourdieu. Nogueira \& Nogueira (2002) apontam que, para esse autor, a escola acabava por reproduzir e legitimar os privilégios sociais, uma vez que o conteúdo ensinado advinha de um arbitrário cultural (cultura da classe dominante). Os alunos com acesso à cultura dominante tinham muito mais condições de obter sucesso escolar. A legitimação ocorria quando as desigualdades não eram colocadas como decorrentes do sistema educacional e de oportunidades diferenciadas, mas sim das diferenças acadêmicas e cognitivas relacionadas aos méritos e dons individuais. A educação escolar para crianças provenientes de meios culturalmente favorecidos aconteceria como uma continuação da educação familiar, enquanto que para outras crianças de camadas baixas, o ensino escolar seria distante e estranho. Dessa forma, pelo acúmulo histórico de experiências de êxito ou fracasso, os grupos sociais construiriam, inconscientemente, um conhecimento do que é ou não possível alcançar através da escolarização. Isso significa que cada grupo social tenderia a investir uma parcela maior ou menor de seus esforços na carreira escolar dos filhos, conforme percebessem maiores ou menores probabilidades de êxito.

As críticas ao trabalho de Bourdieu têm sido feitas com relação ao seu conceito de classe social. As pesquisas têm acentuado que essa categoria não é suficiente para diferenciar os grupos familiares, segundo suas práticas escolares. A divisão em frações de classe seria muito abrangente para poder captar as diferenças entre as famílias. Outros estudos já apontaram que certas atitudes em relação à educação dos filhos variam menos com relação à classe social, do que com outros fatores, por exemplo: a trajetória ascendente ou descendente do grupo familiar, o nível educacional, o meio rural ou urbano e a postura mais ou menos conservadora e religiosa das famílias. Além disso, outros autores acentuaram que o conteúdo escolar não pode globalmente ser definido como sendo um arbitrário cultural dominante. Boa parte do conhecimento veiculado pela escola seria epistemologicamente válido e merecedor de ser transmitido. 
Nos anos 70, o referencial reprodutivista expressou a expectativa de verem banidas as desigualdades sociais através da educação, sob o pressuposto de que esta deveria ser garantida a toda população por intermédio da ação do Estado.

$\mathrm{Na}$ década de 80, a partir dos escritos de Antonio Gramsci, alguns ensaios teóricos trouxeram a formulação de uma pedagogia crítico-social dos conteúdos, pressupondo que a prioridade da escola seria contribuir para a formação de uma consciência de classe das massas. A função da escola seria alterar este estatuto. A crítica com relação a essa visão, apesar de ela ser uma alternativa ao reprodutivismo, é que ela subentende que o destino social e educacional do indivíduo está sobredeterminado por sua classe social. Essa visão traz contribuições importantes ao lançar luz à realidade de fato existente, mas ela é incapaz de dar conta da totalidade e compreender as trajetórias que rompem com a lógica da reprodução (D’ÀVILA, 1998).

Apesar de teorias da reprodução terem tido um papel fundamental na compreensão das desigualdades sociais, não houve um interesse suficiente ao que se passa no seio da família, em suas ações e significados com relação ao universo escolar. A questão da singularidade era um problema ainda não resolvido (NOGUEIRA, 1998; ZAGO, 1998).

Foi somente nos anos 80 e 90 que ocorreu um redirecionamento das pesquisas, havendo uma transição de uma sociologia das desigualdades da educação para as práticas pedagógicas cotidianas. Nessa nova perspectiva, o instrumento antropológico passou a contribuir muito através de estudos etnográficos, observação participante e também do ponto de vista histórico, através das histórias de vida e biografias escolares (NOGUEIRA, 1998).

Os pesquisadores voltaram-se, então, para processos e interações que ocorrem dentro da escola e da família, buscando definir a especificidade de cada grupo, sua dinâmica interna e sua maneira de se relacionar com o meio social. Essa abordagem trouxe uma visão multidisciplinar da sociologia, antropologia e psicologia social, onde os sujeitos são colocados enquanto atores sociais, participantes do processo de produção da realidade.

Nessa perspectiva, as famílias não podem ser consideradas em termos genéricos, mas de forma concreta e socialmente situada. Para que se compreendam as famílias das camadas populares é importante que se abandone os conceitos normativos e esquemas universais, como por exemplo: desorganização familiar, que introduz o estereótipo de 
que essa família é responsável pelo fracasso moral e educacional de seus membros. Assim, não se pode partir de modelos familiares superiores ou culturalmente mais civilizados ou mais sadios do ponto de vista psicológico. Existe um enorme leque de práticas de organizações domésticas e sociais que se constituem a partir das formas culturais e do contexto em que acontecem. Para que se compreenda o social é importante que se questione as concepções universais e que se pense o tema em termos de processos e contextos, ao invés de problemas isolados (ZAGO, 1998).

Sigolo e Lollato (2001) fazem uma crítica a algumas pesquisas realizadas a partir da década de 80 , que se dedicaram somente às análises macroscópicas e relações estatísticas entre a posição social dos pais e desempenho dos filhos, ou somente estudaram as práticas socializatórias internas ao microcosmo familiar.

Carvalho (2000) também traz um questionamento sobre a maneira como o tema família-escola tem sido estudado. Ela cita vários trabalhos que apontam ser o sucesso escolar dependente do apoio da família, que ajuda os filhos, compensando suas dificuldades e também as deficiências da escola. Ora, essa prática ocorre, predominantemente, em famílias com recursos econômicos e culturais, que têm tempo e escolarização suficientes para ajudar os filhos. De qualquer forma, as escolas, no geral, têm cobrado da família dois tipos de participação: primeiro, construindo o currículo e buscando afinidade cultural (quando necessário, a família deve passar para a escola seus hábitos e capital cultural). Uma outra maneira é através do dever de casa, onde são exigidos a participação e o apoio dos pais.

Assim, a partir de algumas pesquisas realizadas tanto nos Estados Unidos ${ }^{3}$ como no Brasil na década de 80 , a responsabilidade da família pelo sucesso dos filhos na escola passou a ser explícita e compulsória. Criticando essa concepção, a autora ressalta que o envolvimento dos pais não é uma variável que possa ser isolada e medida ou, de maneira conclusiva, ser apontada como fundamental para o aproveitamento escolar. Esse argumento é claramente ideológico e passou a ser aceito unanimemente dentro dos contextos educacionais, sendo endossado como um aspecto fundamental da escolarização bem sucedida.

Dentro dessa visão hegemônica, a política do dever de casa vem redefinindo a casa como uma extensão da sala de aula, sendo esta uma tarefa que deve ser realizada

\footnotetext{
${ }^{3}$ A retórica liberal do Banco Mundial está vendendo aqui a idéia da necessidade do apoio dos pais e da comunidade, bem como da maior freqüencia dos deveres de casa, como fatores determinantes da eficácia escolar (CARVALHO, 2000).
} 
fora do horário escolar. Alguns pesquisadores brasileiros, atrelados a essa política, estão também reproduzindo sua lógica. Vários estudos constatam os limites das famílias brasileiras quanto ao envolvimento na vida escolar dos filhos e recomendam a valorização da participação dos pais. Outros recomendam maior comunicação da escola com os pais e extensão do período de estudo via lição de casa. Outras pesquisas têm ressaltado o nível de escolaridade da mãe como determinante no desempenho escolar do aluno (CARVALHO, 2000).

Assim, partindo dos Estados Unidos e importada pelo Brasil, a fórmula "relação família-escola" acontece da seguinte maneira: mais envolvimento dos pais em casa, o que proporcionaria um maior aproveitamento e permanência na escola por parte dos alunos. Isso resultaria, ainda, em melhores escolas.

Um dos efeitos dessa política no Brasil é que a educação formal e a informal vão se distinguindo cada vez menos, e o papel materno e paterno vai se confundindo com o papel docente. Além disso, esse pressuposto está baseado num desconhecimento das mudanças nas formas de organização familiar, e corresponder ao modelo que vem sendo pedido de colaboração das mães com a escola se torna discrepante com a realidade atual. Os pais, ao serem obrigados a conduzir a educação formal, ficam prejudicados no tempo de lazer e de descanso e de relação informal e prazerosa com os filhos.

Ainda segundo Carvalho (2000), existem também conseqüências antidemocráticas dessa política. Quando os pais são obrigados a lidar com a educação formal, sem que sejam consideradas as diferenças de capital econômico, social e cultural entre os diversos grupos sociais, essa política poderá acentuar

[...] as desigualdades de aprendizagem escolar, culpando perversamente os pais e mães pelo fracasso escolar e, ao mesmo tempo, ao sobrepor o currículo escolar às práticas educativas domésticas e ao privilegiar um estilo particular de exercício da paternidade e maternidade, poderá enfraquecer a autonomia da família e a liberdade de pais e mães. Poderá ainda, ameaçar a pluralidade cultural ao impor a uniformidade cultural para além dos muros da escola pública, penetrando no reduto da vida privada (CARVALHO, 2000, p. 150).

O modelo bem sucedido de escolarização das classes médias pressupõe a participação familiar e a forma patriarcal de organização familiar, porque nessa classe social a família tem muito mais condição de contribuir com a vida escolar do fillho. Na medida em que essa política se amplia para todas as classes, essa ação se torna explicitamente totalitária. Isso porque a cultura dita científica e a visão de mundo 
dominante vão sendo impostas às culturas familiares no cotidiano doméstico e comunitário. A família vai sendo transformada a partir do ponto de vista da escola, e o saber da escola mais uma vez domina o saber popular cotidiano. É importante que sejam mantidos o pluralismo cultural e a liberdade da família para escolher a maneira de educar um filho (CARVALHO, 2000).

Além disso, nas camadas populares, a imposição do dever de casa acaba comprometendo a vida doméstica e aumentando os conflitos, uma vez que a mãe tem que ensinar o filho, tem que acompanhá-lo, fazendo paralelamente uma outra função, que corresponde aos cuidados da casa.

Uma outra implicação perversa dessa política é que a avaliação do aluno passa a corresponder à avaliação do desempenho dos pais, uma vez que a escola está exigindo seu apoio. A responsabilidade pela aprendizagem da criança aumenta o peso sobre a família, e o foco se desvia da escola e do trabalho da sala de aula.

Alguns autores (CARVALHO, 2000; CARVALHO \& VIANNA, 1994) afirmam que faz diferença planejar e desenvolver o currículo e as atividades escolares, bem como o tempo e a dinâmica da sala de aula com ou sem o dever de casa. Ou seja, na medida em que o foco se desloca para os pais, o trabalho da escola pode perder seu caráter prioritário.

Por outro lado, dentro de uma visão progressista da educação, alguns estudos apontaram a importância da participação dos pais na escola como uma estratégia para aumentar sua participação com relação a gestão escolar e decisões curriculares. Nessa visão, a relação entre a família e a escola traria ganhos para a família, relativos à possibilidade de ter maior acesso e controle dentro da escola pública; e para a escola, uma vez que ela poderia se tornar mais eficaz para os estudantes e para sociedade, tendo como base uma construção mais democrática (SAMARTINI, 1995).

A partir da explanação teórica sobre como o tema relação família-escola vem sendo abordado na literatura, será especificado o referencial teórico do atual estudo, com o objetivo de delimitar o objeto da pesquisa e o enfoque através do qual será feita a leitura da realidade. 


\section{2- O Sociodrama Educacional}

O Sociodrama Educacional corresponde a um grupo de pesquisa em Psicologia Escolar, coordenado pelo Professor Doutor Antônio dos Santos Andrade, docente da Faculdade de Filosofia, Ciência e Letras de Ribeirão Preto - Universidade de São Paulo.

O objetivo do grupo é buscar compreender as interações sociais que ocorrem no cotidiano das instituições escolares, com base na concepção de papéis como estruturas, conceito definido por Andrade (2004) como uma Totalidade Dialética, compreendida em dois sentidos: o primeiro aponta para a maneira "através da qual a estrutura social ou cultural se impõe ao indivíduo, mas que também traz os sinais da busca de sua negação e superação" (p.4). O segundo indica que os papéis não se revelam apenas nas representações que os indivíduos deles constróem, mas precisam ser investigados tais como são vividos, antes que conhecidos.

Parte-se ainda do pressuposto de que o homem se constitui numa matriz social e, ao mesmo tempo, contra ela. Acredita-se que é por meio do confronto entre o sujeito espontâneo e a estrutura social cristalizada que surge o sujeito criador, transformador da realidade.

Para uma maior compreensão desses conceitos, é necessário que se faça um recorte teórico sobre o referencial do Psicodrama, especialmente com vistas à definição do conceito de papel, não tomando somente o enfoque moreniano, mas trazendo a revisão do conceito realizada por Naffah Neto.

Uma outra teoria importante para essa compreensão das estruturas dos papéis, no sentido utilizado nas pesquisas em Sociodrama Educacional, é a Análise Institucional, de Georges Lapassade, que também será brevemente explanada nesta seção.

Em seguida, buscar-se-á, com base em uma revisão de como as representações vêm sendo entendidas por diferentes autores, apontar a definição que melhor contemple o objeto do atual estudo, aquela que englobe tanto a dimensão do conhecido, ou representado, quanto a dimensão do vivido.

\section{1 - O Psicodrama}

A abordagem moreniana, mais conhecida como Psicodrama, foi também denominada pelo próprio Jacob Levy Moreno de Socionomia. Esse termo traduz a tentativa de construção de uma nova teoria sociológica, ou microssociológica, já que 
Moreno (1992) visava explorar as leis do desenvolvimento social e das relações sociais. Naffah Neto (1997, p.129), ao fazer uma revisão crítica da obra moreniana, coloca que:

[...] a socionomia surgiu como algo mais que uma simples teoria sociológica, pois se propunha como uma revisão de antigas correntes e visava transportar suas complexas elaborações teóricas para o nível da realidade vivida no cotidiano, perseguindo no presente e por meio de investigações diretas o complexo estrutural dos intercâmbios das interações humanas, tal como se realizava, se cristalizava ou se transformava na realidade concreta e como esta era vivida e produzida por cada sujeito humano.

Esse projeto socionômico ficou também conhecido como microssociologia, uma vez que visava conhecer o fenômeno social, sua estrutura e sua dinâmica, como se o olhasse através de um microscópio. Moreno (1992) buscava uma compreensão do campo social partindo de seu interior, ou seja, estudando os átomos sociais e a maneira como estes se interligavam formando redes sociais.

Como ele estava interessado nas situações presentes e concretas, visando uma intervenção no sentido de transformação social, utilizou métodos experimentais. Dessa forma, a socionomia, em seu projeto de desenvolvimento teórico e prático, se ramificou em três grandes campos de estudo: a Sociometria, a Sociodinâmica e a Sociatria.

A Sociometria é o estudo das relações interpessoais, com vistas ao desvelamento da estrutura latente dos grupos, ou seja, de seu modo de funcionamento e sua organização psicossocial. Segundo Moreno (1992), "a teoria das relações interpessoais baseia-se na díade primária, a idéia e experiência do encontro de dois atores, o evento concreto-situacional preliminar a todas as relações interpessoais.” (p. 168) Vale ressaltar que o "encontro" entre dois atores é objeto de estudo da Sociometria, somente se considerado em seu caráter bilateral. Esse autor propõe ainda que "podemos discernir padrão de atração, repulsa e indiferença no limite entre indivíduos e grupos" (MORENO, 1992, p. 173). Esses padrões formam uma configuração dinâmica dentro de cada grupo (desde os menores agrupamentos, até as comunidades e a sociedade como um todo). A aspiração da sociometria é, portanto, identificar os padrões de relacionamento que compõem uma configuração grupal, definir sua estrutura, para que se possa compreender seu modus operandi. 
A Sociodinâmica é chamada também de Teoria dos Papéis. Essa teoria é fundamental para o entendimento da visão moreniana sobre o desenvolvimento sóciopsíquico do indivíduo, inserido em sua matriz de identidade ${ }^{4}$.

O primeiro padrão de interação e de conhecimento do mundo pela criança se dá dentro da família, que orienta o seu vir a ser de acordo com papéis sociais cristalizados (por exemplo: papel de pai, de mãe e até de filho, uma vez que antes do nascimento deste já existe uma expectativa quanto ao seu desempenho). Assim, a continuidade dos padrões sociais é transmitida desde a primeira infância, através das relações complementares entre papéis e contra-papéis.

Quando o bebê nasce, e enquanto estiver num estado de indiferenciação (ou préegóico), desempenha somente papéis psicossomáticos. Os papéis psicossomáticos são aqueles que definem as funções biológicas da espécie, como comer, dormir, urinar, e mesmo os mais instintivos, como mamar, dependem de um certo grau de improvisação e espontaneidade, como observou Moreno (1984). A partir do funcionamento desses papéis, surgem as primeiras formas de relação da criança com seu meio ambiente, o que dará origem a uma consciência (corporal nesse momento), a qual inicia a formação da identidade da criança.

Quando a experiência infantil de um mundo em que tudo é real começa a cindirse entre fantasia e realidade, surgem então os Papéis Sociais (reais) e os Papéis Psicodramáticos (que na infância correspondem aos papéis imaginários) ${ }^{5}$.

Papel, ou rôle em Francês (role em Inglês, rol em castelhano), significa "aquilo que deve recitar um ator numa peça de teatro", ou seja, uma função legitimada e de atuação restringida por uma ordem. A partir do século XI, esse termo foi empregado também no sentido de "função social, profissão". Observa-se que esse sentido da palavra papel já indica sua inserção na ordem social e sua função de manutenção da conserva cultural ${ }^{6}$.

\footnotetext{
${ }^{4}$ Esse termo diz respeito à família ou às instituições sociais que são co-construtoras da identidade do indivíduo, ao mesmo tempo em que ele também as (re)constrói.

${ }^{5}$ Naffah Neto (1997) faz a revisão desses conceitos, propondo que os papéis sociais são aqueles prescritos pela coletividade, produtos da conserva cultural, propostos sempre com um certo grau de rigidez. Aos papéis decorrentes do espaço da fantasia, que se configuram a partir da brecha, ele chama de Papéis Imaginários. Já os Papéis Psicodramáticos incluem criação pessoal, flexibilidade e liberdade. Segundo esse autor, o papel psicodramático "deve designar, necessariamente, a emergência de uma nova síntese entre imaginação e ação, entre espírito e corpo; justamente a retomada do sujeito como existência una e a dissolução de sua clivagem anterior em papel social e pessoa privada" (p. 211-12).

${ }^{6}$ Termo utilizado por Moreno (1984) para designar os padrões sócio-culturais cristalizados e mantidos "a todo custo" no cerne da sociedade.
} 
Os papéis sociais emergem, então, como reflexo de uma estrutura social rígida que se impõe por meio das instituições sociais vigentes, as quais constituem as matrizes de identidade dos indivíduos.

Moreno (1984), quando iniciou suas investigações no teatro, observou um conflito primário no ator entre o seu papel dramático e a sua pessoa privada. Mais tarde observou esse conflito em suas pesquisas com grupos: essa oposição, no nível sociométrico, se estabelecia entre a organização oficial do grupo e suas organizações espontâneas. No nível individual, ele observou um conflito entre interesses coletivos e privados, o que provocava muitas vezes uma cisão interna no indivíduo. Surge daí, o que Moreno chamou mais tarde de conflito entre papel e pessoa, que é o cerne mesmo da dialética presente na constituição do indivíduo social.

Por fim, a Sociatria trata da visão moreniana sobre (sócio)psicopatologia e traz em seu bojo propostas de intervenção. Naffah Neto (1997, p.215) traz uma contribuição importante na definição do conceito de saúde-doença dentro dessa abordagem:

São é o indivíduo espontâneo-criativo, capaz de relações télicas ${ }^{7}$, continuamente lançado no presente e podendo retomar e transformar suas formas de existir em relação a cada situação vivida; são é o indivíduo capaz de catalisar a imaginação com vistas à transformação da realidade, de retomar papéis sociais cristalizados e fixos que o circunscrevem e recriá-los, invertê-los, transformá-los na vivência das próprias relações em que se vê lançado; são, em síntese, é o indivíduo capaz de viver uma unidade entre o real e o imaginário, podendo fluir livremente entre essas duas dimensões, sem, contudo, fixar-se em nenhuma delas.

Os métodos de intervenção daí decorrentes são o Psicodrama, no qual o principal sujeito da intervenção é o indivíduo (visto a partir dos seus papéis e relações), e o Sociodrama, cujo fim é explorar os grupos como unidades a serem investigadas e "tratadas" (esse termo tem o sentido de transformação social). Um grupo é uma microunidade social que representa a sociedade como um todo, ou seja, poderia ser considerado uma célula, enquanto a sociedade é o organismo. Moreno (1992) propõe uma "revolução" (leia-se transformação) social através de um trabalho que favoreça a espontaneidade das micro-estruturas que são os grupos, com vistas a liberar sua

\footnotetext{
${ }^{7}$ Tele foi definida por Moreno como "uma ligação elementar que pode existir tanto entre indivíduos como, também, entre indivíduos e objetos e que, no homem, progressivamente, desde o nascimento, desenvolve o sentido das relações interpessoais (sociais). (...) Repousa no sentimento e conhecimento da situação real das outras pessoas. (...) Tele existe sempre e, normalmente, desde o primeiro encontro (...) Pode, por vezes, ser deformada pela influência de fantasias transferenciais. Mas, habitualmente, cada relação humana sadia depende da presença e eficácia da Tele" (MORENO, 1993, p. 45-6).
} 
criatividade, no sentido de auto criação (restauração do poder (re)criador da vida em sociedade).

O foco do Sociodrama é, portanto, os grupos sociais, como por exemplo aqueles formados por indivíduos que pertencem a uma mesma instituição, ou aqueles em que os indivíduos possuem um papel comum. Esse método instrumentaliza, além de uma leitura das relações intragrupais, também uma intervenção com vistas à transformação dos papéis cristalizados (não-espontâneos) e ao desvelamento da ideologia que faz com que os indivíduos atuem inconscientemente (repetindo padrões).

Naffah Neto (1997) sugere que "é na alienação do drama coletivo e na consolidação dos papéis sociais, que os atores desempenham, como marionetes, uma peça que não foi por eles escrita"(p. 202). Esse autor propõe que o cientista social atue no "sistema de posições e papéis oficiais" e que nesta ordem disciplinar ele deve implementar sua ação; "nesta redefinição consciente, se exigirá a participação de cada um e de todos, dar-se-á corpo a uma utopia científica: criar uma vida social fundada na dialética indivíduo-grupo" (p.147). Ele ainda sugere a regra da co-ação do pesquisador com o grupo, a regra da participação universal na ação, acrescentando que essas práticas remontam o método socrático: "a verdade e o caminho a serem seguidos jazem no âmago da própria experiência vivida pelo grupo e só por um processo gradual de conscientização e abertura a sua realidade de vida é que podem emergir" (p.142).

Diante dessa explanação teórica, pode-se dizer que a abordagem psicodramática foi utilizada como um dos referenciais teórico-metodológicos que embasam o atual estudo, uma vez que traz, mais especificamente, as seguintes contribuições:

- possibilita uma análise das relações interpessoais do cotidiano da instituição escolar,

- traz um método teórico-prático de condução grupal,

- possui uma teoria (sociometria) que se constitui num instrumento de análise dos dados provenientes de sessões grupais.

\section{2 - A Análise Institucional}

A Psicologia Institucional enfoca o plano ideológico presentificado nas representações dos atores institucionais visando, assim, o entendimento das relações concretas que acontecem na instituição, as práticas de dominação e resistência e os jogos imaginários que investem as relações instituídas/instituintes no âmbito escolar. 
Parte-se do pressuposto de que só se pode apreender uma instituição através das relações sociais específicas que a fundam, do conjunto de práticas conflitantes ou divergentes e ora complementares, que acontecem entre seus atores concretos. No caso da escola pública os atores institucionais são: o Estado como mandante, os professores como agentes privilegiados, os estagiários, os auxiliares de ensino e os substitutos como agentes subordinados, a clientela (alunos) e o público (as famílias e a população em geral). "A prática institucional seria resultante do confronto entre esses vários atores ou, antes, entre as diferentes posições e lugares por eles ocupados num dado cenário institucional" (AQUINO, 1996, p.18).

Segundo Guirado (1987), o foco da psicologia institucional é o entendimento das relações, não as relações materialmente dadas, mas sim as relações tais como imaginadas, percebidas e representadas pelo sujeito. Essa autora define a Análise Institucional, de Georges Lapassade, como uma maneira singular de se compreender as relações instituídas e, também, como uma forma de intervenção que visa à transformação da instituição, a partir da revelação de sua estrutura.

Dentro dessa abordagem, a realidade social é vista como acontecendo em três níveis: o grupo, a organização e a instituição.

Toda relação social se faz, sempre, nos grupos. Estes, por sua vez, podem vir a configurar organizações e são, ambos, sobredeterminados pelas instituições.(...) Instituição, nessa abordagem, é o conjunto do que está instituído e, enquanto jurisdição e política, pauta toda e qualquer relação" (GUIRADO, 1987, p. 28-9, grifo da autora).

Observa-se aqui um distanciamento do conceito marxista de instituição. A experiência cotidiana é vista como estando aprisionada num sistema institucional que sobredetermina o que se passa nos grupos e organizações.

Para Lapassade (in GUIRADO, 1987) a ideologia é um mecanismo coletivo de repressão, não uma simples ignorância dos modos de funcionamento da sociedade pelos seus membros. É um "desconhecimento do sentido estrutural de seus atos, do que determina suas opções, suas preferências, suas rejeições, opiniões e aspirações, pela ação do Estado, através das mediações institucionais que penetram em toda a sociedade" (Lapassade, 1977, apud GUIRADO, 1987, p.32). Assim, o Estado é a instituição por excelência, enquanto sistema de normas e padrões culturais hegemônicos; é a lei e, por ela, a repressão. 
$\mathrm{Na}$ vida social, criada pelo Estado, a burocracia desempenha um papel fundamental, sendo um tipo de "organização do poder, em que há uma alienação da condição de decisão sobre o fazer cotidiano em favor de grupos (ou dirigentes) que, embora em relação, não alinham seus interesses aos dos grupos ou indivíduos executores" (GUIRADO, 1987, p. 35). Assim, a inserção de sujeitos e grupos nos procedimentos burocráticos faz com que o cotidiano seja a forma singular das instituições sociais. A ordem burocrática é, ainda, a dimensão oculta que determina o que se dá ao nível dos grupos e organizações. Quanto maior a fidelidade a ela, maior a conformação ao Estado e suas leis. Em oposição ao conceito de burocracia, tem-se o conceito de autogestão, que é a maneira pela qual o que acontece no cotidiano retoma seu sentido original.

Guirado (1987) coloca ainda que, enquanto intervenção, diferentemente da análise organizacional, a Análise Institucional de Lapassade

[...] propõe-se ser a condição concreta para que se revele a determinação institucional, oculta pela repressão do sentido e pelo encobrimento ideológico. Provocando o grupo a falar e atuar, promove-se a análise da situação e desvendam-se as instituições determinantes do discurso e da ação grupal (GUIRADO, 1987, p. 41).

Dentro dessa visão, a Estrutura de Papel pode ser mais bem compreendida, já que ela se constitui na dialética instituído-instituinte no interior dos grupos, organizações e instituições que compõem a escola. Andrade (2004) afirma ainda que esse conceito é constituído por "componentes cristalizados ou normativos, internalizados em um processo de identificação como grupo instituído (...) Mas, também, por componentes de resistência, que resultariam do movimento dialético no sentido de superação da imposição social dos papéis" (p.5).

\section{3- O conceito de Representação}

O termo representação vem sendo utilizado por diversos autores, cada qual destacando alguma especificidade, própria de seu campo de estudo. Numa perspectiva sociológica, Xavier (2002) coloca que Durkheim, ao abordar as representações coletivas, traçou uma linha rígida entre o individual e o coletivo, apontando uma prevalência do segundo sobre o primeiro. As críticas que a autora faz a essa teoria são 
no sentido de uma não consideração do plano simbólico no indivíduo e dos conflitos presentes na socialização e internalização de valores sociais.

Por outro lado, numa abordagem psicanalítica, como a descrita por Laplanche \& Pontalis (1986), o termo é utilizado numa perspectiva intrapessoal, como "aquilo que se representa, o que forma conteúdo concreto de um ato de pensamento e em especial a reprodução de uma percepção anterior" (p.582). Observa-se aqui uma sobredeterminação dos processos cognitivos em detrimento dos fatores sociais e interpessoais.

Um avanço com relação a essas teorias de cunho exclusivamente sociológico ou psicológico é a teoria psicossocial de Serge Moscovici. Segundo Xavier (2002), Moscovici apropriou-se do conceito durkheimiano, modificando-o e iniciando uma nova corrente de pesquisas sobre representações sociais. Para tanto, o autor retirou do conceito o peso da ontologia social (de Durkheim) e deu a ele uma consistência cognitiva acentuada, situando-o a meio caminho entre o social e o psicológico. Além disso, ele delimitou o campo de ação das representações sociais, que é o cotidiano, e "especificou a representação como uma forma de conhecimento particular, relacionado com o senso comum, com a interação social e com a socialização". (Perrusi, 1995, apud XAVIER, 2002)

Tanto Moscovici (1978) quanto Sá (1996) ressaltam o quanto o termo traz em seu bojo uma grande complexidade, não podendo ser explicado levianamente, ou por meio de uma única perspectiva. Várias são as suas conceituações, a saber: a representação é, ao mesmo tempo, uma construção do sujeito, do ponto de vista cognitivo e psicodinâmico, e também é construção social ou coletiva.

Segundo Sá (1996), a teoria das representações sociais é um amplo campo de estudos psicossociológicos porque engloba tanto fenômenos quanto conceitos, sendo sua estrutura constituída por três aspectos: a informação, ou seja, a maneira como um grupo organiza seus conhecimentos sobre um objeto social; o campo de representação, ou as proposições acerca desse objeto; e a atitude, que constitui a orientação global ou a maneira como se lida com esse objeto.

No mesmo sentido, Jodelet (1989 apud SÁ, 1996) coloca que a representação social é "uma forma de conhecimento, socialmente elaborada e partilhada, que tem um objetivo prático e concorre para a construção de uma realidade comum a um conjunto social” (p.32). A representação social é, então, um saber prático que liga um sujeito a um objeto, a partir de uma relação de simbolização e interpretação. 
Moscovici (1978) coloca ainda que existe um metassistema cujo fim são as regulações sociais. Esse metassistema controla e dirige as aspirações cognitivas. As representações sociais seriam, então, a análise das regulações do metassistema sobre o aparelho cognitivo individual. Esse autor aponta, ainda, que essas regulações são uma modalidade de conhecimento que tem por função exclusiva a elaboração de comportamentos e a comunicação entre indivíduos.

Moscovici (1978) caracteriza as representações sociais também de uma outra maneira: como transformação do objeto estranho em algo familiar, "quando precisamos sua natureza de processo psíquico, capaz de tornar familiar, situar e tornar presente em nosso universo interior o que se encontra a uma certa distância de nós, o que está, de certo modo, ausente" (p. 62). Assim, ocorre uma apropriação subjetiva do mundo, embora esta seja percebida como uma presença objetiva da realidade.

Apesar das tentativas de abarcar toda a complexidade do conceito, de acordo com Xavier (2002), Moscovici deixa algumas lacunas em sua abordagem de representação social: uma negligência quanto ao âmbito do poder e das hierarquias sociais, sendo seu conceito de "social" desprovido da diversidade das interações sociais. Além disso, a autora acusa que os conflitos sociais, inter e intra-grupais, não são considerados na análise do processo de constituição das representações sociais. A autora ainda destaca que "ao arcabouço psicossocial de Moscovici, porém faltaria acrescentar as tais pertenças sociais, uma localização histórica e política, isto é, a dimensão sociológica" (p.10).

Doise (1990, apud SÁ, 1996) complementa essa visão, acrescentando que as inserções e situações sociais são diversas do ponto de vista social e, a nível individual, são múltiplos os processos que intervém na tomada de posição. Isso resulta, então, numa multiplicidade aparente de tomadas de posição individuais que são organizadas a partir de organizadores comuns. O consenso não é, portanto, uma característica essencial das representações sociais. Esse autor define as representações sociais, privilegiando uma análise posicional e ideológica. "Representações sociais são princípios geradores de tomadas de posição ligadas a inserções específicas em um conjunto de relações sociais e que organizam os processos simbólicos que intervém nessas relações” (p. 33).

Xavier (2002) acrescenta ainda o conceito de ideologia, de Althusser e o de hegemonia de Gramsci como fundamentais para uma compreensão mais abrangente das representações sociais. Sua justificativa é que na teoria das representações sociais, quando se fala em contexto, faz-se referência somente à situação de interação, daí a 
necessidade de outras teorias que preencham essa lacuna. Quanto à ideologia, a autora destaca que ela é um sistema de idéias capazes de inspirar atitudes concretas e orientar ações. Portanto, a ideologia hegemônica, dominante, tem o potencial de propagar uma visão de mundo aparentemente mais coerente e sistemática, influenciando a massa da população, organizando dessa forma as instituições sociais. Esse seria o pano de fundo, ou estrutura, no qual se assentam as representações sociais.

Buscando articular esses três conceitos: representações sociais, ideologia e hegemonia, a autora retoma Moscovici, resgatando a definição dos processos de objetivação e ancoragem. A objetivação é por ele definida como o processo pelo qual os elementos abstratos constituintes da representação se materializam e formam expressões de uma realidade vista como natural. Já a ancoragem funciona como estabilizador do meio, sendo um mecanismo de cristalização dos objetos, gerando um conflito entre a manutenção e a mudança.

Xavier (2002) ressalta, ainda, que não se pode sempre determinar a gênese das representações, sendo que às vezes o máximo que se pode fazer é identificar como as representações, tais como utilizadas num determinado momento histórico, são ou podem ser postas a serviço de uma ideologia ou luta hegemônica.

Nessa conceituação estão presentes, assim, três aspectos: as representações sem funcionalidade social prática atual, as representações ligadas às noções de ordem e organização social e as percepções sobre o posicionamento dos indivíduos na organização. A autora sugere, assim, que se pense as representações sociais em termos de matéria comunicativa do cotidiano, incluindo aspectos do senso comum, ciência, comunicação de massa, que ao entrarem na esfera pública assumem uma nova dimensão.

Portanto, assim como no cotidiano, as representações teriam caráter performativo (orientação das ações e organização do real), ao entrarem no campo político esse caráter performativo assume o sentido althusseriano (repercussão na ação e no pocisionamento dos sujeitos na organização social). [...] Assim, ao pensar nas representações sociais do ponto de vista sociológico, há de se considerar a articulação entre o mundo vida e a esfera pública, contextualizando essas relações com o contexto presente e com os discursos presentes, situando-os na história e na cultura da formação social em questão (XAVIER, 2002, p. 34). 
Já Penin (1993, 1995), pesquisadora da área educacional, propõe em seu estudo ainda outra maneira de definir representação, buscando englobar no seu objeto de pesquisa, aspectos da realidade que fogem do campo de abrangência do conceito de representações sociais explanado anteriormente. Ela parte da visão dos autores anteriores, no sentido de considerar as regulações do metassistema sobre o aparelho cognitivo individual, mas busca compreender, também, de que maneira os sujeitos elaboram e reagem a essas representações, chamadas sociais.

Essa concepção está baseada na obra de Henri Lefebvre, La présence et l'absence - pour une teorie de la representation, onde esse autor reconstitui a discussão sobre representação na história da filosofia e chega a uma proposta conceitual. Segundo ele, para os filósofos pré-socráticos, representação era a opinião comum e, desde Platão até a modernidade, a filosofia tem buscado sair da opinião comum e atingir a verdade. Aristóteles propôs que as representações equivocadas deveriam ser superadas por meio da ciência, através dos conceitos. Nesse ponto, Lefebvre lembra que Aristóteles separou na história da filosofia, o concebido do vivido. Com Descartes, fundador do racionalismo moderno, o concebido ganhou a primazia e a vivência passou a se reduzir ao pensamento. No século XVIII, Kant, visando ultrapassar a oposição entre racionalismo e empirismo, introduziu o conceito de representação, sendo este nem a verdade, nem a falsidade, mas algo intermediário. Hegel retoma o entendimento de que representação é uma opinião, ou seja, o oposto da verdade. Para ele, a filosofia deveria atravessar a opinião, já que esta não apreende o movimento aparentemente contraditório do real. Para tanto, deve-se buscar o conceito e a idéia, pois tudo é representado, menos a idéia, a fonte. É o elemento de universalidade que se exprime no conceito e na idéia (Lefebvre, 1983, apud PENIN, 1995).

Lefebvre, assim como Hegel, aceita que a representação seja somente um nível de conhecimento, mas discorda de Hegel quanto à maneira de transcendê-lo. Para Hegel, essa superação acontece por meio do conhecimento pessoal, do exercício intelectual. Já Lefebvre afirma a necessidade de uma análise crítica sobre todas as experiências da vida cotidiana. Ele cita Marx e Nietzsche como tendo avançado nessa direção, ao proporem a saída das representações através da ação e da crítica radical (PENIN, 1995).

Lefebvre organiza sua teoria em função de duas idéias: primeira, a aceitação do representativo como um fato social, psíquico e político ou seja, ele existe, possui positividade, está presente na vida cotidiana, 
via representações sociais e pessoais e segunda, a recusa dessas mesmas representações, que só podem ser ultrapassadas com o exercício da crítica teórica e da ação (PENIN, 1995, p.21).

Dessa forma, segundo a autora, Lefebvre inaugura uma teoria do conhecimento que considera o não instituído e o não concebido, mas que é existente, é vivido.

Este espaço das representações preenche o que Lefebvre chama de momento da Ausência. Este é um momento de extrema importância, pois é nele que as várias concepções, presentes no imaginário ou representações sociais, e os elementos provenientes da vivência são contrapostos das mais diferentes formas. Ao tomar essas concepções e a vivência para uma análise crítica é que o sujeito organiza o seu "concebido" e o seu "vivido". [...] É na confluência do concebido e do vivido que as representações se formam.[...] Presença é o momento que realiza em ato o resultado da crítica sobre as representações. Este será um ato criativo e não repetitivo (PENIN, 1995, p. 22).

Tomamos, pois, o caminho sugerido por Penin na compreensão de representação, uma vez que o atual estudo se situa também dentro da área educacional, sendo os universos de pesquisa parecidos. Assim, o objeto de pesquisa se coloca na imbricação entre as representações advindas do meio social e aquelas provenientes da vivência pessoal dos indivíduos, sendo o objetivo investigar como as representações chegam até os indivíduos e como estes reagem a elas. Vale lembrar que segundo Penin (1995), é importante “alcançar as representações e, partir delas é o caminho possível para, com vontade e/ou estratégias adequadas, superá-las(...) Desvelá-las: eis a tarefa da investigação educacional” (p. 14).

\section{II- Contextualização sócio-histórica do tema}

\section{1 - Recorte histórico sobre a função social da escola}

Ariès (1978) faz um apanhado histórico da escola, desde a Idade Média até o século XIX, apontando a função do professor e da disciplina, mostrando de que maneira o desenvolvimento da escola contribuiu para a construção de uma certa visão da infância. Segundo ele, na Idade Média as escolas aconteciam na Catedral, e a educação se assemelhava à cultura, porque poderia acontecer durante toda extensão da vida humana. $\mathrm{O}$ ensino não visava o cerceamento do aluno e a disciplina era conseguida através da convivência grupal em comunidade, mais do que pela imposição do 
professor. O professor ensinava no claustro, dentro ou na porta da igreja, ou ainda numa esquina de rua. Mais adiante um pouco, ele passou a alugar uma sala, que era chamada de schola, por um preço que era regulamentado na cidade. Assim, o professor passou a se assemelhar a um comerciante e o estudante não estava submetido a uma autoridade disciplinar ou a uma hierarquia escolar.

Segundo Áries (1978), até o século XIII, os colégios eram asilos para estudantes pobres, e não tinham a função de instruir. A partir do século XV se tornaram institutos de ensino e, do século XV ao XVII, tornaram-se modelos das grandes instituições escolares, por exemplo, os colégios Jesuítas, Doutrinários, entre outros. Os estudantes, apesar de não estarem comprometidos por nenhum voto, ficavam submetidos ao modo de vida dessas comunidades. Nessa época, o colégio se abriu a um número crescente de leigos, nobres, burgueses e famílias populares; não era monopólio de uma classe social, mais sim de um gênero, uma vez que a escolarização feminina se iniciou somente no século XVIII.

Ariès (1978) ressalta, também, que foi somente a partir da metade do século XVI que começou a surgir uma idéia de educação na qual os mestres têm responsabilidade, no sentido de serem encarregados pelas almas dos alunos. Nessa época, a instrução passou a se identificar com formação, e o mestre passou a adaptar seu ensino ao nível do aluno.

Por fim, o estabelecimento de uma regra de disciplina completou a evolução da escola medieval, que era simples sala de aula, ao colégio moderno, instituição complexa, não apenas de ensino, mas de vigilância e enquadramento da juventude. Para salvar as almas das crianças, os mestres deveriam utilizar a correção e a punição. Os colégios tinham um governo autoritário e hierarquizado e um sistema disciplinar rigoroso, baseado na vigilância constante. Havia também a aplicação ampla de castigos corporais.

Ariès (1978) ainda coloca que foi ao longo do século XVIII, após a revolução cartesiana, que aconteceu a especialização social em dois tipos de ensino: um para o povo e outro para as camadas burguesas e aristocráticas. $\mathrm{O}$ ciclo escolar integral passou a ser, então, no mínimo de 4 ou 5 anos, havendo o liceu ou colégio, para os burgueses, caracterizado pelo ensino secundário de longo prazo; e a escola, de ensino primário e curto, para o povo. Apesar das idéias iluministas iniciais, que traziam a importância moral e social da educação, o que ocorreu nessa época foi o limite a uma única classe 
social, o privilégio do ensino longo e clássico. Ao povo foi destinado um ensino inferior, exclusivamente prático.

Na primeira metade do século XIX, com a demanda da mão-de-obra infantil na indústria têxtil, agravou-se o fato de as crianças das camadas populares serem submetidas por menos tempo à ação da escola. O trabalho, dessa forma, segundo Áries (1978), conservou uma característica da sociedade medieval, a precocidade da passagem da criança para a vida adulta. Com relação à disciplina, tratava-se, agora, de despertar na criança a responsabilidade do adulto, o sentido de sua dignidade. A criança deveria ser preparada, pela escola, para a vida adulta, o que exigia cuidados e etapas: uma formação.

Ainda no século XIX, o internato passou a ser a instituição escolar ideal, que obtinha os melhores resultados em termos de disciplina e vigilância. Nessa época, foi criado o ciclo anual das promoções e o hábito de impor a todos os alunos a grade completa de séries escolares. Surgiu, então, a necessidade de uma pedagogia nova, adaptada às classes menos numerosas e mais homogêneas.

\section{2 - As transformações na instituição familiar}

Observa-se atualmente, antes de tudo, uma vivência familiar pontuada por paradoxos, por vários sistemas de valores coexistindo, ao mesmo tempo em que os padrões de exigência e de qualidade aumentam, rumo à busca de uma maior realização pessoal e relacional.

Existe ainda um modelo de família que é imposto como o "correto", causando vários tipos de conflitos, uma vez que a impossibilidade de realizá-lo gera sentimentos de culpa e incapacidade. Além disso, ele é também utilizado quando a família não se insere no padrão, como por exemplo na justificativa do fracasso escolar dos filhos.

Assim, esse cenário deverá ser utilizado para contextualizar o discurso dos pais acerca da escola, uma vez que esses valores se difundem e determinam o modo de significar quaisquer experiências que tenham relação com a vivência familiar.

\section{1- Questões educacionais}

Segundo Ariès (1978), a organização familiar moderna tem suas origens no século XVI, com os valores impostos pelos juristas e reformadores, que ensinaram aos 
pais que eles eram guardiões espirituais, ou seja, responsáveis perante Deus, pela alma e pelo corpo de seus filhos. "A família deixou apenas de ser uma instituição do direito privado para transmissão dos bens em nome, e assumir uma função uma função moral e espiritual, passando a formar os corpos e almas" (ARIÈS, 1978, p.277).

Os pais passaram, então, a se interessar por todos os filhos, e a moral da época indicava a necessidade de proporcionar a todos eles (e não apenas para o mais velho) uma preparação para a vida. No fim do século XVII, até mesmo para com as meninas era importante essa preocupação. Ficou convencionado, então, que essa preparação fosse assegurada por uma instituição própria a esse fim, a escola. A aprendizagem tradicional foi transformada em um instrumento de disciplina severa e protegida pela justiça e pela política. Dessa forma, a família e a escola juntas retiraram a criança da sociedade dos adultos, passando a tratá-la com rigor, em nome de um amor obsessivo. No século XVIII, a família se reorganizou definitivamente em torno da criança, o que acarretou a cisão entre a família e a sociedade, através do muro da vida privada (ARIÈS, 1978).

Segundo Cunha (1998), no Brasil, particularmente na época colonial, o filho ocupava uma posição instrumental dentro da família. No século XIX, o trabalho dos médicos higienistas teve como objetivo justamente combater esse tipo de família, na qual a criança era menosprezada. Outro papel importante dos higienistas foi transformar o papel da mulher, antes um ser indiferenciado no interior do grupo familiar, agora com o papel de anfitriã e espelho da qualidade da família.

Os higienistas propagaram muitas idéias sobre a educação infantil, escrevendo um conjunto de normas disciplinadoras, por exemplo: impedir o ócio, impor exercícios físicos, desenvolver e fortalecer o espírito, a vigilância moral, controlar a sexualidade das crianças, entre outros. O ideário de família que se buscava construir foi o do homem que trabalha e mantém o sustento da família e da mulher, que se ocupa dos afazeres domésticos e dos cuidados com os filhos.

Já as famílias operárias tinham dificuldades em atender a essas prescrições. As condições da mulher para dar atenção aos filhos eram muito piores, tanto que a partir da década de 1920, o empresariado brasileiro começou a abandonar as práticas muito coercitivas e passou a utilizar um novo ideário de higienização da fábrica (movimento conhecido como domesticação do operariado). Assim, a vontade subjetiva do patrão passou a ser imposta como, por exemplo, na ênfase sobre as relações familiares, em que os modelos de mulher eram voltados para o lar, sendo este último um espaço de vida 
regrada e assexuada. Os trabalhadores foram, então, se habituando aos valores dominantes (CUNHA, 1998).

No início do século XX, o poder médico foi redefinindo o estatuto da criança, e a rua passou a ser vista como um perigo, onde proliferavam maus costumes e a decadência moral. Os menores abandonados passaram a ser assistidos por instituições apropriadas para esse fim, visando adquirir hábitos de disciplina e de trabalho. Outro fato importante foi que no final do século XIX os saberes científicos foram colocados em prol da normalização da vida familiar. Nesse contexto, a Psicologia, que vinha se organizando como Ciência, passou a ser portadora de “(...) vasto aparato de controle e intervenção sobre os acertos e desacertos praticados pelos pais” (CUNHA, 1998, p.31).

Cunha (1998) aponta, ainda, que com essa vigilância e esse modelo idealizado, as práticas maternas de cuidados com as crianças passaram a ser carregadas de ansiedade e o controle higiênico foi cercado de apreensão e rigor. A palavra de ordem era o autocontrole e o cerceamento dos prazeres físicos. Dessa forma, promoveu-se uma internalização de conflitos, havendo uma psicologização das relações entre pais e fillhos.

Antigamente, o filho tinha uma perspectiva de ganho financeiro para os pais, mas atualmente, pela proibição do trabalho infantil e a extensão do período de escolaridade obrigatório, o filho deixa de significar um investimento econômico e passa a ser valor enquanto garantia de descendência e objeto de afeto e preocupação. As famílias passam, então, a se preocupar muito com a inserção do filho na sociedade.

Vale notar que atualmente a possibilidade de ascensão social está diretamente associada ao sucesso escolar. O capital escolar legitima as posições dos jovens no espaço social, e a escola é a principal instância de legitimação individual e de distribuição dos atributos que determinam o valor dos indivíduos. $\mathrm{O}$ valor do filho passa a ser medido, em boa parte, pelo seu valor escolar.

Assim, as várias combinações familiares são permitidas desde que não comprometam a produtividade escolar e social dos filhos, pois o êxito dos filhos está intrinsecamente ligado ao êxito pessoal dos pais. Dessa forma, o fracasso escolar, muitas vezes, é sentido pelos pais como sua responsabilidade e é acompanhado de um sentimento de culpa. Conclui-se, dessa forma, que a educação formal ocupa um papel central na vida da família contemporânea (NOGUEIRA, 1998). 


\section{2 - Questões ideológicas}

Sendo a família uma estrutura social e não biológica, sua configuração está sempre sujeita às transformações ideológicas que acontecem na sociedade. Pode-se até dizer que, num movimento dialético, a família se transforma, transformando valores sociais, ao mesmo tempo em que os valores sociais também determinam e transformam o modo de ser da família.

Na sociedade brasileira, segundo Romanelli (1995), o modelo predominante é o da família nuclear, havendo uma hierarquização do poder, onde a mulher se subordina ao homem, e os filhos aos pais, havendo uma política autoritária de relacionamento. Além disso, observa-se a presença de vínculos afetivos entre os integrantes da família, o controle da sexualidade feminina e a dupla moral sexual. Vale ressaltar que esse padrão foi hegemônico até os anos 50, quando a família possuía um script de funcionamento bem definido, com os papéis de pais, filhos, marido e mulher estritamente delineados em torno do que é certo ou errado, havendo vários mecanismos para controlar as várias formas de desvio.

Desde a década de sessenta, aconteceram mudanças na sociedade ${ }^{8}$, e foram inseridos padrões inovadores (principalmente o igualitarismo) em alguns segmentos das camadas médias. Houve um questionamento dos valores hegemônicos que organizavam a moralidade sexual e a vida familiar, surgindo orientações culturais diversificadas.

Começaram a aflorar novas formas de expressão da afetividade e da sexualidade, havendo uma maior liberdade de conduta feminina. Além disso, passou-se a "valorizar a igualdade entre os sexos, a autonomia do sujeito diante do controle familiar, a maior liberdade na expressão afetiva e sexual que, de modo ambíguo e vacilante, contrapõe-se aos princípios sustentadores do modelo de família” (ROMANELLI, 1991, p.33).

Até os anos 20, a instituição casamento estava dissociada das relações de amor, sendo o casamento instituído a partir de interesses alheios ao casal.

\footnotetext{
${ }^{8} \mathrm{Na}$ década de 60 houve um modelo de desenvolvimento econômico que alargou a desigualdade na distribuição de renda, e a sociedade passou a oferecer produtos com alto valor simbólico, criando um maior desejo de consumo. Com isso, a mulher partiu para o mercado de trabalho, e os movimentos feministas ganharam força, denunciando a violência contra mulheres e crianças que ocorria no interior da família. Além disso, houve o boom da psicanálise, dando origem ao psicologismo, ou seja, à inserção na cultura de valores pseudo-científicos que ditavam novos conceitos acerca das pessoas e das relações familiares.
} 
Dos anos 20 aos anos 60, a família passa a ser regulada pelo amor, sendo o casamento valorizado como instância própria para sua ocorrência. Chamado de amor romântico, essa forma ideal de relacionamento implicava numa definição clara de papéis, sendo o homem responsável pela esfera pública, cabendo à mulher os cuidados com a família e com a manutenção do amor.

A partir das mudanças ocorridas nos anos 60, surgiu um novo ideal de família e de amor, cuja característica principal é a simetria e igualdade nas relações, só podendo ocorrer verdadeiramente quando homem e mulher abrem mão do domínio de um sobre o outro. Esse amor é chamado por Torres (2000) de amor-construção e tem como pressuposto básico a paridade entre os gêneros e uma proximidade entre eles no plano do desempenho dos papéis sociais (ainda que estejam presentes algumas assimetrias). Esse novo valor traz, em contrapartida, um aumento das expectativas em relação ao desejo de ser compreendido pelo outro, o que torna difícil um ajuste à realidade cotidiana, trazendo maiores desilusões, instabilidade e incerteza.

Estudos recentes apontam as mudanças reais ocorridas na família (PRADO, 1996; FREITAS, 1999; DIAS, 1995): aumento do trabalho assalariado de mulheres, diminuição do número de casamentos, diminuição das famílias numerosas, aumento no número de divórcios, aumento do número de famílias monoparentais, aumento do número de famílias recompostas.

No entanto, Singly (2000) coloca que a família atual não possui uma total ruptura com o modelo de família anterior, já que "a lógica do amor se impôs mais ainda: os cônjuges só ficam juntos sob a condição de se amarem; os pais devem ainda dar mais atenção aos seus filhos” (p.15). O que diferencia as duas famílias é a maior ênfase no processo de individualização, sendo que o elemento central não é mais o grupo reunido e sim os membros que o compõem.

Pode-se dizer que o processo de individualização baseia-se em dois eixos: autonomia e independência. O primeiro diz respeito a uma consolidação do eu, na criação de regras pessoais e, no caso de vida em comum, na negociação das regras entre as várias pessoas. A independência está mais relacionada à questão econômica e ao trabalho, implicando numa igualdade de poder. Singly (2000) chama esse tipo de relação de "individualista e relacional", uma vez que traz uma necessidade de autonomia dos sujeitos, além do desejo de viver em relação íntima e próxima com outras pessoas.

Assim, a família contemporânea pode ser considerada forte e frágil: 
[...] frágil, pois poucos casais conhecem antecipadamente a duração de sua existência, e forte porque a vida privada com uma ou várias pessoas próximas é desejada pela grande maioria das pessoas (sob certas condições, ou seja, se a família não é percebida como sufocante).(...) E é nessa tensão entre dois pólos que se constróem e se desfazem as famílias contemporâneas" (SINGLY, 2000, p.15).

Também Bilac (1995) considera que "esse modelo familiar reforça o individualismo tanto dos homens adultos, cujas necessidades e desejos passam a ser predominantes na relação conjugal, como também das crianças, que desde cedo se acostumam a ser o centro das atenções" (p. 57). Observa-se que o "fluxo de riqueza" se orienta no sentido dos pais para os filhos, sendo a grande tarefa da família a socialização competente das crianças.

Um outro aspecto importante que vem ocorrendo é a transformação da educação. "A educação familiar se transformou, depreciando a obediência e valorizando a iniciativa, a autonomia e a satisfação pessoal” (SINGLY, 2000, p. 18).

Com relação às questões de gênero, Torres (2000) observa que a mulher, ao trabalhar fora de casa, ganha um maior poder de decisão, uma maior amplitude de relações de sociabilidade, além de um maior reconhecimento de suas habilidades específicas. No entanto, com relação aos cuidados com os filhos, as mulheres ainda assumem maiores responsabilidades do que os homens. "É só nos setores jovens que os encargos com as crianças são mais repartidos entre os cônjuges” (p. 142).

Em pesquisa com jovens universitários, Torres (2000) observou que ambos os gêneros desejam uma profissão que os realize pessoalmente, mas com a vinda dos filhos, a mulher se vê obrigada a diminuir o ritmo de crescimento profissional. Ela aponta a seguinte questão: "Dos homens espera-se que sejam indivíduos sem família, às mulheres exige-se que a família se sobreponha à profissão" (p.143). E completa: “Talvez seja tempo de perceber que o que precisa ser superado é precisamente essa contradição, esse efeito diferencial de gênero" (p.143).

$\mathrm{Na}$ verdade, essas mulheres vão descobrir alguns constrangimentos inerentes à sua condição de mulheres com a vinda do primeiro filho, porque, mesmo que os homens hoje tendam a partilhar os cuidados com os filhos e a desejar fazê-lo, "já no plano das tarefas domésticas as assimetrias são evidentes" (p.144). Torres (2000) conclui que "no caso feminino, os projetos mais individualizados estão sempre condicionados à harmonização com a vida familiar, enquanto os masculinos tendem a ser formulados de forma independente desta" (p.144). Mesmo assim, a mulher se coloca menos como 
vítima das circunstâncias, tendo uma visão mais clara de sua existência, mostrando vontade de que as questões ainda pendentes sejam vencidas.

Vale notar que a modernidade cultural influenciou a organização familiar de maneira mais visível no interior de um segmento social jovem, com escolaridade superior e maior acesso às novas concepções. No entanto, ao mesmo tempo em que o modelo anterior já não contava com adesão irrestrita, as novas concepções traziam um modelo ainda incipiente. Dessa forma, houve uma desestabilização e um conflito potencial no interior da família.

Figueira (1987) ressalta que "tudo só muda rapidamente na superfície, que o novo e o moderno convivem com o arcaico e antiquado" (p.13). Ele aponta que a noção de desvio de comportamento perde sua clareza, havendo uma pluralidade de escolhas, limitadas pelo respeito à individualidade do outro. Essas questões se dão no plano do novo ideal igualitário, mas a realidade da família modernizada é bem mais ambígua, exatamente por não ser linear e contar com outras dificuldades relativas à absorção de novos sistemas simbólicos pelo sujeito.

Nicolaci-da-Costa (1985) aponta que essa questão promove uma descontinuidade socializatória no sujeito, ou seja, uma internalização de sistemas simbólicos conflitantes. Essa autora mostra que as maiores críticas ao modelo hegemônico estavam relacionadas à dimensão concreta da relação homem/mulher como: a importância da virgindade feminina como requisito ao casamento; a segregação de papéis conjugais; o código moral assimétrico, que legitimava a superioridade masculina; a religião vivenciada como arcaica e repressiva; e a necessidade de ter filhos imediatamente após o casamento. Mas foram mantidos alguns valores do ideal antigo de casamento como a monogamia e a "eternidade" do vínculo conjugal.

Assim, na década de 80, observa-se uma crise decorrente do conflito entre os moldes tradicionais e os moldes vanguardistas, não só relativa ao relacionamento conjugal, mas também com relação à educação dos filhos. A essa crise Nicolaci-daCosta (1995) dá o nome de "desmapeamento", se referindo à convivência, no sujeito, em níveis diferentes, de dois ou mais conjuntos de valores (ou mapas) internalizados em algum momento de sua formação.

Os mapas internalizados durante o processo de socialização primária são rejeitados pelo sujeito quando este adquire mapas mais recentes através de socializações secundárias, mas os primeiros não são erradicados ou integrados, mas deslocados para um nível mais inconsciente (NICOLACI-DA-COSTA, 1985, p. 162). 
Assim, o desmapeamento fica latente no sujeito até que ele precise reproduzir a ordem social, como por exemplo, ao casar-se ou educar filhos. Nesse momento o conflito emerge, dando origem a uma crise: os moldes tradicionais não cabem mais totalmente por estarem ausentes na sociedade, e os moldes vanguardistas também trazem dificuldades para o sujeito por não estarem de acordo com sua socialização primária.

Essa questão é apontada por Figueira (1987, p.29) da seguinte forma:

[...] a sucessão de ideais no processo de modernização, ao ser extremamente rápida, não dá ao sujeito a oportunidade de se modernizar realmente no seu funcionamento, profundamente, nos seus conteúdos e na sua identidade. Preso no descompasso entre a grande velocidade da modernização e a grande inércia da subjetividade, o único modo do sujeito conseguir ser moderno, tentar acompanhar as transformações, é através da modernização do conteúdo do comportamento, através da modernização reativa.

Assim, pode-se concluir que famílias hierárquicas ou igualitárias são polaridades do modo de ser familiar, que não existem ou funcionam unicamente como tal. Seus vários elementos co-existem na realidade familiar brasileira.

3- Razões históricas e ideológicas para a aproximação entre a escola pública e as famílias populares no Brasil

Cunha (1998) realizou um estudo sobre os periódicos da área educacional, publicados de 1930 a 1960, e sobre o Simpósio sobre os Problemas Educacionais Brasileiros, ocorrido em 1959. Vale notar que os periódicos analisados faziam parte das agências de normalização do discurso a ser adotado pelos educadores, ou seja, havia uma tendência de enquadrar o pensamento dentro de parâmetros aceitáveis, levando em conta as opções políticas de quem dirige as revistas educacionais.

Nessa época, o arcabouço da ciência técnica passou a ser fundamental para civilizar o país, e a educação passou a ser fundamental para que se conseguisse modernizá-lo. Passou-se, assim, a buscar em outras instituições, como por exemplo na família, ajuda para a realização das tarefas da escola. Com o intuito de "regenerar a massa popular" e a "transformar o povo", delimitou-se que escola seria a saída. Instaurou-se, então, um projeto político autoritário com relação à educação, cujo 
objetivo era moldar "o povo" em consonância com os anseios do grupo dominante. Falava-se, nessa época, em educação integral, e o objetivo era formar os indivíduos, atuando em seus corpos, para discipliná-los, edificando assim o cidadão civicamente orientado.

Ao mesmo tempo em que a família era vista como complementar na educação, ela passou a ser vista, também, como incapaz de dar conta de suas tarefas tradicionais. Além disso, os novos ritmos de trabalho promoveram a atrofia da família como espaço educativo. Dessa forma, o Estado despontou como imprescindível para educar o indivíduo na direção das finalidades definidas pelas necessidades do país. "A formação individual deveria ser dirigida pelo intuito de beneficiar a esfera pública e não por aspirações inscritas nos desígnios particulares das famílias” (CUNHA, 1998, p.54).

O discurso histórico-sociológico foi utilizado pelos autores que tratavam das relações entre a escola e família, com o objetivo de mostrar a perda do poder decisório da instituição familiar no campo educacional. Ao mesmo tempo, os avanços científicos contribuíram para tornar a família desqualificada para educar, uma vez que houve uma crescente complexidade dentro dos assuntos educacionais. Assim, a família não se mostrava mais capaz de ensinar a base de valores de sustentação do indivíduo na sociedade.

A função da escola, nesse momento, passou a ser a construção da cidadania. Alguns autores, nessa época, diziam que a escola até poderia ser útil no cotidiano das famílias atingidas pelas mudanças sociais modernizadoras. Para uma família considerada normal, bastava a escola, mas para outras, que precisariam ser normalizadas, havia que se pensar em atitudes mais rigorosas em educação. Surgiu aí o tema das famílias desviantes, e a escola passou a ser uma instituição de caráter correcional.

Dessa forma, o Estado, na obrigação de zelar pela ordem pública, assumiu um papel fiscalizador e mantenedor da ordem, policiando a infância das crianças pobres. Padrões indesejáveis de comportamento deveriam ser abolidos por ações coletivas, no âmbito social. Mas as crianças passavam muito mais tempo na família do que na escola, e estava ficando difícil incutir as boas medidas. "A solução para essa dificuldade consistia em envolver as famílias, especialmente as famílias nocivas, por certo, em trabalhos de cooperação entre o lar e a escola" (CUNHA, 1998, p.92).

Assim, o autor aponta que o discurso veiculado por esses periódicos, sobre a relação entre escola e família, tratava essencialmente de uma estratégia normalizadora 
da ordem social, que abrangia as famílias atingidas pela pobreza material e a própria instituição de ensino. O sentido dessa normalização foi minimizar a distância entre as condições concretas da sociedade e aquilo que era tido como ideal. Pode-se dizer que, na realidade, o que se visava era minimizar os efeitos do profundo fosso aberto entre as classes sociais (CUNHA, 1998).

Então, nas primeiras décadas do século 20, iniciou-se um movimento que visava suprimir esse fosso através das oportunidades de acesso à escola para as camadas mais pobres da sociedade. Ao mesmo tempo, foram feitas tentativas assistencialistas para amenizar a distância que separava a família idealizada e as famílias existentes. Houve assim uma tendência a impor um molde às famílias em geral.

Observou-se, no entanto, que essa atitude não solucionou o problema. A problemática passou a ser abordada, então, através de referenciais teóricos socializadores, que privilegiaram a investigação fundada em saberes e práticas oriundos das ciências sociais.

Assim, sob a ótica da sociologia e da antropologia, as relações entre escola e família passaram a ser revistas. Dessa vez, evidenciando-se os desarranjos da ordem social e as deficiências da instituição de ensino. Ao mesmo tempo em que se verificava a urgência da transformação da escola, era imperativo também complementar a transição do país, superando o subdesenvolvimento que predominava no setor rural. Visava-se, sobretudo, a modernização e a superação do hiato entre as classes sociais.

Surgiram, então, dois movimentos: o planificador, que se ocupava de reordenar os serviços educacionais com vistas à democratização das oportunidades de acesso à escola, e o movimento de educação compensatória, que pretendia remediar o equilíbrio entre as diversas estruturas familiares, para o bom desempenho dos serviços escolares.

Cunha (1998) aponta, então, uma continuidade no tocante ao uso das estratégias de normalização, uma vez que o pensamento renovador expressa o retrato atualizado das antigas medidas discriminatórias.

Por outro lado, ele mostra que ocorreu uma ruptura, já que a escola brasileira passou a servir não apenas à elite econômica do país, passando a visar grandes parcelas da população, que eram renegadas ao analfabetismo. Fica claro, então, que o esforço empreendido para democratizar o acesso à educação formal constitui processos contraditórios. Ao mesmo tempo em que se ampliavam vagas nas escolas e as instalavam em locais afastados, acontecia, também através da escola, a massificação necessária para o modelo de exploração. 
Outro aspecto importante, relatado no estudo de Cunha (1998), é que a educação formal propicia uma compreensão objetiva dos conteúdos e, ao invés de um pensamento crítico, leva à contenção do pensamento irracional, visando, em ultima instância, a manutenção do sistema social.

Essas contradições estão presentes também com relação à normalização da família e da escola, uma vez que a educação formal inculca valores morais, padrões de comportamento e de vida, ao mesmo tempo em que dá acesso a benefícios (por exemplo, os serviços de higiene que contribuem sobremaneira para a manutenção da vida).

Cunha (1998) acrescenta que no discurso renovador a problemática psicológica do indivíduo e da família foi compreendida enquanto realidade social e cultural. A contribuição da psicologia foi assimilada à educação no entendimento do processo socializador. Assim, ao apreender o substrato mais íntimo da vida psíquica das pessoas, o que se buscava era a inserção do indivíduo e da família no contexto histórico-social. A educação escolar, ao apropriar-se dos saberes da psicologia científica, buscava um aparelho mais eficiente para integrar o rol das exigências socializadoras, objetivando transformar o indivíduo em ser social.

Esse autor aponta, ainda, que a ambição da escola tornou-se explicitamente civilizadora quando assumiu que suas ações normalizadoras deveriam abranger, acima de tudo, a vida emocional e afetiva da criança. Com um instrumento cientificamente validado, os educadores passaram a fundamentar a visão que tinham da sua clientela, buscando sua homogeneização, o que só é possível através de um ato violento.

Cunha (1998) coloca, por fim, que o movimento nacional renovador foi conduzido em duas direções: de um lado, o caminho da racionalidade estrita, em que o indivíduo é uma parte da engrenagem social, e o sistema escolar é definido pelo sistema social em mudança (a escola deve ser normatizada, sem que se considere a personalidade do educando); do outro lado, valorizando os fenômenos da esfera individual, a tese das diferenças culturais, que determinavam o espaço psicológico, resultando em estratégias normalizadoras que desconsideravam os condicionantes maiores da individualidade e da própria instituição de ensino.

Concluindo, o encontro entre as famílias populares e a escola pública ocorre dentro do seguinte cenário: em função do pretenso déficit cultural que essas famílias possuiriam, a escola passou, então, a se incumbir de educá-las (educação compensatória). Assim, a escola passou a ter o poder, legitimado pela ciência, de julgar 
as práticas familiares, diferenciando aquelas politicamente corretas, daquelas que precisariam ser transformadas. Com isso, fica clara a perda do poder decisório da família no âmbito educacional, aliada ao crescente desenvolvimento da escola, em sua função normalizadora da ordem social. Estabelece-se, assim, a soberania do saber dito escolar, em detrimento do saber originário das culturas familiares. A escola toma as rédeas da função de transformar o indivíduo em ser social, sendo a porta-voz de uma educação formal civilizadora.

\section{III - Brasil: cenário da escola pública}

\section{1 - História da educação formal no Brasil}

A educação no Brasil se iniciou com os primeiros jesuítas, na missão de catequizar e instruir índios, respondendo aos interesses políticos da metrópole e, também, aos objetivos religiosos e políticos da Companhia de Jesus. Um dos motivos dessa catequização era tornar os índios mais submissos para que pudessem aceitar o trabalho exigido pelos colonizadores. Por mais de dois séculos, os jesuítas monopolizaram a educação no Brasil. A instrução propriamente dita acontecia somente para os filhos dos colonizadores e para formação de novos sacerdotes. A influência da ação educacional dos jesuítas no Brasil ultrapassou os limites dos períodos em que aqui estiveram, marcando "profundamente nossa cultura, não apenas em ternos de propagação do catolicismo, mas também pela orientação religiosa que imprimiram ao ensino" (WEREBE, 1997, p.24).

Quando os jesuítas foram expulsos, suprimiu-se o sistema educacional que eles haviam implantado, surgindo o ensino público financiado pelo Estado, baseado nas idéias dos enciclopedistas franceses. Apesar da intenção de modernizar o ensino, declarada por Pombal, esse fato não se concretizou, por falta de meios materiais e humanos. Com a vinda da família real para o Brasil, rapidamente foram criadas instituições de ensino para atender às necessidades da nova situação da colônia. De qualquer maneira, não havia uma ruptura total com o modo de educação jesuítica, e o ensino primário permaneceu abandonado. No período Imperial, a estrutura social e econômica da sociedade brasileira mantinha-se numa base de economia agrícola, patriarcal e escravocrata. Não houve uma política educacional que visasse promover a educação popular. No final do Império, apenas $2 \%$ da população freqüentavam a escola. 
Com a proclamação da República, as estruturas de poder não se modificaram de maneira significativa. Fica clara a distinção de um Brasil que se desenvolve social e economicamente e beneficia apenas as camadas mais favorecidas, enquanto que a maioria da população continua sobrevivendo em condições precárias. O magistério também continuava sendo encarado como um sacerdócio (WEREBE, 1997).

Souza (2000), ao tratar das reformas educacionais do final do século XIX, utiliza como principal fonte o parecer de Rui Barbosa acerca da reforma do ensino primário, publicado em 1883. A partir da segunda metade do século XIX, houve no mundo o fenômeno da escolarização em massa, que instituía o ensino público como responsabilidade estatal e a secularização do ensino e da moral, além da nação e da pátria como princípios norteadores da cultura escolar. A educação popular era concebida como um projeto de integração ideológica e política. Dessa forma, os currículos tinham forte vínculo com a formação da nação.

No Brasil, também no final do século XIX, a escola popular foi elevada à condição de redentora da nação e de instrumento de modernização. Rui Barbosa reiterava a importância da renovação pedagógica e a inspiração no modelo dos países avançados. A nova escola deveria estar pautada na educação do corpo, na ciência, nos valores morais e cívicos e nos saberes instrumentais para o trabalho.

Já os anos 20 e 30 foram marcados por uma grande agitação e pelo confronto de idéias. A partir daí, uma verdadeira guerra ideológica se instalou entre progressistas e conservadores no campo da educação. Em 1924 foi criada a Associação Brasileira de Educação, reunindo educadores que analisavam e debatiam os principais problemas do ensino no país. A partir da revolução de 30, os debates em torno de idéias sociais, literárias, políticas, científicas e educacionais se intensificaram. Nessa época, houve uma discussão, entre católicos e leigos, quanto às orientações gerais da política educativa no país. Os primeiros defendiam uma concepção religiosa e humanista do ensino, reclamando um financiamento público para a educação particular. Já os segundos, impulsionados pelos movimentos progressistas, defendiam que apenas a escola pública estaria a garantir as mesmas chances educativas para todos os cidadãos brasileiros (AKKARI, 2001).

Em 1932, foi lançado o famoso Manifesto dos Pioneiros da Educação Nova, que defendia a escola pública gratuita, obrigatória, assim como a laicidade do ensino e o convívio entre os gêneros nas escolas. A idéia de democratização do ensino já estava presente nessa concepção de educação nova, e a escola foi finalmente definida como 
uma instituição social. De qualquer maneira, a escola nova questionou a escola tradicional, mas não renovou o ensino nem no Brasil, nem nos países onde essa escola teve origem. Esse movimento exaltou o poder da educação, como se ela pudesse por si só reformar a sociedade (WEREBE, 1997; AKKARI, 2001).

Na época do Estado Novo, a ditadura de Vargas, de 1937 a 1945, houve a implantação de uma política populista e paternalista em relação às massas trabalhadoras. Nessa época, instituiu-se a obrigatoriedade do ensino e de trabalhos manuais em todas as escolas primárias, uma vez que o desenvolvimento econômico exigia um número cada vez maior de trabalhadores qualificados. Registrou-se nessa época uma expansão do ensino primário, mas a maioria das crianças em idade escolar, ou não ingressava na escola, ou nela permaneciam por pouco tempo.

No final da Segunda Guerra Mundial, houve uma aliança do Brasil com os Estados Unidos, marcando uma crescente influência americana no domínio econômico e cultural brasileiro. Nos anos 40 e 50, registrou-se uma acelerada industrialização e uma progressiva urbanização no país. Em 1948 foi encaminhado à Assembléia, o projeto de Lei de Diretrizes e Bases da Educação Nacional, baseado em propostas educacionais democráticas de outros países. O projeto no Brasil só foi aprovado em nova versão, em 1961, mas os progressos no ensino não foram extraordinários (WEREBE, 1997; AKKARI, 2001). A seletividade se manteve, apenas 14,8\% dos alunos matriculados na $1^{\mathrm{a}}$ série, em 1945, chegaram à $4^{\mathrm{a}}$ série. Em 1955, essa porcentagem elevou-se a 16,5\%. A falta de vagas nas escolas era um problema comum nas cidades brasileiras. No setor público ocorreram medidas improvisadas, desdobrando-se o período escolar, que se reduziu a até duas horas diárias. "O ensino oferecido, que já não era o modelo de eficiência, baixou ainda mais o nível, sendo realizado por professores muitas vezes mal preparados, trabalhando em condições precárias" (WEREBE, 1997, p. 64).

O projeto de lei de Diretrizes e Bases da Educação Nacional voltou a ser considerado em debates a partir da apresentação do substitutivo da autoria do deputado Carlos Lacerda. Esse substitutivo representava um retrocesso em matéria de educação, ameaçando seriamente a escola pública, ao propor um verdadeiro monopólio do ensino privado. Em 1961, essa lei foi aprovada, e a campanha em defesa da escola pública só conseguiu reduzir os estragos. Partidários do Ensino Privado tiveram compensações, a lei garantiu igualdade de tratamento por parte do poder público para estabelecimentos oficiais e particulares, e as verbas públicas podiam ser carregadas para a rede particular. 
Houve uma ampliação da rede pública, mas não suficiente para suprimir as necessidades existentes. O ensino primário cresceu em termos de matrícula e de pessoal docente.

A partir dos anos 50 a tendência desenvolvimentista começou a ganhar terreno e a educação se voltou para a necessidade de mão-de-obra para as indústrias. Num período muito breve, de 1962 a 1964, houve um ambiente de entusiasmo e liberdade, onde se desenvolveram idéias em prol da educação popular, quando se destacaram os grupos ligados a Paulo Freire. Mas a partir de 1964, com a instauração da Ditadura Militar, houve grande prejuízo à ciência e à cultura brasileira devido ao êxodo de cientistas e intelectuais, por perseguições políticas. Esse regime tentou implementar uma política educativa centrada nos conceitos de racionalidade, eficiência e produtividade. Houve repressão no campo da educação, e foi instaurado o terrorismo nas redes de ensino. Houve, no entanto, progressos do ponto de vista quantitativo, com a expansão da rede escolar. Ainda assim não se conseguiu atender todas as crianças em idade escolar, e a exclusão da maioria que ingressava no ensino primário se manteve.

O governo militar extinguiu os movimentos de educação popular, e a educação passou a ser vista em termos de custos e benefícios. Houve uma subordinação do ensino às necessidades do mercado de trabalho, e a profissionalização do ensino médio passou a ser umas das propostas ao plano da educação.

Outro aspecto importante do regime militar foi que ele se revelou abertamente favorável ao ensino privado. Nos primeiros anos desse regime, o ensino privado prosperou de maneira extraordinária. Em 1983, um decreto contou com um dispositivo favorecendo escandalosamente o ensino privado, com prejuízo à escola pública. A partir daí, a expansão do ensino público dependeria da autorização da escola privada.

Assim, o ensino público se deteriorou, abandonado pelos poderes governamentais, mantendo-se carente de recursos e funcionando em condições precárias, com professores maus remunerados, o que favorecia a transferência de alunos para as escolas particulares. Além disso, nessa época, multiplicaram-se os ataques à escola pública, como se suas deficiências lhe fossem inerentes.

O período que precedeu a promulgação da nova Constituição se caracterizou por debates entre partidários da escola pública e da escola privada. A questão se voltava para o destino das verbas públicas para a educação. Os partidários da escola pública reivindicavam a atribuição exclusiva dos recursos públicos a essa escola. No final das contas, no texto definitivo da constituição de 1988, a concessão de recursos públicos para entidades privadas de ensino sem fins lucrativos foi garantida. 
Em 1990, foi preparado e apresentado à Câmara um projeto, constituindo uma obra de ampla consulta aos setores interessados na educação, que resultou da participação democrática de pessoas que realmente viviam os problemas do ensino. No entanto, antes que o trabalho da Câmara fosse concluído, o senador Darci Ribeiro apresentou um substitutivo ao projeto, que foi aprovado em 1993. Esse texto, a Nova Lei de Diretrizes e Bases, não representa a expressão de todas as aspirações enunciadas no projeto da Câmara.

Akkari (2001) demonstra que a partir dos anos 90 houve uma exaltação dos temas ligados à Educação. No entanto, aconteceu também um maior descompromisso do Estado no setor. Cresceram, de maneira importante, as responsabilidades da iniciativa privada e das organizações não governamentais quanto à educação. As noções de qualidade total acabaram substituindo o conceito de desigualdade social. Assim, a reprodução das desigualdades sociais encontrou-se amplamente facilitada e legitimada, uma vez que as falhas foram atribuídas às inaptidões individuais, enquanto os determinantes sociais e culturais continuavam negligenciados.

Esse autor aponta, ainda, um outro agravante: desde 1985, o capital escolar desempenha um papel cada vez mais importante. Com a privatização e a descentralização da educação, o ensino particular se desenvolveu, tornando-se a ferramenta preponderante para a garantia do domínio do capital escolar. Antigamente, quando se buscava uma escola particular, essa ação significava direito de família ou pluralidade ideológica e religiosa. Hoje, essa busca está mais ligada a uma racionalidade do tipo administrativo e econômico, porque cursar uma escola particular é a única possibilidade de se conseguir mobilidade social.

Outro aspecto importante é que a descentralização do ensino fundamental não foi acompanhada por um dispositivo de apoio financeiro, técnico e pedagógico suficiente e nem por uma garantia acerca da qualidade do ensino ministrado nas escolas municipais. Esse fato reforça a desigualdade entre estados, comunidades e regiões, porque muitas vezes as rendas são inversamente proporcionais às necessidades da população (AKKARI, 2001).

Atualmente, ao se tratar da educação no Brasil, é fundamental situá-la no contexto internacional. O Brasil tem recebido ajuda financeira de instituições como o Banco Mundial, para subsidiar suas ações relativas à educação. No entanto, muitos desses financiamentos estão mais orientados para realizações materiais visíveis do que para reformas estruturais. Segundo Romanelli (1987, p.203): 
[...] na medida em que as agências internacionais de ajuda à educação nos países de terceiro mundo partem de uma concepção de subdesenvolvimento, que na realidade procura explicar o global pelo particular, elas têm também por estratégia a compartimentação da realidade.[...] Nesse sentido, não só favorecem a importação de técnicas de ensino modernizantes, que privilegiam o estudo da aprendizagem em si, isolando-a do seu contexto, mas também, o que é ainda mais grave, imprime uma direção quase única à pesquisa educacional. Esta passa então a refletir a compartimentação e a desvalorizar os estudos do macrossistema educacional e suas relações com o contexto global da sociedade.

Observa-se que a estratégia de ajuda internacional ataca primeiramente o problema em seus aspectos quantitativos. As propostas de democratização da educação acabam visando a adequação da educação às necessidades de desenvolvimento, priorizando o treinamento de pessoal, a reorganização do currículo, o aumento dos recursos materiais, entre outros. As mudanças quantitativas favorecem uma expansão da oferta do ensino, mas não favorecem uma real mobilidade social (ROMANELLI, 1987).

De Rossi (2001) também enfoca essa questão, afirmando que o Banco Mundial tem incentivado políticas de gestão nas escolas, em que os consumidores (pais e alunos) elegem os provedores (escolas e instituições), tomando assim um papel mais ativo e exigente.

Segundo a Nova Lei de Diretrizes e Bases da Educação Nacional, LDB, aprovada em 1993, alguns princípios devem ser observados para que se consiga a gestão democrática do ensino público: a participação dos profisssionais da educação na elaboração do projeto pedagógico da escola e a participação das comunidades escolar e local em conselhos escolares ou equivalentes. O Estado, assim, se configura como um instrumento de solidariedade organizada, pedindo aos cidadãos que assumam voluntariamente as organizações de auto-ajuda.

Ao analisar a literatura educacional e a convocação televisiva para participação da comunidade na escola (como, por exemplo, “amigos da escola"), De Rossi (2001) aponta a tendência de se encarar a gestão coletiva, como se o interesse coletivo fosse natural e comum, constituído com valores neutros e consensuais. O que acaba ocorrendo é que a prática desse tipo de gestão se torna contraditória, ela é mais desafiadora, mas também mais legitimadora dos grupos de interesses; e também as duas coisas ao mesmo tempo. Quando ocorre verdadeiramente a participação, acontece 
[...] um exercício democrático de participação decisória que é lento, processual e conflituoso, por lidar simultaneamente com o conflito de interesses (de classes, partidos, grupos) e de valores culturais tais como crenças, regras (in)visíveis de regulação, pontos de vista diferentes, (res)sentimentos (raivas, hostilidades, solidariedade) (DE ROSSI, 2001, p. 94).

$\mathrm{Na}$ ideologia liberal, as estratégias participativas permanecem ocultando o conflito e confirmando os efeitos reguladores e desmobilizadores da democracia. Essa nova ordem não está, necessariamente, de acordo com as vias de emancipação e legitimação da escola pública, de acordo com os princípios de Paulo Freire. Apesar de uma leitura superficial apontar similaridades entre a atual bandeira de democratização e a reivindicação histórica de setores progressistas, isso na realidade não se dá. Porque uma descentralização implica necessariamente em alterações efetivas no funcionamento das várias esferas do poder público, e a nova LDB não foge da inspiração neoliberal.

Assim, as reformas educativas dos anos 90, ao preconizarem a entrada das famílias na escola, visam primordialmente seu auto-financiamento. Atualmente, as mudanças aceleradas promovem uma desintegração dos laços sociais, o que limita, em longo prazo, a confiança informal, o compromisso mútuo e a solidariedade. A meta é unir a educação aos requisitos de uma nova ordem de trabalho, que vão do aprendizado ao mercado. Além disso, observa-se uma mudança no aspecto legitimador da estrutura burocrática: antes implicava na aparência e em gestos ríspidos do diretor severo, do professor exigente, do supervisor rígido. Hoje tem-se uma outra imagem: os professores com salários baixos são apreciados como criaturas flexíveis, mantendo sua capacidade de mudar e adaptar-se ao fluxo das circunstâncias, são bons ouvintes, cooperativos e capazes de desprendimento do passado.

Tudo sem queixas, sem traições, sem mau humor. Alimentam-se da ficção de que já não competem entre si, de que não existe mais antagonismo, confiam na fragmentação dos grupos e, acima de tudo, que o gestor administra o poder horizontalmente - em grupo - como um líder que está ao seu lado (DE ROSSI, 2001, p. 98).

Concluindo, diferentemente da lógica da autogestão enquanto utopia dos educadores progressistas, as demandas participativas do Banco Mundial e da nova LDB estão mais atreladas às concepções tecnocratas. Assim, a autonomia definida como autogestão e a descentralização são utilizadas para vencer a crise da centralização burocrática. 
Trata-se da prática de co-gestão com controle remoto, com autonomia administrativa/pedagógica outorgadas e controladas, com descentralização de decisões circunscritas ao nível técnico operacional. Trata-se de uma alternativa moderna de despolitizar o sistema, inserindo a participação de professores, pais, alunos e comunidades locais no processo que se diz neutro. No entanto, é uma prática decorrente da nova estrutura de poder comandada pelos maiores grupos econômicos, operando em bases supranacionais para reinventar instituições, privatizá-las e ampliar o consumo em escala mundial (DE ROSSI, 2001, p. 98).

Vale ressaltar que apesar do efeito regulador e moderador dessa nova forma de poder, ainda existe espaço para a construção democrática participativa. Segundo De Rossi (2001), os espaços se tornam espaços de (re)interpretação de experiências, com a produção e a crítica do conhecimento. O trabalho preconizado em equipes acaba possibilitando também a tomada de consciência, o que pode consolidar uma participação decisória. Se os conflitos interiores à instituição escolar, ao invés de serem camuflados, através da busca de um consenso, forem trabalhados e avaliados, dar-se-á espaço à sociabilidade e solidariedade, o que (re)constrói laços sociais e potencializa o alívio das tensões nos grupos. Por fim, partindo de uma visão dialética, a autora coloca que, apesar do fundamentalismo conservador presente nas políticas de educação atualmente, observa-se pontos de fragilidade no sistema, havendo regras políticas e morais conflitantes.

Na realidade social fugidia das escolas públicas, pulsa um aprendizado perceptível, audível (nem sempre registrado), de (re)interpretação e de (re)criação de propostas curriculares, de projetos pedagógicos, de planejamento e orçamentos participativos articulados em processo, pelas práticas de gestão descentralizadoras e democráticas (DE ROSSI, 2001, p. 102).

Dessa forma, é de suma importância conhecer a macroestrutura que determina em grande parte a realidade escolar; por outro lado, no contato cotidiano com as escolas, é fundamental que se dê ouvido a essa resistência sutil, a esse mecanismo de subversão da ordem proposta, que caminha rumo à participação democrática efetiva. 


\section{2 - Avaliação do ensino público}

Algumas das novas estratégias implementadas pelo Estado, no sentido de buscar uma suposta melhoria na qualidade do ensino, já foram avaliadas em estudos realizados em escolas públicas. Um deles ressalta o equívoco que pode estar ocorrendo, quando se generalizam índices estatísticos, tomando-os como prova de aumento de qualidade.

Carvalho (2001), ao realizar um estudo numa escola pública municipal, com alunos de quarta série, observou que índices baixos de repetência eram "inventados" pela escola, uma vez que eles seriam utilizados em sua avaliação enquanto instituição de ensino. Dos 85 alunos que estavam com um desempenho insatisfatório no decorrer do ano, somente 11 foram retidos (o número exato exigido pela Secretaria Municipal de Educação). Não havia, também, um critério explícito de avaliação usado por todas as professoras e, no inicio do ano, ainda não conhecendo bem os alunos, elas eram orientadas a colocar não satisfatório para todas as crianças. Aquelas que se desenvolvessem ganhariam o conceito satisfatório no decorrer do ano. Assim, ocorria sempre uma diminuição do critério não satisfatório. A autora explica que "o caminho inverso não seria permitido, do S (satisfatório) para o NS (não satisfatório), pois teriam dificuldade em explicar essa piora aos órgãos centrais da Secretaria Municipal de Educação" (CARVALHO, 2001, p. 242).

Assim, apesar de os discursos oficiais apontarem uma melhoria de fluxo, racionalização e eficiência, e mesmo uma elevação da qualidade do ensino, o que ocorre na realidade é que a escola exclui alguns alunos da lista de retidos para manter o índice de repetência o mais baixo possível. Nota-se que esse tipo de avaliação diz muito pouco sobre os processos de ensino-aprendizagem ocorridos no interior da escola, e a queda no número de repetentes não representa avanços na qualidade da aprendizagem.

Dessa forma, enquanto a produção das estatísticas estiver atrelada às fontes de avaliação das escolas e de seus profissionais, as pressões por "qualidade" acabarão se refletindo na produção dos índices. O máximo que se pode afirmar, a partir deles, é que um menor número de crianças está sendo reprovada, o que representa economia para o sistema. "O principal efeito das medidas de progressão automática era que a escola envolvia-se, antes de qualquer coisa, com a produção de um índice alto de sucesso e não com a produção do sucesso escolar propriamente" (CARVALHO, 2001, p. 15). 
Concluindo, a autora coloca que mais importante do que mudar a cultura da repetência é oferecer para as escolas turmas menores, espaços adequados, materiais pedagógicos e até um trabalho de recuperação escolar, além de condições de uma constante formação dos profissionais de ensino.

\section{3 - As mudanças no papel do professor}

A profissão de professor, especialmente do ensino primário, foi tida como sacerdócio por muito tempo, tendo sido "relegada" às mulheres (socialmente inferiores na hierarquia da sociedade patriarcal). Enquanto não havia uma regulamentação da profissão, ela seguia as normas mais amplas da comunidade, e o professor se encaixava ao que era dele esperado. Num dado momento histórico, ele se assemelhou a um comerciante, em outro, ele pregava aos seus discípulos, de modo semelhante a um padre.

A partir da metade do século XVI, os professores passaram a ter responsabilidade pela formação do aluno, sendo encarregados do seu desenvolvimento moral, utilizando, para isso, regras disciplinadoras vigorosas, como castigos físicos e punições.

Segundo Ariès (1978), foi entre os moralistas e educadores do século XVII que se formou o sentimento da infância que inspirou toda educação até o século XX. Não sendo mais vista como distração e brincadeira, a infância passou a ser vista com interesse psicológico e preocupação moral. Era preciso que se conhecesse melhor a criança para corrigi-la e curá-la de suas imperfeições. As crianças deveriam ser preservadas e disciplinadas, havendo uma grande preocupação com sua saúde e higiene. A partir daí, o professor deveria corrigir e moralizar os alunos de maneira sistemática.

No final do século XIX, no Brasil, o parecer de Rui Barbosa sobre as renovações educacionais incluía uma nova prescrição à função docente: ele atestava que o novo método educacional, baseado na observação, requeria do mestre mais presença de espírito, mais benevolência de ânimo, mais recursos intelectuais, em suma, o esmerado cultivo da vocação pedagógica (SOUZA, 2000).

Com o avanço tecnológico e científico, a partir da década de 50, exigiu-se do professor uma postura racionalista e técnica, uma vez que seu conhecimento deveria estar embasado e validado por novas descobertas científicas. 
Atualmente, a ênfase na formação de professores parte de uma abordagem tecnocrática. Separa-se a concepção da execução, e o conhecimento é padronizado para que se possa administrá-lo e controlá-lo. Os cursos de formação de professores dão prioridade ao como fazer, mais do que ao porque fazer (SIGOLO; LOLLATO, 2001).

Carvalho e Vianna (1994) indicam que a tendência a tornar impessoal o trabalho público pode estar contribuindo de maneira negativa com a realidade escolar, uma vez que pode significar a exclusão ou a diminuição da afetividade, do vinculo pessoal e da informalidade nas relações das educadoras com os alunos e com as famílias. E isso poderia colocar em risco a qualidade do ensino.

Essas autoras observaram ainda que as educadoras lidam com problemas sócioafetivos de seus alunos, muitas vezes sem condições de poder contribuir. É comum sentirem-se impotentes e perplexas, uma vez que dificilmente dispõem de um instrumental teórico que lhes permita uma compreensão crítica da família. Pelo contrário, elas estão imersas na ideologia e no modelo de amor materno dominante. Segundo Rosenberg (apud CARVALHO e VIANNA, 1994, p.176),

[...] essa ideologia do amor materno, assim como o paradigma funcionalista da família nuclear, completa com a divisão sexual do trabalho, perpassam o todo social: orientam as políticas sociais e escolares; produzem conhecimento científico; são divulgadas pela mídia, por profissionais da psicologia e ensinadas às professoras na sua própria formação.

\section{IV - Estudos recentes sobre o papel da família na escolarização dos filhos}

\section{1- A participação dos pais na escola}

Oliveira (1999), ao estudar a participação das famílias no contexto escolar a partir de um enfoque crítico-reflexivo, buscou diferenciar o que se espera como participação, identificando duas abordagens. A primeira, proposta dentro de parâmetros rígidos, acontece de forma que as pessoas são envolvidas apenas para legitimar as relações sociais já existentes. Isso acontece por exemplo, nas reuniões de pais e mestres, ou reuniões para entrega de boletins, nas quais os assuntos versam sobre comportamento e mau rendimento escolar, havendo, por um lado, a cobrança dos professores e, por outro, o afastamento dos familiares. Nesse caso, o diálogo é 
dificultado, havendo um grande número de participantes, o que impede a manifestação de muitos deles dentro do tempo previsto.

Segundo a autora, ao contrário dessa proposta, a participação pode ser defendida como possibilidade de inserção dos sujeitos nos espaços decisórios de poder, acontecendo como possibilidade de transformação social. Nesse sentido, a escola deveria implantar ações nas quais as pessoas pudessem socializar idéias, contribuir com sugestões e projetos.

No entanto, Samartini (1995) afirma que a participação dos pais na gestão da escola pública é muito insatisfatória. $\mathrm{O}$ foco da participação ainda se baseia na ajuda que os pais oferecem à escola, doando recursos ou trabalhando nos projetos de modo passivo, não tendo voz ativa na condução e na decisão de assuntos importantes.

Para essa autora, o importante seria que os pais pudessem decidir a respeito do que ocorre na escola. Ela sustenta ainda que é uma tônica o fato de a escola estar sempre apontando o desinteresse dos pais e de, ao mesmo tempo, os pais acusarem a escola de dificultar e impedir sua participação nas discussões, nas decisões e também no conhecimento das propostas da escola.

Confirmando esse fato, Perez (2000) verifica, ao estudar as representações de alunos, pais e professores de uma escola pública, que o discurso da escola traz sempre a premência da participação dos pais, mas são poucas as reuniões marcadas pela escola para estar com eles. Além disso, quando essas reuniões aconteciam, os pais tinham pouco espaço para expor opiniões, mostrando uma postura passiva frente à fala da professora. Assim, ela conclui que os pais eram chamados à escola para participar de eventos e festas com fins de arrecadação de fundos para a melhoria da escola, não tendo essa participação influência no projeto pedagógico da escola.

Alguns autores (CARVALHO e VIANNA, 1994; ZAGO,1998) defendem que a participação da família na escola tem um papel importante no curso da escolarização dos filhos, mas ela não garante, necessariamente, o sucesso escolar. No entanto, essa participação tem sido atualmente cobrada como determinante para um bom andamento escolar. Nenhum outro tipo de condicionante, por exemplo, a escola ou a relação com o professor, costuma ser avaliado, o que acaba gerando equívocos.

Lahire (1997) levanta um outro aspecto ao tratar da participação dos pais na escola. Ele coloca que a omissão parental, tão freqüentemente lembrada para justificar as dificuldades escolares, é um mito produzido pelos professores que, ao ignorar as 
lógicas das configurações familiares, deduzem que os pais não se incomodam com os filhos.

Ele afirma que, na realidade, os discursos sobre a omissão parental acontecem quando os pais estão ausentes do espaço escolar. O fato de não serem vistos é imediatamente interpretado como indiferença em relação aos assuntos da escola. Alguns professores parecem pensar que a ausência da relação e contato com a família explica o fracasso escolar das crianças.

Segundo o autor, também pode acontecer que, através das práticas de fazer vir os pais à escola, de vê-los e de encontrá-los, pode estar ocorrendo uma nova imposição de quadros sociais simbólicos e normas de comportamentos hegemônicos, não somente às crianças, mas também aos adultos dos meios populares. Assim, muitas das ações da escola concernentes à relação da família com a escola, que buscam melhorar o quadro de fracasso escolar, acabam tendo pouca relação com esse objeto. Ações como festas na escola ou a visão da escola como um ambiente onde os pais vêm dar uma mão ainda visam, no fundo, a integração moral e simbólica dos meios populares nas instituições legítimas.

Essas ações dizem respeito aos costumes escolares, às normas legítimas da sociabilidade e a uma determinada forma histórica de vida pública. Mas não tem relação com os fundamentos das diferenças culturais que estão na origem das dificuldades escolares entre uma parte das famílias populares e a escola (LAHIRE, 1997, p. 336).

O autor ainda aponta como resultado de sua pesquisa o fato de alguns pais realmente participarem da vida escolar da maneira que a escola o exige, em reuniões, conselhos, e excursões. Mas isso não pode ser considerado como causa do sucesso da criança. $\mathrm{O}$ autor questiona o fato de que a simples participação dos pais poderia modificar o desempenho da criança.

\section{2- As configurações familiares}

Apesar de considerar importante investigar a contribuição da escola na produção das dificuldades escolares, Lahire (1997) buscou em seu estudo compreender como as configurações familiares auxiliam ou dificultam o processo de escolarização dos filhos. O autor entrevistou 26 famílias, em suas casas, juntou notas etnográficas sobre cada um 
dos contextos das entrevistas, além de informações escolares, como fichas, cadernos de avaliação, entrevistas na escola com as crianças, com os professores e com os diretores.

Ele partiu do pressuposto de que a criança se desenvolve a partir das relações de interdependência com as pessoas que a cercam com mais freqüência, os membros de sua família por exemplo. Ela não reproduz necessariamente as formas de agir de sua família, mas a modalidade de funcionamento familiar é o pano de fundo onde se traçam os comportamentos e representações possíveis para ela. Esse autor afirma que os resultados escolares da criança só podem ser avaliados quando se reconstrói a rede de interdependência familiar, e a maneira como esta reage às formas escolares. Muitas vezes existe um elo impossível entre o universo familiar e o universo escolar e esse é um dos fatores que podem contribuir para a dificuldade escolar das crianças.

Os alunos podem também, de acordo com as diferentes formas de autoridade da família, estar vivendo em esquemas de dupla coerção, por estarem submetidos a regimes disciplinares diferentes ou opostos, em casa e na escola. Assim, o investimento familiar pedagógico pode ser mais ou menos adequado para atingir o objetivo de ajuda na escolarização da criança. Maneiras de incitar a criança a ter sucesso escolar podem ou não atingir esse fim.

O autor afirma que os pais, na verdade, não são indiferentes aos comportamentos e desempenho escolares, o que existe é uma incidência grande do ato de bater nos filhos por causa das questões escolares. Esse fato comprova uma distorção entre o fim visado, que é um bom resultado escolar, e o meio utilizado para atingi-lo. Existe, assim, um superinvestimento escolar, mas que não leva ao efeito esperado.

Um outro aspecto discutido no trabalho é que muitas vezes as famílias, ao se sentirem impossibilitadas de ajudar os filhos do ponto de vista escolar, começam a inculcar-lhes a necessidade de se submeterem à autoridade escolar, impondo-lhes a necessidade de fazer o que é pedido, tornando-as pessoas relativamente dóceis. "Os pais visam, desse modo, uma certa respeitabilidade familiar da qual os seus filhos devem ser os representantes" (LAHIRE, 1997, p.15).

O autor refuta a hipótese de que é através do capital cultural adquirido ou conquistado que se pode explicar o sucesso escolar dos filhos de camadas populares. Muitas vezes o capital cultural não pode ser transmitido de maneira tranqüila porque sua transmissão depende da situação de seus portadores, da relação dos pais com os filhos e até da disponibilidade em transmitir as disposições culturais. Assim, a maneira como a configuração familiar vive e trata a experiência escolar da criança, e que muitas vezes 
através dela revive sua própria experiência escolar, feliz ou infeliz, se mostra como um elemento central na compreensão de certas situações escolares.

Lahire (1997) diz ainda que ao se tratar do tema família não se deve utilizar concepções globalizantes, que a vêem como um pequeno mundo totalmente coerente e uniforme. Essa visão subestima a diferença de investimentos, disposições, orientações e interesses que caracterizam os diversos componentes da configuração familiar.

Essas diferenças, esses desvios ou essas contradições no seio da família (algumas contradições se apresentam, às vezes, até mesmo nos indivíduos) são também relações de forças, tensões entre diferentes pólos familiares, e a escolarização da criança depende, então, do produto dessas relações de forças modificáveis pela evolução dos destinos individuais (nascimento de outra criança, morte de um adulto, partida ou chegada de outros membros da família) (LAHIRE, 1997, p. 208).

O autor ressalta que, em condições materiais e culturais pouco propícias, algumas configurações familiares podem, a partir de um pequeno capital escolar, cuidar da escolaridade da criança de forma a fazê-la chegar num rendimento máximo. Assim, pela diversidade de exemplos de sucesso escolar, provenientes dos meios populares, é importante observar que não há um estilo familiar único que leve à conclusão da escola primária com sucesso. Não existe um único fator que explique por si só o sucesso dos alunos.

Ainda quanto à teoria do capital cultural já comentada, o autor coloca que ela só faz sentido se esse capital cultural for colocado em condições que tornem possível sua transmissão. Ele afirma que nem sempre essa transmissão ocorre na família. Em algumas situações, o patrimônio cultural é chamado pelo autor de "patrimônio cultural morto", porque apesar de rico não é acessível aos filhos. Por outro lado, há famílias em que os pais não lêem, mas conseguem desempenhar um papel importante para desenvolver a cultura escrita de seus filhos. Eles atuam como intermediários, fazendolhes perguntas sobre o que estão lendo, levando-os à biblioteca, entre outros.

Algumas vezes, em famílias com pouco capital escolar, ou até no caso de pais analfabetos, pode existir um lugar simbólico com relação à escolarização da criança, existindo uma escuta atenta ou um questionamento interessado dos pais, mostrando que o que é feito na escola tem sentido e tem valor. Quando a escolarização da criança é valorizada na família, quando ela é solicitada a demonstrar esse conhecimento proveniente da escola, este ganha um reconhecimento, uma legitimidade no seio da 
família. Quando não se tem qualquer outro tipo de ajuda direta, o processo de legitimação familiar tem um papel central na possibilidade de uma boa escolaridade no curso primário.

Em outros casos, os pais comunicam, sem que percebam, seus complexos, suas angústias, suas próprias dificuldades passadas, o que evidencia que o capital escolar nunca está dissociado de uma experiência escolar, seja ela feliz ou infeliz. Assim, do ponto de vista da escolaridade da criança "é sem duvida preferível ter pais sem capital escolar a ter pais que tenham sofrido na escola e que dela conservem angústias, vergonhas, complexos, remorsos, traumas ou bloqueios" (LAHIRE, 1997, p. 345).

\section{3- A mobilização familiar para a escola}

Mobilização escolar familiar, segundo Viana (2000), significa identificar e descrever atitudes e intervenções práticas das famílias voltadas sistemática e intencionalmente para o rendimento escolar dos filhos, o que são comportamentos e condutas características das camadas médias. Essas condutas implicam um acompanhamento minucioso da escolaridade dos filhos: escolha da escola, contato freqüente com os professores, acompanhamento nos deveres de casa, assiduidade às reuniões convocadas pela escola, entre outras.

Ao pesquisar a trajetória escolar e familiar de alunos universitários de graduação e pós-graduação provenientes de camadas baixas, Viana (2000) apontou o caráter de imprevisibilidade contido no processo de escolarização dessas pessoas. O estudo evidenciou uma grande heterogeneidade de configurações familiares e de situações que provocaram a longevidade escolar. Cada caso mostrou uma configuração de traços explicativos que não se repetia de maneira sistemática para cada sujeito estudado. Essa pesquisa mostrou ainda

[...] que é possível acontecer longevidade escolar nas camadas populares, mesmo na ausência de práticas familiares, tais como as descritas acima. Não se identificaram, em nosso estudo, investimentos específicos e intencionais na carreira escolar dos filhos que nos permitissem reconhecê-los como um traço explicativo dessas situações de longevidade escolar (VIANA, 2000, p. 53).

No entanto, as famílias de camadas populares são normalmente cobradas e responsabilizadas pelo fracasso escolar dos filhos. É esperado que elas cumpram uma 
série de prescrições, proveniente dos extratos médios da população, a tal mobilização escolar familiar, com vistas a conseguir que os filhos tenham um bom desempenho escolar.

Lahire (1997) também questiona esse termo porque ele implica na busca explícita e intencional, por parte da família, de desenvolvimento de estratégias educativas em torno do projeto escolar dos filhos, o que não é possível em algumas famílias. No entanto, mesmo sem conseguir essa mobilização, há casos de sucesso escolar.

Ele coloca também que, por outro lado, mesmo quando existe a mobilização familiar, não existe necessariamente o sucesso escolar. Há situações em que o pai fiscaliza as tarefas, corrige, faz os filhos estudarem durante as férias, encontra-se regularmente com os professores, mostra descontentamento quando os resultados escolares estão ruins, e nem por isso a rentabilidade escolar do filho é satisfatória. $\mathrm{O}$ efeito pode até ser contrário, quando a mobilização escolar acontece de forma que os pais punem, sem verdadeiramente conseguirem ajudar. Quando os pais só conseguem incitar o filho para o trabalho escolar a partir de sanções, essa mobilização familiar pode produzir efeitos negativos.

Assim, fica clara a idéia de que mobilização familiar escolar não produz necessariamente o sucesso escolar, mas existem formas específicas de envolvimento das famílias populares na escolarização dos filhos que facilitam essa longevidade. A autora afirma "que as famílias populares participam da construção do sucesso escolar dos filhos de um modo diferenciado, nem sempre facilmente visível e voltado explícita e objetivamente para tal fim" (VIANA, 2000, p. 58).

Complementando a questão da mobilização familiar, Zago (2000) traz uma contribuição importante, uma vez que questiona sua funcionalidade, apontando que ela está atrelada a muitos outros fatores. Apesar de a origem social dos alunos influenciar no seu sucesso ou fracasso escolar, existe uma constelação de outros fatores, compreendidos nas suas relações de interdependência, como a mobilização familiar voltada para as atividades escolares dos filhos, as práticas de socialização e transmissão de valores, o apoio sistemático de um professor, a demanda escolar relacionada a atividade profissional, o tipo de trajetória social e escolar, entre outras situações, que influenciam no fracasso ou sucesso escolar de jovens de camadas populares.

Zago (2000) ressalta que as difíceis condições de sobrevivência, por causa da baixa renda, o trabalho instável, a moradia às vezes na favela ou em condições 
precárias, são elementos que dificultam a freqüência escolar, além de promoverem instabilidade e vulnerabilidade às pessoas. A mobilização familiar é voltada em primeiro plano para a sobrevivência. Além disso, nos meios populares as crianças não têm seus dias organizados em torno de atividades escolares, o que é estratégia comum nos extratos médios da população. Observou-se ainda, em pessoas que foram vítimas do fracasso escolar, que na maioria das vezes elas atribuíam a si mesmas toda a responsabilidade pelo baixo nível escolar, oscilando entre a aproximação e o recuo da instituição de ensino.

Também D’Ávila (1998), visando estudar a contribuição da família no sucesso escolar dos filhos, entrevistou famílias que pertencem a estratos médios-baixos e baixos da sociedade, cujos filhos apresentavam resultados escolares positivos que os faziam distinguirem-se dos seus colegas, do ponto de vista da performance acadêmica. Seu objetivo nesse estudo foi tornar relativas as expectativas ligadas à lógica da reprodução. $\mathrm{O}$ autor critica as teorias monofatoriais: tanto a da herança cultural como da diferenciação dos sistemas de valores segundo as classes. Como resultado, ele aponta que a percepção positiva da família a respeito da escola foi um aspecto verificado em todas as famílias. Salvas algumas restrições, os pais manifestaram uma boa impressão, principalmente dos professores. Ele conclui que o investimento familiar na escolaridade dos filhos pode servir como antídoto contra as determinações de classe, mas não pode ser visto de maneira compulsória e nem ser utilizado como justificativa do fracasso escolar.

Concluindo, todos os estudos colocam que a mobilização familiar para a escola, ao contrário do que se acredita no senso comum, não é um fator indispensável à escolarização das crianças, a ponto de ser exigido de forma compulsória. No caso das famílias populares, a imposição desse modelo de ajuda escolar gera, no mínimo, constrangimentos.

\section{V-As relações institucionais}

\section{1- Estrutura de poder na instituição escolar}

A escola, sendo uma instituição social, exerce mecanismos de controle como avaliação, comparação e julgamento do desempenho dos seus sujeitos, estando os espaços de troca entre estes permeados por essas questões (PEREZ, 2000). 
Vários estudos verificaram um padrão de verticalidade presente nas relações dentro da escola e formas autoritárias de exercício de poder (ANDRADE, 1986; CAMPOS, 1995; AQUINO, 1997; PEREZ, 2000). Campos (1995) aponta ainda que esse padrão prejudica o avanço da educação democratizadora, na qual o diálogo e os questionamentos são fundamentais para o desenvolvimento do processo educacional.

Lahire (1997) acredita que atualmente o poder sobre si mesmo substituiu o poder exercido pelos outros e pelo exterior, e que a escola exige do aluno autocontrole, capacidade de caminhar sozinho para apropriação do saber (aprender a aprender, o que constitui um dos slogans pedagógicos da modernidade). Assim, o poder que a escola exerce hoje está muito mais ligado a regras impessoais do que a um determinado detentor do poder. $\mathrm{O}$ autor conclui, então, que a escola não é simplesmente um lugar de aprendizagem de saberes, mas um lugar de aprendizagem de formas de exercícios de poder e de relações com o poder.

Também Aquino (1997), em estudo sobre a indisciplina, coloca que ela é observada nos dias atuais em escolas públicas e particulares, em todo o país, podendo ser uma indicadora do impacto proveniente do ingresso de um novo sujeito histórico. Ela pode estar sinalizando o ingresso de novas demandas e a necessidade, legítima, de uma transformação da escola em direção a um modelo menos autoritário e conservador. O autor ressalta ainda que a indisciplina não pode, sob hipótese alguma, ser avaliada como atributo psico(pato)lógico, como uma predisposição particular de um suposto "aluno-problema", "pois não se trata de uma anomalia individual e natural, mas do efeito de um trauma cujas raízes são irredutivelmente institucionais” (p.317).

\section{2- A relação professor-aluno}

Apesar de Aquino (1996) tratar especificamente da relação professor-aluno, ele investiga aspectos gerais da escola como a forma de funcionamento institucional, as formas de relação entre os atores sociais e a estrutura de poder nas relações institucionais, fazendo uma leitura da realidade que se aproxima da visão proposta no atual estudo.

A relação professor-aluno é descrita por ele como um palco de confrontos, uma vez que os lugares institucionais de aluno e professor não são complementares. Sua visão da relação professor-aluno é tratada a partir da noção de intersubjetividade, não 
havendo sujeitos constituídos a priori, nem professor nem aluno, mas sua constituição se dá no interior da relação

As relações interpessoais podem ser condensadas em três tipos básicos de vínculos: competição, cooperação e dependência. Especificamente no ensino, independente da modalidade de liderança, o vínculo primordial seria o de dependência, uma vez que o professor sabe mais que o aluno, devendo protegê-lo, julgá-lo, determinar a legitimidade dos seus interesses e definir a comunicação possível com ele.

No caso da relação professor-aluno, o vínculo é de submissão, porque o professor é portador do monopólio do tempo, do espaço e dos papéis da relação. É uma relação assimétrica, já que a competência do ensinante dá espaço ao exercício de um domínio que acontece por meio de instituições hierárquicas e coercitivas. Dessa forma, a relação é difícil, uma vez que se baseia na assimetria constitucional dos lugares institucionais de professor e aluno ${ }^{9}$. A função docente passa, inexoravelmente, pela função de exercício de poder e sujeição do aluno ao seu discurso.

O autor busca compreender, dessa forma, a natureza contratual da relação professor-aluno. Ele parte do pressuposto de que existe um contrato imaginário, e dessa forma institucional, que entrelaça os dois atores sociais, e que está em permanente (re)estruturação.

Aquino (1996, p.147) sugere ainda que o cenário escolar parece pautar-se em esquemas de contra-controle:

[...] a educação atitudinal (disciplinar, moral e/ou psicológica) parece ocupar os principais territórios sobre os quais sedimentam os vínculos no âmbito escolar - o que não deixa de nos causar perplexidade, uma vez que pouquíssimos foram os momentos em que se pôde entrever claramente a premissa de laicidade do ensino.

Ele verificou que a indisciplina do aluno perpassa invariavelmente o imaginário de professores e que o trabalho docente é representado prioritariamente como ordenação, controle e/ou supressão da agitação em sala de aula. Por outro lado, os alunos também colocam os professores numa camisa de força atitudinal, exercendo um contra-controle à conduta docente. Ele aponta, ainda, que tanto o professor quanto o

\footnotetext{
${ }^{9}$ Existe aí o pressuposto de que lugar discente é lugar vazio (de ignorância) e acaba-se esbarrando na concretude do aluno que o ocupa, que carrega saberes anteriores e paralelos.
} 
aluno utilizam a mesma estratégia: o olhar avaliador sobre o lugar alheio, a partir do próprio lugar.

Também Andrade (1986), ao realizar um estudo etnográfico numa escola pública, verificou que a relação professor-aluno era marcada pela estigmatização e o uso de profecias auto-realizadoras, que acabavam servindo como "arma adicional do professor na luta contra os alunos que não se submetiam facilmente. Essa estigmatização é aceita e referendada pela supervisão (...)" (p.214).

\section{3- A relação entre a escola e a família}

Campos (1995), em estudo com famílias de classe social baixa, verificou que a escola legitima, muitas vezes, as desigualdades presentes na nossa sociedade, através do lugar de poder que ocupa junto às famílias. Nesses casos, a relação fica difícil, pois os pais se sentem desconsiderados e, quando chamados à escola, imaginam que é sempre para serem criticados.

A autora observou também uma presença acentuada na escola de um pensamento preconceituoso e estereotipado com relação às famílias. Por sua vez, essas incorporam, na maioria das vezes, a culpa que lhes é delegada pela incapacidade de seus filhos, tomando para si o fracasso, o que reforça o processo de desvalorização subjetiva.

Segundo Perez (2000), a relação entre a família e a escola está pautada na mútua transferência de responsabilidades. Ela verificou que os contatos entre pais e professores ocorriam primordialmente em função de problemas comportamentais das crianças, sendo a indisciplina o tema que justificava esses encontros.

Carvalho e Vianna (1994) lembram que, especialmente nos meios populares, onde as famílias são consideradas incapazes de formar bem os seus filhos, o Estado é chamado a interferir para garantir proteção, saúde, educação, disciplina e higiene para essas crianças. Assim, muitas das questões, pelas quais os pais são chamados à escola, tratam muito mais da delimitação de poderes sobre a criança do que da discussão sobre métodos de educação.

Elas afirmam também que falar em relação escola-família é usar um termo enganador, porque o que acontece na maioria das vezes são encontros entre os agentes escolares e as mães, uma vez que as mulheres são responsáveis pelos cuidados básicos com as crianças em nossa sociedade. 
Segunda as autoras, a escola se utiliza do sentimento de culpa que toda mãe traz dentro de si, manipulando-o, levando a que todos os problemas sejam atribuídos às esferas individuais de cada uma. A escola cobra que a mãe esteja presente, desde que essa presença não invada questões de decisão dentro da escola e seja restrita à dimensão doméstica. As mães deveriam atuar como mães de alunos individuais, representantes dos interesses particulares dos seus filhos (CARVALHO; VIANNA, 1994).

Assim, as autoras buscam compreender a relação entre professoras e mães a partir do ponto de vista da criança, que está a meio caminho entre o poder da família (privado) e o poder da escola (público). Ao mesmo tempo em que ela é o centro da família e a maternagem é vista como reduto da vida privada, a criança também é vista como cidadã, o futuro trabalhador e o futuro da nação.

No estudo que realizaram, Carvalho e Vianna (1994) observaram uma disputa de poder entre mães e educadoras, sendo a escola referida por ambas como segundo lar, cada uma reclamando a sua maneira o que lhe cabe nessa relação. A mãe reclama seu poder sobre o filho, o que lhe confere poderes sobre a escola. Por outro lado, a professora pretende manter seu espaço reservado, uma vez que ela tem mais poder na sala de aula do que em sua própria casa. O que acaba ocorrendo, então, é ataque e culpabilização mútuos (CARVALHO; VIANNA, 1994).

Um outro aspecto verificado no estudo é que os encontros são mais evidentes quando o trabalho com a criança é colocado no centro das atenções. Quando a função pedagógica da instituição está clara, acontecem menos conflitos com a família.

Assim, a partilha das responsabilidades sobre a criança é, ao mesmo tempo, centro de desencontros, mas também um ponto forte para a aproximação, pois professoras e mães têm muito em comum: sonhos, horizontes, histórias.

"Cada vez que uma educadora ou mãe de aluno conseguia colocar-se na posição da outra ou perceber a situação a partir deste ponto de vista, a distância costumeiramente estabelecida entre elas se desfazia e a identificação era construída" (CARVALHO; VIANNA, 1994, p. 156).

\section{VI - As representações dos professores sobre o aluno e sua família}

Campos (1995) baseou sua pesquisa em estudos realizados a partir da década de 80 que, ao invés de colocar as causas do fracasso escolar nas práticas inadequadas do 
professor ou nas deficiências da criança ou carências familiares, apontam como causa uma estrutura mais ampla: a forma como os países capitalistas lidam com a educação e a maneira como a ideologia dominante determina esse processo. Com a intenção de investigar o fracasso escolar sob esse enfoque, a autora criou um projeto chamado “Ação Psicológica na Comunidade: A Questão do Fracasso Escolar", onde atuou em duas comunidades de Piracicaba, caracterizadas por uma situação de carência de recursos materiais e população predominantemente de migrantes, provenientes do meio rural. O objetivo do seu trabalho foi identificar as concepções que reproduzem e reconstróem os sentidos veiculados pela escola na relação com os pais e o lugar que essas concepções ocupam na vida cotidiana desses pais.

Através de diários de campo, entrevistas gravadas junto às escolas e junto às famílias, buscou-se a verificação das concepções sobre o fracasso escolar na instituição escola e na instituição família. O trabalho foi realizado em três níveis: grupos de crianças apontadas pela escola como possuindo problemas de aprendizagem, grupos de reflexão com os pais dessas crianças e grupos de professores.

O trabalho com os pais, na verdade com a quase absoluta maioria de mães, foi dificultado pela inconstância na participação e se caracterizou por grupos de reflexão. $\mathrm{O}$ trabalho com as crianças se caracterizou por intervenções grupais, utilizando atividades lúdicas e acadêmicas. Junto às escolas, foi inicialmente realizada uma coleta de informações acerca do cotidiano institucional, buscando diagnosticar as concepções existentes sobre os problemas educacionais que atingem as crianças que freqüentam essa instituição. Em seguida, montou-se um grupo de professores, que mostraram resistência em participar das reflexões e discussões do projeto. Como eficaz consideravam a intervenção direta junto às crianças que identificavam como problemáticas. Mesmo após a intervenção, observou-se a repetição de alegações segundo as quais as crianças não são capazes de aprender porque são pobres, filhos de analfabetos, de pais separados e vão para a escola sem comer. Fica claro, então, que na visão dos professores o ideal de família corresponde à estrutura tradicional: pai, mãe e filhos em convivência harmônica.

Também Gomes (1994) indica que a escola tende a responsabilizar exclusivamente a família pelos problemas de aprendizagem e disciplina dos alunos, atribuindo-lhe o rótulo de desestruturada. Ela afirma que por trás desse discurso tem-se um modelo de família estruturada ideal (que a autora chama de família pensada), baseada num modelo de família nuclear burguesa, e as famílias desviantes desse padrão 
são consideradas incompetentes. A família vivida, "real", apresenta as mais variadas estruturas e modos de relações, mas essas alternativas não são vistas como novas ordens e sim como caos, a causa de todas as dificuldades das crianças.

Sigolo e Lollato (2001) realizaram um estudo sobre as concepções de pais e professores sobre a criança, o ambiente familiar e escolar e as possíveis relações que esses diferentes contextos podem estabelecer. Elas verificaram que os professores tinham uma visão idealizada sobre os alunos e, quando estes não correspondiam ao que deles era esperado, seja em termos de comportamento ou aprendizagem, a culpa passava a ser atribuída à família, que era vista como desinteressada. Assim, elas concluem que o baixo rendimento escolar e a indisciplina são normalmente atribuídos ao descaso familiar em relação à escolaridade. Segundo as autoras, além de desqualificarem a família, os professores costumam atribuir a culpa das dificuldades cotidianas a fatores externos, não refletindo sobre as próprias percepções e concepções que conduzem a prática pedagógica.

Nesse estudo, os professores não mostraram conhecer a fundo os conteúdos relativos ao contexto familiar, apesar de acharem importante o contato com a família. Eles faziam questão, sim, de que os pais mantivessem a repreensão em casa para que houvesse uma continuidade entre a educação dada na escola e aquela vivenciada na família.

Carvalho e Vianna (1994) observaram também que dificilmente as educadoras tinham um discurso elogioso ou de aprovação em relação às mães. Ou essas pecavam por excesso de carinho e proteção, o que está cristalizado no estereótipo de supermãe, ou eram criticadas por ausência, abandono e negligência. Segundo as autoras, as educadoras desqualificam a competência da mãe na educação das crianças para reafirmar seu próprio papel profissional, que está precariamente estabelecido e é sempre colocado em cheque.

Um outro aspecto importante observado nesse estudo é que as educadoras não consideravam os condicionantes sociais quando se remetiam às mães, que eram vistas de maneira individualizada e circunscrita à esfera íntima. $\mathrm{O}$ fato de não conseguirem cuidar adequadamente dos filhos era sempre visto como um problema moral, normalmente atribuído ao núcleo familiar.

Além disso, as educadoras teciam exigências de acompanhamento das mães com relação aos filhos, estabelecendo o horário para comparecerem a reuniões e criticando 
abertamente as mães ausentes. Elas partiam, assim, do pressuposto de que as mães dispõem de tempo integral para se dedicar aos filhos, o que corresponde ao modelo idealizado de família: casal monogâmico, estável, com divisão clara dos papéis entre os gêneros.

Nas falas das educadoras foram comuns os relatos do tipo "tem que se barrar as mães, colocar limites nas mães, acabar com seus palpites", sendo a escola defendida como um território que não deve ser invadido por estranhos. Por outro lado, as educadoras também se queixavam de que as mães não acompanhavam devidamente os filhos nas lições de casa.

“As educadoras sentiam-se profundamente ameaçadas pelas participações ativas das mães em reuniões e na tomada de decisões e até mesmo pela sua simples presença dentro da escola" (CARVALHO; VIANNA, 1994, p. 141).

Um outro aspecto observado é que as professoras, ao serem solicitadas a falar sobre os alunos, respondiam a respeito das mães, não mencionando as próprias crianças, os pais, a sociedade, as condições de vida, a escola, nem o sistema escolar. Isso indica que o papel de mãe está no alvo dos julgamentos e avaliações realizados na escola.

Também Perez (2000) observou que os professores normalmente transferiam a responsabilidade da aprendizagem e disciplina aos pais, acusando-os de falta de orientação e incentivo na escolaridade dos filhos.

Andrade (1986) obteve resultados parecidos ao realizar um estudo etnográfico numa escola pública. As famílias dos alunos eram vistas pelos professores como ineficientes para transmitir as concepções de mundo adequadas à criança. Assim, observaram-se julgamentos baseados em estereótipos que identificavam a pobreza com a degradação de valores morais. Na prática docente, as ações disciplinadoras eram privilegiadas, às vezes, até em detrimento de outras práticas pedagógicas, com o objetivo de formar hábitos salutares e transmitir valores nobres e superiores às crianças.

\section{VII - As representações dos pais sobre a escola}

Cruz (1997) pesquisou a representação de escola em pais de crianças da $1^{\mathrm{a}}$ série e verificou que a grande maioria das famílias dá grande importância à escolarização dos filhos, sendo essa a maneira como seus membros podem ascender na escala social. No entanto, no decorrer do ano letivo, as famílias começam a ficar desesperançosas de que 
esse fato realmente venha a acontecer. As crianças vão para a casa com tarefas que não sabem fazer, e as cobranças da escola são cada vez mais difíceis para os pais. Quando as mães procuram a escola para pedir ajuda, a culpa de todo fracasso lhes é atribuída. Como não percebem a possibilidade de enfrentar coletivamente a escola e obter mudanças no seu funcionamento, elas passam a tentar, de todas as maneiras, modificar os filhos. Afinal, abrandar a natureza dos filhos acaba sendo a única estratégia possível. Assim, para as crianças, os pais são vistos como aliados da escola, uma vez que não as protegem das situações de injustiça ou agressão ocorridas. A autora coloca ainda que a submissão às normas da escola, que acaba sendo recomendada pelas mães, é captada com bastante clareza pelas crianças.

Um outro aspecto observado no estudo é a insatisfação das mães com relação às reuniões de pais e mestres. Elas mostram indignação frente à forma humilhante como são conduzidas essas reuniões, mas não percebem o caráter de intimidação que ali ocorre, através da responsabilização dos pais, que são repreendidos publicamente.

Perez (2000), ao estudar as representações de pais acerca da escola, obteve como resultado o fato de as reuniões de pais e mestres, único espaço instituído para as trocas entre família e escola, serem vistas pelos pais como uma obrigação a ser cumprida. A autora coloca ainda que a escola não foi pensada para atender a população desfavorecida econômica e socialmente e que na instituição escolar a pobreza normalmente é tratada como determinante que impede a realização de um trabalho educacional efetivo. A autora observou também uma preocupação dos pais com relação ao rendimento escolar dos filhos, além de verificar que os pais realmente acreditam que a escola é um espaço educativo compensatório para suas limitações. Assim, eles manifestavam comportamentos passivos e conformistas com relação ao funcionamento escolar.

Também Sigolo e Lollato (2001) apontam que os pais criticam os momentos de reunião e o fato de as professoras não tratarem de assuntos de interesse familiar. Por outro lado, as condições precárias de trabalho na escola pública fazem com que os pais admirem ainda mais a professora, por ter capacidade de desenvolver tão bem seu trabalho em condições adversas. Os relatos dos pais revelam dificuldades de refletir sobre as vivências ocorridas na escola, o que pode ser causado pela naturalização do cotidiano.

Quanto à relação entre professor e aluno, os pais apontaram a afetividade como sendo essencial nessa relação, valorizando a imposição de respeito pela professora, 
mesmo que isso ocorra de forma rígida. A professora é vista por eles de forma idealizada e quando emite uma opinião, essa é incorporada por eles da seguinte maneira: se escutam elogios, eles se sentem satisfeitos, senão, eles passam a introjetar aquilo que ouvem. Assim, foi observada uma atitude de respeito dos pais com relação à professora, além da valorização de uma relação baseada em afetividade e autoridade, para que haja harmonia do grupo e desenvolvimento integral dos filhos.

Também buscando compreender as representações dos pais acerca da escola, Zago (1998) realizou um estudo sobre a formação de percursos escolares, privilegiando a história familiar, a situação escolar, acontecimentos que marcaram o curso de escolarização dos filhos, a relação da família com a escola e os projetos de mobilização dos pais em termos escolares. A autora buscou apreender como acontece no cotidiano a exclusão do sistema de ensino e qual o significado da educação formal para os pais. Ela aponta que as realidades sociais e econômicas dos sujeitos foram muito próximas, caracterizadas pela falta crônica de recursos, instabilidade de emprego, uma luta contínua para resolver problemas imediatos de sobrevivência e moradia, uma mobilidade geográfica acentuada, além da introdução precoce dos filhos no trabalho.

Dessa forma, ficaram evidentes as dificuldades de responder às solicitações da escola em termos de material escolar, as dificuldades de acompanhar o currículo da escola e a própria desmobilização depois de repetidos insucessos escolares. A autora ressalta que é importante evidenciar as condições econômicas da população estudada, mas elas não determinam mecanicamente os comportamentos escolares nem dos pais e nem dos filhos. Mesmo nas famílias mais pobres, observam-se comportamentos de resistência à exclusão precoce da escola e também à inserção das crianças no mundo do trabalho.

A autora aponta, ainda, que as famílias não são espectadoras passivas frente aos mecanismos de exclusão e inclusão escolar e se mostra contrária à tese da carência cultural difundida nos anos 60 e 70. Apesar de todas as dificuldades, os pais mantêm uma relação positiva com a educação escolar. A escola é a única maneira que eles possuem de vislumbrar uma integração social e profissional dos filhos, e as ambições sobre o futuro dos filhos são limitadas, mas representam sempre uma superação das condições sociais dos pais.

Além disso, os pais esperam da escola que os filhos aprendam os conteúdos para que possam lidar com as situações cotidianas da vida. A escola também representa um 
lugar de guarda dos filhos e de continuidade dos valores transmitidos pela família. Para os pais, instrução e socialização são inseparáveis. Por isso exigem do professor que mantenha uma autoridade sobre os alunos e que seja exigente com relação aos trabalhos escolares.

No entanto, a expectativa de continuidade do estudo dos filhos depende das condições reais de vida. Assim as projeções com relação ao futuro às vezes são pouco ambiciosas e vagas, mesmo o estudo sendo valorizado.

A representação dos pais sobre a escola foi investigada, ainda, em dois estudos (ANDRADE, 1986; CHECHIA, 2002) realizados dentro do referencial do Sociodrama Educacional e com relação aos quais o atual estudo é uma continuidade.

Um deles foi realizado por Andrade (1986), através de um estudo etnográfico, com o objetivo de lançar luz ao fenômeno da reprovação escolar em alunos da primeira série de uma escola pública de periferia. Foram realizadas observações participantes, entrevistas semi-estruturadas e contatos informais com os pais, professores, funcionários e crianças. $\mathrm{O}$ autor considerou como fonte de investigação o contexto familiar e social dos alunos, o seu potencial cognitivo e, por último, a dinâmica intraescolar. O motivo do estudo foi compreender o aluno repetente da $1^{\mathrm{a}}$ série do ensino primário na situação de campo, ou seja, na sua vida cotidiana, dentro e fora da escola. $\mathrm{O}$ fenômeno estudado foi interpretado a partir das suas relações com o contexto social mais amplo, e as informações de campo foram relacionadas a outras informações relativas à macro-estrutura social. Dessa forma, a dimensão histórica esteve presente, e a educação formal foi definida como uma instituição que se articula tanto com o Estado, no sentido estrito, quanto com a sociedade civil. Além do estudo da dinâmica intraescolar, o autor realizou um estudo complementar, fazendo uma contextualização histórica e social das famílias e dos alunos. Assim, foram realizadas entrevistas semiestruturadas nos lares dos alunos, com seus pais e responsáveis.

A análise desses dados revelou que $70 \%$ das famílias de alunos repetentes eram migrantes, provenientes de zonas rurais. Além das entrevistas foram realizadas observações acerca das condições de subsistência dos familiares e outras situações cotidianas que envolviam a vida do aluno. A maioria dos pais entrevistados apresentava um padrão de resignação e conformismo e um apelo para entidades superiores como a única forma de superar a situação de carência em que viviam. Poucos tinham uma visão mais crítica, que denunciava explicitamente as injustiças sociais das quais eram vítimas. 
A maioria deles atribuía a causa dos problemas na escola às dificuldades internas da criança, do tipo deficiência orgânica ou mental. Eles se referiam a deficiências externas à criança, apontando a falta de alguém em casa para ajudá-la e também a deficiências do ensino rural prévio. As críticas dos pais com relação à escola levavam em conta a negligência da escola no trato com os alunos. Outra crítica referiu-se ao constante remanejamento dos alunos. E a terceira crítica referiu-se às negligências dos professores em suas atividades em sala de aula. É importante notar que apenas 7\% das famílias apresentaram essas críticas à escola. 43\% dos entrevistados responderam genericamente que a escola e os professores eram bons, e outros 50\% não responderam, dizendo não serem capazes de fazê-lo, por não estarem acompanhando de perto a vida escolar dos filhos.

Com relação aos professores, $45 \%$ declararam gostar do professor dos filhos e $25 \%$ criticaram seu desempenho. As críticas tinham a ver principalmente com a relação professor-aluno, além das negligências dos professores no cumprimento de suas responsabilidades didático-pedagógicas.

Em relação à importância dos estudos, $86 \%$ dos pais o colocaram como sendo primordial, estando dispostos a qualquer sacrifício para que o filho pudesse estudar. Quanto à justificativa da necessidade do estudo, o autor encontrou as seguintes respostas: melhores condições de emprego, necessidade de estudo para uma vida mais fácil e o estudo como a única herança que os pais poderiam deixar para os filhos. Ou seja, o autor afirma que o estudo para esses pais representa a única forma de ascensão social.

Um outro resultado importante desse estudo é que os familiares entrevistados atribuíam à criança ou a si mesmos as dificuldades escolares dos filhos, ou seja, interiorizaram a ideologia do dom, que oculta o fracasso do sistema escolar público com relação às classes subalternas da sociedade.

Por fim, as conclusões gerais do trabalho indicam, em primeiro lugar, o fato de que $75 \%$ das famílias dos alunos repetentes tinham rendimentos econômicos inferiores à renda mínima per capta legal, o que os coloca dentro dos índices de populações marginais. Dessa forma, os alunos pertencentes aos segmentos mais pobres da sociedade são os que menos chances têm de progredir na escola. Por outro lado, os dados apontaram que não há razão para afirmar que essa população tenha algum grau de desadaptação social. Mas quanto a sua visão de mundo, observou-se uma postura de 
resignação com as condições em que vivem. A hipótese da carência de pré-requisitos necessários à escolarização pareceu, nesse estudo, improcedente.

O segundo estudo do Grupo de Pesquisa em Sociodrama Educacional sobre as representações dos pais sobre a escola foi realizado por Chechia (2002). A autora investigou, por meio de entrevistas individuais, as representações de dois grupos de pais, aqueles cujos filhos eram considerados como tendo sucesso escolar e aqueles cujos filhos obtinham insucesso escolar.

A autora observou que os pais de alunos com sucesso escolar apontaram genericamente que a "escola é boa", mas mostraram, ao mesmo tempo, uma insatisfação com o ensino público. Essa contradição pareceu ser decorrente do medo dos pais de revelar suas verdadeiras opiniões sobre a escola.

Já os pais de alunos com insucesso escolar mostraram atribuir aos filhos toda a responsabilidade pelas dificuldades encontradas no processo de ensino-aprendizagem. Esses pais também mostraram uma percepção positiva sobre a escola, não se contrapondo a ela abertamente.

A autora verificou ainda que foi unânime a ocorrência de auxílio dos pais nas tarefas escolares, independente do sucesso dos alunos. No entanto, os pais de alunos com insucesso mostraram dificuldades em atingir seus objetivos devido a uma falta de estratégias. Eles mostraram culpar-se pela incapacidade de ajudar os filhos.

Com relação à participação no dia-a-dia escolar dos filhos, Chechia (2002) verificou que ambos os grupos de pais mostraram acompanhar o processo dos filhos na escola, sendo que os pais de alunos com sucesso tendiam a se ater mais ao processo avaliativo (notas), mostrando-se vigilantes quanto ao desempenho dos filhos. Já os pais de alunos com insucesso escolar relataram uma presença ativa na escola, mas mostraram ter uma relação difícil com a questão do desempenho escolar.

\section{VIII - Justificativa}

Samartini (1995) afirma que os pais percebem os resultados do trabalho da escola e sabem reconhecer se o ensino é bom ou ruim. Portanto, eles são sujeitos privilegiados para estar avaliando a escola. Além disso, com a aproximação cada vez maior entre essas duas instituições que são responsáveis pela socialização da criança, a 
família e a escola, vários autores vêm apontando a necessidade de uma compreensão mais aprofundada sobre as maneiras como esse encontro está ocorrendo.

Nessa mesma perspectiva, Andrade (1986) aponta que a compreensão das camadas populares é uma conquista recente por parte da escola, mas ainda carente de muitas reformulações para que seja realmente efetiva. É necessário que se explicite os conflitos e os antagonismos presentes na prática cotidiana da escola, revelando também a estrutura social em que se insere, sem deixar de considerar o movimento instituinte que acontece em seu interior. Segundo o autor, é importante,

[...] sem dúvida, a obtenção das avaliações dos pais ou responsáveis sobre as ações da escola estabelecendo, com isso, uma alça de realimentação para o processo em implementação, e ainda, propiciando a eles um espaço para o exercício de suas ações controladoras e fiscalizadoras da instituição escolar (ANDRADE, 1986, p. 219).

O atual estudo visa contribuir nessa direção, buscando lançar um pouco mais de luz às práticas realizadas nos âmbito escolar e familiar, trazendo à tona reflexões acerca das ações cotidianas e da relação entre os atores sociais, presentes no campo de pesquisa. Buscar-se-á apreender, então, as representações de pais sobre a escola pública, uma vez que eles representam, muitas vezes, o olhar instituinte ${ }^{10}$, que enxerga o instituído com um pouco mais de distância do que os outros participantes do cotidiano escolar. Acredita-se, portanto, que eles são atores privilegiados quando o assunto é a escola, porque são usuários do serviço, tendo um ângulo de visão diferenciado.

Além disso, eles vêm sendo cada vez mais solicitados a participar da escola, mas sua opinião normalmente não é ouvida. Vale ressaltar, por fim, a ênfase de alguns autores à importância de lhes serem dada voz (ANDRADE, 1986; SAMARTINI, 1995; PEREZ, 2000).

\footnotetext{
${ }^{10}$ Guirado (1987) ao estudar as instituições, coloca uma distinção entre os termos instituído e instituinte. “O primeiro significa o que está estabelecido; é o caráter de fixidez e cristalização das formas de relação. O segundo significa o movimento de criação: é a capacidade de inventar novas formas de relação.(...) É ele que garante, em última instância , a possibilidade de mudança" (GUIRADO, 1987, p. 30).
} 


\section{IX - Objetivos do atual estudo}

\section{1 - Objetivo Geral}

De acordo com a literatura, a relação entre a escola e as famílias parece estar ocorrendo como mais uma prática de dominação, sendo claras as raízes ideológicas presentes na história dessa aproximação. Por outro lado, essa relação vem sendo incentivada, ocorrendo de maneira crescente nas escolas, já que é vista como um dos requisitos essenciais a uma escolarização bem sucedida. Então, o objetivo do atual estudo é investigar a forma como a relação família-escola está de fato ocorrendo para os pais. Como eles enxergam e como vivenciam a relação com a escola dos filhos? Essa é a questão sobre a qual o atual estudo buscará lançar um pouco mais de luz.

\section{2- Objetivos Específicos}

A) Compreender o contexto sócio-histórico das famílias entrevistadas;

B) Conhecer o contexto geral da escola;

C) Verificar semelhanças e diferenças entre as representações e as vivências dos pais;

D) Levantar as percepções dos pais sobre a escola, sobre os professores e sobre o significado da educação formal;

E) Identificar práticas intituídas e instituintes presentes no coitidiano escolar. 


\section{CAPÍTULO II - METODOLOGIA}

"Cuidar das coisas implica ter intimidade, senti-las dentro, acolhe-las, respeita-las, dar-lhes sossego e repouso. (...) É entrar em sintonia com, auscutar-lhes o ritmo $e$ afinar-se com elas."(Leonardo Boff, Saber cuidar, p. 96)

\section{I - Abordagem teórico-metodológica}

O atual estudo está ancorado, teórica e metodologicamente, ao modelo adotado pelo grupo de pesquisas em que está inserido, o GEPSEd (Grupo de Estudos e Pesquisa em Sociodrama Educacional "Jacob Levy Moreno"). Para definir o grupo serão utilizadas as próprias palavras de seu coordenador:

O Sociodrama Educacional se caracteriza como uma linha de pesquisaação de uma Psicologia Escolar Institucional que se propõe ao estudo das relações humanas nesse contexto. Além do referencial de uma Psicologia Institucional, utiliza estratégias de pesquisa qualitativa, de cunho sociopsicodramático, objetivando contribuir para o sucesso escolar, entendido como apropriação por parte do Sujeito do conhecimento acumulado pelo Homem, enquanto ser genérico. Para alcançar tais metas, busca a compreensão das interações sociais que constituem o cotidiano destas instituições, enfocando-as a partir da concepção de papéis como estruturas, segundo as quais os diferentes integrantes da instituição pautam suas relações. (ANDRADE, 2004, p.3-4).

Dentro dessa perspectiva, o panorama de investigação do atual estudo pode ser verificado a seguir:

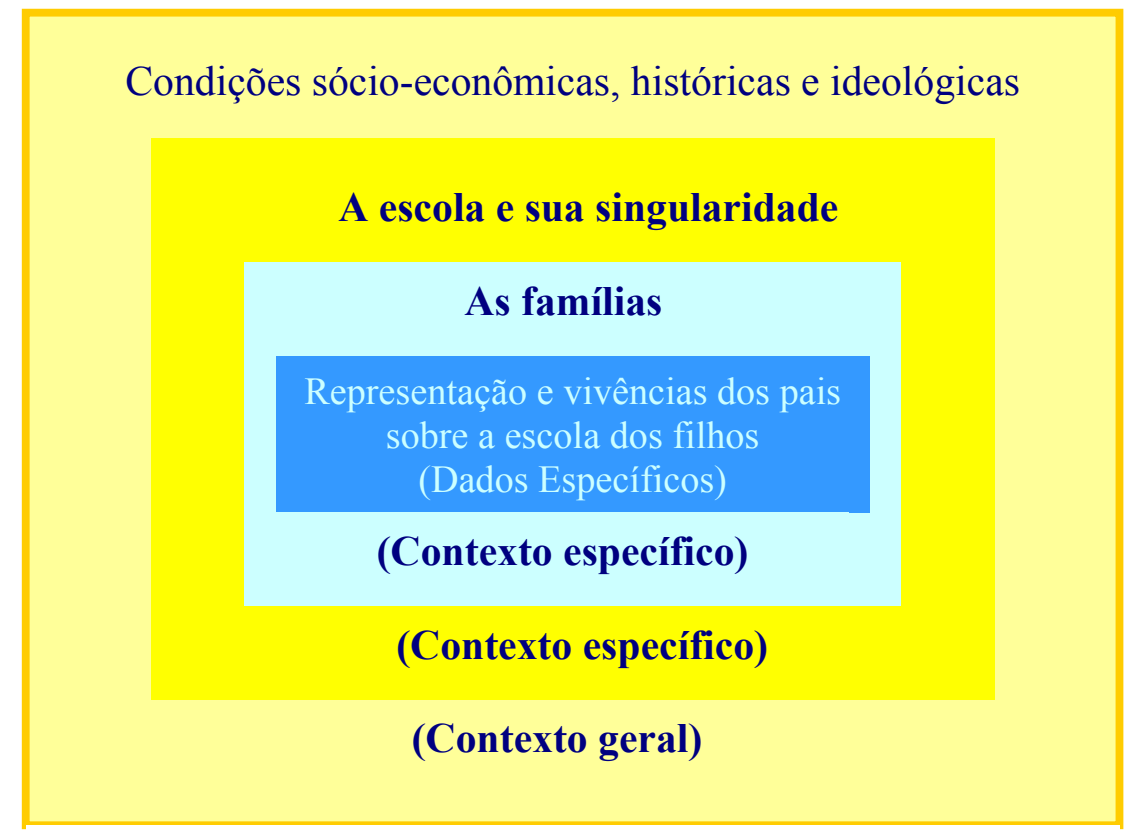

Figura 2. Panorama de investigação do atual estudo 
Para a investigação do contexto específico (bairro, escola, família) utilizou-se a abordagem etnográfica, que consiste numa investigação sistemática das situações do cotidiano escolar, levando em conta seu contexto e sua dinâmica. Por meio da etnografia, obtém-se uma compreensão aprofundada sobre a visão que os sujeitos sociais constroem acerca de si mesmos e do meio social que os circunda, uma vez que ela propõe a apreensão da totalidade onde se insere o objeto da pesquisa. Investiga-se o contexto mais amplo, ao mesmo tempo em que se busca retratar os diferentes pontos de vista dos vários grupos sociais que participam do cotidiano institucional. (ANDRÉ, 1994)

Esse enfoque foi adotado por permitir uma apreensão ampla e integrada das situações vivas da unidade social complexa que é a escola. A característica principal dessa metodologia é a necessidade do contato direto do pesquisador com a situação pesquisada: direção da escola, pessoal técnico-administrativo, pais e professores, podendo necessitar, ainda, de uma análise da documentação que afeta direta ou indiretamente o funcionamento da escola.

Para a apreensão do cotidiano escolar foi realizada a Observação Participante, recurso metodológico apontado por vários autores (ANDRADE, 1986; ANDRÉ, 1994; EZPELETA \& ROCKWELL, 1989) como um eficiente método de pesquisa de campo, podendo ser utilizado em associação com outros. A questão que se coloca é, então, que enquadre teórico o pesquisador adota como lente através da qual ele vai ao encontro da realidade? O que observar na escola, uma vez que as categorias sociais tradicionais são rígidas demais para dar conta do cotidiano institucional?

Por outro lado, Ezpeleta \& Rockwell (1989) fazem uma crítica às observações que se apóiam em categorias do senso comum, não atingindo, tampouco a complexidade de seu objeto de estudo. Faz-se necessário, portanto, que se delimite o enquadre teórico que norteia a observação participante.

Essas autoras retomam a idéia da construção social da escola, apontando que sua história é tecida de maneira local, ressaltando a necessidade de se conhecer as formas particulares de seu engajamento ao contexto social mais amplo.

Assim, como a instituição escolar é atravessada pela história e pelo cotidiano, ela é um espaço onde ocorrem mecanismos de dominação e resistência, de controle e apropriação, sendo seus agentes, sujeitos histórico-sociais. Reprodutores, enquanto vítimas do determinismo social, e produtores, na medida que em há uma resistência aos mecanismos de controle. 
Nesse sentido, os movimentos comunitários e reinvidicativos, as diferenças étnicas, o peso relativo da Igreja, entre outros, são aspectos a serem investigados para que se possa verdadeiramente conhecer uma escola. Vale notar que esses aspectos não constam de sua história formal e documentada.

Cabe ao pesquisador reconstituir essa história não-documentada, observando os conteúdos ocultos às prescrições técnicas e administrativas e colhendo relatos orais, por meio dos quais se pode recuperar a memória coletiva. "Reconstruímos o que pode ser convergente, o que pode ser divergente ou contraditório, nas diversas formas de existir da escola.(...) Conservar a heterogeneidade, uma das características mais notáveis de qualquer escola.” (EZPELETA \& ROCKWELL, 1989, p.25 )

Essa maneira de apreender o conteúdo social do conjunto de atividades cotidianas só é possível como produto de uma construção histórica que deve ser compreendida. Assim, as incongruências observadas na instituição escolar adquirem sentido como resultado dos processos de apropriação, reprodução e resistência. "As tramas reais se armam a partir de pequenas histórias, em que se renuncia e se reordena a continuidade e a atividade escolar” (EZPELETA \& ROCKWELL, 1989, p. 29).

Dessa forma, segundo as autoras, o que se deve perseguir, ao realizar a observação participante na escola, é a presença da história e do Estado na instituição, em suas formas implícitas. Trata-se de conhecer sua gênese social a partir dos sujeitos individuais que a vivenciam diariamente. Assim, esse método possibilita o conhecimento do funcionamento institucional, revelando alguns conflitos e encontros entre os vários segmentos e pessoas presentes no cotidiano escolar.

Os dados específicos da pesquisa, as representações e vivências de pais, foram obtidos através de entrevistas individuais de profundidade e por meio de entrevistas em grupo focal. As entrevistas de profundidade foram realizadas segundo um procedimento que consistia basicamente no entrevistador abordar o tema e em seguida dar um tempo para o entrevistando passar por um processo de associação livre, onde as idéias suscitadas pela questão seriam expostas. Só então os temas deveriam ser discutidos, aprofundando o material trazido inicialmente.

Carraro (2002) utilizou essa estratégia em seu estudo, definindo-a como uma adaptação de uma técnica padrão utilizada na evocação, enunciação e verificação de material para construção de escalas de atitudes. No entanto, segunda a autora, 
[...] na construção de escalas a terceira etapa, denominada "verificação", se destina a colher apenas uma confirmação do sentido e significado que o entrevistado atribuiu à sua enunciação[...]. No nosso caso, desenvolvemos uma ampliação dos propósitos desta última etapa, de tal forma que podemos considerar que as duas primeiras nada mais significam senão um processo de "aquecimento", tal como nas sessões de Psicodrama, para a realização da entrevista propriamente dita, que se concretiza na terceira etapa. (CARRARO, 2002, p. 58-59)

Ainda, para que a entrevista ganhe profundidade, o pesquisador deve criar um clima de confiança para que a pessoa possa falar, liberada dos medos e constrangimentos comuns. “(...) mantendo uma atitude espontânea e natural, a entrevista resultante poderá ser muito valiosa em termos de informações obtidas" (MARTINS \& BICUDO, 1994, p.56).

As entrevistas em grupo focal são definidas por Vaughn, Schumm e Sinagub (1996) como um eficiente modo de averiguação das perspectivas dos sujeitos, sendo útil na obtenção de respostas relativas às suas experiências. Nesse sentido, todos os participantes do grupo devem ter vivido situações similares concretamente.

O objetivo dessa abordagem é conseguir uma conversa branda e livre, mas que toque profundamente no tópico selecionado. Os autores apontam que esse método tem sido utilizado para investigar os motivos latentes, por detrás daqueles manifestos, uma vez que as pessoas podem refletir e interpretar os acontecimentos.

\footnotetext{
A meta é conduzir uma discussão interativa que elicie uma maior e mais profunda compreensão das percepções, crenças, atitudes e experiências, a partir de múltiplos pontos de vista e documentar o contexto de onde essa compreensão foi derivada. (VAUGHN, SCHUMM \& SINAGUB, 1996)
}

Segundo esses autores, são muitas as razões para a utilização das entrevistas em grupo focal no contexto da pesquisa acadêmica, pois é um método versátil, podendo ser utilizado tanto em estudos quantitativos, quanto qualitativos. Além disso, a entrevista em grupo focal oferece oportunidade para um contato direto entre os sujeitos, possibilitando uma coleta de dados distintos daqueles conseguidos por meio de entrevistas individuais.

A aplicação desse método em pesquisas é importante quando se busca o desenvolvimento de uma hipótese, ou quando se pretende desenvolver um instrumento, 
para complementar a coleta de dados e avaliar os procedimentos já administrados, ou ainda para aprofundar questões e interpretar descobertas anteriores.

Acredita-se que o formato grupal favoreça que o drama coletivo tome corpo e, por isso, ele tem muito a contribuir no sentido de apreender aspectos profundos, os nãoditos, pois as vivências pessoais encontram eco na coletividade e, assim, ganham legitimidade.

A teoria utilizada na condução dos grupos foi o Psicodrama. Nessa abordagem, três contextos fundamentam a sessão: o contexto social, o grupal e o dramático. Acredita-se que quando as pessoas chegam ao grupo, trazem consigo as situações vividas nas suas matrizes originárias, sendo este o contexto social. No interior do grupo, essas vivências são recompostas em conflitos, oposições e alianças entre seus membros, formando assim uma matriz sociométrica, a qual configura o contexto grupal. É nesse contexto que o drama coletivo começa a se evidenciar, ainda que de maneira difusa, até que tome uma forma.

No entanto, como o drama não é na realidade originário desse contexto, utilizase o espaço do "como se" para revelá-lo; abre-se o palco, fazendo surgir o contexto dramático. No “como se", a situação vivida em sociedade e no grupo aparecem sobrepostas, o real e o imaginário se misturam e o drama aparece circunscrito na história de um dos membros, aquele que dá voz, num determinado momento, ao movimento grupal. Surge, então, o conceito de protagonista, aquele que emerge do grupo como porta-voz da mudança que se anuncia.

No atual trabalho, cada entrevista em grupo constituiu-se das três etapas: aquecimento, dramatização (ou produção verbal criativa, decorrente de uma abertura espontânea) e comentários. No entanto, como o objetivo era a coleta de dados através de produção verbal, não ocorreram dramatizações propriamente ditas, tendo sido utilizados somente jogos dramáticos para que se conseguisse o aquecimento do grupo.

\section{II - Participantes}

Os participantes do atual estudo foram os agentes escolares e pais de alunos de $3^{\mathrm{a}}$ e $4^{\text {a }}$ séries do ensino fundamental de uma escola pública, localizada num bairro periférico de uma cidade do interior do Estado de São Paulo.

A escola, em 2001, quando se deu início à observação participante, estava funcionando de $3^{\mathrm{a}}$ a $8^{\mathrm{a}}$ séries, passando pelo processo de transição, onde, por ser 
estadual, deveria atender de $5^{\mathrm{a}}$ a $8^{\mathrm{a}}$ e não mais de $1^{\mathrm{a}}$ a $4^{\mathrm{a}}$. Assim, o atual estudo priorizou o ensino fundamental ainda em funcionamento na escola, especialmente porque a relação dos professores com a família, nessa etapa, se mostrou mais significativa.

A seleção dos pais de alunos aconteceu da seguinte maneira: após um período de observação participante e contato com os professores, constatou-se que era muito freqüente o fato desses se referirem a alguns pais como aqueles que não respondem às suas solicitações, que "não davam um jeito nos filhos"(sic). Os professores se sentiam insatisfeitos e esse era um assunto recorrente na sala dos professores, nos horários de intervalo.

Foram realizadas, então, entrevistas estruturadas com os dez professores de $3^{\mathrm{a}} \mathrm{e}$ $4^{a}$ séries com o objetivo de identificar os pais que correspondiam e aqueles que não correspondiam às suas expectativas. O questionário aplicado pode ser observado a seguir, tomando-se como exemplo algumas das respostas da professora da 4 árie A:

1. Em que grau os familiares dos alunos respondem às suas solicitações?

\begin{tabular}{|c|c|c|c|c|}
\hline 1 & 2 & 3 & 4 & 5 \\
\hline Nunca & Quase nunca & Algumas vezes & Quase sempre & Sempre \\
\hline
\end{tabular}

2. Colocar a letra $\mathbf{S}$, quando os pais forem solicitados a comparecer na escola fora das reuniões de pais.

\begin{tabular}{|c|c|c|c|c|c|c|}
\hline \multicolumn{2}{|c|}{ ALUNOS $-4^{\mathrm{a}} \mathrm{A}$} & 1 & 2 & 3 & 4 & 5 \\
\hline & A. 0 . & & & & & $\mathrm{X}$ \\
\hline D. D. B. M. & & & & & & $X$ \\
\hline E. R. S. & & & & & & $\mathrm{X}$ \\
\hline F. H. R. & $\mathbf{S}$ & & & & & $\mathrm{X}$ \\
\hline F.P. G. & $\mathbf{S}$ & & & & $\mathrm{X}$ & \\
\hline G. A. J. S. & & & & & & $\mathrm{X}$ \\
\hline J. M. G. S. & $\mathbf{S}$ & & $X$ & & & \\
\hline
\end{tabular}

Com base nas respostas de todas as professoras, observou-se o seguinte:

- 27 pais eram solicitados a comparecer na escola fora das reuniões de pais, num total de 339 (163 de $3^{\text {a }}$ série e 176 de $4^{\text {a }}$ série), ou seja, 7,96\%;

- 277 pais de alunos respondiam às expectativas das professoras sempre ou quase sempre, ou seja, $\mathbf{8 1}, \mathbf{7 \%}$;

- 36 pais de alunos não respondiam às expectativas das professoras nunca ou quase nunca, ou seja, $\mathbf{1 0 , 6 \%}$; 
- 26 pais de alunos respondiam às expectativas das professoras algumas vezes, ou seja, $\mathbf{7 , 7 \%}$.

Diante deste perfil, buscou-se definir uma amostra levando em conta o fato de que, em pesquisa qualitativa, a preocupação maior é com o aprofundamento e abrangência da compreensão, mais do que com a generalização e a representatividade. Assim, optou-se pelos seguintes critérios, sugeridos por Minayo (1996): a) definir o grupo social mais relevante para as entrevistas, b) não esgotar a amostra enquanto não estiver delineado o quadro empírico da pesquisa, c) o conjunto de informantes deve ser diversificado para possibilitar a apreensão das semelhanças e diferenças, d) deve-se prever uma triangulação, ou seja, utilizar mais de uma abordagem para coleta de dados. (p.102)

Os entrevistados foram selecionados segundo os parâmetros acima, mantendo-se uma uniformidade em termos da série do aluno, pais solicitados e não solicitados fora das reuniões de pais e grau de resposta dos pais às expectativas das professoras (nesse caso foram utilizadas somente as respostas 1 e 2 - significando o não cumprimento das expectativas e solicitações das professoras, e 4 e 5 - significando o cumprimento das expectativas e solicitações das professoras).

Foram realizadas, então, 22 entrevistas semi-estruturadas, nas casas dos pais, sendo que uma delas foi descartada pelo fato do pai ter iniciado a entrevista e a mãe terminado $\left(\mathrm{n}^{\circ} 4\right)$. Os pais entrevistados ${ }^{11}$ podem ser visualizados no quadro a seguir:

\footnotetext{
${ }^{11}$ Os nomes dos pais e dos alunos são fictícios.
} 


\begin{tabular}{|c|c|c|c|c|c|}
\hline $\begin{array}{c}\text { Alunos cujos pais são } \\
\text { solicitados pela } \\
\text { professora }\end{array}$ & $\begin{array}{c}\text { Série do } \\
\text { aluno }\end{array}$ & $\begin{array}{c}\text { Grau de } \\
\text { resposta dos } \\
\text { pais }\end{array}$ & $\begin{array}{c}\text { Alunos cujos pais não } \\
\text { são solicitados pela } \\
\text { professora }\end{array}$ & $\begin{array}{c}\text { Série do } \\
\text { aluno }\end{array}$ & $\begin{array}{c}\text { Grau de } \\
\text { resposta dos } \\
\text { pais }\end{array}$ \\
\hline Aluno: Marcos & $3^{a} A$ & 5 & Aluno: Marcelo & $3^{a} A$ & 5 \\
\hline Mãe: Silvia & & & Mãe: Sandra $\quad$ E. 22 & & \\
\hline Aluna: Lia & $3^{a} \mathrm{C}$ & 2 & Aluna: Denise & $3^{n} B$ & 1 \\
\hline Mãe: Ilda & & & Mãe: Valéria E. 7 & & \\
\hline Aluno: Hélio & $3^{a} \mathrm{C}$ & 5 & Aluna: Mara & $3^{a} B$ & 1 \\
\hline Mãe: Rafaela & & & Mãe: Elza $\quad$ E.10 & & \\
\hline Aluna: Sara & $3^{n} \mathrm{E}$ & 2 & Aluno: Caio & $3^{\mathrm{a} C}$ & 5 \\
\hline Mãe: Inês & & & Mãe: Gisele & & \\
\hline Aluna: Ana & $3^{n} \mathrm{E}$ & 5 & Aluno: José & $3^{a} E$ & 5 \\
\hline Mãe: Cibele $\quad$ E. 15 & & & Mãe: Rose $\quad$ E.9 & & \\
\hline Aluna: Larissa & $4^{2} \mathrm{~A}$ & 2 & Aluno: Daniel & $4^{a} B$ & 5 \\
\hline Avó: Cristina $\quad$ E. 8 & & & Mãe: Carolina $\quad$ E. 14 & & \\
\hline Aluno: João & $4^{a} \mathrm{~A}$ & 5 & Aluna: Jaqueline & $4^{a} \mathrm{~B}$ & 5 \\
\hline Mãe: Luzia & & & Mãe: Shirley $\quad$ E. 3 & & \\
\hline Aluna: Lúcia & $4^{\mathrm{a} C}$ & 5 & Aluna: Paula & $4^{a} B$ & 5 \\
\hline Mãe: Maria & & & Mãe: Mariana $\quad$ E. 18 & & \\
\hline Aluno: Lucas & $4^{\mathrm{a} D}$ & 5 & Aluna: Laura & $4^{\mathrm{a} C}$ & 1 \\
\hline Pai: Mauro & & & Mãe: Jerusa & & \\
\hline Aluno: Wagner & $4^{\mathrm{a}} \mathrm{E}$ & 2 & Aluna: Taís & $4^{a} E$ & 1 \\
\hline Mãe: Fabiana E. 16 & & & Mãe: Roberta E. 12 & & \\
\hline & & & Aluna: Carina & $4^{a} \mathrm{E}$ & 2 \\
\hline & & & Mãe: Rita $\quad$ E.11 & & \\
\hline
\end{tabular}

Quadro 1: Pais entrevistados individualmente (Legenda: E.= Entrevista)

Após as entrevistas individuais, foram realizadas também, duas entrevistas em grupos focais, onde todos os pais entrevistados individualmente foram convidados a participar, mas compareceram somente oito no primeiro encontro e seis no segundo encontro. Os participantes dos grupos podem ser verificados no quadro a seguir: 


\begin{tabular}{|l|l|}
\hline \multicolumn{1}{|c|}{ Primeiro encontro } & \multicolumn{1}{c|}{ Segundo encontro } \\
\hline Rafaela - Entrevista 9 & Rafaela - Entrevista 1 \\
\hline Rose - Entrevista 1 & Rose - Entrevista 9 \\
\hline Gisele - Entrevista 19 & Gisele - Entrevista 19 \\
\hline Mauro - Entrevista 6 & Mauro - Entrevista 6 \\
\hline Valéria - Entrevista 7 & Valéria - Entrevista 7 \\
\hline Cibele - Entrevista 15 & Sandra - Entrevista 22 \\
\hline Carolina - Entrevista 14 & \\
\hline Maria - Entrevista 2 & \\
\hline
\end{tabular}

Quadro 2 - Participantes das entrevistas em grupo focal

Foram realizadas, ainda, entrevistas semi-estruturadas com a diretora e vicediretora, com o objetivo de conhecer um pouco mais a escola.

\section{III - Procedimentos da Pesquisa de Campo}

\section{1 - Estratégias de coleta de dados}

Os passos da investigação foram sendo definidos no confronto com o campo e a coleta de dados aconteceu em três fases, descritas a seguir como momentos da pesquisa:

I - Fase exploratória ou descritiva, realizada por meio de Observação Participante, ou conversas informais com as várias pessoas que participam do cotidiano escolar. Além disso, foram analisados alguns documentos como a proposta pedagógica da escola, regimento e gestão escolar. O objetivo aqui foi conhecer a instituição como um todo, antes de abordar o tema específico, além de identificar os informantes, ou participantes da pesquisa.

II - Fase focalizada, realizada por meio de entrevistas individuais, semi-estruturadas, com os participantes já identificados, pais de alunos de $3^{\mathrm{a}}$ e $4^{\mathrm{a}}$ séries, visando conhecer suas representações sobre a escola e sua participação na vida escolar dos filhos. Por se tratar de um estudo qualitativo, o número de pais entrevistados não foi determinado $a$ priori, sendo o suficiente para permitir uma reincidência das informações, além de 
conter uma certa diversidade, para que as semelhanças e diferenças pudessem ser apreendidas. $\mathrm{O}$ critério, portanto, foi a obtenção de uma compreensão aprofundada e abrangente do grupo social estudado.

III - Fase seletiva, realizada através de entrevistas em grupo focal com os pais entrevistados na etapa anterior, com o objetivo de promover um aprofundamento dos dados já obtidos. Foram realizadas, ainda, entrevistas semi-estruturadas com a diretora e vice-diretora da escola, com o objetivo de conhecer um pouco mais a vida escolar, além de esclarecer aspectos que ficaram pendentes no decorrer da pesquisa.

\section{2 - Descrição da Coleta de Dados}

I- Fase exploratória:

No segundo semestre de 2001 a escola foi contatada e foram combinados os procedimentos da pesquisa com a diretora. A partir daí, iniciou-se a observação participante, que ocorreu no segundo semestre de 2001, e durante quase todo o ano de 2002. Na escola, ela ocorreu em períodos alternados, de uma a duas vezes por semana, com sessões de 2 a 4 horas. Foram observados, então, a entrada e saída de alunos, o recreio, os professores no intervalo, o ambiente físico da escola, o funcionamento da biblioteca, da secretaria, da administração escolar, além de terem sido realizadas conversas informais com as inspetoras, a caseira, a coordenadora, a diretora, os professores, as merendeiras, alunos e pais (amigos da escola). Todas as observações descritas foram registradas em Diário de Campo.

Nessa etapa foram realizadas, ainda, entrevistas estruturadas com as professoras de $3^{\mathrm{a}}$ e $4^{\mathrm{a}}$ séries, para levantamento da amostragem, além de consultas a documentos históricos e oficiais da escola, fotocopiados com a permissão da diretora. Foram analisados documentos tais como: a proposta pedagógica da escola, o regimento escolar, o plano de gestão (1999-2202), com o objetivo de contextualizar e compreender a escola estudada. Foram consultados, também, os arquivos históricos do Município e arquivos da Delegacia Regional de Ensino e Educação, com o objetivo de conhecer a história da cidade e obter alguns dados relativos ao ensino público da região.

Por fim, buscou-se junto à secretaria da escola os endereços dos pais selecionados, para que se desse início às entrevistas individuais. A pesquisadora 
realizou pessoalmente esse levantamento dos endereços, para que nenhuma outra pessoa presente no cotidiano escolar pudesse identificar os participantes da pesquisa.

\section{II- Fase focalizada:}

Foram realizadas as visitas nas residências, quando era feito o convite para a participação no estudo. Apesar da intenção da pesquisadora ser de que essa primeira visita fosse somente para marcar a data da entrevista, a maioria dos pais disse que ela poderia ser feita naquele mesmo momento. Os pais eram, então, esclarecidos sobre os objetivos e implicações da pesquisa e solicitados a assinar o termo de consentimento esclarecido. Nos casos em que o participante era analfabeto, a entrevistadora lia o termo em voz alta, com o gravador ligado e o entrevistado dizia se estava de acordo ou não com a participação na pesquisa. O termo de consentimento esclarecido (Anexo A) foi elaborado segundo as recomendações da Resolução 196/96 do Conselho Nacional de Saúde e demais legislações sobre a ética de pesquisa com seres humanos.

Nota-se que alguns pais selecionados não foram encontrados no endereço dado pela escola, e outros se recusaram a participar da pesquisa.

As entrevistas (vide o roteiro no Anexo B) consistiam em dois blocos, um temático e outro de contextualização e, antes que fossem iniciadas com os sujeitos, foram realizadas duas entrevistas piloto, com o objetivo de testar e adequar o roteiro de entrevista à realidade daquela população. Definiu-se, aí, a seqüência dos temas da entrevista. Ela deveria ser iniciada pelos temas relativos à contextualização familiar, que pareceram provocar, mais do que a parte temática sobre a escola, uma "quebra de gelo", deixando os entrevistados mais à vontade. O Bloco de Contextualização consistia na história da família (como surgiu e local de origem), sua constituição (número de pessoas que vivem na casa, pessoas que trabalham) e escolaridade de seus integrantes. O Bloco Temático consistia em três temas: Professor(a) do meu filho, Escola do meu filho e Escolaridade, que eram apresentados aos pais, um a um, sendo-lhes solicitado que pensassem sobre o tema antes de começar a responder, deixando vir à mente tudo que lembravam. Em seguida começavam a responder e o gravador era ligado.

A observação participante aconteceu também nas visitas domiciliares (enfocando: a estrutura física da casa, atividade em andamento, cuidado com os filhos, relações que aconteciam no momento da entrevista) nas caminhadas pelo bairro, na negociação do uso do Centro Comunitário com o líder comunitário, entre outros. Dessa 
forma, ocorreu durante todo o tempo de contato com o campo que, durante a fase de coleta de dados foi constante (especialmente no primeiro semestre de 2002). Essas observações permitiram o contato com os modos de vida da população estudada, seus costumes, objetivando, assim, a contextualização dos seus relatos.

Como as entrevistas eram realizadas no período da manhã ou da tarde, as mães se encontravam mais em casa do que os pais (foram encontrados somente três pais em casa nesse horário: um deles foi entrevistado, o outro preferiu que a mulher realizasse a entrevista e o último iniciou respondendo às questões, até que a sua mulher chegou e foi respondendo no seu lugar). Assim, dentre as entrevistas válidas para a análise, tem-se 20 mães, 1 avó e 1 pai entrevistado.

O tempo de permanência nas casas foi de 1 a 3 horas, uma vez que os acontecimentos cotidianos, em alguns casos, impediam o fluxo contínuo da entrevista. Além disso, muitos entrevistados se estendiam muito, quando solicitados a falar da própria história. Em algumas casas, a pesquisadora teve que voltar até três vezes para conseguir que a mãe estivesse em condições de ser entrevistada. As entrevistas ocorriam, na maioria das vezes, na sala das casas, tendo ocorrido, também, na calçada, na cozinha e no quintal. De modo geral, os entrevistados mostraram prazer e interesse em falar o que pensavam sobre os assuntos solicitados e alguns faziam questão de servir um cafezinho, um suco, refrigerante ou o que tinham para oferecer. No final das entrevistas, foi comum o convite para que a pesquisadora voltasse a visitá-los numa outra oportunidade.

\section{III- Fase seletiva:}

Os pais entrevistados individualmente foram convidados a participar de uma entrevista em grupo focal, que ocorreria no Centro Comunitário do bairro. Definiu-se um horário onde eles teriam maior possibilidade de comparecer: às quartas feiras, às 19: 15h. O tema investigado foi, ainda, "A escola do(a) filho(a)."

No primeiro encontro compareceram 8 pessoas. Foi realizado um aquecimento inicial, onde se buscou a integração grupal e a flexibilização das questões sociométricas. Uma vez conseguido esse objetivo, o grupo passou à discussão do tema proposto pela pesquisadora. Para finalizar, houve um compartilhamento dos sentimentos vividos durante o processo do grupo e foi combinada a nova data para o próximo encontro, que ocorreria daí a quinze dias (devido ao pedido de uma das integrantes do grupo). 
Já no segundo encontro, houve um aprofundamento dos temas abordados no primeiro. Compareceram 6 pessoas, sendo que uma delas não havia participado do encontro anterior, tendo sido convidada, espontaneamente, por uma das participantes.

A própria pesquisadora foi a coordenadora ${ }^{12}$ das entrevistas em grupo focal e contou com a ajuda de uma auxiliar, que cuidou dos gravadores.

A duração dos grupos foi de aproximadamente duas horas, sendo que os participantes ainda ficavam cerca de uma hora reunidos, conversando e comendo o lanche levado pela entrevistadora. Ficou claro o sentimento de cumplicidade criado, além da emergência de conteúdos ainda não revelados nas entrevistas individuais.

Um outro aspecto importante é que, devido às difíceis condições de segurança do bairro, a pesquisadora buscou e levou a maioria dos participantes até suas casas.

Nessa etapa foram também realizadas entrevistas com a diretora e vice-diretora da escola e o tema de investigação foi "A relação com os pais de alunos". Cada entrevista durou cerca de duas horas, sendo que outros temas relativos à vivência escolar foram trazidos espontaneamente por elas, principalmente após o gravador ser desligado.

\section{IV - Análise dos dados}

Segundo Biasoli-Alves (1998), a análise dos dados deve "buscar uma apreensão de significados nas falas ou em outros comportamentos observados dos sujeitos, interligados ao contexto em que se inserem e delimitados pela abordagem conceitual do pesquisador.(...)” (p. 149) Esse sistema de análise, denominado "Sistema Qualitativo", é caracterizado pela autora da seguinte forma:

(...) pode ser considerado como um processo indutivo de analisar dados descritivos da realidade, tendo como foco a fidelidade ao universo de vida cotidiana dos sujeitos: observados e/ou entrevistados. Sua função seria apreender o caráter multidimensional dos fenômenos em sua manifestação natural, bem como captar os diferentes significados de experiências vividas, auxiliando a compreensão do indivíduo no seu contexto." (BIASOLI-ALVES, 1998, p. 149-150)

\footnotetext{
${ }^{12} \mathrm{Na}$ abordagem psicodramática o coordenador do grupo é chamado de diretor, mas como se buscou seguir as prescrições de Vaughn, Schumm e Sinagub (1996) para as entrevistas em grupo focal, o termo utilizado foi "coordenador" do grupo.
} 
A seguir pode ser verificado mais detalhadamente o procedimento de análise das entrevistas individuais e em grupos focais:

\section{1 - Entrevistas Individuais}

As entrevistas individuais foram analisadas por meio de uma análise de conteúdo, segundo os moldes propostos por Bardin (1977), onde os segmentos de relatos são separados e classificados de acordo com seu conteúdo, depois de repetidas leituras das entrevistas transcritas na íntegra.

Em seguida, buscou-se obter indicadores que permitissem a inferência do significado latente dos enunciados e dos fatores que determinaram as condições de produção das mensagens.

Foram estabelecidas, assim, além das categorias analíticas, construídas com base numa revisão bibliográfica sobre o tema, as categorias empíricas, ou seja, aquelas construídas a partir de várias releituras das entrevistas, abarcando os aspectos que foram trazidos pelos entrevistados sem um estímulo específico da pesquisadora. Mesmo no caso das categorias analíticas, apenas o "bloco temático", ou seja, a reunião de várias categorias num mesmo agrupamento, é que se derivou da revisão bibliográfica, na forma de temas propostos pelo roteiro de entrevista. Já as categorias propriamente ditas, que compunham estes blocos, foram levantadas empiricamente a partir das várias releituras do material obtido.

Foram constituídos, então, os vários agrupamentos de comunicações para, em seguida, ser realizado seu enxugamento, mantendo os temas mais relevantes. Por fim, buscou-se estabelecer relações entre as várias categorias, situando-as no contexto de produção do relato e no contexto sócio-histórico mais amplo, apreendido por meio da observação participante, entrevistas informais, análise documental, etc.

Vale notar que dentro da proposta de análise hermenêutica-dialética, desenvolvida por Minayo (1996), a interpretação deve superar a dicotomia entre objetividade versus subjetividade, exterioridade versus interioridade, análise e síntese, e revelar que o produto da pesquisa é um momento da praxis do pesquisador. 


\section{2 - Entrevistas em grupo focal}

As entrevistas em grupo focal foram analisadas de acordo com a análise sociométrica proposta por Milan (1976), dentro do referencial teórico do Psicodrama.

Marilena Chauí, no prefácio da obra de Milan (1976), aponta que:

O grupo é uma modalidade de coexistência onde o indivíduo se insere e que se define pela existência de um projeto comum onde se exprime o desejo de cada um e o de todos, na forma de uma intersubjetividade em ato, constituída pela busca do reconhecimento recíproco. $\mathrm{O}$ grupo é uma estrutura. Isto significa que é uma totalidade provida de sentido, um sistema onde as unidades se definem por suas posições e oposições referenciadas, isto é, por suas identidades irredutíveis à mera soma dos indivíduos reunidos. (CHAUÍ, 1976, in: Milan, p.124, 125)

Nessa perspectiva, o grupo é uma estrutura intersubjetiva onde o desejo dos indivíduos e o projeto grupal se articulam de maneira harmoniosa ou contraditória, o que configura as unidades sociométricas que o compõem. Assim, a análise das sessões de grupo visou identificar os projetos do grupo e se os indivíduos se colocavam a favor ou contra o movimento grupal que estava ocorrendo no momento. A essas unidades deu-se o nome de momentos do grupo.

A análise das entrevistas em grupo focal seguiu os seguintes passos:

$\left.1^{\circ}\right)$ Foram delineadas as etapas da sessão: Aquecimento, desenvolvimento e comentários.

$2^{\circ}$ ) Dentro de cada uma delas buscou-se identificar os projetos grupais que ocorreram, identificando seus momentos.

$3^{\circ}$ ) Em seguida buscou-se identificar dentro de cada projeto, as unidades sociométricas que se articulavam entre si, de forma harmônica ou contraditória.

$4^{\circ}$ ) Por fim, foi realizada uma análise de conteúdo, onde se levantou os temas discutidos em cada momento. 


\title{
CAPÍTULO III - RESULTADOS
}

\author{
"Agora, de onde falo, ao pé do fogo, a ti que se dá \\ atenção de me ouvir, lembro-me de que não tinha idéia \\ de como esses acontecimentos sufocavam meu espirito \\ sem nome, de como tais sentimentos escondiam minha \\ ave-alma. Só. Andava por aquele chão sem estar. \\ Então, aos poucos, ia reencontrar minha música, \\ minha dança, meu vôo" \\ kaká Werá Jecupé, Todas as vezes que dissemos \\ adeus, p. 39, 2002).
}

$\mathrm{O}$ atual capítulo foi subdividido em três partes, sendo a primeira a apresentação dos resultados relativos ao contexto da pesquisa. A segunda traz os resultados temáticos provenientes das entrevistas individuais e a terceira seção trata dos resultados obtidos com as entrevistas em grupos focais.

\section{I- O contexto da Pesquisa}

De acordo com o referencial teórico utilizado no atual estudo, é de suma importância que sejam delineados os contextos nos quais acontece a coleta de dados. Assim, deve-se conhecer a escola, o local onde está inserida, ou seja, o bairro e o município, além das famílias dos pais entrevistados, sua configuração e história. Seguese, portanto, o atual capítulo, com o objetivo de traçar um panorama geral, onde os resultados temáticos do estudo possam ser apoiados e contextualizados.

\section{1 - O município}

A cidade, situada no interior do Estado de São Paulo e hoje com cerca de 300.000 habitantes, surgiu a partir "da rota do Sal", quando os mineiros dos vales do Rio Grande, do Sapucaí, do Pardo e do alto São Francisco vieram povoando as fronteiras recém-estabelecidas de São Paulo. Quando o ciclo do ouro foi se esgotando nos grandes centros mineradores, a população em excesso desses locais começou a refluir para zonas ainda desocupadas e com terra fértil para exercer outras atividades. 
Surgiu, então, a freguesia, constituída por fazendas auto-suficientes, que produziam para a sua subsistência, sendo mínima a importância dos estabelecimentos comerciais.

Em 1819, o arraial contava com 132 pessoas, sendo 59 componentes das famílias cabeças de fogo, que eram famílias patriarcais; 16 agregados; 14 fâmulos (criados) e 43 escravos. As profissões apresentavam as seguintes quantidades: quatro padres, quatro carpinteiros, dois jornaleiros, um ferreiro, um taberneiro e alfaiate e um negociante. Tinha-se o registro, ainda, de dois doentes e três meretrizes. Assim, a população permanente do arraial era minoritária em proporção ao restante da freguesia, pois o poder, a riqueza e o status estavam nas mãos dos pecuaristas e agricultores.

Por volta de 1860 , a cidade já era bem povoada e o cultivo do café abria-lhe novas perspectivas. Além disso, a chegada da companhia ferroviária deu um grande impulso ao seu desenvolvimento, quando houve os princípios de urbanização e modernização. As atividades produtivas continuavam concentradas no campo e a economia voltada para a produção e exportação do café.

A partir de 1950, a cidade passou por um acelerado processo de industrialização, cujo principal produto, o calçado, foi destinado ao mercado externo, prioritariamente. Nessa fase, a cidade recebeu um grande contingente de migrantes mineiros que, expulsos do campo, transformaram-se em operários fabris num curto espaço de tempo.

Durante o período de 1960 a 1980, obedecendo aos objetivos gerais dos governos militares, exportar produtos como forma de obter saldo positivo na balança comercial, houve um grande desenvolvimento industrial, gerando também transformações paisagísticas e urbanísticas. Ocorreu, nessa época, um grande êxodo rural, sendo a maior parte dos trabalhadores que chegavam à cidade, originários de pequenas localidades próximas ao estado de São Paulo, vindos do sul de Minas Gerais (fluxo que permaneceu constante durante todo o período). De acordo com o censo do IBGE (2000), a cidade possui, hoje, uma concentração da população na área urbana de $97 \%$.

Com relação à educação, segundo dados obtidos na Delegacia de Ensino, a Rede estadual de ensino na cidade conta com 47 escolas e ainda duas escolas rurais, atendendo um total de 48.983 alunos. Já a rede municipal atende cerca de 6800 crianças em Educação Infantil e 8000 crianças no Ciclo I do Ensino fundamental. 


\section{2 - O Bairro}

A escola estudada situa-se no Jardim Esmeralda, na periferia da cidade e atende, primordialmente, alunos dos bairros Jardim Esmeralda e Jardim Pintangueiras, atendendo também o Jardim Bela Vista e chácaras vizinhas (os nomes dos bairros são fictícios). Segundo os dados contidos no Plano de Gestão (documento confidencial cedido pela escola):

[...] trata-se de uma comunidade onde a maioria das famílias é de nível sócio-econômico baixo[...]. São, em sua maioria, trabalhadores de fábricas, bancas de pespontos, pedreiros e trabalhadores braçais, morando em casas próprias, populares ou semi-acabadas. A comunidade é servida totalmente por rede de esgoto, água potável, coleta de lixo e energia elétrica. Possui também linhas de ônibus que facilitam o transporte dos moradores. Quanto ao lazer, o bairro possui apenas uma praça pública, não existem cinemas, teatros, etc. Na parte de assistência médica, os moradores são atendidos pelo UBS (Unidade Básica de Saúde) localizado num bairro vizinho e pelos médicos conveniados às indústrias nas quais trabalham. Quanto à religião, a maioria da comunidade é católica[...]. Existem ainda adeptos às Igrejas Evangélicas, Entidades espíritas, etc.

Observou-se, no entanto, uma diferença marcante entre os bairros Jardim Esmeralda e Jardim Pitangueiras. O primeiro possui muitas casas grandes e algumas mais simples, mas sempre acabadas e com fachadas arrumadas. É um bairro residencial, arborizado e plano, com escolas e praças, sendo predominantemente de classe média. No final de tarde é comum ver crianças brincando na rua, sem os adultos.

Já a maior parte do Jardim Pitangueiras é constituída por casas populares, semiacabadas, enfileiradas em duas colinas que abrem um grotão no meio. (Os moradores chamam esse lugar de "buracão"). É um bairro com algum comércio, bares e oficinas, sendo a maioria da sua população de nível sócio-econômico baixo. É comum nos finais de tarde a população sentar-se às portas das casas, mulheres costurando sapatos, grupos de homens fazendo transporte de materiais pesados a pé, fazendo mudanças, consertando carros, ou conversando nas esquinas. As crianças também correm pelas ruas e é comum ver grupos de adolescentes sentados às esquinas. Os depoimentos dos pais entrevistados mostram que o Jardim Pitangueiras é um bairro bom, que está crescendo, mas que tem "problemas de drogas" (sic).

"Aqui era um buracão. Aqui era cheio de árvore. O bairro, aqui. Aqui tinham poucas casa(...) Ai eles pegô e foi fazendo terraplanagem, né? E fazeno... As casinha. Foi 
fazeno os, as escadinha. E o, e virô escadinha, né? Porque ó... É morro acima." (Elza)

"Pra ser sincero é um bairro até bom para se morar.(..) Tranqüilo. Algum dia tem lá suas pendências, tem umas coisas aí negócios de droga.(...) E é esse tipo de coisa aí que atrapalha." (Sr. Mauro)

Os relatos da Rose e da D. Célia também trazem a história da construção do bairro, as dificuldades vividas e a participação da comunidade para que se conseguisse "melhorias":

"Eu fiquei aqui dois ano sem água e treis ano sem força. A gente vivia aqui à lamparina e lampião. Nossa, era terrivel.(...) A gente fazia reuniões nas casas: vamo debater o que tá precisando no bairro, o bairro tá precisando de água, de asfalto, de força. Isso aqui foi uma luta pra gente conseguir." (Rose)

"Toda veiz que a rádio tá aqui embaixo nóis vamo lá. Nóis reclama, nóis pedimo. Mais ninguém faiz nada. Esqueceram daqui, porque aqui já é morro, cê sabe, eles não faiz. Então minha filha, Graças a Deus que pelo menos a escola no bairro nóis conseguiu." (D. Célia)

Com relação ao Jardim Esmeralda, os relatos enfatizaram a união entre os moradores e o clima tranqüilo do bairro:

"Faiz três anos que eu tô aqui no bairro(...). O bairro aqui é bom, eu gosto.(...) É muito sossegado, bem tranqüilo.” (Rafaela)

"Roubo tem. Desde que fez o bairro Pitangueiras, tem. E agora eu ouço falar assim, negócio de droga aqui. É o seguinte, tem pouco, não tem tanto igual em outros lugares, sabe.(...) Quem mora aqui é dificil de mudá daqui ." (Luzia)

Outros entrevistados contaram a história do bairro, já que são moradores antigos:

“Aqui faz 16 anos que eu moro.(...) Quando nóis mudemo pra cá, pegava água nos tambor, nos caminhão de pipa, né? (...) Dava banho nas criança de tambor, né? Ensaboava e enfiava eles lá.(...) Aqui num tinha nem luz. Num tinha, não. Num tinha rede de esgoto, num tinha água, num tinha nada. Tinha só essas casinha. Aqui era só árvore.(...)É, e aqui todo mundo foi amigo, assim, um do outro, sabe?(...) Aqui era tudo unido, sabe? Aqui ninguém era, assim, quando um não tinha o outro servia o outro, e é assim até hoje.(...)Aqui é um lugar quieto, calmo, aqui não tem briga. Não tem ladrão." (Dona Rita)

"O resto aqui tudo era mato. O bairro quase que num tinha nada. Eu murria de medo de morá aqui.(...) Aqui num tinha rede telefônica.(...) Num tinha uma casa, num tinha um vizinho.(...)Ai, ééé, depois que foi construindo aos poucos.(...) Num, num tinha ônibus na minha época." (Gisele) 


\section{3- A Escola}

\section{1- Espaço físico}

A escola funciona com oito salas de aula, biblioteca, sala de professores, secretaria, sala de direção conjugada com vice-direção, almoxarifado, cozinha, quadra de esportes, pátio, dois banheiros para professores (um masculino e um feminino), um banheiro masculino para os alunos com dois vasos sanitários, um banheiro feminino para as alunas com quatro vasos sanitários, casa de zeladoria, jardim e estacionamento.

O prédio da escola é simples, mas muito bem cuidado. Pintado de amarelo, com chão de cimento encerado, brilhante e sem sujeira alguma. Na entrada tem um jardim com flores e árvores. A secretaria fica nesse local, estando sempre limpa e arrumada, com vasos de flores sobre as mesas e adesivos enfeitando os armários.

A escola é murada, havendo uma entrada principal para pais e funcionários na frente e uma entrada na rua de baixo para os alunos. O portão de entrada dos alunos fica trancado durante o período de aula, sendo aberto somente para entrada e saída de alunos. O portão da entrada principal fica aberto, dando acesso à secretaria, mas em seguida há um outro portão, sempre trancado, que impede a entrada direta nos outros recintos escolares.

O pátio é coberto, pequeno, contendo bebedouros presos nas paredes, duas mesas retangulares e dois bancos. A cozinha é grande, arrumada e fica aberta ao pátio. A merenda é considerada muito boa e os professores também costumam se servir na hora do intervalo.

$\mathrm{Na}$ sala da direção são guardados alguns equipamentos mais caros, como TV, vídeo e aparelho de som. A escola não possui computadores, além do único utilizado na secretaria. A sala dos professores possui vários quadros nas paredes: de avisos, mensagens religiosas, entre outros, além de um armário (trancado) de materiais e um bebedouro. No intervalo é servido café na mesa dos professores.

A sala da coordenadora funciona junto com a biblioteca (com cerca de 1000 livros), sendo muito comum observá-la cheia de alunos, que formam filas para pegar livros. Os alunos maiores auxiliam os menores e também a coordenadora, que é a pessoa responsável pelo funcionamento da biblioteca e por consertar livros estragados. 
Os banheiros normalmente são limpos, assim como todo o espaço da escola, interno e externo, não havendo rabiscos ou pixações.

\section{2- Clientela}

A escola conta com cerca de 1100 alunos e funciona em três turnos, manhã, tarde e noite. Ministra o ensino fundamental, de $3^{\mathrm{a}}$ a $8^{\mathrm{a}}$ séries em regime da progressão continuada, "com a finalidade de garantir a todos, o direito público de acesso, permanência e sucesso no ensino fundamental" (Proposta Pedagógica, documento confidencial cedido pela escola). Ela oferece, também, um curso supletivo no período noturno, o qual muitos pais de alunos relataram estar cursando.

\section{3 - História}

De acordo com as publicações do Diário Oficial, a escola foi criada em 1989 como Unidade Escolar (agrupada), funcionando com seis classes de $1^{\mathrm{a}}$ a $4^{\mathrm{a}}$ séries. Em 1990, recebeu seu nome e em 1992 foi transformada em EEPG. Em 1997, ela passou a atender alunos de $1^{\text {a }}$ a $8^{\text {a }}$ séries, integrando a Rede Pública Estadual, sob Jurisdição da Secretaria da Educação.

Segundo um artigo publicado em um jornal do município, no dia 14 de março de 1993, a prefeitura construiu duas novas salas de aula na escola para atender melhor a clientela estudantil do bairro, no início do ano letivo. Isso foi conseqüência da inauguração das casas populares do Jardim Pitangueiras, cujos moradores não teriam onde matricular seus filhos. $\mathrm{O}$ artigo aponta, ainda, que a escola contava com apenas duas salas de aula, funcionando em quatro períodos, para atender seus 500 alunos matriculados. A prefeitura só assumiu as obras em caráter emergencial, uma vez que a ampliação deveria contar com recursos estatais.

De acordo com relatos orais de integrantes da escola, mais especificamente da diretora, e de pais de alunos, observa-se que o crescimento dessa escola aconteceu a partir de movimentos reivindicativos, onde escola e comunidade fizeram alianças eficazes. Eles conseguiram benefícios através de vias alternativas, mobilizando políticos locais e radialistas. Dessa forma a escola vem crescendo...

Nesse movimento, a figura da diretora se destaca como protagonista. No relato que se segue, ela deixa claro seu posicionamento de aliança com a comunidade, 
confrontando seus mandantes, que propõem o apoio da população para $o$ autofinanciamento da escola. Ela mostrou defender tanto os pais quanto os professores dessa sobrecarga, se mantendo na busca de outras alternativas:

"Eu comecei com a secretaria, pedindo o chapéu para todo mundo e tal e tal(...) Eu tentei de tudo, os políticos aqui da cidade, os vereadores, o prefeito.(...) Falavam: reuna os pais, faça promoção. Imagina, como fazer promoção para ampliar uma escola que não tem secretaria, que não tem uma biblioteca, que não tem uma diretoria, que não tem sala de professor direito, né. Eu vou ter que fazer festa como? Fazer mutirão? Porque a comunidade começa, mas é aquela coisa, durante a semana coitados, eles também têm que ganhar o pão deles, o pão de cada dia. E outra, professor tem horário, tem família. Pra comunidade vir teria que ser sábado e domingo. E os nossos descansos, como é que ia ficar? Então tudo isso era muito complicado, precisava receber o apoio do Estado. " (Diretora)

Em vários momentos, essa escola resistiu ao que lhe era imposto e fez sua aliança com a comunidade em outra direção, através de movimentos reivindicativos. Vale ressaltar que foram vários os relatos dos pais entrevistados sobre esses momentos, sempre dando uma conotação positiva a eles, como pode ser exemplificado a seguir:

"A escola era assim, bem simplezinha, né?(...)Era pouca classe, não tinha diretoria, não tinha sala dos professor, que se reúne, ali, não tinha. Não tinha o pavilhão, né? Que é o pátio, né?(...) Aí depois, com as campanha que elas foi fazendo, né? Com os pais, né? (...) Foi aumentando a escola, aumentando, e sempre as minhas criança ali, né? (...)E, foi erguido com muito sacrifício. A diretora lutou muito, e luta até hoje, né? Pra mantê do jeito que ela é." (Dona Rita)

"Até a escola mesmo era piquinininha. Só tinha uma salinha lá. Tinha três periodos de aula..(...) Agora nós já tamo tentando colocar de $1^{\circ}$ a $3^{\circ}$ colegial. Então tá uma batalha. Na segunda-feira nós vamo conversar com o deputado. Vai um grupo de pai e mãe pra ver se a gente consegue. A cobertura da quadra acho que nós já conseguimo. Agora falta as salas de aula." (Gisele)

Um exemplo muito relatado foi o que ocorreu na escola quando houve a municipalização do ensino. Por ser estatal, a escola deveria ficar com clientela de $5^{\mathrm{a}}$ a $8^{\mathrm{a}}$ séries. Como a população não tinha outra no bairro que servisse o Ciclo I, de $1^{\mathrm{a}}$ a $4^{\mathrm{a}}$ séries, os pais iniciaram um movimento para que os filhos ficassem nessa escola. A comunidade contou com o apoio de um deputado, que conseguiu, por meios políticos, que a transição fosse gradual. Enquanto isso, eles teriam como buscar soluções para o problema. Em 2001 (quando esse estudo foi iniciado) a escola estava atendendo de $3^{\mathrm{a}}$ a $8^{\mathrm{a}}$ séries, diminuindo uma classe por ano, até chegar a ficar somente com as séries de $5^{\mathrm{a}}$ 
a $8^{\mathrm{a}}$. A questão foi solucionada no início de 2002, com a inauguração de uma escola municipal no bairro, de $1^{\mathrm{a}}$ a $4^{\mathrm{a}}$ séries. Enquanto isso, as crianças de $1^{\mathrm{a}}$ e $2^{\mathrm{a}}$ séries estudaram numa escola particular do bairro que se solidarizou com o movimento e cedeu duas classes aos alunos da escola pública. A população participou desse movimento, como pode ser observado nos relatos da diretora e de algumas mães:

"Os meninos saíam daqui e iam estudar no C. P.(...) Olha a distância, o centro fica a cerca de 5 quilômetros. Então eu tinha muita pena dos meninos e comecei, né, a caminhada. Fui atrás do prefeito, fui atrás..., sabe fui... (...) (...) Até que eu tentei uma aproximação com um deputado e ele foi assim, se sensibilizou." (Diretora)

"Porque a gente não queria os menino longe de casa.(...) É, aí nós fizemos reunião na casa de alguns pais aqui, fizemo abaixo - assinado e foi lá no prefeito, que é um cara de pau. (...)Até que o R. (deputado) deu uma força muito grande pra nós e aí conseguiu." (Maria)

"Ai elas chamaro nóis e explicou que lá não ia poder ficar mais a $1^{a}$ série.(...) Ai resolveu que a $1^{a}$ série foi pro $M$. (escola particular do bairro). Quando eles tirou a $1^{a}$ série, né, ai os menino estudou a $1^{a}$ e a $2^{a}$ no M.." (Valéria)

"Era os pais dos aluno pedindo: 'nóis vamo fazê um abaixo-assinado, vai pra prefeitura pra eles fazê uma escola pra nóis, que precisa. Nóis num temo dinheiro pra pagar ônibus pra esses menino estudá fora.'(...) Portanto a escola tá lá, conseguiu, tá lá." (D. Célia)

Observa-se, a partir desses relatos, que a escola foi crescendo e ampliando seus recursos, num confronto permanente entre o Estado e os agentes escolares. Em momentos importantes, comunidade e escola se uniram, formando uma resistência ao que era imposto, buscando soluções aos problemas que surgiam no cotidiano escolar.

\section{4- Projetos em andamento}

Estão em andamento na escola vinte projetos, que são atividades relacionadas com objetivos educacionais, visando suprir algumas dificuldades. Alguns deles serão relatados a seguir:

- A escola possui animais (dois gatos e um cachorro), com o objetivo de colaborar com projetos que incluem o trabalho com valores do tipo amor e respeito à natureza (temas transversais), além de não deixar proliferar pombos e ratos na escola (Diretora). 
- Alguns professores do bairro dão aulas de reforço voluntariamente na escola. Como não há espaço físico suficiente, colocam mesas no estacionamento, debaixo das árvores.

- São oferecidas aulas de música e coral na escola, ministradas voluntariamente por uma professora da cidade.

- A escola tem convênio com uma escola de inglês, sendo que 78 crianças estão estudando por um preço simbólico, e também com uma escola particular do bairro, onde os alunos aprendem informática e robótica.

A escola conta com um número insuficiente de funcionários, segundo relatos da diretora, vice-diretora e coordenadora pedagógica. Diante desse cenário, obtém ajuda de mães de alunos, que atuam como inspetoras de alunos, o que é fruto da implantação do projeto "Amigos da escola". A campanha com esse nome foi realizada por uma grande rede televisiva brasileira, a fim de incentivar a população a fazer trabalhos voluntários nas escolas públicas. Sem dúvida, essa é mais uma ação no sentido do autofinanciamento da escola, sobre a qual já se observam inúmeras críticas na literatura (De Rossi, 2001).

No entanto, nessa escola ele parece estar funcionando bem, sendo os relatos das mães muito positivos quanto à sua atuação. Esse fato talvez se explique pelo posicionamento explícito da diretora contra o trabalho dos pais na escola, quando este significa uma sobrecarga. As mães entrevistadas e atuantes mostraram ter tempo e desejo de estar na escola. O que deve ser evitado aqui é a comparação com outros pais. Se a escola enxerga essa atuação como compulsória, esse padrão de funcionamento é imposto de forma genérica aos pais da escola pública, sendo mais um motivo para discriminação.

\section{5- Desempenho pedagógico}

Durante a fase de observação participante foi colocada uma faixa na frente da escola, parabenizando-a pelo $5^{\circ}$ lugar entre as escolas da cidade, na prova do SARESP, que é a avaliação pedagógica do Estado (para verificar a eficiência das escolas públicas). A direção se mostrou muito contente com esse resultado, já que a escola é pequena, tendo competido com outras, tradicionais e renomadas. 


\section{6- Os rituais institucionais}

O horário do recreio é relativamente calmo na escola, feito em dois turnos, saindo cinco classes de cada vez. Os alunos logo se enfileiram na janela da cozinha para ganharem a merenda. Eles comem em pé ou se sentam no chão, pois não há mesas e bancos suficientes.

As crianças ficam sentadas em pequenos grupos, outras caminham pela escola e uma ou outra corre (o que não é permitido). As mães, amigas da escola, estão sempre presentes, no mínimo duas ou três. Além disso, nesse horário algumas mães vêm até a escola para trazer lanche aos seus filhos. Portanto, nem todas as crianças comem a merenda escolar.

No final do recreio, as crianças fazem fila no pátio e cantam uma música religiosa. As mães e professoras ficam na frente das filas e cantam e dançam junto com as crianças. Os alunos de quarta série ficam mais parados e não participam muito da música, já os de terceira série cantam alto e até sambam nesse momento. Na hora de entrar para as classes, os alunos saem, classe por classe, da direita para a esquerda, em filas super organizadas e "disciplinadas".

Quanto à saída dos alunos, enquanto estão dentro da escola, eles saem organizadamente, em filas, classe por classe, parando no meio do pátio, com a supervisão de mães de alunos (uma ou duas) e da inspetora. Sai então da escola, uma fila de cada vez, até chegar à rua. Poucas mães aguardam os filhos a pé e alguns pais esperam de carro. A maioria dos alunos vai embora a pé, andando pelo meio da rua em bandos, descendo em direção ao bairro mais pobre.

A maioria dos alunos usa a camiseta de uniforme, havendo sempre poucas exceções com camisetas de outras cores.

Durante o tempo de observação aconteceram algumas situações de conflito explícito na escola. Em uma delas, a servente tentava impedir que dois alunos fugissem do reforço aos berros. Numa outra situação, a vice-diretora gritava com quatro alunos que correram na hora do recreio.

Quando a diretora intervinha era sempre no sentido de esclarecer a situação, chamando a professora para ver o que havia ocorrido. Talvez essa seja uma postura de amenizar situações, o que é chamado por ela mesma de jogo de cintura, atitude que ela busca explicitamente ao exercer seu cargo. 


\section{7- Os agentes escolares}

\subsection{1- Os professores}

Nos contatos iniciais, os professores falavam muito pouco sobre o funcionamento da escola, e quando o faziam, era de maneira elogiosa, apontando que ela não tinha problemas graves, sendo boa e tendo uma direção firme.

No entanto, apesar do cotidiano escolar ser aparentemente tranqüilo e com poucos conflitos, estes existiam e alguns participantes da escola acabaram por denunciálos. Alguns relatos trouxeram informações que podem ser consideradas "segredos" do funcionamento institucional.

Uma das pessoas que apontou essa questão foi uma professora que não é efetiva do Estado e dá poucas aulas na escola. Ela relatou uma situação em que um aluno havia levado drogas para a escola e estava oferecendo para outros alunos. Depois que ela relatou isso à pesquisadora, disse que talvez não devesse ter contado porque as coisas ruins não deveriam ser faladas, que se deveria tomar cuidado com o que era falado naquele ambiente. Esse fato foi revelador porque ajudou na compreensão da instituição. A escola realmente parecia perfeita à primeira vista e essa parecia ser a política de seu funcionamento: enfatizar as qualidades e negar as dificuldades.

Nos intervalos entre as aulas, os professores conversavam muito sobre as famílias. Além das críticas estereotipadas aos pais, eles se mostraram, também, impotentes diante de algumas situações familiares. Uma das professoras se queixou sobre sua dificuldade frente à situação de uma aluna: a mãe estava presa e o pai tentava sempre estuprá-la. "Não sei se dou comida ou dinheiro para ela, ou se faço uma visita na casa dela, não sei o que fazer." (sic) Outras professoras falaram, também, que havia muitos pais presos por problemas com drogas e uma delas contou que o pai de uma aluna matou a mãe e se suicidou.

Um outro aspecto muito comentado na sala dos professores foi a ausência, no ambiente escolar, dos pais que "mais precisam". "Participam das reuniões só os pais dos bons alunos, mas também só querem saber de nota" (sic). Elas reclamaram, ainda, que no dia dos pais na escola apareceram somente 30 pais. Falaram também das mães que comparecem à escola quando são chamadas e só choram, acabando por não resolver o problema do filho. Uma das professoras disse que já desistiu de tentar contatar os pais porque as mães não respondem seus bilhetes. 
Outra professora disse, ainda, que a escola tem muitas crianças de famílias evangélicas, o que é visto por ela como um problema. A religião não permite o trabalho com alguns temas, por exemplo, o carnaval. Nessa época, quando o tema é explorado pela escola, as mães não deixam os filhos fazerem algumas das tarefas e atividades (sic).

Um outro aspecto levantado na sala dos professores, que pareceu ter a concordância da maioria é que os pais não conhecem o sistema de ensino e não se interessam em conhecê-lo, fazendo somente críticas à escola. Uma das professoras disse que a escola está mais preocupada com as crianças do que os pais. "Eles entregam toda a função para nós. Com a progressão continuada eles se desinteressaram mais ainda. Eles não se sentem atraídos pela escola" (sic).

Alguns professores reclamaram, também, que não há um horário de estudo em casa, não havendo um acompanhamento escolar dos pais. "Nem a mãe do melhor aluno conhece o conteúdo passado na escola. Ela não sabe o que ele estuda não"(sic).

\subsection{2- A coordenadora pedagógica}

A coordenadora ficou na escola só um ano, saindo no início de 2002. No entanto, os contatos com ela foram importantes, tendo revelado algumas das oposições presentes na instituição.

Sua primeira crítica foi em relação aos professores, tendo sido apontada sua dificuldade em fazer com que aderissem aos projetos pedagógicos e às inovações. Ela disse que tem vergonha de pertencer à classe dos professores, que a maioria não se compromete com o trabalho e ainda diz que ganha mal. Ela apontou que são oferecidos cursos excelentes pelo Estado, mas que os professores não comparecem. "E quando vão, eles ficam conversando, não prestam atenção e ainda atrapalham. É vergonhoso" (sic).

Uma professora que estava perto, nesse momento, se defendeu dizendo que é o estresse que faz isso com os professores. A coordenadora colocou, ainda, que os professores são fracos, desinteressados e que os alunos da escola pública realmente ainda não têm condições de concorrer no vestibular para as universidades públicas.

O segundo nível de conflito, relatado por ela, foi em relação à direção da escola, que a princípio parecia também muito democrática. O seu outro lado, apontado no relato da coordenadora, é que a direção exige muito trabalho, cobrando muito além das horas previstas dos professores e da própria coordenadora. Ela colocou, ainda, que na escola 
não se tem conversa, que a direção decide tudo sem ouvir a coletividade. "Eu monto os grupos de reforço, mas ela (diretora) quer no reforço os alunos que ela gosta. Aqueles desinteressados, mais difíceis, ela quer que eu deixe de fora. Mas depois como eu justifico que o aluno foi reprovado e nem passou pelo reforço? E normalmente são aqueles pretinhos, negrinhos, pobres, tudo de pior. Existe aí um problema social, mas a diretora quer decidir tudo. Para escolher a professora de reforço, colocou a sobrinha dela, sendo que ela não dá pra isso, os alunos não aprenderam com ela. Mas a gente não pode falar nada, é sobrinha dela. A outra coordenadora saiu daqui por isso" (sic).

Quanto à relação com os pais, sua posição é a seguinte: “A escola está, de maneira errônea, delegando a eles a função de ensinar, uma vez que eles não têm tempo para isso. A ajuda que os pais devem dar à escola é no recreio e nas festas" (sic). Ela ainda apontou que um dos problemas que a escola enfrenta com os pais é o protecionismo com os filhos "Eles estão sempre protegendo o filho(...). Existe uma falta de limites das crianças porque os pais não conseguem educar" (sic). Por fim, ela colocou que muitos pais não valorizam o estudo e só atrapalham o filho, justificando essa afirmação pelo fato desses alunos não estarem comparecendo ao reforço escolar.

No período seguinte à coleta de dados, mas que a pesquisadora ainda manteve contato com a escola, observou-se a saída dessa coordenadora e a entrada de uma outra, que também não ficou. A escola ainda funcionou um bom tempo sem esse profissional. Diante disso, as seguintes questões são colocadas: Será que o lugar do coordenador pedagógico é bode expiatório nesse modus operandi institucional? Que função ele ocupa nessa estrutura?

Essas questões apontam alguns dos conflitos possivelmente existentes na escola, mas que precisariam ser mais bem investigados. Pode-se dizer que fazem parte daquilo que a instituição esconde daqueles que lhe são estranhos. O pouco que a pesquisadora pôde captar, foi devido ao tempo de convivência, na medida em que se tornava mais próxima dessa realidade. Assim, acabou sendo, em alguns momentos, um ponto de desabafo às pessoas que estavam sofrendo mais com o funcionamento institucional.

\subsection{3- A diretora}

A diretora se mostrou muito próxima à comunidade, tendo sido observados vários momentos em que ela se dedicava a questões de pais de alunos, fazendo longas reuniões. Houve uma situação em que ela se atrasou duas horas no compromisso 
marcado com a pesquisadora, por estar ajudando um pai a resolver problemas familiares.

Além disso, a pesquisadora participou de uma reunião em que ela convidou os pais a aderirem a um abaixo assinado que estava sendo realizado para que um deputado interviesse a favor da escola. Ela relatou a luta para que se conseguisse cobrir a quadra de esportes e ressaltou a necessidade de se ter uma postura gentil e educada para que se conseguissem as melhorias para a escola. $\mathrm{O}$ resultado dessa reunião foi que os pais concordaram quase unanimemente e se dispuseram a participar do abaixo assinado.

Ela própria afirma a prioridade que dá a esse contato com os pais:

"Eu dou assim uma importância muito grande em estar atendendo bem os pais, sabe, de ter assim uma abertura, porque os pais já ficam assim receosos, acha que o professor, que a escola está muito além né. Então eu faço o pai sentir que não somos, que a gente precisa da participação deles para que as crianças gostem da escola. Então eu perco assim, eu deixo a parte..., às vezes fico até prejudicada na questão de entrega de documento, às vezes atrasa um dia. Porque quando um pai me procura, eu dou assim, atenção.(...)Então, primeiro eu acho muito importante porque o aluno ele fica, ele se sente mais estimulado, ele gosta mais da escola, ele se interessa mais.(...) Eu acho que os pais também, é bom que eles são testemunha do trabalho que a gente faz, eles vêem assim as lutas da gente, eles passam a dar mais valor." (Diretora)

No entanto, ao falar sobre os pais que não participam da vida escolar, ela não mostra uma reflexão aprofundada sobre o assunto. Responde de forma estereotipada, dizendo que são pessoas difíceis:

"Os pais que não vêm, os que não participam são os que mais agridem, os que não participam que eu não sei porque, eu pelo menos vivo chamando, eu convido todos e tal, mas sempre tem aquele que, são ... são pessoas dificeis né." (Diretora)

Ainda assim, sua relação amistosa com os pais ficou clara também no relato destes. Além disso, a pesquisadora observou que muitas mães entravam e saíam da escola de maneira bem natural e à vontade. 


\subsection{4- A vice-diretora}

Já a vice-diretora mostrou uma outra atitude para com os pais. Ela assumiu predominantemente o discurso ideológico que coloca a participação dos pais na escola somente através de serviços prestados. Ela apontou que os pais deveriam ajudar com serviços gerais, uma vez que pouparia a escola de pagar por eles. Além disso, se não pudessem fazê-los, os pais deveriam pagar uma taxa para a escola, "o mínimo que fosse, porque a gente só valoriza aquilo que paga" (sic). Assim, ela ressalta a importância do apoio financeiro dos pais, além da sua participação em festas, como pode ser observado no seu relato:

\footnotetext{
"Quando vai ter festa nós reunimos os pais e eles vêm, participam, eles estão junto com a gente. Tem algum problema, chamou o pai, a maioria o pai vem.(...)Quando eles vêm fazer a matrícula, a gente já fala do início, a gente já dá as regras. Aqui é ... é a disciplina.......) Onde não tem ordem, só a desordem, não é?(...) A comunidade todas as vezes que a gente tem pedido a colaboração dessa comunidade, eles tem atendido, sabe? (...) Então nós pedimos, por exemplo, às vezes quando a gente tá em dificuldade, nós temos que fazer campanha...(D: financeira...?) Isso, financeira. A gente manda bilhetinho, os pais tem contribuido com a gente, muito, entendeu? Chama pra vir, pra trabalhar numa festa, pra dar uma mão, eles tão aí." (Vice-diretora )
}

Observa-se, a partir desses relatos, que a escola não pode ser vista como um grupo homogêneo de valores e idéias, e a visão sobre a relação dos pais com a escola não se coloca de forma unânime. O seu cotidiano se configura muito mais como um palco onde ocorrem confrontos e divergências.

\section{8- Os documentos escolares}

Na Proposta Pedagógica (documento confidencial cedido pela escola), destacase a afirmação de que a escola se define como laica, pretendendo valorizar nos alunos a autonomia pessoal, o senso crítico, os valores laicos e éticos entre eles: dignidade, justiça, respeito mútuo, responsabilidade, diálogo, assim como o senso de democracia e participação. Parte-se do ponto de vista que toda criança é capaz de aprender, o que impõe a meta de valorizar a diversidade entre os alunos. A proposta coloca ainda, a importância de se estimular o vínculo com o conhecimento, o que pode garantir que o aluno aprenda a aprender, saiba pensar e não somente fazer. A função da escola é colocada como sendo formar cidadãos capazes de intervir criticamente na sociedade. 
Com relação às diretrizes da escola, é importante destacar um dos parágrafos referentes às normas de gestão e convivência: “A escola não poderá fazer solicitações que impeçam a freqüência de alunos às atividades escolares ou venham sujeitá-los à discriminação ou constrangimento de qualquer ordem" (Regimento Escolar, documento confidencial cedido pela escola) Ainda, "Valorizaremos e respeitaremos o conhecimento que o aluno traz de seu convívio familiar, além de inseri-lo nos objetivos de cada componente curricular" (Plano de Gestão, documento confidencial cedido pela escola).

Outro aspecto importante da proposta pedagógica da escola, relativa ao tema do atual estudo, é a definição da função dos pais, cabendo a eles:

- Participar das reuniões bimestrais e demais convocações na escola;

- Dar apoio à escola quando se tratar de problemas disciplinares;

- Dar retaguarda ao filho nas tarefas escolares;

- Orientar seus filhos no sentido de valorizar a aquisição de conhecimento, mostrando-lhes a importância da educação para a vida.

A escola baseia-se, teoricamente, no princípio de gestão democrática, tendo os pais de alunos, o direito de participar do processo educativo, "principalmente através das Reuniões de Pais e Mestres."(Regimento Escolar)

Segundo o Plano de Gestão, os problemas enfrentados pela escola são principalmente: qualidade insatisfatória de ensino, falta de participação dos pais na vida escolar dos filhos, indisciplina e desinteresse dos alunos nas aulas, cabendo ao coordenador pedagógico estabelecer estratégias para solução dos problemas.

Com relação aos alunos, o diagnóstico se pauta nos seguintes termos:

Em relação à vida familiar, a grande maioria dos alunos vive com os pais ou responsáveis, mesmo assim apresentam problemas de carência e estrutura familiar. Boa parte dos alunos do noturno trabalham para ajudar no orçamento de suas famílias.[...] A Escola tem a preocupação de desenvolver nos alunos bons hábitos de comportamento, cuidados com a higiene e saúde (Plano de Gestão, documento confidencial cedido pela escola).

Com relação aos pais, destaca-se "o problema de falta de participação da maioria (os alunos que mais precisam) dos pais na vida escolar dos filhos, atendendo às solicitações da escola quando chamados "(Plano de Gestão). 


\section{Síntese dos resultados sobre o contexto da pesquisa: a Escola}

\section{Que escola é essa?}

- Pertence a Rede Estadual;

- Atende 1100 alunos de $3^{\mathrm{a}}$ a $8^{\mathrm{a}}$ séries (em 2001), passando por processo de transição para atender somente de $5^{\mathrm{a}}$ a $8^{\mathrm{a}}$ séries;

- Possui escassez de espaço, recursos pedagógicos, funcionários: busca soluções alternativas (convênios, reforço, ajuda de pais);

- Possui limpeza, organização e cuidado com o ambiente escolar;

- Apresenta bom desempenho pedagógico;

- Tem uma história marcada por lutas para obtenção de melhorias: união com a comunidade - RESISTÊNCIA ao que é imposto, confronto com o Estado e agentes escolares.

\section{Onde se situa?}

- Município: quase 300.000 hab., cidade industrial, migração a partir da década de 50.

- Bairros: Jardim Esmeralda (classe média, média - baixa) e Jardim Pitangueiras (casas populares)

A escola exige disciplina e os rituais institucionais são muito organizados.

Observaram-se dois modos de se exigir seu cumprimento: um mais maleável, destacando-se a figura da diretora e mães amigas da escola; outro mais rígido e autoritário, representado principalmente pela vice-diretora.

Projeto "Amigos da escola": funcionando bem. As mães atuantes mostraram ter tempo e desejo de exercer essa função. Apesar de ter uma origem ideológica, essa presença de pais na escola pode dar uma grande contribuição, uma vez que eles pareceram fazer uma mediação importante entre a escola e as famílias. 


\section{Como a escola percebe os pais de alunos?}

Foram observadas essencialmente quatro maneiras:

$>\quad$ Prescrições quanto ao trabalho das famílias:

- $\quad$ os pais devem auxiliar a escola com serviços prestados ou dinheiro. Ênfase no cumprimento das normas escolares (Vice-diretora);

- $\quad$ os pais devem participar das reuniões, ajudar nas tarefas escolares, apoiar a escola quando houver problema disciplinar, passar para os filhos o valor da aquisição de conhecimentos (Proposta pedagógica).

$>$ Discurso de "famílias desestruturadas", que precisam ser normalizadas. Ênfase no que os pais não estão fazendo:

- os pais são ausentes, não resolvem os problemas dos filhos, não acompanham sua vida escolar, não se interessam (Professores);

- $\quad$ os pais que "mais precisam" não participam da vida escolar dos filhos (Diretora, Plano de Gestão);

- os pais não conseguem educar os filhos, não valorizam o estudo, atrapalham a vida escolar dos filhos (Coordenadora).

$>\quad$ Perplexidade diante de algumas situações familiares e dificuldade em saber como agir (Professores).

$>\quad$ Abertura à participação dos pais e sensibilidade aos problemas comunitários (Diretora). Busca de valorização do conhecimento que o aluno traz de casa (Plano de Gestão). 


\section{Os documentos escolares}

Estão presentes slogans modernos nas bases norteadoras da ação escolar: autonomia, respeito à diversidade, aprender a aprender. A escola pretende ensinar os alunos a pensar, formando cidadãos críticos (Proposta pedagógica).

Regimento escolar: A escola não poderá fazer solicitações que impeçam a freqüência dos alunos às atividades escolares ou sujeita-los à discriminação e constrangimento.

MAS:

Não parece estar havendo um diálogo reflexivo entre a prática cotidiana e as bases norteadoras da ação escolar. Talvez essa fosse uma ação importante para que se conseguisse solucionar as dificuldades de forma efetiva.

Um dos problemas da escola, identificados no plano de gestão foi a falta de participação dos pais na vida escolar dos filhos (“os que mais precisam”, dizem). Aqui cabem algumas questões:

$>\quad$ que participação é essa que a escola espera?

$>\quad$ quem são esses pais que mais precisam?

$>\quad$ do que eles precisam?

As funções dos pais, descritas na proposta pedagógica, são estritamente ligadas à exigência de um posicionamento a favor da escola. Parece ser exigido um alinhamento ao pensamento hegemônico:

os pais devem mostrar o valor da escola aos filhos (parece que a aqui a palavra valor poderia ser facilmente substituída pela palavra poder. Poder de um saber dominante). 


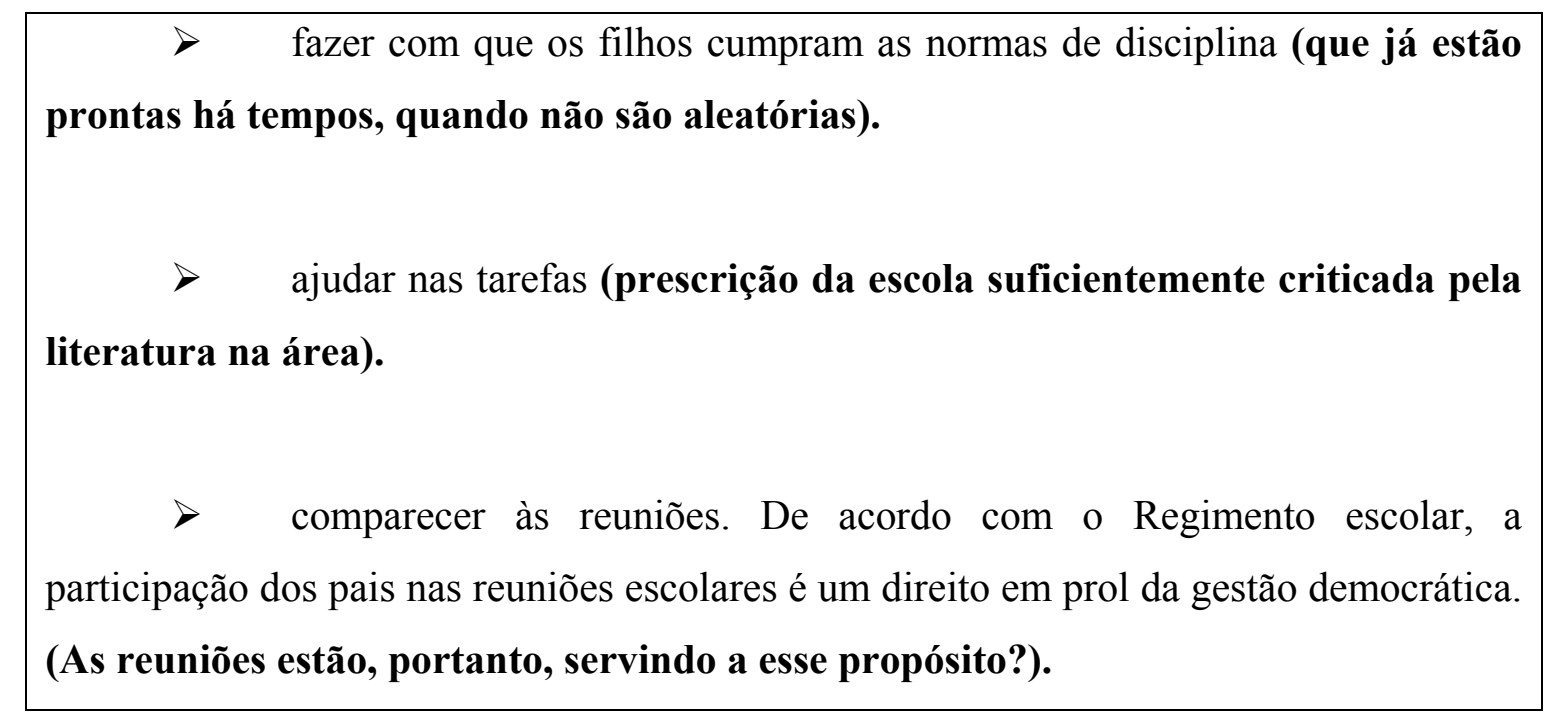

\section{4- As famílias dos entrevistados}

Essa seção tem como objetivo, num primeiro momento, contextualizar as famílias das pessoas entrevistadas segundo sua constituição, história, local de origem, escolaridade dos pais, ocupação profissional dos pais e dificuldades sócio-econômicas das famílias. Esses dados foram obtidos nas entrevistas individuais com o pai, a mãe ou o responsável pelo aluno. A caracterização geral das famílias pode ser visualizada no Quadro 3, na próxima página.

Em seguida, serão apresentados o contexto das entrevistas (a partir dos dados do Diário de Campo) e sua análise geral.

Foram entrevistados um pai, dezenove mães e uma avó, cujas idades podem ser observadas a seguir:

$\begin{array}{llllll}\text { Elza - } & 28 & \text { Gisele - } & 34 & \text { Cibele - } & 43 \\ \text { Ilda - } & 31 & \text { Maria - } & 35 & \text { Inês - } & 43 \\ \text { Valéria - } & 31 & \text { Rafaela - } & 38 & \text { Rita - } & 45 \\ \text { Silvia - } & 32 & \text { Luzia - } & 38 & \text { Jerusa - } & 45 \\ \text { Sandra - } & 33 & \text { Fabiana - } & 39 & \text { D. Célia (avó) - } & 46 \\ \text { Roberta - } & 33 & \text { Carolina - } & 41 & \text { Mauro - } & 49 \\ \text { Rose - } & 34 & \text { Mariana - } & 41 & \text { Shirley - } & 49\end{array}$




\section{1 - Constituição familiar}

Como pode ser observado no Quadro 3, na página anterior, a maioria das famílias, 57,1\% é tradicional (com a presença de pai e mãe), 14,3\% são reconstituídas (não sendo a primeira união ou do pai ou da mãe, ou de ambos) e 28,6\% são monoparentais (somente uma das pessoas do casal parental é responsável pela família).

Em apenas cinco famílias há filhos que já saíram de casa. Além disso, em sete famílias há agregados que vivem juntos, sendo estes: avós, sobrinhos, netos, amiga, irmãos e parentes em geral.

\section{2 - História das Famílias}

Alguns entrevistados se referiram ao tempo de união do casal, que variou entre 10 a 32 anos (Quadro 3, p. 120-1). Outros enfatizaram a história da união e/ou separarão como cônjuge. Os relatos indicam, ainda, alguns arranjos familiares não tradicionais:

"O Hirto tem, é, 20, 21 ano mais velho que eu.(...) Amigô comigo eu tinha 18 ano.(...). A Mara era, era piquinininha. (D: Ah, a Mara não é filha dele, então?) Não. (Cátia?) A Cátia é.(...) Eu, como, como diz, eu comecei aqui, trabalhando pro Hirtão.(...) Eu ajudava a mãe dele... O dia que ela ia lavá a casa, fazê uma faxina, assim... Num tinha nada a vê, assim, eu e ele. Mais só que a gente ia pro Som de Cristal, pros lugar... E, e ele pegava e me dava carona pra voltá. As vezes tava lá, a gente ficava junto, dançava junto, tomava uma cerveja junto, né?(...) É. Foi aconteceno, até a gente ficá junto. (...) Depois já foi morá junto, eu já tomei conta, eu já passei a tomá conta de tudo, né? (...) Eu, eu quando vim pra cá eu num sabia nem faze um arroiz. Foi o Hirtão que me ensinô a cozinha. Né? Foi tudo ele que me ensino a fazê.(...) Nóis aprontamo muito..." (Elza)

"Eu separei eu fava grávida dele de treis meses. (D: E casou com quantos anos?) Dezenove. (D: E esse primeiro casamento durou quanto?) Durou pouco tempo. Eu não tive sorte prá isso não.(...) Agora não dá certo, prefiro ficar sozinha mesmo e criar esses menino." (Roberta)

"(D: Vocês ficaram casados muito tempo, ou não?) 24 ano. (...) Dai, quando eu conheci meu marido, meu filho tinha 3 aninho, o mais velho. Que ele não é filho do meu marido, o primeiro, não.(...) Peguei pra acabá, de criá, né? Porque ele era uma criança, ainda, né? Ele tinha 15 anos.(..) Meu marido.(...) É cinco ano que eu sou mais velha que ele. E nóis vivemo em paz." (Dona Rita)

A Inês relatou uma história de vida difícil, voltada para a criação dos filhos:

"Meus minino foi assim, diferença dum ano de diferença um do outro. Ai vai aquela escadinha.(...) E sempre a gente trabalhando, nas fazenda, cê 
sabe que é dificil né?(...) E sempre pró interesse dos fio da gente, né? Que tudo que ocê vai fazê cê pensa nos filho, né? Nóis vamo dá o melhor pros fio da gente, né?" (Inês)

A Rafaela e a Cibele relataram a história de adoção dos filhos:

"Inclusive o Hélio, ele não é meu filho verdadeiro, A mãe abandonou e ele ficou comigo. Mas é assim como meu filho. Não é no meu nome nada, mas tá comido desde pequenininho. Ele me chama de mãe, o pai de pai e é normal. Assumimo como filho, porque o pai não tinha condições, assim, porque mexia com droga, essas coisa, né" (Rafaela)

"Bom, na verdade são, são, éramos 5 na famíla, né? Depois, meu pai morreu, e do segundo casamento deixô três criança. Como a mãe havia perdido a guarda, eu peguei os três pra criá. A família cresceu. (D: Cê tem quantos, cê tinha quantos filhos?) Eu tinha três, agora eu tô com seis, né? Então, são irmãos, filhos, né? (...) Foi muito bom, viu? (...) Parece que eu nasci pra cuidá das criança de, de, sei lá. Eu gosto de família grande..." (Cibele)

Já o Sr. Mauro e a Carolina não se referiram à história da família atual, mas

falaram de suas famílias de origem, talvez por terem vivido algum grau de sofrimento:

"Meu pai e a mãe Já faleceu.(...) Pai não, vamos ser realista, padrasto. Ele era da cor branca. Agora o pai biológico mesmo eu não sei quem que é não. Não, não sei quem é. Essa história eu sabia desde quando eu tinha meus 12, 13 ano. Eu comecei a procurar, ver meu registro, marcava cor branca, eu não sou branco, que negócio é esse?(...) Ele nunca me faltô com carinho, cum nada (...). Só que isso me deixô cum ciúme pra com os outro quatro irmãos. Essa que é a realidade." (Sr. Mauro)

"Eu tive meus, os meus pais tiveram problema de incompatibilidade de gênio. E, financeiro, também. De maneira que não, ai, eles tiveram que nos interná em colégio de freira. E, e assim. E eu fiquei nas freiras(...). (D: Mas eles iam visitar vocês?) Não." (Carolina)

\section{3 - Local de Origem dos Pais}

Como os entrevistados responderam sobre o próprio local de origem e, também, o do cônjuge (quando havia) obteve-se dados referentes a 36 pessoas. Destas, a maioria é proveniente de Minas Gerais (aproximadamente 36,1\%); 13,9\% são provenientes de outras localidades do Estado de São Paulo; 11,1\% são provenientes do Paraná e 5,5\% vieram de outros estados. Portanto, somente 33,3\% são provenientes da própria cidade. Esses dados podem ser observados no Quadro 3 (p. 120-1) e através de alguns relatos dos entrevistados: 
"Meu marido é do Pernambuco, do norte. E eu sou de C. (sul de Minas Gerais. (...) Quando eu vim pra cá eu tinha 15 anos. Tem uns 30 ano.(...) Nóis viemo embora da roça, né ?(...) Aí nós viemo pra trabalhá e ficamo até hoje.(..) Eu tenho vontade de voltá pra minha terrinha. Ah, sempre tenho saudade. Um lugarzinho de paz, né? Sossegado. Cidade não é muito bom. Sei lá, não gosto." (Dona Rita)

"...nóis somo mineiro, né. Nóis somo assim, meu marido é de C., eu sou de I..(...) Porque quando eu vim pra cá eu fava com 16 ano, não me lembro bem." (Rose)

\section{4 - Escolaridade dos pais}

Têm-se dados a respeito da escolaridade de 36 pessoas, pais e mães de alunos. Se agrupados somente em três níveis de escolaridade, os dados trazem o seguinte resultado: $36,1 \%$ dos pais têm nível de escolaridade acima do segundo grau, 33,3\% podem ser classificados como estando dentro do segundo ciclo do ensino fundamental $\left(5^{\mathrm{a}}\right.$ a $\left.8^{\mathrm{a}}\right)$ e $30,6 \%$ dos pais atingiram no máximo a $4^{\mathrm{a}}$ série. Esses dados podem ser observados no Quadro 3 (p. 120-1).

Alguns entrevistados justificaram o fato de terem um baixo nível de escolaridade como pode ser verificado nos relatos a seguir:

“Não nasci pra escola, não (risos)” (Dona Rita)

"Ah, eu sô assim, eu, eu come, eu estudei, né? Um pouquinho. Só que era assim, meu pai mudava muito, esses pai que num dava muito bola, né? Começava estudá... Na mesma hora ele: "Ah, nóis vamo mudá. Aqui num tá dano certo. Nóis precisa i caçá mais um curso de vida melhor." Ia embora. Estudava nada, né? Ai eu num tivo como eu cabá de estuda. Então, eu só sei mesmo assiná meu nome. $O$ corretio é fala assim: eu só sei assiná meu nome. Eu num sei nada, não (rindo) mais, sempre quando tem uma escola perto, eu quero i pra mim caba de aprendê, né?" (Inês)

"(D:E do Hilton, você sabe como é que foi a história dele na escola?) Ah, que o pai dele é muito severo. Num dexava i na escola. Era tipo, assim, o seu Zé era, como diz, o apelido era seu Zé linguiça, né? Ele era lingüicero.(...) Aí, 3 hora da manhã ele já botava o menino em pé. Na época ele tinha 8 ano, 9 ano(...) Já botava ele pra dispelá porco lá e, e limpá. (...)E, e acho que ele fico um pouco traumatizado com isso, e ele, o que ele aprendeu, foi até o terceiro ano. Né?(...) Só que, com a história de tê que vendê lingüiça e recebê, levá o dinheiro certinho que senão apanhava... (...)Ele ficô ótimo na matemática." (Elza)

"Comecei a trabalhá com 13 ano. Ai chegava em casa, tinha que chegá, tomá banho e estuda, né? Ai morava longe, né? Era quase uma hora de caminho da escola em casa. Chegava em casa era meia noite. No outro dia num agüentava de canseira." (Silvia) 


\title{
4.5 - Ocupação Profissional dos Pais
}

As ocupações profissionais dos pais e mães são bem variadas. Dos 15 pais quê se tem informação, seis exercem trabalho braçal, como pedreiros, matador de vaca, trabalhador em "roça" e caminhoneiro. Cinco exercem funções "não-braçais" como: vendedor, comerciante, funcionário de empresa estatal e auxiliar de finanças. Três pais são operários em fabricas e um é aposentado.

Com relação às 21 mães, seis trabalham sem sair de casa, costurando sapatos ou fazendo alguma atividade manual para vender. Cinco não possuem trabalho remunerado (do lar). Três mães são operárias em fabricas, três são funcionarias públicas, duas são vendedoras e uma é comerciante. Somente uma mãe trabalha como doméstica. Esses dados podem ser observados no Quadro 3 (p. 120-1) e nos relatos dos entrevistados.

Observa-se que a inserção de muitos pais e mães no mercado de trabalho é frágil, havendo falta de estabilidade financeira e de emprego, uma vez que a maioria possui trabalho braçal:

\begin{abstract}
"Quer dizê, ele já, ele já num tem trabalho fixo há muito tempo, né? Porque ele, ele era matador de vaca, né? (...) Mais depois que dismontô o matadô... Ai, como diz: ai num, num pode mais, né? (...) Ai, agora, agora ele tá só fazeno bico. (...) E, quando tem, né? (...) Nois limpa mocotó pra fazê geléia.(...) Eu ainda vô, dia de Quinta, na casa do meu, do meu cunhado, né? Limpa lá." (Elza)

"A minha minina, essa mais véia trabaia no $S$. (fábrica de sapato). A outra trabaia de babá, também. O meu minino trabaia em fabriqueta e o esposo trabaia em roça (...) Tudo braçal. (...) E eu também sô na luta. É roça” (Inês)
\end{abstract}

Além disso, observa-se, em alguns casos, uma grande dificuldade em conciliar o trabalho com o cuidado dos filhos e da casa, o que foi principalmente observado em famílias monoparentais, como no caso da Roberta:

"Eu tava desempregada, agora que eu falei: vou lutar, vou enfrentar. (...) Eu comecei a sair fora, prá trabalhá prá fora. E ai não deu certo por causa deles, dos menino.(...) Como não dava tempo de eu vir almoçar, eu achava que eles iam pra escola. E tavam faltando demais da escola. E eu achando que eles tavam indo normal.(...) Num dava tempo nem de olhar nos caderno. Ai eu falei: num tem jeito, vou ter que sair mesmo." (Roberta)

Também a Gisele mostrou-se pesarosa por ter tido que parar de trabalhar para cuidar dos filhos: 
"Ai eu sai, parei de trabalha prá cuida deles (dos filhos). Tem hora que eu me arrependo, eu falo: eu num divia tê parado. Na hora do financeiro assim, não que a gente num tá bem. Dá prá gente vivê. E ele aposentou até que bem, mas tem hora, marido, cê sabe, é homem. Mulher gasta demais, mulher é gastadeira." (Gisele)

Um outro aspecto abordado foi relativo ao trabalho em fábricas de calçado, já que a economia da cidade gira em torno dessa indústria e são várias as mães que vivem essa realidade, como pode ser observado a seguir:

"É, porque aí, esse serviço de sapateira é dose, viu? Nossa Deus, não é fácil (...) Ai, cansa. Mexê com sapato o dia inteiro.(...) E ainda o serviço em casa. E assim vai...(...) Mais aí, aí eu fico cum raiva, eu começo a chorá.(...) A gente que precisa trabalhá é difícil. Tem hora que eu fico meio revoltada.(...) Dá vontade de largá tudo, tudo, largá tudo mesmo e sumir." (Silvia)

"Nóis trabalha em casa. Costura sapato, que cansa também. O sapato é dia e noite, né? Você pega sapato prá costurá... (...) Você tem que trabalhá muito pra ganhá pouco, né? Porque o sapato, o par, é 50 centavos. Prá costurar o par, conforme o sapato, você ainda faz 24 par. Mas conforme o sapato você faiz 12 par e olha lá.(...) O dia inteiro, até a noite." (Valéria)

"(D: A senhora trabalha com costura de sapato, faz tempo?) É costura manual faiz tempo. (...) Faiz 24 ano.(...) Eu já trabalhei nas fábrica, registrada, às vezes umas não registra, outras registra, e sempre trabalhando.(...) Comecei trabalhá em casa porque é mais dificil a gente saí prá trabalhá fora, né?" (Jerusa)

"E continuei trabalhando em fábrica de calçado até fevereiro. Agora que eu tô desempregada. Ai, num quero mais mexer em sapato mais não. Quero fazer qualquer coisa, menos sapato. É cansativo menina, nossa, um serviço sujo." (Sandra)

\section{6 - Dificuldades sócio-econômicas das famílias}

Algumas famílias passam por sérias dificuldades financeiras, o que causa sofrimento e desespero, como pode ser verificado no relato a seguir:

"Eles (os filhos) acham assim, que eu tenho que dar aquilo prá eles: mãe me dá dinheiro. Eu digo: eu não tenho, (...) Os pequeno mesmo, é difícil. Pede, direto. Até o pequenininho, ele levanta de manhã, ele já mostra no armário que ele quer pão. Se não tiver é o maior show (...) É difícil, o dia que tem dá, o dia que não tem, fazer o que? (...) E muito difícil, tem hora que dá desânimo. Teve vez de eu pensar assim... Agora não, graças a Deus que Deus... Já teve vez de eu pensar... Teve uma época de eu estar pensando: eu vou acabar com tudo. Eu não agüento mais ver esse sofrimento. Eu acabo com os menino e depois eu vou e acabo comigo. Nem eu nem eles. Era uma coisa, menina, esse pensamento vinha direto. Era direto." (Roberta) 
Verificou-se, também, a dificuldade de um pai em arrumar emprego por ser mais velho e, no relato seguinte, observa-se que essa dificuldade foi devida à falta de escolaridade:

"Hoje eu tô nessa fabrica atualmente porque é padrinho. E hoje eu tenho 49 anos. Com esse país com essa mente desse tamaizinho, 30 ano é velho, burro, num sei" (Sr. Mauro)

"Porque experiência hoje não conta. O que conta é seu diploma do SENAI. As vezes cê num sabe nada, cê num sabe nem emparafusar, mais cê tem um curso do SENAI e ai eles te pegam. Meu marido perdeu muito emprego por causa, disso. Os 30 ano de experiência que ele tem, na profissão dele, num vale de nada prá ele.(...) Soldador mecânico. Num vale nada. "O senhor tem curso do SENAI? Ah não, nóis queremo uma pessoa de curso." E meu esposo tem uma experiência incrivel. Trabalhou dentro da Petrobrás. Num manda nada, nada, nada." (D. Célia)

As dificuldades sócio-econômicas de algumas famílias atrapalham a vida escolar dos filhos, por exemplo, quando o aluno é obrigado a trabalhar, o que provoca rupturas no seu processo escolar. Além disso, há dificuldades em comprar o material escolar e o uniforme, como pode ser visto nos seguintes relatos:

"Ele (filho) estudou aqui até a oitava, né? Ai teve, na fábrica, o patrão era muito enjoado, nunca deixava sai na hora da escola.(...) Quando chegava já tinha começado a primeira aula. Então não dava. Ai ele não quis ir mais." (Dona Rita)

"Sou eu sozinha. Eu tô com dificuldade de material de escola, essas coisa. Mas é tão difícil. Até hoje eu não comprei. Agora eles mandaro pedir. (D: Você conseguiu bolsa escola?) Consegui. Mas mesmo assim ainda não dá, porque é pouco prá poder... Ajuda é lógico, uma ajudinha. (...) Não dá.(...) Igual o Rafael, o Rafael começou a trabalhar aqui numa banca. Eles tão exigindo que ele vai de todo jeito... Eles querem que ele faça recuperação, quer que ele faça física. E o homem não quer deixar ele sair nesse horário. E eu não posso perder o serviço dele também.... Faz falta. Ele ganha pouco mais já serve. (...) Ele precisa me ajudar também. (...) Esses dia a Taís também fava falando: mãe muda eu de escola? Eu falei: porque? Porque eu quero mudar o horário. A tarde prá mim é melhor porque ai eu olho o nenê prá senhora. Eu falei: não, você vai ficar ai mesmo.(...) Nossa, se não fosse a Tais. A Tais é uma mão prá mim. Se eu precisar sair, ela que cuida desses menino prá mim. (...) Porque eu tava com muito problema e ela fava faltando. (...) Por causa dos menino. "(Roberta)

"Nunca mandei a, a Mara sem uniforme. Apesar de sê, o uniforme dali, eu acho que é um absurdo. Um absurdo o preço. Tipo assim, prá gente que, que é pobre, vamo fala assim claro, direto, prá gente que é pobre, comprá duas camiseta, fica, fica apertado.(...) Ocê precisa de pelo menos duas calça jeans e uma bermuda.(...) Cê vai gastá no mínimo 40 real prá compra... (...) A lista de material é aquele mundarel de trem. Vai mais 40, 50 real. Prá quem vive de bico, se eu fô comprá tudo isso no mêis, eu vô faze o quê? (...) Eu vô passá necessidade. (...)Esse ano eu num comprei camiseta, ainda. (...)Meu marido num ganha isso!(...)Eu queria 
mandá minha fia pa escola que nem uma princesa. Era minha vontade. Que ela tá moça, né? Tá mocinha. Vaidosa, mais...(...) Como é que eu faço? " (Elza)

"Que teve um ano que a gente tava parado, desempregado, todo mundo, ai eu fui lá, pedi os material, veio os material deles tudo.(...)E, eu tive que i lá, né? Pedi porque ela(diretora) não sabe as condições da gente lá dentro de casa, né? Eu peguei, não tive condições, eu fui lá e falei com a diretora, né? Ela falou; "Não, se você tá desempregada e ele (o marido) tá, a escola tendo aqui, fornece, né?"(...) Uai, a gente fica meio acanhada, né ?(...) Sei lá, a gente fica meio constrangida, né? Porque a gente nunca espera por isso, né? Tá desempregada. Mas eu falei: "Uai, fazê o quê? Eu não tenho como comprá mesmo, então eu vô lá." (Silvia)

Um outro fato que chamou a atenção é que uma das entrevistadas relatou que recusou a bolsa-escola, tendo sido escolhida na escola para recebê-la (devido as dificuldades de criar sozinha os oito filhos), porque achou que outras famílias poderiam estar precisando mais de ajuda financeira. Sua justificativa foi de que ela pelo menos possuía casa própria e pediu para que reencaminhassem a bolsa para uma família que pagasse aluguel. Seu relato pode ser observado a seguir:

"Inclusive, eu até ganhei a bolsa escola, né? Que eles me chamaram lá, né? Selecionaram umas crianças, e a minha foi uma. Só que eu não quis a bolsa, porque eu, eu acho assim, que tem gente mais necessitada de que eu. Criança mais carente, que sempre tem aqueles mais pobrezinhos. Então eu num quis a bolsa escola. (...) Eu já tenho a minha casa própria, minha, pra mim morá. Não é lá grandes coisas mais é minha, né? E até assim, não tenho lá uma vida sacrificada. Tenho até assim, uma vidinha muito boa. Eu acho que tem gente que trabalha dia e noite pra comê e pagá um aluguel e assim mesmo num dá nem conta.(...) Não foi orgulho, não, nada. É porque eu achava que tinha gente que merecia mais do que eu." (Dona Rita)

\section{7 - Diferenças entre a educação que receberam e a que passam aos filhos}

Alguns entrevistados destacaram a diferença entre a educação que receberam e a educação que passam para os filhos, como pode ser observado nas falas a seguir:

"Nossa, foi super diferente (...) Minha mãe tentava ajudar nóis, mais como? Ela não podia falar nada.Porque na época, ele (pai) ainda bebia,minha filha. Era feio. Nós sofremo, né. E ela sofreu, mas sofreu mesmo. Agora hoje, hoje as criança não apanha. Se a gente der um tapa, eles próprio fala: eu vou chamar a polícia, né (...) Então hoje a gente nem batendo no próprio filho pode, sabe, educar. Porque você não vai machucar, é lógico.(...) Nóis apanhamo demais. Se fosse na época de hoje meu pai tava preso há muito tempo. A gente apanhava de corda de nylon, vara de marmelo. Colocava todos num quartinho e ia passando de um em um...(...) Se um fizesse uma coisa, todo mundo apanhava dele." (Roberta) 
"Então, hoje cê dá ordem prum filho, quando cê vira as costa ele já caiu pra rua, né? Lá não. Lá era assim, pegava um rebento, dava uma rebentada na gente e rebentava, né? Porque rebento que bate nesses cavalo. (D: O que é de batê em cavalo?) Rebento, né? Dava uma, o sangue escorria, né? Porque cortava. Então a gente, pra não apanhá, porque apanhá não presta,(...), então já fazia as obrigação.(...) Porque ele (pai) era muito bravo." (Dona Rita)

"Não tinha esse negócio de eu vou sair agora. Não, não sai. Vai ter que voltar.(...) Ah, mais eu cheguei da escola agora. Não quero saber, cê vai sentá aí. Errou nisso daqui. Vai sentá e estudá. Almoça, dá um tempinho, vai estudá e acabou. E a gente obedecia porque senão vai apanhá(...) Agora hoje é o contra. Ah, eu vou ali. Faiz uma, duas hora e num voltou até agora. Ai minha esposa fica com medo deu pegá e batê." (Sr. Mauro)

\section{8 - Contexto e Análise geral de cada entrevista}

\section{Entrevista com Rafaela}

Contexto:

Após a apresentação da pesquisa, a Rafaela foi muito solícita e interessada, se propondo que a entrevista fosse feita naquela mesma hora. A pesquisadora e a mãe entraram pelo fundo, passando pela cozinha bem equipada, se sentando no sofá da sala de estar. A mãe da entrevistada estava na casa e ficou cuidando do menino de dois anos. Ele brincou com os lápis e papéis que a pesquisadora havia levado, enquanto sua mãe estava ocupada com a entrevista.

A casa fica no Jardim Esmeralda, bairro de nível sócio-econômico bom e se localiza bem perto da escola. Não está pintada por fora e tem um aspecto de construção parada. Mas o terreno é grande e a casa também é de bom tamanho, com cômodos amplos e bem mobiliados, estando pintada por dentro.

Análise geral:

No inicio da entrevista, Rafaela falou mais dos aspectos positivos da escola, mostrando que é bem participante, que tem uma relação próxima com a diretora, tendo um discurso parecido com o da escola com relação à não participação dos pais "que mais precisam". Ela mostrou-se muito agradecida à escola, por tudo que esta faz pelo seu filho, atribuindo todos os problemas a ele (a justificativa é o fato de que seus pais biológicos usavam drogas). 
$\mathrm{Na}$ medida em que a conversa foi acontecendo, a mãe fez algumas críticas e mostrou estar atenta à maneira implícita com que a escola afugenta alguns pais. Falou que percebe que os pais pobres e negros são tratados de maneira diferente nas reuniões. Apesar de fazer parte do grupo mais favorecido economicamente, dentre os pais de alunos da escola, ela percebe e aponta onde as discriminações sociais e econômicas acontecem.

Dessa forma, observa-se no seu relato, dois movimentos: um de apoio e repetição do discurso hegemônico e outro de crítica às ações que muitas vezes passam desapercebidas e que contribuem, para a exclusão social dentro da escola.

\section{Entrevista com Maria}

Contexto:

A pesquisadora passou na casa no meio da tarde, mas a Maria não estava e as filhas a orientaram a voltar depois das 17 horas. Quando a pesquisadora voltou, a mãe veio cumprimentá-la no portão de maneira muito receptiva e colaborativa. Preferiu fazer a entrevista naquela hora mesmo, convidando a pesquisadora para entrar e se sentar na sala. As filhas entravam e saiam da casa e às vezes se sentavam ao lado da mãe.

Durante todo o tempo a panela de pressão esteve funcionando, provavelmente uma das filhas estava fazendo o jantar.

A casa fica numa rua cheia de casas grandes, na parte do bairro onde a maioria é classe média. Mas é bem mais simples, contrastando com as demais. É pequena, sem reboco e pintura, com mato ao redor. Por dentro, a casa também não tem pintura, as paredes são muito emboloradas, o piso é de cimento e os móveis são velhos (sofá rasgado). Mas o aspecto geral é de um ambiente interno bem cuidado: cortina, mesa, altar com toalha e uma rosa num copo.

Análise geral:

A Maria se mostrou tímida no início conversa, respondendo às perguntas com poucas palavras, não dando continuidade aos assuntos em pauta. Na maior parte do tempo ela teceu elogios à escola, colocando os problemas fora da mesma. Sua maior crítica foi quanto à progressão continuada e ao sistema de ensino na escola pública, que não dá chance aos alunos de ingressarem numa faculdade pública. 
Um outro assunto no qual ela se soltou bastante, sendo bem enfática, foi sobre a luta dos pais para conseguirem uma outra escola no bairro. Ela se envolveu e participou muito do movimento e a emoção transpareceu enquanto ela relatava esse fato.

Especificamente quanto à escola e seu funcionamento, sua única crítica foi com relação à reunião de pais. A princípio ela elogiou, mas de forma vacilante. Quando a pesquisadora apontou que ela não estava sendo convincente, ela começou a falar do seu desânimo e descrença quanto à produtividade das reuniões, confessando que não faltava em nenhuma, somente para não desagradar a diretora.

\section{Entrevista com Shirley}

Contexto:

A Shirley ficou bem relutante em participar da entrevista, dizendo que não tinha muito o que falar. Quando a pesquisadora fazia uma pergunta temática, ela falava que não pensava nada, que não tinha nada a dizer. Era dado mais um tempo para ela pensar o ela voltava a repetir que não pensava em nada. Foi difícil fazer a entrevista, mas aos poucos ela foi se soltando. Por fim, ela falou muita coisa.

Ela mora numa casa grande, entre os bairros Jardim Bela Vista e Jardim Pitangueiras. A sala onde foi feita a entrevista é grande, não estando pintada. Na fachada tem dois portões grandes de ferro, com entrada para dois carros. Durante a entrevista, estava também em casa o neto que ela cuida às tardes. Depois chegou a filha.

Ela olhava sempre para o gravador e no final disse: "depois você vai rir de mim ouvindo minha voz nessa fita". Ela parece ter ficado constrangida, apesar de ter concordado com a gravação.

Análise geral:

A Shirley se diz uma pessoa bem reservada, não conhece ninguém no bairro e não se dispôs a participar da entrevista em grupo. Disse logo que não poderia. No início da entrevista, disse não saber nada sobre o assunto da escola da filha, talvez numa tentativa de se preservar de uma exposição que ela não sabia ainda, se iria prejudicá-la diante da escola.

Ela pareceu procurar manter-se acrítica, aparecendo algumas contradições em seu discurso somente quando estava mais solta e à vontade com a entrevistadora. Ela 
não dava continuidade aos temas conversados, interrompendo-os bruscamente, parecendo estar numa postura defensiva. No final, mesmo mais à vontade, ela ainda manteve esse movimento contraditório, oscilando entre mostrar-se e esconder-se.

\section{Entrevista com Luzia}

Contexto:

Luzia mora em uma casa grande, própria, na parte nobre do Jardim Esmeralda. A sala onde foi feita a entrevista é bem ampla, com cortinas, um bar; sofá e televisão grande. Na garagem tinha um carro. Ela foi muito receptiva e, no final, pediu que a pesquisadora esperasse, que ela gostaria de servir um café. Ela mostrou-se muito interessada em participar dos encontros grupais, mas disse que teria problema com os horários, pois trabalha fora o dia todo. A família possui uma pequena fábrica na cidade. No final, Luzia disse que fica só trabalhando e que achou muito bom parar um pouquinho pra conversar, pra pensar nas coisas, nos assuntos (sic).

Análise geral:

Luzia só teceu elogios à escola, principalmente quanto à disciplina, segurança e organização. Quanto às professoras, relatou somente aspectos positivos, reafirmando o tempo todo que estava sendo sincera, que achava a escola excelente. As críticas que fez foram relativas às escolas anteriores dos filhos.

Ela atribuiu a responsabilidade pelas dificuldades dos alunos na escola aos seus pais, ressaltando a defasagem cultural de algumas famílias, colocando isso como algo vergonhoso e impeditivo da aprendizagem dos filhos.

Luzia mostrou grande afinidade com os valores hegemônicos da escola e pareceu defender essa posição.

\section{Entrevista com Sr. Mauro}

Contexto:

Quem recebeu a pesquisadora foi o pai do aluno, que estava em casa à tarde. A pesquisa lhe foi apresentada e ele logo falou que poderia participar porque "o ano 
passado havia participado muito da escola" (sic). Foi muito receptivo e falante, fazendo com que a pesquisadora se sentisse à vontade, chamando-a logo para entrar, se mostrando bem interessado. Sua casa fica bem no meio do Jardim Pitangueiras, na parte mais pobre do bairro, onde as casas são todas parecidas. A casa é muito simples, tendo um muro não terminado na frente, de tijolo baiano à vista. Por dentro, o único móvel era um sofá novo. A casa estava no reboco, sem pintura e a porta da frente estava sem vidros, estando fechada com papelão. A cobertura da varanda era afeita de lona cor de laranja.

Sr. Mauro se alongou bastante na conversa e, ao final da entrevista, agradeceu muito, mostrando interesse em continuar se houvesse mais tempo.

Análise geral:

O inicio da entrevista esteve permeado de discursos sobre o trabalho, dificuldade de emprego e exaltação da própria capacidade. Ele, no momento da entrevista, não estava trabalhando (não ficou claro se ele estava desempregado ou afastado). Talvez por isso estivesse precisando falar de si mesmo. Quando inquirido sobre os professores do filho, Sr. Mauro revelou uma visão idealizada (profissão bonita). Logo em seguida passou a falar das dificuldades do filho, apontando causas orgânicas como justificativa do problema. Para "melhorar" o filho, ele já tentou bater, tentou, também, colocá-lo na APAE.

Quando inquirido sobre a professora, ele contou que é chamado na escola, para resolver os problemas e tentou mostrar que faz o que pode para o filho melhorar. Ficou clara sua impotência. Ele mostrou uma leve crítica, não confessa e vacilante. Ele mostrou até uma busca, às vezes sofrida, para se enquadrar e ser bem visto pela escola. Da mesma forma, quando inquirido sobre ela, sua primeira fala foi sobre o esforço que faz para acompanhar o filho e ajudar a resolver os problemas. Além disso, ele mostrou como ajuda o filho a fazer trabalhos escolares. Concluindo, seu discurso é permeado de relatos pessoais, ficando claro o sofrimento e o desejo de ser valorizado. Com relação ao filho, ele mostrou perceber seu potencial, mas afirmou defender sempre a escola, ("o filho dá problema na escola")

Parece que no inicio da entrevista ele não tinha muita clareza das próprias críticas. Algumas reflexões sobre o filho foram acontecendo no decorrer da entrevista. 


\section{Entrevista com Valéria}

Contexto:

Quando a pesquisadora chegou na casa, a Valéria estava saindo para a escola, porque havia sido chamada lá para resolver o reforço da filha. A pesquisadora the deu uma carona e marcou de voltar mais tarde. Ela foi muito receptiva, convidando a pesquisadora para entrar, antes mesmo que lhe fosse explicado o motivo da entrevista. A conversa aconteceu numa sala pequena, onde estavam sentadas também a mãe da Valéria, uma visita e seis crianças, todos em somente dois sofás. Não havia mais móveis na sala, além de uma televisão antiga.

A casa fica na parte mais pobre do bairro Jardim Pitangueiras, não tem muro e é feita com tijolos baianos, sem reboco. Não tem forro e é bem pequena para o número de pessoas que moram lá (cerca de vinte).

A Valéria se mostrou muito disposta, disponível a colaborar, apesar de um pouco tímida. Sua mãe tentava entrar na entrevista sempre, dando sua opinião, o que, muitas vezes, inibia a Valéria. No entanto, não havia outro espaço na casa onde a entrevista pudesse ser feita com privacidade. Então, a pesquisadora tentava preservar a opinião da Valéria, sempre que sua mãe se antecipava, voltando a pergunta para ela.

Análise geral:

A Valéria mostrou-se tímida no início da entrevista, falando pouco e respondendo às questões de forma breve. Ao ser inquirida sobre os professores, justificou as dificuldades da família, revelando uma postura defensiva.

$\mathrm{Na}$ medida que a conversa foi acontecendo, ela esboçou algumas críticas, mostrando um pouco as dificuldades que vive na escola. Logo em seguida, ela reafirmava os aspectos positivos, atribuindo a culpa pelas dificuldades da filha a problemas familiares (falta de um pai).

\section{Entrevista com Dona Célia}

Contexto:

A Dona Célia recebeu muito bem a pesquisadora, que explicou que iria conversar sobre a escola de Jéssica. Ela se propôs a responder de imediato dizendo que 
apesar de Jéssica mão ser sua neta biológica, sendo filha da mulher de seu filho, é ela quem faz seu acompanhamento escolar. Ela participa das reuniões, conhece as professoras e o ambiente escolar.

Dona Célia mora no centro do jardim Pitangueiras, numa casa simples por fora, como as outras do bairro. Por dentro, ela é muito arrumada, com um piso claro e pintada. Na sala onde foi feita a entrevista havia uma televisão e um videocassete na estante. Ao lado, havia uma copa mobiliada, com uma geladeira grande. Toda a casa estava cheia de plantas, sendo muito bem cuidada.

Dona Célia se mostrou o tempo todo muito solícita, parecendo gostar de participar, dar sua opinião e poder falar.

Análise geral:

Dona Célia revelou uma postura predominantemente submissa diante da escola, apontando claramente que considera o saber da escola e dos professores muito superior ao seu. Mostrou-se envergonhada por não ter muito estudo e relatou que sempre recebeu as reclamações da escola sobre os filhos e netos como algo que a envergonhava muito.

Ela defendeu as regras da escola, a ordem e as posturas autoritárias. Em alguns momentos se contradisse e colocou que o modo mais amistoso dos professores é melhor que o modo autoritário.

Ela afirmava, no entanto que os professores têm sempre razão e que a família deve manter a qualquer custo os filhos respeitosos e educados, em casa e na escola.

\section{Entrevista com Rose}

Contexto:

Assim que a pesquisadora chegou na casa, a Rose ficou meio ressabiada, mas ao ser-lhe apresentada a pesquisa, ela a chamou para entrar, dizendo que poderia responder naquele mesmo momento. Ela parecia meio tímida no início, não conseguindo olhar muito para a entrevistadora. Mas na medida em que a conversa foi fluindo ela foi se soltando, terminando por falar bastante, se sentindo até bem à vontade. Quando o gravador foi desligado, ela foi pegar fotos do bairro para mostrar para a pesquisadora. Mostrou, também, fotos de sua casa e dos filhos. A pesquisadora ficou com ela, após terminada a entrevista, mais ou menos uma hora. Ela conversava, mostrava as fotos e contava sobre a evolução do bairro. Mostrou também sua casa, seu quintal e a vista da 
sua varanda. Antes que a pesquisadora fosse embora ela ofereceu café e convidou-a para voltar outras vezes.

A casa fica no Jardim Pitangueiras, numa área de nível sócio-econômico mais elevado. É grande e bem acabada, tem uma sala, copa, cozinha, dois quartos, dois banheiros, quintal e uma varanda grande. Tudo muito bem montado, ambientes amplos e bem mobiliados. Na garagem tinha um carro (Brasília).

Ela contou a história do bairro, pois quando se mudou não havia nem água nem luz, tendo acompanhando o crescimento da comunidade ali. Ela enfatizou muito o quanto é participativa e o quanto colaborou para obter melhorias na sua própria vida e no bairro.

Análise geral:

Salta aos olhos, no decorrer da entrevista, uma grande exaltação do que a família conseguiu por meio de luta: casa melhor, bairro melhor, escola melhor. O bom desempenho dos filhos na escola também é visto como fruto do empenho dos pais. Assim, o discurso hegemônico está presente de forma predominante nos seus relatos (as falhas são atribuídas ou ao aluno ou à família). No final da entrevista, ocorreu uma leve alusão a alguns conflitos vividos ou reconhecidos por ela:

- Ensino moderno versus ensino antigo e competência dos pais para ensinarem os filhos.

- Jogo de culpabilização às falhas ocorridas na escolarização dos filhos: culpa do governo ou do professor?

Mas ao concluir, a Rose ressaltou, ainda, o problema do não empenho e acompanhamento das famílias com relação à escolarização dos filhos. A entrevista foi marcada, assim, pela quase ausência de um pensamento crítico. As queixas leves se direcionaram ao governo e aos pais "descomprometidos".

\section{Entrevista com Elza}

\section{Contexto:}

A pesquisadora foi uma primeira vez na casa da Elza, que a atendeu muito bem, servindo um café e logo falando que tinha muita coisa ruim para falar da escola. Atendeu a pesquisadora como se já a conhecesse há muito tempo, chamando-a para entrar antes de saber ao que se referia a visita. Ela conversou um pouco e colocou que 
não poderia fazer a entrevista naquela tarde, marcando um outro encontro para daí a dois dias. Antes que a pesquisadora fosse embora, ela ainda falou que tinha muitas queixas para fazer do bairro. Contou de um "tarado" que ronda por ali e que já tentou pegar a filha (sic). Ela foi o tempo todo muito simpática, contou da sua vida na roça, falou dos três enteados e das duas filhas. Falou também que eles estavam passando por problemas de falta de comida em casa, já que o marido estava desempregado. Ela mostrou, ainda as costuras que faz para fora para complementar a renda da casa.

A pesquisadora voltou na casa três vezes, em dias diferentes, até que pudesse ser feita a entrevista. A casa é muito simples, no centro do Jardim Pitangueiras, na sua parte mais pobre. Em uma das vezes que a pesquisadora esteve lá, a casa estava com cheiro de carniça porque o mocotó que eles limpam estava na porta da casa há alguns dias, sem que a pessoa responsável viesse buscar.

A entrevista foi realizada na varanda e, enquanto conversava com a pesquisadora, ela ia costurando. Sua Filha de seis meses acordou no início da entrevista e a pesquisadora ficou com ela no colo para poder conversar com a mãe. O choro da filha interrompeu várias vezes a conversa, pois ela estava com piolhos. A pesquisadora ficou cerca de três horas na casa até que conseguisse perguntar tudo que havia planejado. A entrevista foi muito entremeada de temas e problemas pessoais: dificuldade financeira e relacional, sendo o seu discurso predominantemente emocional.

Análise geral:

A Elza se mostrou muito à vontade desde o inicio da entrevista, dando a impressão de estar falando livremente sobre o assunto, sem medo de fazer críticas à escola. Seu relato apontou que as situações positivas vividas na escola foram com algumas professoras mais afetivas e carinhosas. No mais, seu discurso trouxe muitas críticas tanto quanto ao espaço físico da escola, quanto ao desrespeito vivido pela filha lá.

\section{Entrevista com Dona Rita}

Contexto:

Quando a pesquisadora chegou na casa, a filha de Dona Rita a atendeu e foi chamar a mãe, que prontamente se propôs a participar da pesquisa, convidando a 
pesquisadora para entrar na casa (antes mesmo que fosse dito exatamente do que se tratava a entrevista). A entrevista foi feita naquele mesmo momento, na sala da casa, com a netinha brincando por perto e dois filhos sentados ali também. A entrevista foi interrompida várias vezes para que a entrevistada cuidasse da neta. Quando foi encerrado o assunto da escola, a entrevistada mudou, se soltou, se mostrou engraçada, falando dos seus medos e de muitas coisas mais que fazem parte da sua vida.

A casa fica na parte mais simples do Jardim Esmeralda, não está terminada, tendo montes de areia na porta. O piso ao redor da casa é de terra, com alguns móveis neste local (descobertos)

Análise geral:

Ficou clara a visão da mãe de que a escola tem sempre razão, apoiando a rigidez das suas ações. No seu ponto de vista, sempre que acontece algum problema na escola, a culpa é do aluno. As dificuldades vividas lá advêm de seus próprios problemas e dos problemas familiares. Assim, a escola tem sempre o direito de cobrar.

No entanto, no decorrer da entrevista, apareceu uma certa ambigüidade quando ela se defendeu das cobranças a ela feitas, colocando que não tem tempo de acompanhar todos os filhos na escola. Por outro lado, esse fato não parece ser assumido de forma que a isente de críticas. Pelo contrário, ela colocou que se os filhos derem problema na escola, seu desejo é tirá-los de lá. Ela atribuiu as dificuldades de aprendizagem dos filhos ao fator genético, uma vez que também não se deu bem na escola.

Concluindo, durante a maior parte da entrevista, a Dona Rita repetiu o discurso hegemônico, se justificando por não poder cumpri-lo. Nas entrelinhas, ela deflagrou algumas dificuldades da escola, mas sem críticas, buscando um jeito positivo de contálas, ou seja, se colocando emocionalmente fora da situação ("aquilo é o certo").

Assim, a ideologia da exclusão está muito presente no seu discurso: o ensino hoje é difícil, ela não conseguiria, mas a pessoa inteligente supera tudo (sic). Às vezes ela se contradiz quando fala da própria situação, mas fica clara a tentativa de adaptar-se ao que é considerado por ela "evoluído". 


\section{Entrevista com Roberta}

Contexto:

A pesquisadora foi na casa uma primeira vez e marcou a entrevista com a Roberta que, desde o início, a recebeu com um sorriso, atendendo-a muito bem. A pesquisadora chegou no horário combinado, tendo observado a chegada da mãe em casa carregando duas crianças no colo.

A casa fica numa baixada do Jardim Bela Vista, em um local que parece uma favela. É uma casa de três cômodos, não acabada, sem piso e com grama na frente. Na fachada faltam vidros nas janelas, que estão cobertas com pano.

A entrevista foi feita na sala, com as crianças brincando ao redor. A Roberta começou contando sua história, mostrando muito sofrimento. Atualmente ela tem que sustentar seis crianças e tem dificuldades em conseguir um trabalho onde possa conciliar a casa e o serviço.

Para ir trabalhar, ela já deixou os filhos menores com a filha de dez anos e essa quebrou o bracinho do bebê. A mãe contou o sofrimento que é pedir isso para a filha, mas quando falta comida, não há outro jeito. Ela se emocionou durante a entrevista, segurando algumas vezes para não chorar. No final, agradeceu a entrevistadora e disse que às vezes uma palavra vale mais do que ajuda financeira. (sic) Disse que se sentiu bem por ter podido desabafar.

Parece que ela tinha pouco a dizer sobre a escola, até porque não está freqüentando-a. Além disso, a escola mostrou ser o menor dos seus problemas.

Análise geral:

Essa entrevista tem algumas particularidades: o universo escolar é pouco conhecido pela mãe e suas respostas quanto a esse tema específico são genéricas. Ela tende a se culpar e culpar os filhos pelas dificuldades escolares. Não atribui responsabilidade à escola. No decorrer da entrevista ela relatou episódios de agressão vividos na escola, mas não mostrou ter uma visão crítica sobre isso.

Após responder vagamente às perguntas temáticas, ela voltava às suas dificuldades pessoais, mostrando dificuldade em lidar com a escola e com os filhos. Ela ressaltou que, muitas vezes, não sabe como agir, pois foi criada na "roça", de uma maneira muito diferente de hoje. A entrevista é rica em relatos das dificuldades da infância, do casamento e de conseguir trabalho. As condições de sobrevivência da 
família são precárias e a vida familiar gira em tomo desse tema, o que frequentemente gera um conflito entre trabalho e escola.

\section{Entrevista com Inês}

Contexto:

A entrevistadora chegou na casa dez minutos mais cedo do que o horário combinado e ficou esperando do lado de fora. Logo a mãe chegou, não se dirigindo diretamente à pesquisadora, virando o rosto e entrando rapidamente na casa. A pesquisadora percebeu, então, que ala tinha grandes manchas no rosto e provavelmente estava constrangida. A pesquisadora entrou na casa atrás dela, sentando-se na sala, que estava bem escura. No corredor, a pesquisadora passou por um senhor, o qual não respondeu ao seu cumprimento. As filhas mais velhas, muito tímidas, estavam todas sentadas na sala e ouviram a entrevista, ajudando às vezes a mãe com detalhes que ela não sabia. As filhas mais novas conversaram mais tranquilamente, enquanto as mais velhas foram mais frias.

A casa é relativamente grande, na divisa do Jardim Pitangueiras com o Jardim Esmeralda. Logo na entrada tem uma copa e uma cozinha bem equipada; na sala tem dois sofás e uma estante com televisão, cheia de plantas. Tudo muito bem cuidado.

A entrevista foi feita praticamente no escuro e a entrevistadora teve dificuldade em fazer anotações e verificar se o gravador estava funcionando. No decorrer da entrevista, a Inês foi se soltando e passou aquela impressão inicial de estranhamento.

Quando inquirida sobre a família, ela começou a falar da escola, talvez desejando terminar logo a entrevista. A pesquisadora explicou, então, que alguns dados sobre a família faziam parte também da entrevista. Então, ela foi bem colaborativa e sua apreensão foi diminuindo. Provavelmente ela tenha se sentido constrangida porque é praticamente analfabeta (sua origem é rural, o que fica claro no seu jeito de ser e de falar) e porque não tem participado muito da vida escolar dos filhos. Além disso, ela também tinha um pouco de dificuldades para falar, porque não tinha os dentes da arcada superior. Disse que tem trabalhado muito e ainda cuida da mãe que está numa cadeira de rodas.

Com relação ao tema da escola, ela respondia na maioria das vezes genericamente: a escola é boa, o professor é bom. A entrevistadora perguntava, então, mas como que é bom, tentando esmiuçar mais o assunto, tentando não constrangê-la. 
No final da entrevista ela estava bem à vontade, conversando livremente e até levou a pesquisadora até a porta, sem parecer se importar mais com a própria aparência.

Análise geral:

A Inês iniciou seu relato apontando suas dificuldades em acompanhar os filhos na escola, tentando se justificar, mostrando que faz o que pode. Antes que fosse perguntando qualquer coisa sobre a escola, ela já ia falando que era boa e logo se justificava dizendo que elas (da escola) não têm o que reclamar dela (mãe). Fica clara, assim, sua postura defensiva.

Ela identificou, no entanto, no decorrer da entrevista, professoras boas e ruins e, apesar de ter vontade de trocar de classe quando a professora é ruim, ela afirmou que diz para a filha não dar importância a isso. Ressaltou, ainda, que não pode dizer à filha que a professora está errada, deixando clara a forma como ensina a ela uma forma submissa de se relacionar. Parece que seu relato traz o seguinte discurso implícito: os professores e a escola não devem ser questionados. Em alguns momentos ela esboçou leves críticas, mas colocava a solução sempre nela mesma: corrigir a situação em casa.

Assim, ela mostrou dificuldade em fazer "reclamações" na escola e pareceu não dar importância àquilo que discorda. De maneira geral, sua fala foi no sentido de exaltar a escola e se justificar pelas suas "possíveis falhas".

\section{Entrevista com Carolina}

Contexto:

A pesquisadora havia marcado o horário da entrevista previamente e, quando chegou à casa, a Carolina a atendeu muito bem. No entanto, quando foi pedida a permissão para gravar a entrevista, ela ficou ressabiada. A conversa sobre esse assunto se estendeu por um bom tempo antes que ela permitisse a gravação. Ainda assim, ela pareceu ficar tensa quando o gravador foi ligado, tendo um pouco de dificuldade para falar. Ela ficou muito desconfiada, também, ao ler o esclarecimento do sujeito da pesquisa, fazendo várias leituras, até que se sentisse segura para assiná-lo.

No entanto, durante a conversa ela se soltou e a entrevista durou cerca de duas horas, tendo sido realizada na sala. A casa é muito arrumada, cheia de plantas, com 
móveis novos, televisão grande, telefone e quadros na parede. Fica na divisa do jardim Pitangueiras e jardim Esmeralda, num local de casas grandes.

Quando acabou a entrevista ela agradeceu muito, dizendo que gostou de conversar. Falou ainda que a pesquisadora era uma pessoa de "tirar proveito" e, já que estava ali, ela queria "tirar esse proveito" (sic). Como a pesquisadora não compreendeu bem do que se tratava, ela esclareceu que "queria ajuda em alguns problemas que estava vivendo, já que a pesquisadora era psicóloga". (sic) Ela pediu, ainda, que a pesquisadora marcasse uma conversa com o filho para aconselhá-lo. A pesquisadora, então, foi ouvindo-a um pouco e fechando a conversa, para não misturar os papéis. Antes de sair, ela ofereceu suco e a convidou para voltar na casa. Quando a pesquisadora disse que qualquer dia voltaria, ela pediu que prometesse. A pesquisadora disse, então, que voltaria para devolver a fita da entrevista, depois que fosse feita sua transcrição (ela havia pedido).

Quando a pesquisadora ia saindo, ela pediu uma carona para ir à casa de uma amiga (mãe de uma outra aluna da escola). Chegando lá, ela pediu para que a pesquisadora aguardasse um pouco, enquanto contava sobre a pesquisa para a amiga, que se interessou em ser entrevistada.

Análise geral:

A Carolina demorou um pouco para se soltar, parecendo que tinha muitas críticas a fazer sobre a escola, mas estava com medo de fazê-lo e desagradar à direção. Seu discurso começou com elogios e terminou com críticas.

Ela enfatizou mais os aspectos emocionais do que materiais da escola, colocando a importância de práticas relacionais baseadas no respeito e amor. Ela sugeriu, ainda, ações concretas para a melhoria das condições da escola.

\section{Entrevista com Cibele}

Contexto:

A Cibele atendeu a pesquisadora no horário combinado e convidou-a para se sentar na cozinha, onde seria feita a entrevista. O contato foi fácil, ela foi colaborativa e ainda disse, no final, que a conversa tinha servido como desabafo. 
Sua casa é bem grande, fica na parte nobre do Jardim Esmeralda, é toda murada, com portões de ferro. Na frente tem uma garagem ampla, cheia de plantas e dois carros. A cozinha onde aconteceu a entrevista estava equipada com eletrodomésticos de última geração. Na sala havia um computador. Durante a entrevista, os filhos que estavam em casa entravam e saíam da cozinha, mas sem interromper a conversa.

Análise geral:

A Cibele revelou um discurso crítico com relação à escola, considerada por ela um sistema muito rígido de regras e normas. Em alguns momentos ela se mostrou confusa, voltando atrás no que havia dito, pedindo para a pesquisadora riscar sua fala. Isso talvez tenha ocorrido porque o que ela considerava como idealmente "correto", não parecia bom para a sua filha, quando ela refletia melhor. Parecia que na medida que ela ia falando, também tomava consciência de novos aspectos.

Ela ressaltou a boa situação financeira da família, afirmando ser diferente das outras famílias da escola, tendo uma outra cultura e não querendo se envolver com os outros. No decorrer da entrevista ela foi mudando esse discurso, falando de algumas dificuldades, tanto financeiras, como de ter amizades.

Esse movimento pode estar indicando que ela foi aos poucos se deixando mostrar, na medida que a relação com a entrevistadora foi se tornando mais confiável. $\mathrm{O}$ tom auto-afirmativo do início da entrevista foi, assim, desaparecendo.

A entrevista foi rica em relatos pessoais, história da infância, modo de funcionamento familiar, metas, crenças e, também, sobre vivências na escola.

\section{Entrevista com Fabiana}

Contexto:

Quando a pesquisadora chegou à casa da Fabiana, seu filho foi chamá-la e pediu que entrasse: "Vai entrando, vai entrando". Sem saber bem por onde entrar, a pesquisadora chegou no fundo da casa, num quintal onde havia uma edícula e lá estava a mãe cozinhando.

Como ela estava ocupada, a pesquisadora disse que voltaria outra hora, mas ela falou: "Não, pode ir entrevistando. Para mim é melhor se você puder ir me entrevistando enquanto eu faço as coisas aqui" (sic). 
Então a conversa aconteceu ali no fogão mesmo, apesar do barulho da panela de pressão atrapalhar um pouco a gravação. Depois, ela convidou a pesquisadora para se sentar e terminar a entrevista. Ali junto, um homem estava assistindo jogo de futebol e, segundo a Fabiana, ele aluga o quarto dos fundos. A entrevista foi interrompida uma vez para ela atender o telefone.

Ela foi se soltando no decorrer da entrevista, mas no início estava fechada, não querendo falar muito. No final, estava tão à vontade que disse que participaria do grupo, apesar de ter dito anteriormente que não teria tempo para isso.

A casa fica no Jardim Esmeralda, em um local onde as casas são de todos os tipos, das mais simples às mais requintadas. Ela é grande, tem cozinha modulada, bem equipada. A Fabiana tem um carro novo, que estava na garagem. Ela reclamou de dificuldades financeiras, justificando que tem que sustentar o filho sozinha.

O contato foi leve e a entrevista rápida, porque em alguns momentos ela parecia afobada, mostrando um pouco de pressa.

\section{Análise geral:}

A Fabiana foi um pouco resistente no início da entrevista, só respondendo às questões da entrevistadora, sem dar continuidade aos assuntos. Principalmente na parte da contextualização, quando o assunto era a família, ela mostrou-se reticente, perguntando se precisaria mesmo gravar. Ela mostrou-se um pouco constrangida com isso.

No entanto, aos poucos foi se soltando e no final da entrevista já estava bem mais à vontade. Ela não citou situações específicas que ocorreram na escola, uma vez que está longe do cotidiano escolar, segundo ela mesma. Falou, então, das impressões que tem ao acompanhar as tarefas do filho e ao observar a relação que ele possui com os vários agentes escolares.

\section{Entrevista com Jerusa}

Contexto:

A Jerusa mora no bairro Jardim das Flores, que é um bairro de classe média / média-baixa. Vale notar que são poucas as crianças da escola provenientes desse bairro. 
A casa não está pintada por fora, mas é grande e ajeitada por dentro. A cozinha e a lavanderia são bem equipadas e ainda tem uma edícula no fundo.

Ela recebeu bem a pesquisadora, chamando-a logo para entrar, dizendo que poderia fazer a entrevista naquele momento mesmo. A conversa aconteceu na varanda, um lugar fresco e agradável. No início, ela pareceu tensa, respondendo às questões com poucas palavras e a entrevista parecia não fluir. No final ela se soltou e, mais ainda, quando o gravador foi desligado. Nesse momento ela falou da filha, dizendo que era rebelde, perguntando o que deveria fazer para lidar com ela.

Quando convidada a participar do grupo, disse convicta que iria, pedindo que a pesquisadora ligasse para avisá-la sobre a data. No final agradeceu, dizendo que foi bom conversar.

Análise geral:

A Jerusa respondeu brevemente às questões relativas à escola e aos professores, revelando uma postura acrítica e submissa diante desses temas. Ela mostrou idealizar a escola, atribuindo toda dificuldade à criança. Elogiou o ensino e apontou que hoje a escola é melhor que antes, uma vez que as pessoas têm mais acesso a ela e, ainda, perto de casa.

\section{Entrevista com Mariana}

Contexto:

A Mariana é merendeira na escola e tem uma filha que estuda lá. Desde que foi iniciada a observação participante na escola, ela sempre se mostrou simpática e solícita, se oferecendo para participar da pesquisa. A entrevista foi realizada na cozinha da escola, local onde ela trabalha e onde a conversa poderia acontecer com mais privacidade.

Naquele dia, Mariana não estava muito bem, disse que estava sendo medicada por depressão e estava com vários sintomas. Durante a entrevista, bocejava muito, parecendo estar com dificuldades de memória. Ela explicou que o remédio não estava fazendo bem e que ela não concordava que o seu problema era depressão.

Quando o assunto era a escola e os professores, ela ficava totalmente travada, se soltando mais quando o tema era mais genérico, como a escolaridade. Nesse momento, ela pareceu conversar livremente e de maneira mais tranqüila. Depois de desligado o 
gravador, ela ainda ficou um bom tempo falando de sua doença, sendo seu tom, nesse momento, mais animado.

Conclui-se que, talvez por trabalhar na escola, tenha sido difícil para ela falar sobre o que observa ali. Quando o assunto era mais geral, ela falava de forma mais fluida.

Análise geral:

A Mariana apresenta um discurso onde fica clara uma postura submissa e acrítica diante dos fatos que ocorrem na escola. Ao mesmo tempo, essa característica foi por ela criticada e apontada como sendo comum em pessoas que não estudaram.

Quando, no decorrer da conversa, aparecia alguma contradição, ela se negava a refletir e responder, fechando o assunto. Foi, portanto, uma entrevista pobre em exemplos e vivências, apesar da Mariana estar todos os dias na escola. Ela não criticou quase nada, mas também não elogiou muito. Mostrou-se mais preocupada com o desempenho das filhas do que com a avaliação da escola e dos professores.

\section{Entrevista com Gisele}

Contexto:

A entrevista durou três horas e meia e foi realizada na casa da Gisele, que é bem perto da escola, situada no Jardim Esmeralda, onde o predomínio é de casas de padrão médio. As condições materiais da família são boas, eles possuem dois carros e têm um quintal grande na frente da casa.

Desde o início da entrevista ela foi bem tranqüila, já começou falando da família, e se abriu bastante. No final, ela também agradeceu a oportunidade de estar conversando sobre esses assuntos e se dispôs a participar do grupo.

No meio da entrevista a Gisele, que é amiga da escola, teve que sair e ficar com as crianças na hora do recreio. A pesquisadora foi junto e observou suas atividades. Em seguida, a entrevista foi retomada.

Ela falou muito, parecendo ter um conhecimento amplo da escola. Por ser "amiga da escola", tem contato com os alunos, professores, direção e funcionários, sendo uma informante privilegiada. 
Análise geral:

A Gisele foi muito solícita durante a entrevista, contando detalhadamente várias experiências que teve na escola. Grande parte da entrevista girou em torno da sua função como "amiga da escola". Ela elogiou muito a diretora e algumas professoras e, as poucas críticas que fez foram seguidas de uma justificativa. Ou então ela destacava, em seguida, que a escola era muito boa.

Seu discurso parece ser o discurso hegemônico da escola, mas ao contar as experiências, algumas contradições apareceram. No entanto, ela não se deteve nessas questões e voltou a elogiar a escola.

\section{Entrevista com Silvia}

Contexto:

Antes de iniciar a entrevista, a Silvia estava cansada, com olhos baixos. Era fim de tarde, depois do horário de trabalho. Ela convidou a pesquisadora para se sentar na sala de sua casa e, quando iniciada a entrevista, respondia tudo com frases curtas. Parecia que não queria muito se abrir, principalmente com relação às questões familiares.

A casa fica na parte mais pobre do Jardim Pitangueiras, sendo muito simples, sem forro, sem vidros e sem pintura. O filho da Silvia disse que a casa está caindo.

Assim que o gravador foi desligado, após a entrevista, ela começou a desabafar. Contou um pouco sobre as dificuldades do trabalho e o quanto vinha sofrendo com o marido, que bate nela. Por fim, contou que sua mãe se suicidou quando ela tinha sete anos. Sua mãe e seu pai eram alcoólatras. Ela e as irmãs foram criadas praticamente sozinhas (SIC). Ela falou, ainda, que às vezes pensa em se matar, em pular da ponte. Mas completou que não vai fazer isso, que ainda tem esperança.

Quando convidada a participar do grupo ela disse: "Ah, eu quero ir sim, quero ir pra espairecer". A pesquisadora ficou de ligar para confirmar a data e, antes que fosse embora, ela agradeceu e disse que estava muito aliviada, que a conversa a havia ajudado.

Análise geral: 
A Silvia se dispôs a conversar, respondendo as perguntas de maneira solícita, mas breve. Mostrou-se muito mais preocupada com questões do trabalho e sobrevivência do que com a escola dos filhos, relatando várias situações de sofrimento pelas quais passa.

Com relação à escola, ela não pareceu ter uma postura reflexiva, mostrando apoiar incondicionalmente suas condutas e normas, ao mesmo tempo em que exige dos filhos uma total adaptação ao sistema escolar.

\section{Entrevista com Ilda}

Contexto:

A pesquisadora foi ao endereço que constava na ficha da escola e a família não morava mais lá, estando a avó da criança no local. Ela pediu, então o endereço novo, mas a avó não sabia, apontando para que lado era a casa. A pesquisadora foi, então, procurá-la, perguntando na vizinhança onde era a casa da Ilda.

Chegando lá, a mãe recebeu bem a pesquisadora, convidando-a para entrar. A pesquisadora disse que poderia voltar outro dia para fazer a entrevista, mas ela falou: "Não, o tempo que a gente tem para conversar eu acho bom conversar. Eu não estou costurando sapato hoje." (sic) A entrevista foi feita na sala com nove crianças e um cachorro ao redor. A pesquisadora ficou um pouco atordoada com o barulho, pois as crianças gritavam o tempo todo, sendo difícil escutar a mãe. A mãe, no entanto, pareceu não se incomodar, dando a impressão de estar muito acostumada com aquele tumulto. Foi solícita e simpática, mas cortava a entrevista o tempo todo para gritar com as crianças, e até bateu numa criança na frente da pesquisadora, mas logo voltou ao assunto, como se nada tivesse acontecido. A pesquisadora teve dificuldade em manter o fio da meada, pois os assuntos ficavam muito cortados e a gritaria era enorme, além do barulho de panela de pressão, tudo em um cômodo pequeno.

A casa fica no Jardim Bela Vista, o segundo bairro depois da escola, local com casas muito simples e inacabadas. A mãe falou que o bairro é tranqüilo, mas que para ir à escola tem que se passar pelo Jardim Pitangueiras, onde há "muitos bandidos"(sic). A casa é pequena, quase sem móveis, com cortinas separando os cômodos. Está muito estragada, sem pintura e sem vidros nas janelas. 
Análise geral:

A Ilda pareceu falar tranquilamente sobre o que pensava, não mostrando críticas com relação à escola, dando a impressão de uma certa distância dessa realidade. Os assuntos da família entremeavam a entrevista sempre (problemas que estavam vivendo) e, no início, a mãe já foi justificando o porquê de não acompanhar as filhas na escola, colocando a dificuldade em conseguir que elas não faltassem. Como os assuntos ficaram cortados, houve dificuldade em compreendê-los. O relato sobre a doença do pai voltava sempre (ele está com câncer). Quando inquirida sobre as professoras e a escola, a mãe normalmente respondia apontando as dificuldades das filhas e o que tenta fazer para remediá-las. Ela pareceu se defender freqüentemente, ressaltando o incentivo que dá ao estudo das filhas e às práticas educativas na família.

\section{Entrevista com Sandra}

\section{Contexto:}

A entrevista durou duas horas e meia e foi realizada na copa da casa. O contato com a Sandra foi feito no grupo, já que ela compareceu sem ter sido entrevistada, à convite de uma mãe participante. Sua casa fica nos fundos da casa de sua mãe, no Jardim Esmeralda. É uma casa relativamente grande, cheia de plantas e muito bem cuidada. Na cozinha havia uma geladeira, fogão, armário e uma mesa pequena. Tudo simples e arrumado. Por fora, a casa estava no reboco, sem pintura.

O filho da Sandra estava em casa assistindo televisão e, às vezes vinha até a cozinha, dava uma olhada e voltava. Logo no começo da entrevista, quando a pesquisadora começou a conversar sobre a vida pessoal, a Sandra pegou um álbum de fotografias e mostrou seu filho, ainda bebê. $\mathrm{O}$ gravador foi, então, desligado porque ela ficou um bom tempo apresentando sua família nas fotos. Ela mostrou, também, o marido falecido e se emocionou. Como a pesquisadora percebeu que ela estava mobilizada, não perguntou sobre sua história, deixando-a falar se quisesse. Ela não contou, suspirou e fechou o álbum. No peitoril da janela havia várias motos de brinquedo e, ao lado, uma foto do filho com o pai, em cima de sua moto. Sandra disse que o filho coleciona motos. 
Ao final, quando desligado o gravador, ela contou que tem trombose, vivendo várias dificuldades com o atendimento no posto de saúde: não consegue marcar horário e os médicos são muito grosseiros.

Análise geral:

A Sandra falou muito sobre a família de origem, sua relação com os irmãos e as dificuldades que viveu com a morte do marido e criação do filho sozinha. Falou também sobre as dificuldades que sente em trabalhar como operária em fábrica. Com relação à escola, mostrou-se muito satisfeita, fazendo vários elogios, principalmente à diretora. No seu ponto de vista, os problemas que lá acontecem são apenas casos isolados, não havendo dificuldades sérias. Sua postura foi, portanto, acrítica.

\section{Síntese dos resultados sobre a contextualização das famílias}

- 12 famílias tradicionais, 3 reconstituídas, 6 monoparentais.

- Em 15 famílias pelo menos um dos pais é proveniente de outras cidades, principalmente do sul de Minas Gerais.

- Escolaridade (do entrevistado e do cônjuge, se for o caso):

\begin{tabular}{cl}
\hline Número de Pais & Nível de Escolaridade \\
12 & Segundo Grau Completo \\
06 & Ensino Fundamental Completo \\
07 & Ensino Fundamental Incompleto (de $5^{\mathrm{a}}$ a $8^{\mathrm{a}}$ séries) \\
08 & Ensino Fundamental Incompleto (de $1^{\mathrm{a}} \mathrm{a} 4^{\mathrm{a}}$ séries) \\
03 & Semi-Analfabetos \\
\hline
\end{tabular}

- Ocupação profissional:

Pais

\begin{tabular}{c|c}
\hline Tipo de trabalho & Número de pais \\
\hline "não-braçal" & 6 \\
\hline "braçal" & 9 \\
\hline
\end{tabular}

Mães

\begin{tabular}{c|c}
\hline Tipo de trabalho & Número de mães \\
\hline Do lar & 5 \\
\hline $\begin{array}{c}\text { Remunerado sem sair de } \\
\text { casa }\end{array}$ & 6 \\
\hline Fora de casa & $\begin{array}{c}10 \text { (uma delas só } \\
\text { trabalha na época } \\
\text { do Natal) }\end{array}$ \\
\hline
\end{tabular}

- Alguns entrevistados relataram a ocorrência de sérias dificuldades sócioeconômicas, o que incide na vida escolar dos filhos (dificuldade de comprar material escolar e uniforme; necessidade de conciliar trabalho e escola). 
Postura dos entrevistados durante a entrevista individual

\begin{tabular}{|c|c|c|c|c|c|}
\hline Entrevistado & Postura na entrevista & $\begin{array}{l}\text { Escolari- } \\
\text { dade }\end{array}$ & $\begin{array}{l}\text { Ocupação } \\
\text { profissional }\end{array}$ & $\begin{array}{c}\text { Solicitado na } \\
\text { escola? }\end{array}$ & $\begin{array}{l}\text { Grau de } \\
\text { resposta }\end{array}$ \\
\hline Rafaela & Acrítica & $2^{\circ}$ grau & Vendedora & Sim & 5 \\
\hline Maria & Acrítica & $2^{\circ}$ grau & Func. Pública & Sim & 5 \\
\hline Mauro & Postura defensiva & $6^{\mathrm{a}}$ série & Fábrica & Sim & 5 \\
\hline Rose & Acrítica & $5^{\mathrm{a}}$ série & Do lar & Não & 5 \\
\hline Elza & Crítica & $6^{\mathrm{a}}$ série & Costureira & Não & 1 \\
\hline Dona Rita & Postura defensiva & $3^{\mathrm{a}}$ série & Do lar & Não & 2 \\
\hline Roberta & Postura defensiva & $3^{\mathrm{a}}$ série & Costura Sapato & Não & 1 \\
\hline Inês & Postura defensiva & $\begin{array}{c}\text { Semi- } \\
\text { analfabeta }\end{array}$ & Doméstica & Sim & 2 \\
\hline Carolina & Crítica & $1^{\circ}$ grau & Do lar & Não & 5 \\
\hline Ilda & Postura defensiva & $6^{\mathrm{a}}$ série & Costura Sapato & Sim & 2 \\
\hline Gisele & Acrítica & $8^{a}$ série & Do lar & Não & 5 \\
\hline Fabiana & Crítica & $3^{\circ} \mathrm{Col}$ & Vendedora & Sim & 2 \\
\hline Shirley & Postura defensiva & $4^{\mathrm{a}}$ série & Faz enxovais & Não & 5 \\
\hline Silvia & Postura defensiva & $6^{\mathrm{a}}$ série & Operária & Sim & 5 \\
\hline Sandra & Acrítica & $3^{\circ} \mathrm{Col}$ & Operária & Não & 5 \\
\hline Luzia & Acrítica & $3^{\circ} \mathrm{Col}$ & $\begin{array}{c}\text { Possui pequena } \\
\text { fábrica }\end{array}$ & Sim & 5 \\
\hline Valéria & Postura defensiva & $3^{\mathrm{a}}$ série & Costura Sapato & Não & 1 \\
\hline D. Célia & Postura defensiva & $4^{\mathrm{a}}$ série & Do lar & Sim & 2 \\
\hline Cibele & Crítica & $3^{\circ} \mathrm{Col}$ & Do lar & Sim & 5 \\
\hline Jerusa & Postura defensiva & $4^{\mathrm{a}}$ série & Costura Sapato & Não & 1 \\
\hline Mariana & Acrítica & $3^{\circ} \mathrm{Col}$ & Merendeira & Não & 5 \\
\hline
\end{tabular}

Quadro 4. Postura dos entrevistados no decorrer da entrevista individual

Parece haver uma relação entre baixa escolaridade e postura defensiva (justificativa pelas dificuldades ao invés de avaliar a escola). Já as mães com maior escolaridade ou se posicionaram ou de forma crítica ou acrílica.

Postura acrítica na entrevista individual: Gisele, Rafaela, Rose, Luzia, Mariana, Maria, Sandra

- Modelo tradicional de família, não havendo sérias dificuldades sócio-econômicas

- Participam da vida escolar dos filhos da forma como a escola exige 
- Parece ser somente essas mães que possuem algum acesso aos espaços decisórios dentro da escola, se é que eles realmente ocorrem.

- Reprodução do discurso hegemônico da escola, principalmente na entrevista individual.

- Colocam-se de forma submissa diante da escola. Seu desejo parece ser corresponder às expectativas da escola e não perder a posição de "incluídas". Culpabilização das famílias pelo insucesso escolar dos alunos.

- Essa mãe colaborativa e disponível parece ser o ideal valorizado pela escola, sendo esse modelo muitas vezes utilizado como pretexto para a crítica e talvez mesmo a exclusão daqueles que possuem um outro tipo de relação com a escola.

Postura crítica na entrevista individual: Carolina, Cibele, Elza e Fabiana

- Críticas enfáticas à escola na entrevista individual

- Medo de compartilhar as críticas, tendência à fuga da relação com a escola

Postura defensiva na entrevista individual: Roberta, Sr. Mauro, D. Célia, D. Rita, Ilda, Inês, Valéria, Jerusa, Shirley e Silvia

- Discurso repleto de respostas genéricas, apoio irrestrito à escola, ou justificativas pelo que não fazem pela escola e/ou filho

- Quando fizeram críticas, essas foram vacilantes.(apoio-crítica-apoio) 


\section{II - Resultados relativos às Entrevistas Individuais}

Os resultados relativos às entrevistas individuais foram agrupados em quatro grandes categorias: os professores vistos sob a perspectiva dos pais, a visão dos pais sobre a escola, o significado da escolaridade para os pais e o envolvimento dos pais com a vida escolar dos filhos.

\section{1 - Os professores vistos sob a perspectiva dos pais}

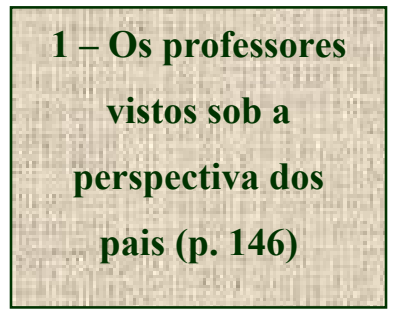

2- A visão dos pais sobre a Escola (p. 154)

3- O significado da escolaridade para os pais (p. 164)

\section{4- O envolvimento dos pais na vida escolar dos filhos}

(p. 170)
1.1 Vivências positivas com professoras (p. 147)

1.2 Vivências negativas comprofessoras (p. 148)

1.3 O Bom Professor na visão dos Pais (p. 150)

1.4 Críticas aos professores (p. 151)

1.5 Dificuldade dos pais em avaliarem os professores (p. 15

1.6 Percepção das dificuldades em ser professor (p. 152

Síntese dos resultados acerca da visão dos pais sobre os professores dos filhos (p. 152)

Figura 4 - Fluxograma relativo aos resultados das entrevistas individuais - Tópico 1 - Os Professores vistos sob a perspectiva dos pais 
Observa-se nos relatos dos pais, seis perspectivas através das quais eles traduziram sua visão acerca dos professores dos filhos. A primeira delas é relativa às vivências positivas dos entrevistados com os professores; a segunda traz as vivências negativas; a terceira abarca os atributos do bom professor na visão dos pais; a quarta enfoca algumas críticas dos pais aos professores; a quinta traz a dificuldade em avaliar os professores e a última traz os relatos em que os pais identificaram as dificuldades em ser professor.

\section{1 - Vivências positivas com professoras}

A maioria dos relatos a respeito dos professores foi relativa às vivências positivas que os pais tiveram com eles. Foram exaltadas, principalmente, as características positivas das professoras na relação com os alunos, tais como: ser carinhosa, atenciosa, calma, educada, buscar saber das dificuldades dos alunos, tratar os alunos de forma igualitária e ser como mãe para eles, ser paciente, interessada e preocupada com o desempenho do aluno. Além disso, alguns entrevistados apontaram como positivo o fato da professora repreender, cobrar e ser enérgica, desde que seja "com carinho", o que foi algumas vezes referido como "saber chamar a atenção do aluno"(sic). Alguns dos relatos que tratam desse tema podem ser observados a seguir:

\footnotetext{
"A professora que eu mais gostei ali foi a Mônica. Ela era carinhosa com os alunos, ela queria saber os problemas dos alunos.(...)A Mônica foi a mais amiga dos aluno, né." (Valéria)

"O que me admirou muito foi isso, ela tratava todo mundo igua.l" (Luzia)

"Tem a Marisa que teve paciência, sabe? Aquela professora de pegá na mão, e ajudá.(...) Achei que ela tem interesse em ajudá em ajudá os alunos." (Cibele)

"Então, eu acho assim, que ela foi como uma mãe pra ele (para o filho)." (Rafaela)

“A (professora) do primero ano(...) de tão calma que ela era pra conversá, eee, e aquele carinho, sabe?(...) Mais óia, e ela falava baxinho, com educação, explicava as coisa." (Elza)
}

Em menor número de ocorrência, apareceram os aspectos pedagógicos, ou específicos da função docente:

“Ela dava aquele tanto de lição. Eu gostava que ela dava lição.” (Jerusa) 
Em um relato apareceu ainda um outro aspecto, que é a atribuição de importância à maneira de ser da professora, sendo este um determinante para que os alunos gostem da escola:

"Ela consegue fazer os aluno mudá sem ofendê.(...) Meu filho tinha prazer de ir na escola por causa dela.(...) Eu acho que quando o aluno ama a professora, quando ela transmite amor, ele aprende. Ele dá atenção pra ela." (Carolina)

Alguns entrevistados trouxeram, também, características positivas das professoras na relação com os pais, sendo essas: a professora comunicava-se, conversava, era atenciosa, carinhosa e não "danava" (sic), como pode ser verificado nos relatos a seguir:

"Ah, você conversa com ela, ela tava sempre prestando atenção.(...) Ah, muito educada pra conversá, tava sempre incentivando a gente pra ajudá ele(o filho)." (Silvia)

"Ela me chamava, mas num danava comigo. Me falava que gostava dele (do filho), e como que eles ia fazer, e estudava um jeito lá dele ficar mais comportado." (Shirley)

\section{2 - Vivências negativas com professoras}

Os relatos sobre vivências negativas com professoras apontaram para aspectos da relação entre professores e alunos e nenhum trouxe aspectos da relação entre professores e pais.

Esses relatos apontaram situações criticadas pelas mães, onde houve constrangimento vivido pelos(as) filhos(as), provocado pela professora. A Rafaela criticou uma não consideração às diferenças religiosas dos alunos, a Carolina apontou uma situação em que o filho não pôde fazer prova por não ter levado dinheiro para tirar xerox e a Elza ressaltou o fato da professora ter colocado apelidos pejorativos na aluna, o que prejudicou seu rendimento escolar:

"Ele trata diferente o aluno porque as religiões tem várias diferenças. Umas não comemoram aniversário, como a nossa, essas coisa assim.(...) E a criança se sente constrangida perto dos outros." (Rafaela)

"O Daniel, meu filho, entre outros alunos da classe dele, fizeram, ti, teve, tiveram prova. E eu, porque eu num tinha recebido, ainda, num tinha dinheiro em mão, eu 
num levei, eu num mandei o dinheiro pra escola. A professora não deu a prova pro menino fazê. Entende?" (Carolina)

"Eu tenho reclamação da professora do ano passado. (...)Essa professora chamô a Mara até de pioienta.(...) Botô apelido na Mara o ano inteiro. Aquilo me, me deixô muito magoada.(...) A Mara, esse ano, tá péssima. Por causa do ano passado.(...) Ela chegava a falá que a minha, minha fia tava fedida. Ela chegô a falá. Mandô a Mara tomá banho antes de i pra escola.(...) Não, esse dia a Mara chegô aqui em casa chorano.." (Elza)

A Inês apontou, também, a falta de paciência da professora para com a filha, mostrando o desejo de tirá-la da escola, o que é visto como solução do problema:

“Então, essa professora desse ano... (...) Ela manda o, a outra criança apagá (a lousa). (...) Eu já tive até quereno i lá, tirá ela(a filha) da escola.(...) Porque ela tem um pouco de dificuldade, também.(...) Então, acho que a professora tem que tê um pouquinho de paciência com ela (dar o tempo para ela copiar a lição). " (Inês)

Somente dois relatos trouxeram questões pedagógicas como razão da vivência negativa com os professores. $\mathrm{O}$ primeiro aponta o fato da professora não olhar os cadernos dos alunos e o segundo traz uma reclamação sobre ausência de tarefa para casa:

"Ai a Marisa (professora) era mais lenta, né.(...) Deu uma atrapalhada. Uma atrapalhada boa mesmo. (...) Eu acho assim, sabe, eu acho... Ela não olhava os cadernos todos os dias." (Valéria)

"O ano passado, o que eu não gostei foi de não ter lição de casa. Eu não acho que isso é certo." (Sandra)

Por fim, houve um único relato criticando uma característica pessoal da professora, o fato dela ser brava e causar antipatia nos alunos:

"Mais esse ano eles não tão satisfeitos com a professora. Porque ela é muito brava.(...). Isso tudo vai criando antipatia, porque as criança tava acostumados com a outra que era muito boa." (Gisele) 


\section{3 - O Bom Professor na visão dos Pais}

Segundo os entrevistados, o bom professor precisa ter as seguintes características: ser carinhoso, educado e dedicado. Eles apontaram a importância do professor observar o aluno, considerando-o não somente no papel de aluno, mas em outros aspectos de sua vida, sendo acolhedor às suas dificuldades extra-escolares. A Carolina colocou, ainda, que essas características superam a técnica, quando a meta é ajudar o aluno a aprender. Alguns desses relatos podem ser verificados a seguir:

"Ou, porque eu acho que assim, até a criança tem poblema. A criança vai pra escola, cê num sabe se ela apanhô em casa, se ela comeu em casa, se ela tomô café da manhã, o que que aconteceu aqui em casa.(...) Primero tem que pensá na criança, pra depois pensá que ela, que ela tem aquela obrigação." (Elza)

"Eu acho que o amor, a dedicação é importante, faz com que mude o comportamento do aluno. Muda. Pode tê certeza. (...)Tem professor que ele consegue, com pouco, ééé, com pouca técnica, com carinho, ela consegue passá e fazê o aluno entendê. Ela consegue fazê a aluno voltá a atenção pra ela." (Carolina)

Já a Mariana e D. Célia ressaltaram os aspectos disciplinares da função docente, apontando que o professor deve dominar a sala e ensinar o aluno a se comportar:

"Eu acho que eles têm que dominar a sala, né? Porque às vezes tem professor que entra na sala, ele não domina a sala.(...) Se ele domina, ele consegue dá uma boa aula, né?" (Mariana)

"É o que as professora passa pros aluno, que eu acho que tem que sê o certo. Uma experiência não só de aprende a lê, a escrevê. Mais se comportá, a conversá, a entrá e saí dos lugar.(...) (A escola) é o lugar que cê vai aprendê a sê gente aqui fora. Eu acho que é o dever das professora." (D. Célia)

A Gisele e a Cibele apontaram que o professor deve, por um lado, ser carinhoso, atencioso e acolhedor com os alunos, mas por outro, deve ser exigente, impor respeito, manter a disciplina na classe e não tolerar bagunça. Esses aspectos podem ser exemplificados a seguir:

"Então eu acho assim, que tem um lado de ser professora que eu acho que ela tem que sê enérgica, ela tem que exigir, tá certinho. Mais eu acho que ela também tem que dar aquele carinho que precisa.(...) Elas têm que impor respeito, elas têm que manter a disciplina na classe." (Gisele) 


\section{4 - Críticas aos professores}

Alguns entrevistados fizeram críticas aos professores, sob vários aspectos: quanto ao seu desempenho, tais como: não corrigir os cadernos dos alunos devidamente, gritar na sala de aula, faltar muito; quanto ao seu envolvimento com o trabalho, criticando os professores que ensinam somente pelo salário; quanto ao tratamento dado aos alunos, aparecendo críticas ao tratamento diferenciado das crianças e à estigmatização de alunos devido a suas diferenças familiares. Uma mãe criticou, ainda, a frieza que observa na relação dos professores com os alunos. Alguns desses relatos podem ser verificados a seguir:

"Eu acho que os professores não, um erro, também, de não corrigir o caderno.(...) Eu acho que tá muito fria a relação do professor com o aluno. Tá muito distante " (Fabiana)

"Tem professor que grita demais, não resolve. (...) A criança vai aprender agressividade, vai só piorando." (Maria)

"Que tem professora que num ensina o aluno. Num é verdade? Eles qué ganhá dinheiro. Porque eu já estudei com uma professora assim. Por isso que eu tô falano." (Inês)

"Ah, sempre eu acho, assim, que elas(professoras) trata melhor quem tem dinheiro, tem status.(...) E, também, geralmente a professora abre um assunto assim, no meio dos aluno, por exemplo quando é assim, a criança é filho de pai separado. Fala: "Ah, cê tem problema porque você não tem formação de família. " A criança já vai crescer com isso na cabeça, vai ficar revoltada e fora que os outros alunos depois tira sarro nas crianças, fala, comenta." (Rafaela)

\section{5 - Dificuldade dos pais em avaliarem os professores}

Seis entrevistados mostraram uma postura submissa diante do saber da professora, julgando-o superior ao seu. Apontaram que a professora ensina a "experência certa"(sic) e que a educação dada na escola é melhor que a da família. Além disso, alguns desses pais atribuíram ao aluno toda a responsabilidade pela não aprendizagem escolar. Ao invés de falarem sobre os professores, como foi solicitado pela pesquisadora, eles justificaram as dificuldades dos filhos como sendo devidas a fatores intrapessoais e/ou familiares. Além disso, duas mães disseram não ter o que reclamar das professoras porque as filhas não têm dificuldades na escola. Estes 
entrevistados pareceram ter se julgado inaptos, pelo menos a princípio, para avaliar o trabalho da professora. Alguns desses relatos podem ser observados a seguir:

"Ah, não sei nada.(..) Olha, eu, com minhas filhas, eu não tenho muito que reclamar do professor, não, porque, minhas meninas não têm, assim, muita dificuldade." (Mariana)

"Pelo meno defeito dos professor eu não ligo.(...) Porque muitas veiz menina, os filho da gente escuta as professora, mais num escuta a gente.(...) Aqui em casa nóis ensina uma coisa. Lá elas vão dá a experiência certa. (...)Então eu acho a educação lá na escola melhor do que em casa." (D. Célia)

"O meu problema com as menina, é igual eu ti falei, é mais é problema, acho, de lerdeza delas.(...) Das professoras não tem nada pra reclamá, não.” (Ilda)

\section{6 - Percepção das dificuldades em ser professor}

Alguns entrevistados mostraram perceber as dificuldades que os professores têm enfrentado ao exercer sua profissão. Eles enfatizaram a pressão dos pais de alunos, falta de instrumentalização para lidar com a agressividade dos alunos, a má remuneração e a dificuldade de ensinar tantas crianças ao mesmo tempo, como pode ser observado a seguir:

\footnotetext{
"Porque tem criança que responde a professora, xinga, fala palavrão, né." (Rafaela)

"Porque eles ficam perdido.(...) Os meninos de hoje são rebelde mesmo. Mas os professores tinham que ter uma preparação, pra saber enfrentar.(...) Pra saber enfrentar esses problema das criança, essa agressividade que já vem." (Maria)

"É uma profissão que num... a pessoa estudou, estuda, estuda, eu quero ser professor.(...) Então tinha que ser mais bem remunerado, mais uma série de fatores." (Sr. Mauro)

"Trinta e oito cabeçinha, cada um de um jeito, não é fácil mesmo não." (Gisele)
}

\section{Síntese dos resultados acerca da visão dos pais sobre os professores dos filhos}

Esse bloco resultou da proposta do tema "professor do meu filho" feita pela pesquisadora, no momento da entrevista. O agrupamento de todas as falas relativas a esse tema, mesmo as que surgiram no decorrer da entrevista (quando o tema proposto já era outro), permitiu diferenciar três grandes estilos de relatos: aqueles que mostram um 
trabalho do sujeito ao se apropriar do tema, que são as narrativas; as falas em que o sujeito emite um julgamento sobre o tema, que são as avaliativas e, por fim, aquelas onde o entrevistado se defende do tema, justificando-se ou respondendo de forma genérica.

Quando incitados pela pesquisadora a falar sobre esse bloco temático, a maioria dos entrevistados adotou o caminho de construir uma narrativa para poder qualificar os professores. Vários deles relataram vivências onde o filho foi valorizado pela professora e utilizaram adjetivos positivos para caracterizá-la, tais como: carinhosa, calma, paciente, atenciosa, entre outros. Ainda trazendo uma conotação positiva, alguns entrevistados narraram situações que eles próprios viveram com as professoras dos filhos, ressaltando o fato delas conversarem e lhes darem atenção. Já outros entrevistados narraram situações onde o filho foi subjugado ou desqualificado pela professora, tendo, portanto, uma conotação negativa.

Os relatos mais avaliativos se distribuíram em duas categorias: como deve ser o bom professor e as críticas àqueles que não são considerados bons. $\mathrm{O}$ bom professor deve ser carinhoso, educado, dedicado, acolhedor às dificuldades extra-escolares dos alunos e, ao mesmo tempo exigente e afetivo. Ele deve, também, disciplinar a classe. Já as críticas aos professores foram relativas ao tratamento das crianças (discriminação, estigmatização, frieza e agressividade) e ao não envolvimento com o trabalho.

Por fim, as duas últimas categorias podem ser classificadas como sendo defensivas com relação ao tema proposto. Seis pais mostraram dificuldades em avaliar os professores, colocando seu saber como inferior ao saber do professor. Esses pais, ao invés de falarem sobre o professor, justificaram as dificuldades dos filhos, como se estivessem se defendendo de uma crítica. Nessa mesma direção, na categoria seguinte, cinco entrevistados, ao invés de avaliarem os professores, ressaltaram as dificuldades que esses enfrentam no contato com alunos e pais, além da má remuneração Esse fato parece estar reproduzindo a postura de submissão que esses pais assumem diante dos agentes escolares. É possível que a pesquisadora tenha sido vista por alguns deles como representante da escola e talvez esse fato explique a postura defensiva diante dos temas abordados na entrevista.

Grande parte dos pais, talvez por viverem situações de vulnerabilidade e instabilidade, esperam que o professor atue de forma afetiva e includente com os filhos, considerando suas dificuldades extra-escolares. Eles mostraram valorizar muito essa função do professor, priopritariamente à sua função pedagógica. 


\section{2 - A Visão dos Pais sobre a Escola}

1 - Os professores vistos sob a perspectiva dos pais

$$
\text { (p. 146) }
$$

2- A visão dos pais sobre a Escola (p. 154)
2.1 - Respostas genéricas e apoio irrestrito dos pais à escola

2.2 - A Visão dos pais sobre o aspecto físico da escola

2.3 - Visão dos pais sobre a função educacional e o ensino

2.4 - Progressão Continuada

2.5 - Reforço Escolar

2.6 - Visão dos Pais sobre as Normas da Escola

2.6.1 - Disciplina

2.6.2-Uniforme

Síntese dos resultados acerca da visão dos pais sobre a Escola dos filhos (p. 162)

3- O significado da escolaridade para os pais (p. 164)

4- O envolvimento dos pais na vida escolar dos filhos (p. 170)

Figura 5 - Fluxograma relativo aos resultados das entrevistas individuais: Tópico 2 - A visão dos pais sobre a Escola. 


\title{
2.1 - Respostas genéricas e apoio irrestrito dos pais à escola
}

Algumas entrevistadas responderam genericamente, quando inqueridas sobre a escola, dizendo que não possuem queixas e que a escola é boa, como pode ser exemplificado a seguir:

\footnotetext{
"Nessa escola eu não tenho o que reclamar.(...) A escola é boa, os professores. Agora lá por dentro assim, eu não tenho como falar porque eu não participo." (Roberta)

"Não, ichê! Às vezes eu penso, graças a Deus, nossa senhora, que tem as escola, pertinho aqui.(...) Eu falo, às vezes as pessoas ainda reclama, né? Eu não reclamo, de jeito nenhum. Eu acho que tá ótimo. Viche!" (Jerusa)
}

Outros pais mostraram uma postura de não questionamento, dando a entender que preferem pensar que não há problemas na escola a ter que fazer reclamações. Esse fato pode ser observado nos relatos a seguir:

\begin{abstract}
"Porque, eu, por exemplo, eu num gosto de recramá de ninguém. Eu sô uma mãe, assim, eu num gosto de recramação. Só que, às veiz, um fio, tem hora que chega e fala: "Mãe, aconteceu isso e isso." Às veiz, mesmo que eu senti magoada, eu entrego assim, pra Deus.(...) Então eu num tenho cumo num falá, assim, dos professor, não. Os professor dai são muito bom, mesmo. Mais são ótima, a escola.(rindo)" (Inês)
\end{abstract}

"Porque eu sou assim, sabe? Eu não fico em cima de escola procurando sabê se danou com o meu filho. Eu vou lá que é igual uma galinha choca, não. Porque se danou é porque tinha um motivo.(...) Então eu nunca fui na escola pra reclamá nada de nenhum filho meu. (...) Eu acho que eles tão lá trabalhando, não tão pra brincadeira, e eu não reclamo de nada. " (Dona Rita)

\section{2 - A Visão dos pais sobre o aspecto físico da escola}

Vários relatos trouxeram aspectos positivos da escola, apontando que ela é limpa, organizada, bonita, bem cuidada e tem uma boa merenda:

"É, a escola é muito bonitinha. (...)E arrumadinha. Não é aquela escola chique. Mas ela tem presença.(...) Ali na entrada você entra e já vê que é organizada, né.(...) Tem, é banheiro arrumado, água não falta, né. Acho que é o principal.(...) A alimentação também é boa." (Rafaela)

"A escola é limpa. E ainda eu tava comentando com a minha mãe hoje, que a única escola que eu acho mais limpa é essa." (Valéria) 
"A escola é boa, é, é uma escola limpa, é bem organizada.(..) Muito bem o, é, muito cuidada. Eles cuidam bem dos alunos, tem uma boa merenda." (Fabiana)

Algumas entrevistadas descreveram o que elas acham que ainda falta na escola, em termos de estrutura, uma biblioteca mais bem equipada, um laboratório, uma sala de informática e uma quadra de esportes:

\footnotetext{
"Bastante material pedagógico, uma biblioteca mais equipada.(...) Implantar uma sala tipo Ciências pros meninos." (Maria)
}

"Mas ainda tá faltando a quadra. Mas isso a gente sabe que é dificil conseguir, né. A diretora tá lutando pra isso. Mas não é fácil não." (Rafaela)

"Aquele lugar deles fazê ginástica, lá, de fazê a educação física, vai lá uma hora dessa, eles tá lá no meio daquela quadra torrano os pé, que é descalço que eles fazem, né? (...) E debaixo desse sol bruto." (Elza)

"Falta na escola uma sala de informática. Porque eu acho que, hoje, a escola, a criança da primeira série, ela já tem que começá a tê noções de informática, dentro da escola." (Fabiana)

E somente uma mãe fez críticas ao ambiente físico da escola, mais especificamente sobre o lugar da merenda e a falta de lugar para as crianças se sentarem e sobre a porta do banheiro:

"Lá, onde tem merenda, lá. É deste tamainzim.(...) Treis banco não dá.(..) Pras criança sentá na hora da merenda. Não tem lugar pra sentá.(...) Eu acho que aquela escola ali tá muito mal, mal repartida...Falta espaço.(...)Os banhero também tá um, uma narquia. A porta que fecha num abre. Se ocê passá a travinha cê fica preso lá dentro. Cê tem que passá ingatinhando por baixo da porta, arrastano." (Elza)

\section{3 - Visão dos pais sobre a função educacional e o ensino ministrado na escola}

Algumas mães colocaram que o ensino na escola é de boa qualidade, sendo suas justificativas para isso o fato dela passar lição para casa, o que significa que o "estudo é reforçado". Alguns exemplos desses relatos podem observados a seguir: 
"Ah, os ensino deles também é ótimo.(...)É, os cadernos, eles tão sempre passando lição, tão sempre, direto, todo dia tem lição pros alunos." (Silvia)

"O ensino eu acho bom também, de qualidade." (Luzia)

"Mais o ensino é bom sim, porque eu vejo os cadernos, as lição(...) E eu vejo que é bem dificil.(...) É bem reforçado o estudo daqui." (Sandra)

Outros pais apontaram que o ensino ministrado na escola pública atualmente é fraco, não possibilitando que os alunos ingressem em faculdades públicas:

"Pra mim o estudo de hoje é fraco. No meu posicionamento." (Sr. Mauro)

"Eu falo pra elas: "cêis tem que aprender em casa, é verdade, porque senão...(...) Não vai conseguir entrar em faculdade pública de jeito nenhum." (Maria)

O ensino atual é visto por uma mãe como difícil, mas as crianças inteligentes podem superar tudo, o que supõe a interiorização da ideologia do Dom. A Dona Rita deixou clara, também, uma visão negativa quanto a sua capacidade de aprendizagem:

"O método que eles ensina certo, que acha assim, muito apertado, muito agitado.(...) É muita coisa pra cabeça de uma criança, porque tem criança que não tem como, assim, destingui, assim, tudo, separá uma coisa da outra, um caderno pra isso, um caderno pra isso.(...) Tá certo que a pessoa, quando é inteligente, supera isso tudo e passa por cima. Eu memo, se fosse na época de hoje, se eu estudasse eu ia levá zero todo dia. Era bomba todo dia." (Dona Rita)

Algumas mães apontaram o desejo de que houvesse ensino religioso na escola:

"Aula de religião, ou, nem que se fosse, num fosse uma aula, fosse os próprios professores, que fizesse uma oração antes de, ou: "Vamo ficá todo mundo de pé" (...) Eu acho que no estudo tá faltano, tá faltano aí, mais, incentivá mais as criança, é na, religião, num é?" (Elza)

"Tê uma aula de religião, eu acho que num tem. Ó que bacana! Devia tê aula de religião, pouquinho, só um pouquinho. Falá um pouquinho de Deus." (Carolina)

Uma das entrevistadas mostrou uma visão positiva sobre o fato da escola ensinar higiene e limpeza para as crianças:

“...eles ensinam a criança a ter higiene, tanto com a limpeza, né. E tanto também com os cadernos, com a carteira e com tudo. É uma escola que eu vou te falá, tá de parabéns." (Rose)

Uma mãe ressaltou, ainda, a necessidade de que a escola desse uma orientação sexual para as crianças: 
"Quer dizê, acho que precisa conversá também... Parte sexual. Porque... A gente num procura sabê de nada disso dentro de casa. A gente qué sabê lá fora.(...) Eu acho que divia de tê uma pessoa especializada...(...) Pra conversá sobre esse tipo de coisa. Né? Uma professora, num sei se existe, uma pessoa assim..." (Elza)

\section{4 - Progressão Continuada}

Com relação à progressão continuada houve unanimidade dos pais que abordaram esse assunto, fazendo críticas a esse sistema. Os pais apontaram que as crianças estão saindo da escola sem aprender e que não há como culpar os professores, ou melhor, na realidade não há culpados claros com relação à ineficiência do sistema de ensino e, portanto, não há como protestar. Os prejudicados serão os próprios alunos quando se depararem com o mercado de trabalho. Alguns desses relatos podem ser observados a seguir:

"Eu acho que tem uma coisa muito errada nesse ensino mesmo. Sabe o que que é? As criança num bombá.(...) Porque, é tipo assim, ééé: "Eu estudano ou num estudano eu vô passá mesmo." (...) "Num tô nem aí. Pra quê eu vô estudá?"(...) Eu acho que, e tinha que voltá a tê bomba." (Elza)

"Por isso também que eles não esforçam, né, os alunos pra aprender.(...) Não entra numa faculdade boa, não entra de jeito nenhum.(...). E o mercado de trabalho tá aí, oh, exigindo e exigindo." (Maria)

"A criança não sabe lê, vai passando a criança, vai mudando ela de série. Mais e lá na frente?.(..) Porque depois vai falá: culpa de quem? Ninguém vai ser culpado. A mãe não vai ser culpada, o professor tampouco. Ah, só vai ficar a culpa ou só nos alunos ou só no governo." (Rose)

"Num aprende nada.(...) Quer dizer, ai num pode culpar, vamo supor, a escola, os professores.(...) O governo implantou ai esse método, acabou. Acabou, como se diz, jogou a bomba na mão dos professores e só faltou ele falá assim, se vira." (Sr. Mauro)

\section{5 - Reforço Escolar}

Com relação às aulas de reforço, uma mãe mostrou como elas são negociadas com a professora e a reprodução do discurso comumente ouvido na escola, de que os pais dos piores alunos não gostam que eles participem das aulas de reforço. Por outro lado, algumas entrevistadas se queixaram sobre o horário em que essas aulas acontecem, sobre a não negociação com os pais e dificuldades financeiras que impedem 
a presença da criança na escola fora do horário regular. Esses relatos podem ser observados a seguir:

"Reforço, às vezes ele nem precisava de reforço, ela falava: "Não, ele num tá muito bom, mas eu nem vou mandar." Aí eu falei: "Não, cê pode mandar, se tiver vaga cê pode." Porque tem mãe que não gosta que o filho vai no reforço.(...) Tem criança que tá ruim e os pais não manda." (Rafaela)

"Esse mato aí, ó, esse mato na porta da escola. Igual a Mara, tá de reforço. Sabe que hora ela vai saí de lá? 10 pras 7 da noite. Cê acha que eu posso dexá uma menina de 9 pra 10 ano vim sozinha? Passá perto daquele matagal?(...)Até estupradô tem aí, tarado, sem vergonha, tudo quanto é tipo de gente. Tem ai nesse pedaço.” (Elza)

"É ela ir no reforço. Mas eu não ia deixar não, sabe. Ah não eu não vou deixar.(...) Porque o horário vai ser da 17:30 às 19:00h.(..)Vai ficar direto. Vai ter uns dez minutinhos prá comer.(...) E a gente que é pobre não tem toda vez um dinheiro prá mandar lanche, porque quando nóis tem, nóis dá.(...) Elas explicou o porque do reforço. Só que não perguntô se a gente pode, se não pode.(...) Isso eu também acho que deveria perguntar, né." (Valéria)

\section{6 - Visão dos Pais sobre as Normas da Escola}

A visão sobre as normas da escola apareceu no relato dos pais, quando trataram dos assuntos disciplina e uniforme, como pode ser visto a seguir.

\subsection{1 - Disciplina}

Com relação à disciplina na escola, algumas mães a identificaram como positiva, enfatizando o fato da escola ensinar a ter respeito, ser bem vigiada, correta, bem organizada e com alunos bem comportados e educados, como pode ser visto nos relatos a seguir:

"Lá tem gatinho, sempre tem filhotinho. Se mexe com os gatos fica de castigo, sabe, assim. Tem respeito mesmo, eles com os animais" (Sandra)

"Que são, assim, toda escola tem aluno danado, mas ali, eles são bem, assim, se são danado, é depois do portão pra fora porque lá dentro é um respeito muito grande.(...) lá tem aquele, aquele vigia, lá, que fica olhando, lá, o caseiro, né? Fica supervisionando.(...) Então lá ninguém fuma.(...) Ali eles põe tudo no seu devido lugar.(...) Ali eles não dá espaço pras criança ficá subindo em muro, lá criança não leva bolinha, não leva figurinha, não, assim, não leva relógio, não leva celular, não leva nada que existe pra criança brincá, ali não entra. Não entra com canetinha, não entra com essas coisas que brinca, assim, de ficá fazendo narquia, ali não entra. Se vim na mão, já toma." (Dona Rita) 
"É uma escola boa, de você colocar os filhos e ficar mais sossegada.(...) O aluno que não tem um bom comportamento, elas chama a mãe, manda levar pra psicóloga, ou então manda colocar em outra escola." (Mariana)

"Assim, ordem. Ela impõe ordem.(...) Ela (diretora) impõe, ela qué e acabô. Ela exige.(..) Explicô com ordem o que ela queria, como é que era pros pais chegá em casa e falá pros filho comportar-se." (D. Célia)

Já a Carolina e a Ilda criticaram a rigidez com que são colocadas as normas e a falta de tolerância com quem se atrasa. A Carolina colocou, ainda, que às vezes a escola utiliza meios agressivos para conseguir seu cumprimento, citando uma situação vivida com a vice-diretora e criticando o fato da escola parecer um quartel militar:

"Então, você entendeu? Então fica assim, uma coisa meio esquisita. Teve, assim, umas 3 faltas dela, porque disse que ali na escola não deixa entrá mais... Passou de 5 minutos não entra." (Ilda)

"Tem escola que o aluno chega atrasado, ele passa na diretoria, explica o problema e entra. (...) E é, é, é aplausível. Ele gastô léguas pra i até a escola, chegô lá à pé, às veiz minininho que num tem condição financeira de tê um carro, de i de ônibus, vai a pé, tadinho! Então, tem que havê uma tolerância.(...) Outro dia eu vi a se, a vicediretora berrando no meio da rua: "Ei, cês são folgado, bábába'.......) Às vezes é verbal...(...) Às vezes pegava, pegá mal um braço, é uma agressão. Aquilo ali num é uma FEBEM. Num é uma, um, num é um quartel militar." (Carolina)

A Cibele também apontou que o sistema de disciplina da escola é muito rígido, porém necessário, visto o comportamento dos alunos:

\begin{abstract}
"Ah, eu acho que, que é muito rígido o sistema.(...) Tá certo que é isso que, eu tenho até medo de, de, digamos que a escola seja, assim, diferente por causa da, da gente achá ruim. Mas, e os alunos que num tem mais educação com os professores, né? Tem isso também. Porque eu já vi aluno mandando professor tomá banho...(...) Não, por esse lado eu vejo que a úncia solução aqui é essa.(...) Rédea curta." (Cibele)
\end{abstract}

Em um relato observou-se uma queixa à ineficiência da escola ao punir os alunos, como pode ser visto a seguir:

"Tem que mudar tudo, até as leis nesse negócio de punição.(...) Fala: "olha, terceira advertência é expulsão mesmo." Porque hoje não tem isso mais, né. Então eles faz o que faz e não tem punição nenhuma." (Maria) 
Por fim, uma das entrevistadas sugeriu de que maneira a disciplina deveria ser cobrada na escola, apontando que não se deve ofender o aluno, mas sim conversar com ele particularmente:

"Eu acho que um professor num precisa ofendê o aluno, chamá de burro, gritá, chamá a atenção. Eu acho que num precisa sê assim.(...) Eu acho que pode esperá um recreio, chamá num intervalo, o aluno, selecioná os alunos que tão dando trabalho, depois chamá no particular.(...) Eu acho que isso mostra pro aluno que tá respeitando" (Carolina)

\subsection{2 - Uniforme}

Alguns entrevistados apontaram sua concordância com relação às normas da escola relativas ao uniforme. A Ilda enfatizou a maleabilidade da escola quanto a esse assunto e os outros relatos elogiaram o fato da escola adotar o uniforme por ficar mais organizado, para se poder saber quem são os alunos da escola e para que o respeito seja mantido. Apesar de alguns relatos serem mais descritivos e não haver um posicionamento claro das mães quanto ao uniforme, ao se retomar o contexto, fica clara a postura de concordância com a escola.

"Ai eu fui conversá com a dona Sônia, pra aquela dali entrá sem uniforme. Porque as duas, essa entra, e a outra entra. Essa não entra. (....)(A diretora) deixou, autorizou. Mais eu conversei, expliquei pa ela direitinho." (Ilda)

" Ó, aqui cê sai à tarde, cê vê que os alunos sai tudo uniformizado, aí você percebe como é que é, né? (...) Outro dia eu tava sentada no portão de casa, à tarde, aí eu fiquei olhando. (...) Você vê a diferença, saem esses daqui, saem os dali (de uma outra escola)." (Mariana)

"Tem, tem que usar uniforme. (D: Você acha bom isso?) Eu acho. Eu acho bom porque o uniforme é escuro, lava duas vezes por semana, né. Se fosse um uniforme branco aí...." (Valéria)

"A Sônia (diretora) num aceita esse negócio de mini sainha, essas coisinha. Ela num aceita e num aceita memo. E ela tá certa.(...)Põe uma calça comprida.(...) Ela tá certa, ai é lugar de respeito e muito respeito." (D. Célia)

"Se não for com a camiseta é do portão pra fora." (Dona Rita)

Já as críticas com relação a esse tema foram relativas ao fato da escola ser muito exigente com os detalhes e mandar o aluno de volta para casa se o uniforme não estiver 
correto e, também, quanto ao preço do uniforme vendido na escola. Esses relatos podem ser verificados a seguir:

"É muito puxado. A gente paga aluguel. Então num tem como a gente entrá nesse assunto de roupa, tanto, igual elas qué. Eu acho que... É meio dificil, né? Eu acho que o aluno tem que i limpinho e não sujo, pa escola. Num é verdade? Tiveno com uma ropinha, mesmo disbotada, elas tá limpinha, eu acho que elas têm que aceitá.(...)E que, se manda o aluno voltá pra tráis, ele num vai estudá aquele dia, né?

(...) Chamaro, lá. Falaro que tava com short, ou roupa de outras cor.(...) Ela (filha) tava com um shortim jeans, um pouco meio desbotado, né? (...)E a dona Mirtes disse que pensô que era branco.(...) Então a gente tem que comprá uma tinta, vamo caçá um jeito de tingi porque eu num posso dá outro, agora, né?" (Inês)

"Eles pede pra fazê uniforme, o uniforme, e cobra aquilo que eles querem. Eu acho um absurdo.(...) Camiseta tá 11. Camiseta de escola? Eu num acho certo, não. Quantos pobres, eu, graças a Deus, dá pra comprá, mais... Reclamando mais pago. (Rindo) Mais, e os que num podem?" (Cibele)

\section{Síntese dos resultados acerca da visão dos pais sobre a escola dos filhos}

O segundo tema proposto pela pesquisadora, durante a entrevista, foi "a escola do meu filho". Os relatos organizados nessa categoria foram trazidos pelos pais em resposta a esse estímulo temático, mas também, quando mencionados por eles em outros momentos da entrevista.

Sete entrevistados responderam de forma defensiva ao tema, ou dando respostas genéricas, ou mostrando apoio irrestrito à escola, ou ainda afirmando uma atitude de não questionamento diante dessa realidade.

Muitos relatos foram avaliativos, acerca do aspecto físico da escola, do ensino ministrado e do sistema de progressão continuada. Houve consenso com relação ao fato da escola ser limpa, organizada, bonita e bem cuidada. As críticas foram relativas ao ambiente físico e recursos materiais.

Com relação ao ensino, quatro entrevistados o julgam de boa qualidade, três o julgam fraco e duas mães colocaram que é muito dí́cil. Vale ressaltar aqui o relato de uma dessas mães, que apesar de achar o ensino difícil, coloca que as crianças inteligentes podem superar tudo. Observa-se, nessa fala, a reprodução do discurso em que a razão do sucesso escolar está exclusivamente ligada aos dons individuais dos alunos. 
Houve, também, unanimidade entre os nove pais que falaram sobre a progressão continuada, tendo sido criticado esse sistema. Eles colocaram de forma negativa o fato de não haver repetência no ensino público.

Com relação ao Reforço escolar, uma das mães narrou como o negocia com a professora e reproduziu o discurso comumente ouvido na escola de que algumas mães não gostam que os filhos frequentem as aulas de reforço. Por outro lado, algumas mães justificaram o porque de não permitirem que as filhas voltem à escola para o reforço: dificuldades financeiras e impossibilidade de levar e buscar (já que o bairro é perigoso).

Os relatos dos entrevistados sobre as normas da escola foram agrupados em duas subcategorias: disciplina e uniforme.

Quanto à disciplina, alguns entrevistados narraram situações nas quais observase uma conotação positiva dada às atitudes da escola, tais como: vigiar, impor respeito e exigir que os alunos sejam bem comportados e educados. É importante ressaltar que uma dessas mães afirmou que a escola exclui as crianças que não se comportam bem e mostrou apoiar essa atitude.

Outras mães narraram situações onde pôde se observar uma conotação negativa sobre a maneira com que a escola exige disciplina. Foi criticada a intolerância e rigidez na cobrança das normas. Foi apontado, também, que a disciplina deveria ser cobrada na escola, sem que o aluno fosse ofendido.

Onze entrevistados falaram sobre o tema uniforme. Alguns deles narraram e descreveram situações que envolvem esse tema, dando uma conotação positiva ao fato da escola adotá-lo. Outros se justificaram com relação às dificuldades que possuem em comprá-lo, criticando o exagero da escola nas exigências quanto aos detalhes e o fato dela mandar os alunos de volta para casa por esse motivo. 


\section{3 - O significado da escolaridade para os pais}

\section{1 - Os professores vistos sob a perspectiva dos pais (p. 146)}

2- A visão dos nais sobre a Escola (p. 154)

3- O significado da escolaridade para os pais (p. 164)
3.1 - A importância do estudo para o futuro profissional dos filhos

3.2 - A escolaridade ajuda a vida em geral

3.3 - As dificuldades e desvantagens que os pais sentem por não terem podido estudar

3.4 - Expectativas de escolaridade para os filhos e o desejo de que eles possam ir além do grau que os próprios pais atingiram

3.5. - A vida escolar dos pais e justificativas pela interrupção dos estudos

Síntese dos resultados sobre o significado da escolaridade para os pais (p. 169)

4- O envolvimento dos pais na vida escolar dos filhos ( $p, 170)$

Figura 6 - Fluxograma relativo aos resultados das entrevistas individuais - (Tópico 3 )

\section{1 - A importância do estudo para o futuro profissional dos filhos}

Dezoito, entre os vinte e um entrevistados colocaram que o estudo é importante para o futuro profissional dos filhos. Alguns desses relatos podem ser observados a seguir:

"Por isso que eu falo pra elas: "O estudo é a melhor coisa que tem." Elas têm que estudá e muito, porque senão, ai elas vão casá com um pedreiro da vida, e vai sê costureira de sapato. (riso)" (Ilda)

"O estudo é em $1^{\circ}$ lugar.(..) Serve pro trabaio, né? Pra você trabalhá, entrá num trabalho bão... Pra você tê um emprego bão. Igual, por exemplo, o meu emprego, a minha vida num é fácil. Se eu tivesse um bom estudo, eu era empregada num outro lugar, com um salário melhor...(...) Porque, pra, cê, é, lavá fazê faxina, todo dia, vai 
indo cê enjoa daquele trabalho, né?(...) Às veiz tem pessoa que trabalha no facim, aí ó, de frente o computador. É uma coisa mais chique do mundo, né? Eu acho.” (Inês)

"Para você vê que até pra ser lixeiro tem que ter algum, algum grau de escolaridade.(...) Porque sem o estudo vocêis não é nada, né. Um pequeno serviço que cêis vai arrumar, ai se vocêis não tiver estudo, vocêis não entram. E não entram, não entra." (Luzia)

"Vai para escola porque hoje em dia até pra passar cola dentro de uma fábrica, cê tem que ter oitava ai, tem que tê currículo." (Sr. Mauro)

\section{2 - A escolaridade ajuda a vida em geral}

Alguns relatos apontaram que o estudo é importante para a formação da pessoa, para que ela se instrua para a vida, saiba conversar, tenha educação e possa acompanhar os fatos narrados pelos jornais. Esses aspectos podem ser verificados a seguir:

"O estudo é importantíssimo para a formação do caráter da pessoa, pra conseguir conquistas.(...) Formação da pessoa, né.” (Maria)

"Ah, hoje a gente tem que sabê de tudo porque senão você não faz nada, né? (...) É, se você não souber conversá, né? Fazê uma conta, né? É dificil pra vivê. Hoje depende, tudo depende do estudo, né?" (Jerusa)

"Você tem que saber das coisas senão você fica nesse mundo sem saber de nada, não tá por dentro das coisas. Sem estudo você não é ninguém, né. (...)Assim, vamos supor se eu não souber nada, eu vou ler um jornal, tá lá, tem muitas coisa no jornal, né. Eu não acho interessante a pessoa ser ignorante, entende?" (Luzia)

Outros relatos trouxeram situações difíceis sofridas por quem não tem estudo, tendo sido citados os seguintes aspectos: sem estudo a pessoa não é um cidadão porque nem os documentos pode tirar (sic), sem estudo a pessoa tem dificuldades de exercer as atividades cotidianas, quem não estuda abaixa a cabeça para tudo (sic), quem não estuda é considerado ignorante, é discriminado e fica sem assunto para debater com as pessoas que estudam. Alguns desses relatos podem ser verificados a seguir:

"Porque hoje, se ocê não tem o estudo, cê nem num existe, porque ocê num tem um documento, num sabe tirá um documento, num sabe assiná pra você tirá uma carteira, uma profissional, um RG, um CIC.(...) Então, cê nem num existe.Cê num é um cidadão, assim. É um João Ninguém, né?" (Dona Rita)

"Porque às vezes é pra anotar um recado, atender um telefone, anotar um número. Se a pessoa não tiver estudo, como que ela vai fazer isso, né?(...) Então a pessoa assim é muito mais dificil. Por exemplo pra circular na cidade, pra andar de ônibus, ler os bairros, precisa saber." (Rafaela) 
"Ela aceita tudo. Não aceita, ela abaixa a cabeça pra tudo. Agora, ela estudando, ela tendo mais desenvolvimento, ela sabe até aonde vai os limites dela, né? E a pessoa que não estuda é uma pessoa pacata." (Mariana)

"Pra viver hoje tem que sê assim. Você ser inteligente, você ser uma pessoa. Porque hoje em dia se você num estuda cê é considerado ignorante. Um dia eu senti ofendida, não sei se foi na loja que eu fui. A mulher olhou na minha cara e falou pra mim: a senhora sabe escrevê? Nossa menina, mais eu senti tão humilhada. Eu falei se eu não soubesse, agora como é que eu ia fazê. Eu ia ficá mais humilhada ainda. E eu falei pra ela: eu tenho cara de sê burra?" (D. Célia)

"Creio eu que o estudo, a parte mais importante do estudo é a parte social. Uma pessoa que estuda um pouco, ela tem, ela não é aceita na sociedade. E até mesmo pra si próprio, pra sobrevivê, ela tem que tê um pouquinho de cultura porque senão ela é, ela é discriminada, mesmo!(...)" (Fabiana)

A Dona Célia trouxe um aspecto diferente sobre a escolaridade, fazendo uma crítica à supervalorização do estudo na sociedade atual, apontando que os saberes práticos não são mais considerados. Ela colocou que quem não tem estudo é tratado como ignorante e que a exigência do mercado de trabalho quanto ao grau de escolaridade vem aumentando, mas que o ensino superior ainda é inacessível às pessoas pobres. Seu relato pode ser verificado a seguir:

"Eu acho, no meu modo de entender, que a educação num vem da letra não.(...) A sua educação vem do berço, da sua convivência, do seu dia a dia, do trabalho que cê passa, do aperto da vida que cê passa.(...) Cê num é burro e num é ignorante. Muitas veiz as coisa que cê passa num tá escrito nos livro. Cê aprende no tapa.(...) Eu aprendi foi no tapa.(...) Pelo menos daqui um tempo o $2^{\circ}$ grau completo num vai valê mais também não, cê vai tê que tê a faculdade. Ai o que vai acontecê, o governo vai tê que dá faculdade pro pobre. E isso ele num vai fazê, eu tenho certeza.(...) Então daqui uns dia, nem o $3^{\circ}$ colegial num vale mais." (D. Célia)

\section{3 - As dificuldades e desvantagens que os pais sentem por não terem podido estudar}

Os relatos a seguir mostram as desvantagens que os entrevistados sentem por não terem podido estudar. Uma delas acredita que "seria alguma coisa na vida se tivesse estudado"(sic), outra mostra seu desejo de ter tido estudo suficiente para poder, hoje, ajudar os filhos na escola. 
"Eu sinto muito não tê estudado muito, porque, às vezes, hoje eu até era uma coisa na vida." (Dona Rita)

"Estudei um pouco. O que eu sei eu não sei passar prá eles. O que eu sei assim é prá mim. Parece que eu não consigo, eu não consigo ensinar eles. Se for prá mim fazer uma conta no lápis, eu não faço e não adianta. De cabeça eu faço.(...) Às vezes vem lá uma matéria, elas falam prá mim: mãe, me ensina? Eu falo: eu não sei, pede prá sua tia ou pede prá outro.(...) Então eu acho que faz muita falta. Às vezes se eu tivesse estudado e soubesse ensinar eles desde pequenininho, eu mesmo. Às vezes hoje não era assim, né." (Roberta)

Outras mães relataram o arrependimento por não terem estudado, como exemplificado pela fala da Gisele:

"Por exemplo, o meu pai que só tinha eu de filha. Ele queria que eu tivesse estudado, que eu tivesse formado e eu nunca gostei, pra te falar verdade, eu nunca gostei de estudar. Mas hoje eu me arrependo porque eu acho faz muita falta. Porque eu penso às vezes em voltar a trabalhar quando os meninos tiverem maior. Mas eu não tenho uma profissão." (Gisele)

\section{4 - Expectativas de escolaridade para os filhos e o desejo de que eles possam ir além do grau que os próprios pais atingiram}

A Inês, a Dona Rita e a Ilda colocaram o desejo de dar aos filhos o que seus pais não puderam lhes proporcionar, desejando que, através da escolaridade, eles pudessem ir além dos seus próprios conhecimentos:

"Porque num dianta pô no mundo e num dá educação... Porque eu num tivo, né? Educação, assim, que eu falo, sobre a escola, né? Um estudo suficente. Então, o que eu num tive eu quero dá pro meus filho. Eu quero dá o melhor pra eles." (Inês)

"Elas falam assim: "Ah, hoje a, nós têm aula de inglês. Hoje nós têm aula de ciência. Hoje nós têm aula de não sei o que.(...) Então, eu acho, assim, bonito, né? Porque eu não cheguei, né? Assim, tê isso, né?(...) Nem sabia o que significava isso, né? Que os pais da gente não explicava muito pra gente o que que é.(...) Nem sabia porque que tava acontecendo aquilo no mundo." (Dona Rita)

"Eu saí (da escola) porque na minha época... É igual, eu vô te falá, a minha mãe, quando abandonô nóis, igual, minha mãe num mora cum nóis. Igual, ela largô a gente pequeno. Eu tinha 9 ano na época.(...) E eu não tinha, assim, uma pessoa pra chegá pra mim e falá: "Minha fia,n o dia de amanhã isso vai te fazê falta." (Ilda)

Outros entrevistados falaram sobre as expectativas que possuem acerca da escolaridade dos filhos. A Rafaela e a Jerusa esperam que seus filhos terminem pelo 
menos o colegial. A Elza deseja formar a filha "professora" e a Valéria deseja formar a filha em qualquer coisa. Mas essa possibiliade parece remota; se houverem condições, se o pai pagar a pensão, se Deus quiser (sic). Alguns dsses relatos podem ser observados a seguir:

"Eu penso que eu queria demais formá minha fia.(...) E o pai dela é muito bem de situação, né? (...) Aí, pelo meno ela já tem o dinheiro pra podê, pelo meno formá professora.(...) Uma professora, um, uma coisa, assim, que num precisa estudá tanto, né?" (Elza)

"Se Deus ajudá que ele faz, pelo menos o colegial, né? Que a faculdade hoje é dificil, só se... Só se tivé um bom emprego e... E pudé pagá." (Jerusa)

"Eu se pude eu vô deixar minhas filha até elas se formá alguma coisa. Se eu tivé condições elas vão continuar." (Valéria)

\section{5 - A vida escolar dos pais e justificativas pela interrupção dos estudos}

Alguns entrevistados relataram a própria história escolar, apontando as vivências negativas e justificando a interrupção dos estudos: ou por dificuldades da vida na roça, ou por ter que conciliar trabalho e escola, ou por um história escolar negativa e até devido a uma vida muito tumultuada, como pode ser exemplificado nos relatos seguintes:

"Sai da escola em 4 ano, no quarto ano, estudava de manhã e depois do almoço eu tava dentro da fabriqueta trabalhando. Num tinha esse negócio de ficá jogano bolinha de gude, soltá pipa, num era assim não." (Sr. Mauro)

"Parece que eu ia obrigada prá escola.(...) Eu não sei, eu não entendo hoje porque eu não gostava de estudar.(...) Tinha uns professores lá que não valia nada. Nós morava no Paraná, era roça. Então tinha um professor que agredia a gente. A gente agredia ele. Era uma coisa mais assim sabe... Não é igual hoje. Eles colocava a gente de castigo em cima de caroço de milho, na tampinha de garrafa, atrás da porta com os braço aberto. Hoje não tem isso, hoje é crime fazer isso. Reguada na mão, na cabeça, quantos e quantos eu levei, menina. (...) Eu acho que um pouco é isso, medo que a gente tinha." (Roberta)

"Não, eu, eu, bom, eu, o meu, meu estudo foi interrompido, né? Devido à, minha, minha vida, muito tumultuada, e eu, eu, né? Mais, eu, sei lá, terminei, eu estudei numa escola boa em São Paulo e, de repente, eu nunca, assim, me senti muito...(...) Incentivada pra estudá.(...) Quem me criô foram as freiras." (Carolina)

"Tinha que i de pé, longe, iche! Andava uns $10 \mathrm{~km}$ de pé. Todo dia. E pequena, né? Porque a gente era pequena, 7, 8 anos. E ia sozinha. (...) Eu falo que eu enfrentava 
enchente, vaca brava... (riso) Ih, nóis passava no meio de tanta vaca brava pra i na escola que nossa senhora...Tinha que corrê." (Jerusa)

\section{Síntese dos resultados acerca do significado da escolarização para os pais}

Quando incitados pela pesquisadora a falar sobre esse bloco temático, os entrevistados em geral não tiveram dificuldades em se expor. A maioria deles adotou o caminho de emitir avaliações sobre o estudo mas, também, foram construídas narrativas que envolviam esse tema.

Os entrevistados unanimemente mostraram valorizar a escolarização dos filhos, vista por eles como meio de ascesso a bens culturais e materiais. Alguns pais narraram, também, situações difíceis sofridas por quem não tem estudo. Outros relataram as desvantagens que sentem por não terem podido estudar.

Uma única entrevistada fez críticas à supervalorização do estudo na sociedade atual, apontando que quem não tem estudo é tratado como ignorante. Ela afirmou, também, que a possibilidade de ascenção social por meio do estudo, ainda é pequena para as pessoas pobres.

Alguns pais relataram sua expectativa quanto à escolarização dos filhos, mostrando que esse é apenas um desejo, dependente de várias condições para poder se realizar.

Por fim, alguns entrevistados narraram situações acerca da sua própria vida escolar, justificando-se pela interrupção dos estudos. Nota-se nesses relatos, uma postura mais defensiva.

\section{Consenso quanto à valorização da escolarização dos filhos}

Explicações cognitivas: a escola parece ser vista como o único caminho para uma possível ascensão social

(mesmo que as expectativas de que isso realmente ocorra sejam pequenas)

Relatos de vivências que revelam como é ter pouco estudo na sociedade atual. Os entrevistados destacaram a discriminação vivida devido à falta de escolarização e o sentimento de inferioridade por ela causado.

Portanto, o fato de não estudar parece não ser uma escolha, mas uma conseqüência de situações de vida inesperadas que terminam por impossibilitar a permanência na escola. 


\section{4 - O envolvimento dos pais na vida escolar dos filhos}

\section{4- O envolvimento dos pais na vida escolar dos filhos (p. 170)}

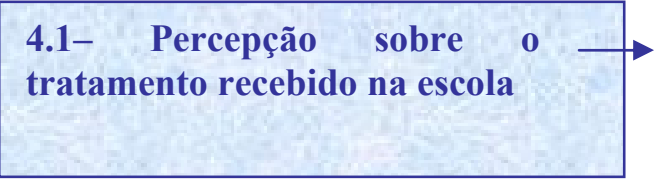

4.2 - A participação dos pais na escola

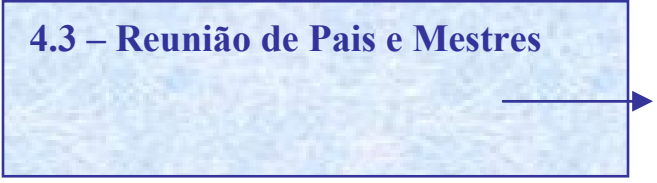

$4.4-O$ acompanhamento escolar dos filhos

4.5 - Compreensão dos pais quanto às dificuldades escolares dos alunos
4.1.1 - Abertura da escola

4.1.2 - Tratamento recebido na escola

4.2.1 - Apoio financeiro

4.2.2 - Participação dos pais nas tomadas de decisão

4.2.3 - Trabalho voluntário dos pais na escola

4.3.1 - Comparecimento dos pais

4.3.2 - Descrição das reuniões

4.3.3 - Visão Positiva sobre as reuniões

4.3.4 - Críticas a outros pais

4.3.5 - Críticas às reuniões de pais

4.4.1 - Percepção de que os professores responsabilizam os pais pelo acompanhamento escolar dos filhos

4.4.2 - Atribuição de importância pelos pais na aiuda às tarefas escolares

4.4.3 - Relatos de situações de auxílio dos pais aos filhos na escola

4.4.4 - Dificuldades que impedem os pais de acompanharem os filhos na escola

4.4.5 - Impotência dos pais em conseguirem aue os filhos melhorem na escola

4.4.6 - Discordância entre pai e mãe

4.5.1 - Apoio irrestrito à escola

4.5.2 - A escola pode ser responsável

4.5.3 - Ambigüidade

4.5.4 - Explicações extra escolares para as dificuldades de aprendizagem dos filhos

Síntese dos resultados acerca da visão dos pais sobre o envolvimento dos pais na vida escolar dos filhos (p. 189)

Figura 7 - Fluxograma relativo aos resultados das entrevistas individuais (tópico 4). 


\section{1- Percepção sobre o tratamento recebido na escola}

Esse tópico foi trazido pelos pais segundo as seguintes perspectivas: abertura da escola à participação dos pais e tratamento recebido na escola.

\subsection{1 - Abertura da escola à participação dos pais no cotidiano escolar}

Alguns relatos apontaram como característica positiva da escola, o fato de que existe uma abertura (especialmente por parte da diretora) para que os pais participem dando suas opiniões nos assuntos relacionados à vida escolar:

"Tá aberto. Qualquer hora que a gente chegá lá e falá: olha, dona Sônia (diretora), isso precisaria ser mudado. Ela senta, vai ver, vai questioná: o que você acha? o que você acha que tá faltando? O que você acha que precisaria? Ela senta com os pais ajudando na escola, né." (Rose)

"A diretora fala: "quem quiser ficar para conversar com os professores, expor opiniões..." Ela sempre fala isso nas reuniões. "Pode ficar". E também tem na segunda-feira. Toda segunda o professor termina as aulas, ele fica na escola porque se os pais quiser ir lá conversar com eles, fora assim, dia de reunião." (Rafaela)

"É uma escola, vamo dizer assim, é mais, mais, tem uma coisa que é, as pessoa participam mais.(D: Os pais, o senhor fala?) É, o que deu pra mim perceber foi isso. As pessoa participam mais. A própria escola abre esse parâmetro pra gente.(...) Não, de querer participar, de ajudar em alguma coisa, em prol do seu próprio filho mesmo, em prol da escola, uma série de variedade, vamo dizer assim." (Sr. Mauro)

\subsection{2 - Tratamento recebido na escola}

Vários relatos apontaram a boa receptividade da escola para com os alunos e pais, ressaltando o bom atendimento nela recebido, mostrando uma proximidade afetiva do ambiente escolar, principalmente com relação à diretora, como pode ser exemplificado pelas falas da Valéria, Gisele e Sandra:

\footnotetext{
"Porque a diretora é assim, é mais educada prá conversar com a gente.(...) O que a gente puder conversar com ela, a hora que for ela atende a gente. (...) Ela respeita, ela é muito boa prá essas coisas, muito educada, muito atenciosa, ela dá muita atenção prás mães.(...) Os funcionário conversa com a gente. Conversa bem com a gente." (Valéria)
}

"A Sônia é muito amiga de todo mundo, ela conversa muito. Ela fala assim: gente eu tô aqui pra ouvir todo mundo, eu tenho a minha opinião mas eu posso mudar quando 
eu converso com as pessoas. Então eu acho que ela dá espaço prá gente falar o que a gente pensa e se ela achar que foi um jeito que a maioria pensa, ela muda de idéia.(...) Eu não sei se é por ela ser do jeito que ela é que ela conseguiu atrair essas mães pra escola, pra todo mundo ajudar.(...) Eu nunca ouvi a dona Sônia, nem pra uma criança, eu nunca ouvi ela alterar a voz. Ela dá as broncas sempre naquele tom de voz que você vê. Em nenhum momento ela altera a voz dela. Ela trata todo mundo bem." (Gisele)

"A dona Sônia é muito responsável. Assim, ela é muito dedicada, tá sempre indo atrás de coisa, igual foi agora.(...) Fica sempre...procurando fazê assim, procurando que os pais venham participar também. Ela não é assim: "eu sou diretora, eu faço". Não, ela fala: "não, a escola não é só a diretora, a escola é a diretora, os pais, os professores, os alunos, tudo mundo junto". Então ela não decide nada sozinha. Tudo que vai decidir lá ela convoca os pais, fala, sabe? Pergunta se concorda, tudo, é assim. Eu acho que ela dá muito espaço." (Sandra)

Já algumas entrevistadas enfatizaram o fato de não serem bem recebidas pela escola, não sendo ouvidas ou acatadas pelos seus funcionários e professores. Destaca-se aqui, especialmente o relato da Roberta, cujo não atendimento adequado pela professora, fez com que sua disposição em atender às solicitações da escola diminuísse, sendo essa uma possível causa do seu afastamento.

\begin{abstract}
"Igual uma vez que eles falaram pra mim ir. Ela (a filha) chegou aqui correndo. Eu sai do serviço, cheguei em casa.(...) "Mãe, a senhora não foi na escola? Vai correndo." Eu peguei e fui. Ela falou: "a professora disse que é pra a senhora ir que ela quer conversar com a senhora." Eu larguei os menino e correndo eu fui. Cheguei lá, menina, nem lá fora ela saiu pra me atender.(...) Falou que não podia naquele horário. Então, eu também não podia largar meu serviço.(...) Falou pra mim ir, cheguei lá... Aí eu falei: "agora eu não vou mais." A hora que me chamar eu não vou mais. Só se eu não tiver nada pra fazer, mas se eu tiver alguma coisa, não tem como sair e chegar lá.(...) E os horários que elas pedem pra gente ir não tem como. Ela falou pra mim ir 1 hora. E o serviço?" (Roberta)
\end{abstract}

Outros relatos trouxeram críticas à maneira com que a vice-diretora trata os pais e os alunos, como pode ser exemplificado a seguir:

"A vice-diretora, um dia eu vi ela sendo grossa lá com uma mãe por causa do horário de vender camiseta. A mãe foi, queria comprar fora do horário e ela não vendeu.(...) Às vezes a mãe não pode nem ir outra hora, ou às vezes tá passando por alí, às vezes trabalha. Ela não abre exceção." (Gisele)

"Porque a, ali na escola, a baixinha (vice-diretora), eu chamo ela de baixinha, né? (...) Mais, ela chama a atenção da, das mães, na frente de qualqué um, sabe? Ese tivé que chama a atenção do professor, também, ela chama.(...) Porque ela num dá, ela num dá chance pra te ouvi. Ela solta os cachorro. Num é?(...) Cum ela num adianta falá, porque ela disconversa.(...) Num dá atenção.” (Cibele) 


\title{
4.2 - A participação dos pais na escola
}

A participação dos pais na escola, segundo os relatos dos entrevistados ocorre através do apoio financeiro, ajuda em tomadas de decisão e trabalho voluntário.

\subsection{1 - Apoio financeiro}

Algumas entrevistadas relataram que a escola faz campanhas para arrecadar dinheiro dos pais com o objetivo de melhorar a escola. No entanto, três delas se queixaram da falta de retorno e mostraram dúvidas com relação à utilização do dinheiro, como pode ser exemplificado pela fala da Elza:

\begin{abstract}
“... a diretora rancô dinhero nosso, disse que ia colocá 3 bebedor. Ela rancô dinhero nosso, do povo, dos pais, pedindo litros de óleo. Eu mesmo mandei 3 litro de óleo, na época que tava pedino, que, ai eles vendia pra podê pô bebe, pô bebedoro.(...) Pois só um e disse que com o dinheiro ia comprá os bebedoro e pô, e reformá os banhero, que os banhero também tá um, uma narquia." (Elza)
\end{abstract}

\subsection{2 - Participação dos pais nas tomadas de decisão}

Somente três entrevistadas relataram participar de tomadas de decisão junto à escola. Apesar de aparentemente essas mães se referirem a um forum de discussões onde se trata de assuntos ligados ao cotidiano escolar, o que pode ser percebido, é que as discussões se voltavam mais para os problemas práticos do bairro e da escola, tendo como objetivo, conseguir ajuda para resolvê-los:

\footnotetext{
"Porque às vezes tem muita gente que vem de fora do bairro que quer fazer bagunça, então a gente já entra em contato. Pessoal na porta de escola, né.(...) A gente sempre trata disso.(...) No começo muitos pais tava participano, depois parece que eles esquece, desanima, né..(...) Geralmente os pais que tão lá, são os filhos que não dão problema, né. Qué tentá ajudar os outros, mas os outros geralmente não participam.." (Rafaela)

"Tá sempre marcando aquela reunião todo mês, todo mês tem aquela reunião: olha eu não tô podendo pagá isso, nóis vamo fazer uma festa. Faz festa, arrecada. Precisa arrumá isso, precisa de pintá, precisa disso, daquilo. Os pais chegam junto." (Rose)
} 
Duas mães relataram ser membros da APM (Associação de Pais e Mestres), sendo que uma delas relatou a participação na escolha da nova orientadora pedagógica da escola e a outra relatou ser membro da APM por pedido da diretora, mas disse que não participa das reuniões e não tem muitas informações:

\begin{abstract}
"Porque eu faço parte da APM e do conselho da escola. No conselho de escola era para reunir em um dia pra votar nas coordenadoras, que tinham 5.(...) Ai foi a eleição pra votar nessa que tá ai agora." (Gisele)

"Sou da APM. Conselho fiscal da APM. (D: E como que funciona a APM aqui na escola?) Ah, acho que ela arrecada dinheiro, não sei bem pra... É, faz é, promoção de festa, né? Bazar...(...) (D: Vocês têm reunião da APM?) Tem, costuma ter à noite.(...) Eu acho que é todo mês, mas eu não costumo vir não.(...) Ela (a diretora) que falou que eu era, como eu sou mãe de aluno, se eu queria entrar, ela falou se eu queria entrar, eu falei que tudo bem, pra mim tudo bem." (Mariana)
\end{abstract}

\title{
4.2.3 - Trabalho voluntário dos pais na escola
}

A Rose colocou que se sentiu bem ao fazer trabalhos solicitados pela escola, por exemplo, lavar as cortinas voluntariamente:

"Igual inclusive nesses tempo a dona Sônia (diretora): "nossa gente, o governo manda dinheiro e não tá dando pra lavá as cortinas, não deu pra isso, não deu pra aquilo." Tá precisando lavá cortina? Então mandá lá pra casa, a gente lava. Trouxemo as cortina pra casa, lavamo as cortina da escola. Então cê vê a gente tá sempre ajudando. Então é uma coisa que não pode acabá não." (Rose)

A Valéria colocou, ainda, que gostaria de ajudar como amiga da escola, mas não pode por causa do trabalho:

"Acho que tem que tê participação na escola também. Só que quando elas chama prá podê ajudar na escola, as mães pode ajudar igual o amigo da escola, você sabe... Eu mesmo não posso ir, entendeu... Trabalho, né. Mas eu gostaria de ajudar, só que sinto muito mas...(...) Três criança, costura em casa, então. Mais um dia se elas precisar e eu tivé disponivel, a gente pode ir." (Valéria)

Já um dos relatos apontou claramente que a mãe ajuda a escola não somente porque gosta, mas para que as professoras não reclamem dela:

“Eu já viajei com as professora, lá pro Castelim... Levando os aluno. Eu sô uma pessoa da hora. Que se eu num tivé trabalhando, me chamô, eu tô junto, né? Então, eu gosto, assim, de ajudá, né? Corrigi as criança. Eu oiei tudo as criança, o que eu 
pude fazê eu fiço, né? Então, num tem, eu acho que elas num tem o que reclamá de mim, né?" (Inês)

A Carolina, a Rafaela e a Gisele relataram suas experiências como "amigas da escola" de forma positiva, mostrando como conseguiram fazer amizade com as crianças mais "rebeldes"(sic), criando um vínculo positivo com elas. As mães mostraram valorizar muito esse fato:

"Eu passei por uma experiência muito bonita, sabe Daniela? Quando eu cuidava dos alunos, eu, eu pedia pra diretora brinquedos, é, educativo, é, joguinhos, eu falava de Deus e, eu acho que Deus me usava naquela escola.(..) As crianças, porque tinha uns meninos rebeldes... Eu sentava, aproveitava aquele pouco tempo de recreio e conversava com eles.(...)Depois, com pouco tempo, eu vi aquele menino outro. Num era mais aquele menino rebelde, correndo, agressivo. Ele mudô.(...) Cê tá vendo?(...)Quando eu vô na escola ele vem correndo e me abraça... Ele gosta de mim." (Carolina)

"Eu tô sempre lá na escola. Sempre pra ajudar na escola na hora do recreio, pra ajudar a olhar as crianças.(...) Porque às vezes não tem condições de pagar funcionário pra isso, né. Então a gente faz isso, voluntário, é trabalho voluntário.(...) Tem uns (alunos) que é mais dificil, mas a gente faz amizade com eles, né. Ai tem uns aluno que é meio agressivo, cê começa a brincar com eles, conversar. Ai cê vai todo dia e eles já conhece a gente e ai faz amizade. (...) Ai eles já começa a chamá a gente de tia. É muito legal." (Rafaela)

"Nas férias por exemplo, eu sofri muito de não tá indo lá.(...) Eu fiquei com saudade deles, porque a gente se apega. Tem muitos ali que é criança carente, que chega e te abraça e te chama de tia.(...) Então eles são carinhosos, entendeu?(...) Eu resolvi me dedicar na escola, porque tem sempre uma criança que a gente vê que tá precisando, tudo né.(...) Tudo que eu posso fazer pra eles eu quero fazer." (Gisele)

A Gisele colocou ainda outros aspectos com relação a essa função de "amiga da escola". Primeiro, que os filhos gostam que ela seja amiga da escola, segundo, apontou as críticas de outras mães, pelo fato dela ser amiga da escola. Ela ressaltou, ainda, a percepção das difículdades vividas pelas famílias mais carentes da escola e a importância de que esses pais sejam tratados com um maior cuidado, para que não se ofendam. Esses aspectos podem ser observados na sua fala:

\footnotetext{
"Mais assim, cê vê que eles (os filhos) sentem bem da gente estar lá."

"O que a gente percebe é que elas (algumas mães) têm ciúme, que ficam falando que a gente é puxa saco da dona Sônia, puxa saco da escola.(...) E não é que a gente é puxa saco, é que a gente quer o bem estar da comunidade, no caso de todas as crianças. Inclusive a gente vai pra olhar também o delas. Mas tem muitos que falam isso pra gente, inclusive o homem lá na reunião falou que isso é coisa de quem não tem o que fazer."
} 
"Eles são em 6 irmãos, o pai é trabalhador, só que ganha pouco. A mãe costura sapato em casa. Então tem dia que ele chega na escola e fala que tá com dor no estômago porque faz 2 dias que não come arroz.(...) Então eu venho aqui em casa, eu busco comida, levo lá na escola, dou prá ele.(...) Porque eu vejo que ali as famílias tem muito filho, que não dá pra dar atenção pra todo mundo. E eu acho que escola que é mais carente, eu acho que as crianças são assim. Eu acho que eles precisam é isso. Desse carinho, eu acho.(...) Eu acho que com as pessoas mais carentes, ainda tem que ter muito mais jeito pra falar, do que com quem tem mais um pouquinho de estudo, alguma coisa assim.(...) Eu acho que as pessoas mais humildes, não é porque é humilde que não mereça ser tratada bem, não é.(...) Igual tem muitas crianças que você vê ali, que chega ali não toma nem banho e cê vê que está com a roupinha toda suja. A gente não sabe o que tá acontecendo lá na casa dele. Mais às vezes a mãe não tem nem tempo. Tá costurando o sapatinho dela lá. Porque tem um monte que vai ali na escola, todas as mães costurando sapato. Vai buscar os meninos, elas ficam com os sapatinhos, costurando na rua. Vai buscar de tarde tá costurando. Então cê vê que as pessoas são sofridas." (Gisele)

\section{3 - Reunião de Pais e Mestres}

Sobre o tema reunião de pais e mestres, os entrevistados trouxeram questões acerca do comparecimento dos pais, fizeram relatos descritivos sobre como ocorrem, além de relatos que apontaram uma visão positiva sobre as reuniões, crítica aos pais que não participam e críticas às reuniões.

\subsection{1 - Comparecimento dos pais}

Em alguns relatos observou-se que as mães sentiam-se pressionadas pela escola para comparecerem às reuniões. Uma delas se justificou por não poder ir e outra afirmou que por causa dessa percepção, não deixa de participar. Ela afirmou que teme o fato de ficarem ressentidos com ela na escola e por isso comparece sempre. Esses relatos podem ser observados a seguir:

"Ela (a filha) falou prá mim agora: "Mãe teve reunião e a senhora não foi, a professora falou prá senhora ir lá." Eu falei: "minha filha, a hora que eu tiver um tempinho eu vou lá." "Mas ela falou que não vai deixar nóis entrá, ela falou que nóis num podemo entrá se a senhora não for lá." Eu falei: "fala pra ela que eu não posso ir. " Elas já sabem a minha história! (em tom de lamento).(...) Às vezes a gente até quer, tem vontade. Qual mãe que não quer tá por dentro de tudo do filho? Mais num tem como." (Roberta)

"Eu vou em todas (as reuniões). Em todas, porque senão eu acho que elas (pessoas da escola) fica sentida. Ai se você vai chamar a atenção (da escola), não tem como. "Você não vai nas minhas reunião." Então eu vou, mas saio assim: por que eu vou? O que eu vim fazer aqui? Só assinar a lista de presença?(...)E, chega lá sempre as 
mesmas coisas, não muda. Você já sabe o que vai falar. Então, a maioria dos pais, a maioria, já vai desanimado, vai prá assinar a lista de presença. Porque se não assinar, depois vai ser cobrado." (Maria)

A Shirley disse que gosta das reuniões e que não faltou em nenhuma. Em seguida ela justificou que gosta de ir porque "tem que estar presente" e, contraditoriamente, disse que quando não vai, a filha chora. Seu relato pode ser verificado a seguir:

"Eu gosto, eu vou em todas, não faltei em nenhuma. Eu acho importante pras criança. É, tem que tá presente, né, um pouco. Quando eu num vou, ela, a Jaqueline chega até chorar. (...) Porque eu não sou de ir em escola, né. Igual muitas mãe vai." (Shirley)

A Rafaela, a Mariana, a Valéria e a Luzia colocaram que sempre comparecem às reuniões, mostrando valorizar essa participação de maneira genérica, mas sem colocar os motivos que as fazem gostar da reunião, como pode ser exemplificado pela fala da Luiza:

"E assim todas as reunião eu participava, eu não faltava não. Saia do serviço e ia. (D: E você achava bom participar das reuniões?) Eu achava bom, né. A gente tem que participá, né." (Luzia)

Outros entrevistados relataram buscar comparecer às reuniões de pais e mestres na escola, mas justificaram que muitas vezes ficam impedidos de fazê-lo, principalmente por falta de flexibilidade no horário de trabalho. Quando isso ocorre, a maioria afirma enviar alguém no seu lugar, como a sogra ou uma amiga. Uma das mães colocou, ainda, que sua filha mais velha assumiu as reuniões das irmãs mais novas. Alguns exemplos desses relatos podem ser observados a seguir:

“Às vezes nem em reunião eu posso sair e ir. Porque não tem como, se eu tiver trabalhando fora. Aonde eu tô trabalhando acha ruim, não gosta que a gente sai.(...) Às vezes eu até quero ir. Tenho vontade de ir, sabe." (Roberta)

"Não, eu vou, sempre que tem reunião, assim, que eu posso, eu vou.(...) Dai, sempre eu tô indo. Quando eu não vô a minha sogra vai pra mim, você entendeu?” (Ilda)

Alguns entrevistados colocaram, ainda, que participação dos pais nas reuniões é importante para que fiquem a par dos problemas dos filhos, para que possam, assim, fiscalizá-los: 
"Nas reuniões, é, eu acho que o obje, o, o objetivo das reuniões é você sabê o desenvolvimento do seu filho, entende? O que ele tá fazendo de bom e o que ele tá fazendo de ruim." (Carolina)

"Porque a gente chega na escola, a gente vai conversá, a, o aluno, seu filho tá, assim, tá bom demais. (...) Mas eu quero sabê se ele tá dando trabalho, se ele tá sendo um bom aluno, se não tá dando problema no dia-a-dia." (Silvia)

\subsection{2 - Descrição das reuniões}

A Dona Rita, a Valéria e a Luzia descreveram como são as reuniões, destacando aspectos como: conversam muito, explicam como utilizarão o dinheiro a ser arrecadado, explicam como os pais devem lidar com os filhos, como pode ser exemplificado a seguir:

"O que tem, assim, que vai acontecê o ano inteiro, eles já passam na primeira reunião. Elas explicam tudo.(...) O que vai arrecadá, o que não vai, o que é pra ajudá, o que não é, o dinheiro que é pra dá, pra que é aquele dinheiro...Pra onde que vai aquele dinheiro." (D. Rita)

"E tinha as reuniões também dos pais.(...) Ai ela falava assim, os alunos tá conversando em geral. Mães, vocêis procurem falar com os alunos, né. Isso, ela falava isso." (Luzia)

\subsection{3 - Visão Positiva sobre as reuniões}

Os relatos que justificaram o porque das reuniões serem boas se mostraram superficiais, sendo ou porque os professores falam bonito, ou porque a escola mostra seus méritos, ou até porque esta merece apoio irrestrito. Aparece aqui uma tentativa dos pais de se adequarem ao que é pedido pela escola. Esse aspecto pode ser verificado a seguir:

"Então, na, é, na reunião que eu fui é que tava falando sobre, dos pais na, na escola, né?(...) Achei boa. Então, os professores falaram muito bonito, então, eu achei muito, muito legal, lá. (...)Reunião muito boa. E todas que eu fui, também, a gente falô sempre o que era preciso falá, né? Sobre assunto de moda, de roupa, de visti e tudo. Então, quando é uma roupa que num tá adequada na escola, às veiz elas vêm e falava pra gente. A gente, que é pra gente corrigi e comprá outra roupa, do jeito que elas queria..." (Inês)

"Tem que, só falam das crianças, né? (...) O que elas faz pra consegui, né? Chegá até onde elas chegô, porque, pra vê, as crianças do jeito que estão, né? Que as crianças 
lá são crianças bem comportadas, né? Porque o menino que é danado, ele é excluído da escola.(...) Mais, são umas reunião muito boa, sabe?” (Dona Rita)

\subsection{4 - Críticas a outros pais}

Em alguns relatos observou-se a repetição do discurso comumente ouvido na escola, de que os pais, (alguns entrevistados colocam que são aqueles que mais precisam) não freqüentam as reuniões, saem mais cedo, falam muito e fazem perguntas bobas. Os relatos mostram essa crítica, sendo que a Rafaela coloca a percepção de que alguns pais, por se sentirem cobrados nas reuniões, se afastam da escola:

\footnotetext{
"Os pais que têm interesse nos seus filhos ter um ótimo estudo, um ótimo ensino, os pais vão (nas reuniões). Agora aqueles que cê vê, os mais chamado, que às vezes a criança tá dando trabalho na escola, eles não vão. Isso aí deixa a gente muito triste.(...) Mais aqueles que tem mais problemas, os pais mesmo não aparecem.(...) São aqueles que nem participar de reunião não participa." (Rose)

"Tem pai que não aceita não, mesmo ali dentro, na hora da reunião, dependendo do que cê fala, às vezes encaixa.(...) Tem pais que não aceitam não.(...) Tem uns que às vezes por causa disso já afasta.(D: Por causa da opinião de outro pai?) De outro pai, porque às vezes você fala uma coisa que tá servindo pra ele.(...) "Pais que não participam da escola, não ajuda os filhos na lição." Às vezes aquilo serviu para ele, ai ele já, ao invés de tentar enturmar, né, conversar, tem uns pais que já afasta." (Rafaela)
}

\subsection{5 - Críticas às reuniões de pais}

Oito entrevistados fizeram críticas às reuniões, sendo que o primeiro relato exposto a seguir apontou a ocorrência de preconceito racial por parte das professoras com relação a alguns pais na reunião. Quanto à natureza dos assuntos abordados, foi colocada que a ênfase é nas obrigações dos pais e no comportamento dos alunos. Os pais relataram falta de espaço para que opinem nas reuniões, que são vistas, também, como chatas, cansativas e demoradas, o que gera desinteresse da maioria:

\footnotetext{
"Nas reuniões que eu já participei a gente vê.(...) Trata diferente um pai, as pessoas, um pai com cor diferente.(...) Às vezes é uma pessoa muito simples e a professora nem chega perto para conversar. Quando já é um pai que tá mais arrumado, chega, fica perto, conversa. Você vê que é uma pessoa mais, que a pessoa tá assim mais
} 
suja, eles tem o preconceito, a gente percebe.(...) Assim, acho que sente humilhado, diferente." (Rafaela)

"Ás vezes cansa...(...) Não sei, não chega naquilo que a gente quer ouvir. O que o aluno tá aprendendo, e que o ensino tá sendo bom.(...) Mais é o assunto de relacionamento de aluno com professor, né.(...) É. Particularmente do aluno (...)." (Maria)

"Deveria os pais opiná, também. Mas eu acho que eles num têm liberdade de levantá o braço.(...) Num abre espaço pros pais falarem.(...) Porque cansa muito, fala muito sobre: "É, porque os filhos, os pais tem que fazê assim; o uniforme..." É coisa que a gente ouve todo ano. Sabe? Os pais vão cansando, ai vão indo embora." (Carolina)

"Ah... reunião sempre é chata, né? Por menor tempo que seja, por mais tempo que seja. Reunião, num tem uma reunião boa.(...) É cansativa toda reunião.(...) Sem interesse pros pais." (Fabiana)

Essa última mãe ainda colocou como devem ser as reuniões: mais individualizadas e aconchegantes para que haja uma melhor participação dos pais:

"Eu acho que a reunião deveria ser especifico, cada sala com os seus professores e não uma reunião geral, porque ali num tem como cê discuti um assunto individual.(...) Pra fazê aquela coisa ficá mais, uma relação mais aconchegante. Não essa relação fria, distante, que tem pais e professores e alunos. Pra tê uma participação melhor." (Fabiana)

\section{4 - O acompanhamento escolar dos filhos}

O tema acompanhamento escolar dos filhos foi visto pelos entrevistados dentro das seguintes perspectivas: percepção de que os professores responsabilizam os pais pelo acompanhamento escolar dos filhos, atribuição de importância pelos pais na ajuda às tarefas escolares, relatos de situações de auxílio dos pais aos filhos na escola, dificuldades que impedem os pais de acompanharem os filhos na escola, impotência dos pais em conseguirem que os filhos melhorem na escola e discordância entre pai e mãe. 


\subsection{1 - Percepção de que os professores responsabilizam os pais pelo acompanhamento escolar dos filhos}

Os relatos a seguir apontam a percepção da cobrança dos professores para que os pais cuidem da tarefa escolar dos filhos e, ao mesmo tempo, essa ação é vista como legítima e importante pelos entrevistados:

"Só que elas fala, né, que é prá mim ajudar a Denise em casa. Todas as professora fala mesmo, né." (Valéria)

"(D:A senhora falou também que quando não faz a lição de casa os professores chamam a atenção?)Chama.(D: Da criança ou da senhora?) Da gente e das crianças. Chama porque eles ficam prestando atenção, porque a criança não tá fazendo a lição.(...) Então eu acho, assim, que isso é um direito que eles têm, né? De procurá sabê porquê o pai não tá tomando consciência, né?" (Dona Rita)

Um outro aspecto percebido no relato do Sr. Mauro é que ele sente medo de ser criticado pela professora, se preocupando com a manutenção do material escolar do filho, porque se precisar comprar outro e a família não tiver dinheiro, o pai acha que a professora vai pensar que os pais não "dão bola" para o estudo do filho:

"Igual esse ano, eu falei; "Gente, olha, comprou aquele tanto de caderno, isso, aquilo." Porque tem que comprar. A escola num é obrigada a dar, então cê valorize, isso custa dinheiro. Chega amanhã precisa comprar mais alguma coisa, o pai num tem dinheiro, a mãe num tem, como é que faiz? A professora vai achar que a gente num tá dando bola, mais é porque num tem.(...) Num tem mesmo. ”(Sr. Mauro)

\subsection{2 - Atribuição de importância pelos pais na ajuda às tarefas escolares}

Alguns entrevistados enfatizaram a importância de que os pais acompanhem de perto a vida escolar dos filhos. A Rose ressaltou a necessidade da constante comunicação com a escola e a Rafela colocou que os pais têm mais responsabilidade que os professores no que diz respeito à aprendizagem da criança. O Sr. Mauro atribuiu a causa de alguns insucessos na própria vida ao não acompanhamento dos seus pais, que não tinham estudo suficiente para isso e a Luiza trouxe uma crítica a uma mãe que é analfabeta e não consegue ajudar o filho na escola. a seguir: 
"Eu chego junto com a professora, com a diretora sempre. Quero saber como que o meu filho tá na escola." (Rose)

"Eles vão lá, faz a parte deles, eles ensina.(...) Acho que o fundamental são os pais mesmo." (Rafaela)

"Eu tive terreno aqui no Brasilândia, eu tive terreno na Santa Cruz, eu tive uma pá de coisa. Perdi e cêis acham porque?(...) Eu num tive esse acompanhamento que vocês moçada tem hoje. Minha mãe não tinha leitura, meu pai muito pouco." (Sr. Mauro)

"Eu tenho uma amiga aqui, ela não sabia ensiná nada. Porque ela não sabia ler. (...) E o menino coitado não aprendia.(...) Como que eu posso cobrá alguma coisa dele. Ele pode me falar: porque a senhora tá me cobrando, se a senhora não sabe nem lê?" (Luzia)

\subsection{3 - Relatos de situações de auxílio dos pais aos filhos na escola}

Os relatos a seguir mostram como os pais buscam auxiliar os filhos na escola, seja em trabalhos escolares, ou buscando comparecer na escola para resolver as dificuldades, seja na ajuda e cobrança para que a tarefa de casa seja feita, correção de cadernos e até no investimento em materiais educativos (livros):

"Assim, é, na semana passada eles tavam procurando um trabalho lá sobre o mosquito da dengue, num sei o que. (...) Ai eu falei, pera aí, pega o jornal que tá ali. (...) Ai chegou à tarde, ele chegou alegrinho: "Pai, você não sabe o que aconteceu". $O$ que? Um daqueles 3 recorte de jornal que o senhor me deu, me passou, a professora levou para casa dela. O $1^{\circ}$ ela leu lá na frente lá e tal.(...) Eu falei pra ele: "você acha que eu compro jornal pra que?" (Sr. Mauro)

"E férias aqui em casa, enquanto não estuda, enquanto não faz o que a gente pede pra fazer, não vai brincá, não vai assisti televisão. A gente tá sempre pegando um rumo.(...) Nós complementa.(...) Apesar deu não saber muita coisa. Mais o pouco que eu sei eu tô ali. E tá sempre ali tomando as lição deles, tá vendo as letras." (Rose)

"Igual eu falo pra elas, eu falo: "Óh, tem um canal nessa antena que ensina o dia inteiro." Eu falo: "Óh, aprende." Eu comprei um tanto de livro ali, só pra elas estudá, pra elas aprendê, pra ficá bem informada. Precisou de uma pesquisa, ali, tá ali. Vai ali, tira, estuda tudo, sabe? Mas elas não segue isso, não.” (Ilda)

"Porque eu só estudei até a $3^{a}$, então a minha mãe que ajuda ela a fazer as continhas. Vai com a avó, a avó que ajuda." (Valéria)

"Mas lógico, erro de português, quem corrige os erro de português do meu filho, quem corrige sou eu..(...) Então eu repreendo, eu chamo a atenção e eu corrijo muito os erros... Ortográficos dele porque... Passa despercebido." (Fabiana)

"Mas é tendência dela (da neta) mesma, lerda, sabe essas pessoas lerdas, desligadona. Fazia muito devagarzinho, escrevia lá. Olhava pra cá, olhava de novo. 
Ai aluno falava alguma coisa, tirava a atenção dela. Mais eu falava: Jéssica, ocê não pode fazer isso, a sua professora falou isso minha filha, presta atenção..." (D. Célia)

\title{
4.4.4 - Dificuldades que impedem os pais de acompanharem os filhos na
} escola

Nos relatos a seguir fica clara a dificuldade das mães de acompanharem de perto a vida escolar dos filhos. Elas justificam sua ausência na escola pelo excesso de trabalho, preocupações financeiras e obrigações presentes na vida familiar:

\begin{abstract}
"Às veiz, tem vezes que nem na reunião eu num posso i na escola porque é muito corrido. Eu trabaiava em restorante, trabaiava direto... Agora que eu tô trabalhando de doméstica, né? Mais é a mesma coisa.(...) Então, tem hora que a gente num tem nem parte de ficá sobre os fio da gente, né? Então, quem me carrega é aquela ali, ó. Eu deixo a casa por conta dela (a filha mais velha). Aquela de brusa azul, lá. Eu falo: "Minha fia, cê toma conta, insina ela e faz i pra escola." Porque eu não gosto que perde da aula de jeito nenhum." (Inês)
\end{abstract}

"Aí, tem dia que não dá pra mim saí, porque tem esses meninos também, né? Você sabe, vira um pé de guerra, isso aqui, ai cê vê......) Só um dia que eu larguei essa daqui, com esses, os meninos, ó, ela levou, isso aqui é ponto, ó. Aquele menino ali tacou um trem nela que cortou de fora. Eu não posso deixá sozinha com esses meninos de jeito nenhum. E meu irmão quase não fica aí. Então eu não posso saí daqui pá acompanhá elas na escola, você entendeu?(riso)" (Ilda)

"Porque eu não posso ficá 24 horas onde que eles tá, sentada, né? (...) Porque eu tenho minha obrigação. Vou lá pro fundo, fico furando pra lá, é que eu sou sozinha. Da moda do outro, minha casa só tem esse pedaço, só tem aqui, mais você tem que limpá, trazê tudo limpinho, quintal pra limpá, então ai eu procuro sabê deles, né? "Por que que cê não tá fazendo lição?", (Dona Rita)

"O pai nunca pagô pensão. Eu criei meu filho sozinha.(...) Isso reflete pra mim porque eu tenho que, que virá pai e mãe, tenho que me desdobrá pra fazê a parte financeira que o pai deveria fazê (...) Se o pai ajudasse a mãe tinha mais tranqüilidade, tinha uma vida mais tranqüila pra podê cuidá dele, pra educá, pra criá.(...) Eu acabo tendo pouco tempo tempo com ele, e quando eu tenho tempo eu tô sempre estressada, nervosa, porque eu tenho que preocupá com o dia seguinte, eu tenho que preocupá com a vida dele, a sobrevivência dele, o sustento dele, as conta, as coisa, então... É dificil." (Fabiana)

Vários entrevistados mostraram ter dificuldades em ensinar os filhos em casa, sendo que em alguns casos a justificativa é que o ensino atual é diferente daquele que tiveram. Já a Ilda colocou o desejo de voltar a estudar para ajudar as filhas. O Sr. Mauro enfatizou sua falta de tempo e paciência. A Rafaela e a Rose colocaram a importância de pedir ajuda aos professores dos filhos, buscando 
aprender a maneira "correta" de ensiná-los em casa. Já a Maria ressaltou o fato das filhas acharem que o que ela sabe é "errado". Alguns desses relatos podem ser observados a seguir:

\footnotetext{
"Agora mudou tanto o estudo que eu já nem sei o que eu te falo. Eu acho que tá difícil os pais ajudarem os filhos em casa.(...) Mudou muito as coisa." (Gisele)

"Já,(a professora) chamou porque a Lia é muito fraca. Toda reunião fala que é pra mim ajudá, que é pra mim ensiná. Só que tem um porém: a escola que eu estudei antigamente não é igual a de agora, você entende, né?(...) Falei: “Ó, não precisa nem me perguntá, porque eu não sei."(riso) Só se eu voltá estudá, né Lia?(...) Eu falei: "Ó, a hora que a mae voltá, ai a mãe ensina vocês de ponta a ponta..."” (Ilda)

"Seu pai, sua mãe te ensina, mas num tem tempo, num tem paciência." (Sr. Mauro)

"Ai ela(a professora) me ensinou o processo, é um processo longo.(...) Você tem que aprender pra poder ensinar. Cê tem que voltar a estudar, você estuda junto com eles. (risos)" (Rafaela)
}

\subsection{5 - Impotência dos pais em conseguirem que os filhos melhorem na} escola

Os pais se mostraram impotentes: por um lado, a escola cobra que eles façam algo para que os filhos melhorem e, por outro, a maneira que eles conhecem de corrigilos, que na maioria das vezes é batendo, não pode mais ser utilizada. O Sr. Mauro tenta reproduzir o discurso politicamente correto com relação aos métodos de punição, mas no final do seu relato deixa claro que os métodos antigos funcionavam melhor que os atuais. A Ilda também mostra o desejo de bater nos filhos, mas teme o Conselho Tutelar. Já a Roberta mostra que não consegue fazer com que o filho freqüente a escola, tendo medo de ser presa por esse motivo. Também a Shirley colocou que incentiva os filhos a estudarem, mas mostra-se resignada e impotente quando os filhos não correspondem. Esses relatos podem ser observados a seguir:

\footnotetext{
"A professora, a Maria. Sei que ela me chamava lá e olha o Lucas tá brincado, o Lucas num sei o que.(...) Eu falei: "eu vou lá” (...) Num era prá ir de boné, ele escondia o boné dentro da bolsa, chegava lá ele punha o boné. Eu falei: " Mas eu não mando ele vir de boné, eu não vi ele sair de boné lá de casa com boné. O que a senhora quer que eu faça? Ai eu falei, eu avisei pra ele que ele ia apanhá aqui dentro. (...) Hoje já não, se você encostá o dedo no seu filho cê vai preso. Você fica meio assim, meio no meio do caminho.(...) Tem que ir conversando. Não que o método mais rigoroso é, num sei.(D: Funcionava?) Na verdade funcionava." (Sr. Mauro)
} 
"Eu só falo assim: "Nossa, mas o que que a gente faz, então?"(...) Porque ela tem que i pra escola, no horário que tem que i, no mesmo... E não foi não, sabe? Aquela ali também, porque eu não tava em casa, só que aí, quando a gente batê, o Conselho Tutelar vem, você entendeu?" (Ilda)

"Ele chega a fazer assim comigo... Igual hoje eu levantei e falei: "Ricardo vai prá escola." Ele começou a enrolar. "Levanta, vai prá escola, arruma e sai logo prá escola, prá depois eu descer." Ele pegou o material dele saiu e foi. Eu fui trabalhar. De repente, o Ricardo de volta.(...). O Ricardo tá faltando da escola. Disse que tá dando até cadeia isso agora. Disse que se as criança tiverem faltando da escola, os pais tão respondendo processo mesmo. Eu falei pra eles: "se eles vierem atrás de mim, eu tenho os pequeno pra criar." (...) Eles tem oportunidade pra estudar, por que que não vão?" (Roberta)

"Ah é, eu incentivo eles a estudar.(...) Mas se não der mesmo, eu desanimo tamém, porque ai cê peleja com uma pessoa que não quer. É difícil, né. Porque cê manda daqui pra escola, chega na escola num quer, num vira nada. Num tem jeito." (Shirley)

Já a Dona Rita, ao lidar com um conflito entre a filha e a diretora, deixa clara sua impotência em resolver a situação e, ao mesmo tempo se sente envergonhada pela filha. A saída foi, então, tirá-la da escola:

"A Joana (filha), ela pegou a diretora e deu uns safanão na dona Sônia.(...) Essa eu tive que tirá ela. Ela era tupetuda. (...) (risos)." (Dona Rita)

\subsection{6 - Discordância entre pai e mãe}

Os relatos a seguir mostram que em algumas situações não há consenso entre pai e mãe quanto ao julgamento das situações ocorridas na escola e nem quanto às atitudes que devem ser tomadas por eles:

"Então é o seguinte, porque minha esposa fica bronquiada comigo.(...) "Eu só quero que você, como mãe, me dê uma justificativa de porque eles (filhos) levantá e pá, já ligá a TV.(...) Primeiro os deveres de casa, os afazeres escolares, domésticos. Vamo dizê assim, depois a TV. (D: Então vocêis pensam diferente?) Diferente. A nossa idéia não bate.(D: Certo, mesmo com relação a escola?) Não.(...) Porque eu falo não, ela fala sim. Ai eu já falo, então cê se vira." (Sr. Mauro)

"Pai: Essas menina tá aprendendo a falá muita bobagem na escola. Mãe: Não é, eu acho que junta com os coleguinha, entendeu? Pai: Pera ai que eu mostro a música, pera aí...(risos) Mãe: Zeca, não me mata de vergonha, não. (...)Isso dai elas aprende na rua. É lá no portão da escola." (Ilda) 


\section{5 - Compreensão dos pais quanto às dificuldades escolares dos alunos}

Nesse tópico, os relatos dos pais se enquadraram dentro das seguintes posições: apoio irrestrito à escola, a escola também pode ser responsável pelas dificuldades escolares dos alunos, ambigüidade e explicações extra-escolares para as dificuldades de aprendizagem dos filhos.

\subsection{1 - Apoio irrestrito à escola}

Alguns relatos revelaram uma clara submissão dos pais às atitudes da escola e/ ou professor. Os entrevistados enfatizaram que a escola está sempre certa, sendo todos os problemas responsabilidade dos pais ou da criança. Eles apontaram, também, que toda dificuldade escolar acontece por falta de capacidade do aluno, ou devido à maneira com que tratam as professoras. Além disso, foi colocado que quem faz o bom professor é o bom aluno. Alguns exemplos podem ser verificados a seguir:

"Se a criança não aprende... É porque é, não vai aprendê mesmo, porque eles (professores) esforçam pra criança aprendê." (Jerusa)

"Eu, se eu tenho um filho burro eu não posso culpar as professora que tá fazendo o papel dela, o trabalho dela lá.(...) Eu, pra mim, professora nenhuma teve defeito ainda." (Shirley)

"Eu acho as professora excelente, não tem reclamação. Eu sou assim, elas muitas veiz reclamava da Jéssica porque ela tava conversando demais. Eu chegava aqui e falava: Jéssica, a professora falou isso. E ela falou: ah, eu não tava lá. "Ah, tava sim, eu acredito nela e não acredito em você, cê tava fazendo sim." " (D. Célia)

"Igual a minha mãe fala: quem faz a boa professora é o bom aluno. Eu acho que se é assim um bom aluno e tudo, que procura obedecer, a professora não vai ser agressiva, não vai pegar no pé dele, né." (Sandra)

\subsection{2 - A escola também pode ser responsável pelas dificuldades escolares} dos alunos

Os aspectos que apareceram nessa categoria podem ser bem exemplificados pelas falas das seguintes mães: A Dona Rita ressaltou que todas as crianças têm capacidade de aprender e que elas não devem ser excluídas pela professora, a Carolina apontou que "nenhum aluno é burro"(sic) e que a escola é que às vezes é ruim; a Gisele 
trouxe a visão de que as crianças ficam rebeldes por falta de carinho da professora e a Inês colocou que para o aluno ser bom o professor também precisa ser bom.

"Eu acho, sei lá, dependendo da criança, ela vai muito bem. Sabendo lidá com ela, ela passa por cima daquilo ali, supera e vai pra frente.(...) Não exclui ela, por ela do lado.(...) Não é cêis separando o bom e largando o ruim pra trás.” (Dona Rita)

"É isso que é ensiná bem. É dispertá a atenção do aluno. É isso. Porque eu acho que nenhum aluno é burro.(...) Deus deu a inteligência pra todo mundo." (Carolina)

"Eu acho, às vezes, é até por falta de carinho que as criança fica rebelde do jeito que fica." (Gisele)

"Então, é isso ai que eu falo do professor. Que depende muito do professor, também, né? Que se o professor num sê bom, num tem como o aluno sê bom, também, num é verdade?" (Inês)

\subsection{3 - Ambigüidade}

Alguns pais mostraram ambigüidade no posicionamento quanto às dificuldades dos alunos. Por exemplo, o Sr. Mauro colocou que tem certeza que o filho sofre discriminação na escola, mas mesmo assim, afirmou defender sempre a escola. A Ilda mostrou críticas à professora, mas colocou que perante a filha não pode reconhecer esse fato. A Rose mostrou que não consegue achar um responsável pelos problemas que ocorrem na escola. A Carolina afirmou que a escola erra por falta de amor, mas colocou que algumas crianças também precisam de uma intervenção especializada, sendo "rebeldes" por causa da família. A Fabiana apontou inicialmente que as dificuldades das crianças têm a ver com a distância na relação professor-aluno, em seguida disse que as crianças "burrinhas"(sic) não aprendem. Alguns desses relatos podem ser observados a seguir:

"Eu num sei bem se é preconceito, num sei. (...) Que ele (filho) é santo, ele num é não.(...) É difícil falar... Eu tenho certeza que isso (preconceito) acontece (na escola), viu.(...) Eu acho, mas... (...) Eu defendo a escola." (Sr. Mauro)

"Então, ela já estudô com muitos professor bom, aí na escola. Mais é, a desse ano eu acho que num tá certo! (...) Num tá sendo bom. (...) Ela, sempre ela recrama. Eu falo: "Não, minha fia, mais vai levano." Né? Porque ninguém, também, eu num podo dexá, o minino, tudo que ele fala, cê falá assim: "Não, cê que tá, é, o professor tá certo, cê que tá errado." Né? Então ela vai estudano, estudano." (Inês) 
"Eu acho que há essa distância entre professor e aluno.(...) Cada aluno é de uma forma. Cada um tem um desenvolvimento diferente. Então, eu acho que, a, as criança tem que sê observada uma a uma.(...) Às vezes o problema é a criança, é, vô falá que a criança é burrinha, que num sabe. Ela tem uma deficiência." (Fabiana)

\subsection{4 - Explicações extra-escolares para as dificuldades de aprendizagem dos filhos}

Alguns entrevistados abordaram esse assunto mostrando tentativas de compreensão das dificuldades dos filhos. A Rafaela colocou que o filho tem dificuldade de aprendizagem por causa de problemas psíquicos com origem na primeira infância. $\mathrm{O}$ Sr. Mauro buscou um causa neurológica para justificar as dificuldades do filho. A Dona Rita atribuiu características a cada filho com relação a escola, mostrando acreditar que os problemas são individuais, desconsiderando, assim, a escola, como um aspecto importante a ser também avaliado. A Ilda mostrou que considera a filha fraca para tudo, demonstrando uma acomodação nesse conceito sobre a filha, o que justifica o fato dela não ir bem mesmo na escola. Alguns desses relatos podem ser observados a seguir:

"O Hélio é um menino meio assim, dificil. Eu num sei se já vem do problema do pai, da mãe, que já mexia com droga, essas coisas. Dizem que afeta muito, né, a criança. Ele é uma criança dificil, num tem aquela capacidade de prestá atenção." (Rafaela)

"Sinceramente de primeiro eu levava ele no médico neurologista. A coisa começa dai.(...) Eu tinha comprado uma bicicleta pra ele, ele bateu a cabeça ali em baixo, ali, tal.(...)E furou aqui, foi um problema.(...) E uma que quando ele nasceu, ele já nasceu cum cordão umbilical por pouco no pescoço, né. E já começa dai. E eu quis prová que isso atrapalhava o aprendizado dele.(...) É uma coisa que já vem lá de nascença." (Sr. Mauro)

"Agora, esse dai é meio leseiro. (...) Não gosta muito de estudá, não. (riso) Agora, a Mariana não. A Mariana, ela é uma, olha, ela entra no prezinho, ninguém ensinô ela fazê um nada, nada. Nem uma figurinha pra ela pegá no caderno eu não cortava.(...) $E$, até hoje, ela ensina essa e eu, arguma coisa que eu não sabê. Ela lê que é uma maravilha. Essa ai não sabe, assim, ela lê, mais lê meio viajando, porque essa aí não é muito de, porque essa ai é meio de, essa ai é meio aventureira.(falando da Carina)" (Dona Rita)

"É, eu acho que é, né? Aí, tanto é que ela estuda aqui, ela é fraquinha, essa menina é bem fraca. (...) Dificuldade de aprender, ela é, ela tem dificuldade pra tudo.(...) A gente coloca pra fazê lição, ela fica na mesa, ela fica, fica, você vai olhá, tá tudo sem fazê, ai já não dá tempo de fazê mais, que aí tem que i pra escola." (Ilda) 
"E a Denise, eu acho que ela é assim também por causa que ela... Eu não moro com o pai dela, né. Ela não conhece o pai dela.(...) Eu acho também assim, né. É a cabeçinha dela, ela deve pensar que todo mundo tem pai, porque eu não tenho?(...) Um pouco o que atrapalha prá ela é isso." (Valéria)

\section{Síntese dos resultados sobre o envolvimento dos pais na vida escolar dos filhos}

Esse bloco de categorias não resultou de um estímulo específico da pesquisadora aos entrevistados, mas emergiu das várias releituras das entrevistas, consistindo, assim, em categorias empíricas. Como foram muitos os relatos dos pais sobre esse aspecto, eles foram agrupados em subcategorias, apresentadas individualmente. Vale notar que os pais espontaneamente se referiram aos temas abordados nesse tópico, o que lhes dá grande relevância no contexto geral da pesquisa.

\section{Percepção sobre o tratamento recebido na escola}

O primeiro aspecto revelado foi a percepção dos pais sobre a maneira com que são tratados na escola, sendo que alguns entrevistados apontaram que existe uma abertura (especialmente por parte da diretora) para que os pais participem da escola dos filhos. Observa-se que eles deram uma conotação positiva a esse fato. Com relação ao tratamento recebido na escola, os entrevistados narraram situações em que se destacou a boa receptividade da escola para com alunos e pais, principalmente por parte da diretora. Outros pais narraram situações vividas na escola, dando uma conotação negativa ao tratamento recebido por funcionários, professores e vice-diretora.

\section{A participação dos Pais na Escola}

Os relatos sobre a participação dos pais na escola se subdividiram nos seguintes aspectos: apoio financeiro, participação em tomadas de decisão e trabalho voluntário. Alguns entrevistados relataram como é a participação dos pais em termos de apoio financeiro, narrando como fazem as campanhas para arrecadar dinheiro para a escola. 
Quanto à participação nas tomadas de decisão, algumas mães narraram como são os fóruns de discussão nos quais participam. No entanto, ao se realizar uma leitura atenta desses relatos, observa-se que não parece ocorrer realmente uma participação em tomadas de decisão.

Com relação ao trabalho voluntário na escola, duas entrevistadas narraram situações que mostram sua percepção positiva a respeito dessa prática. Vale ressaltar o relato de uma terceira mãe, que narrou como ajuda a escola, apontando que o faz não somente porque gosta, mas para que as professoras não reclamem dela. Além disso, três entrevistadas narraram suas experiências como "amigas da escola", dando uma ênfase positiva, ressaltando o vínculo positivo que construiram com os alunos.

Uma dessas mães detalhou ainda mais sua atuação, apontando aspectos negativos de sua vivência, como a crítica realizada por outras mães. Ela enfatizou, também, que percebe as dificuldades vividas pelas famílias mais carentes da escola e afirmou que essas pessoas deveriam ser tratadas pela escola com mais cuidado.

\section{Reunião de Pais e Mestres}

Com relação à reunião de pais e mestres, a maioria dos relatos (31) pode ser descrita como tendo um caráter defensivo. Esse fato pode ser verificado ao se observar as maneiras pelas quais os pais se referiram a esse assunto:

- Vários entrevistados fizeram menção ao seu comparecimento nas reuniões. Algumas mães afirmaram que sempre comparecem e outras disseram que buscam comparecer sempre que possível, enviando alguém no seu lugar no caso de uma impossibilidade. Duas mães relataram sentirem-se pressionadas pela escola para comparecerem às reuniões, sendo que uma delas se justificou por não poder ir e a outra afirmou que por causa dessa percepção, não deixa de comparecer. Ainda um relato se mostrou importante, sendo mais uma confirmação da postura defensiva desses pais diante das reuniões na escola: a mãe afirmou que nunca faltou às reuniões e, em seguida, narrou uma situação onde deixa claro que não comparece em todas elas. Além disso, quatro entrevistados colocaram que o comparecimento dos pais é importante para que possam fiscalizar os filhos.

- Alguns entrevistados somente descreveram as reuniões, sem emitir sua opinião sobre elas 
- Quatro pais fizeram uma avaliação positiva sobre as reuniões mas, ao justificarem essa opinião, acabaram por negá-la.

- Outros entrevistados criticaram, ainda, os pais que não comparecem às reuniões. Dentre eles, uma mãe se destacou ao relatar que alguns pais se afastam da escola devido às cobranças feitas a eles nas reuniões. Ela deu uma apreciação negativa à atitude desses pais.

Os oito outros relatos referentes à reunião de pais e mestres foram avaliações críticas, onde os entrevistados colocaram que as reuniões são chatas, cansativas, demoradas e geram desinteresse na maioria dos pais. Foram narradas, também, situações ocorridas nas reuniões, onde a conotação dada pelos entrevistados foi claramente negativa. Apontaram a ocorrência de preconceito, criticaram a natureza dos assuntos abordados, cuja ênfase é nas obrigações dos pais e comportamento dos alunos, além de não haver espaço para que os pais se manifestem.

O fórum instituído na escola para o encontro com as famílias não parece estar cumprindo essa função, pelo menos sob a perspectiva dos pais.

\section{Acompanhamento escolar dos filhos}

Um tema muito relevante abordado em trinta e sete relatos, foi aquele relativo ao acompanhamento escolar dos filhos. Alguns entrevistados narraram situações nas quais deixaram transparecer a percepção que possuem, de que os professores responsabilizam os pais por esse acompanhamento. Esses entrevistados mostraram concordar com essa visão. Destaca-se aqui o relato no qual o pai afirma sentir medo de que a professora pense que ele não liga para os estudos do filho.

Nessa mesma direção, alguns pais colocaram que é responsabilidade dos pais ajudarem os filhos na escola. Eles avaliaram seu papel como fundamental para o sucesso escolar.

Provavelmente defendendo-se dessa visão hegemônica, outros entrevistados narraram situações de auxílio aos filhos em várias tarefas relativas à escola, desde a ajuda em casa, até o comparecimento na escola e o investimento em material educativo. Alguns entrevistados se justificaram por não poderem cumprir bem essa tarefa. Apontaram como impecilho as dificuldades cotidianas com o trabalho e serviços domésticos e, também, a incapacidade que sentem em ensinar os filhos. 
Portanto, pode-se dizer que os pais valorizam o acompanhamento escolar dos filhos, mas sentem dificuldades em fazê-lo.

Observou-se, ainda, narrativas sobre a maneira com que os pais respondem às cobranças da escola em ajudar os filhos. Eles mostraram se sentir claramente impotentes, uma vez que o método educativo que conhecem -bater nos filhos- não pode mais ser utilizado. Diante dessa impotência (e do sentimento de vergonha, relatado por uma mãe), as seguintes alternativas foram adotadas pelos entrevistados: desistência em ajudar o filho, resignação e retirada da filha da escola.

Por fim, obtiveram-se narrações em que houve discordância entre pai e mãe quanto à maneira de compreender questões ligadas à escola. Esse aspecto confirma a proposição de Lahire (1997), já que este autor adverte a utilização genérica do termo família, como ela se fosse um sistema homogêneo. Esse autor afirma que a família deve ser entendida como posições ora complementares, ora contraditórias, que se movimentam incessantemente. Portanto, as definições rápidas e estereotipadas sobre a família, que aparecem principalmente como "rótulos", explicam muito pouco sobre o seu real funcionamento.

\section{Compreensão dos pais quanto às dificuldades escolares dos alunos}

Nessa categoria, alguns relatos apontaram uma clara submissão dos pais às atitudes dos professores. Dentre eles, três entrevistados fizeram narrativas sobre a maneira com que comunicam aos filhos o apoio irrestrito dado ao professor e à escola. Outros relatos foram avaliativos, sendo toda dificulade escolar atribuída aos alunos e aos pais.

Observa-se aqui a reprodução da lógica meritocrática, impregnada na cultura escolar. As dificuldades ocorridas são, assim, atribuídas exclusivamente a características pessoais dos alunos e familiares.

Por outro lado, alguns entrevistados avaliaram que a escola e o professor também podem ser responsáveis pelas dificuldades dos alunos.

Além disso, alguns pais apresentaram uma posição ambígua, trazendo duas opiniões contrárias num mesmo relato sobre esse assunto. Para eles, esse parece ser um tema conflituoso, já que mostraram não possuir ainda uma avaliação segura sobre ele. Por exemplo, o Sr. Mauro fez uma leve crítica à escola, favorecendo seu filho e, em seguida, mostrou apoiá-la irrestritamente. A Inês também narrou uma situação em que, 
apesar de não ter concordado com a professora, diante da filha mostrou que a apoiava. Esses pais parecem ter dificuldades em questionar a escola, defendendo-se das próprias idéias contestadoras.

Nessa mesma direção, alguns pais buscaram explicações extra-escolares para justificar as dificuldades de aprendizagem dos filhos, sendo tirados da pauta de avaliação tanto a escola quanto os professores. Esse posicionamento diante do tema pode ser descrito como defensivo, tendo sido recorrente em cinco relatos. 


\section{III - Resultados relativos às entrevistas em grupo focal}

A análise das duas entrevistas em grupo focal será apresentada da seguinte forma: será feita uma contextualização de cada encontro e em seguida virá a análise sociométrica e temática, onde serão descritas as etapas e projetos de cada sessão.

\section{1 - O Primeiro encontro}

\section{1 - Contextualização}

Inicialmente foi feito o contato com o presidente do Centro Comunitário do bairro que gentilmente cedeu o local para que fossem realizadas as reuniões do grupo. Em seguida a pesquisadora entrou em contato com cada uma das pessoas previamente entrevistadas (incluindo aquelas que passaram pela entrevista piloto) e fez o convite formal para o grupo, definindo a data e o horário.

O recrutamento para o grupo foi bem demorado porque vários entrevistados aproveitaram a oportunidade para conversar, contando um problema ou outro que estavam vivendo. Uma mãe falou do desejo de adotar um filho. Outra falou que se sente explorada pelos donos das fábricas que fazem com que ela e a família trabalhem por "preço de banana" (sic). Uma outra ainda contou dos problemas financeiros que tem vivido.

Somente três entrevistados não foram contatados porque já haviam dito que não participariam do grupo. No total de 24 pessoas, 18 confirmaram presença, mas somente 8 efetivamente compareceram. Duas mães telefonaram para a pesquisadora avisando que não poderiam ir, sendo que uma delas acabou fazendo um esforço e conseguiu comparecer.

No dia do encontro, as três primeiras mães que a pesquisadora foi buscar em casa não estavam presentes, tendo deixado recado com os filhos que não teriam condições de comparecer: uma por motivo de trabalho, outra por ter que tomar conta do neto e outra porque o marido não a deixou participar. A pesquisadora já imaginava que o grupo não iria acontecer, mas a quarta mãe, a Valéria, já estava esperando na porta de casa. Ela estava tão animada que reanimou a pesquisadora. O próximo a ser pego foi o Sr. Mauro e, na porta de sua casa, um rapaz dependurou-se no vidro do carro, olhando 
para dentro, como que sondando. Em seguida, fez um Ok com a mão e saiu. A Valéria disse que ele estava envolvido com tráfico de drogas ${ }^{13}$. Logo em seguida, o Sr. Mauro saiu de casa e entrou no carro. A Rafaela também estava pronta e a Carolina disse que iria depois a pé. A última a ser pega foi a Gisele. Até o horário marcado para iniciar a sessão, somente esses quatro participantes estavam no centro comunitário: Valéria, Sr. Mauro, Rafaela e Gisele. Em seguida chegou a Rose (que havia ligado no mesmo dia para a pesquisadora falando das dificuldades que teria para comparecer) e a Maria, que veio a pé. A Cibele e a Carolina chegaram mais tarde um pouco, com o grupo já em andamento.

A sessão grupal aconteceu em três etapas, como usualmente acontece em grupos de referencial psicodramático. O aquecimento, que se caracterizou pela apresentação, contrato e preparação do grupo para que entrasse no tema de forma mais espontânea; o desenvolvimento, onde ocorreu a discussão verbal sobre temas ligados à escola. Por fim, na etapa de comentários, as pessoas fizeram uma avaliação da experiência vivida, compartilhando as impressões com os outros integrantes do grupo.

O grupo iniciou-se às 19:15h e terminou por volta de 21:15h. Depois do encontro os participantes ainda ficaram no centro comunitário até 22:30h, conversando e comendo o lanche levado pela pesquisadora. Alguns foram indo embora e ficaram por último a Valéria, a Rafaela, a Gisele, o Sr. Mauro e a Rose. Foi a pesquisadora quem tomou a iniciativa de ir ajeitando as coisas para ir embora. Os participantes do grupo pareciam estar bem à vontade, "jogando conversa fora" como se já se conhecessem há muito tempo. O mesmo clima de intimidade aconteceu entre os participantes e a pesquisadora, sendo que esses procuravam incluí-la na conversa, fazendo perguntas sobre sua vida pessoal. Nesse momento, eles colocaram que o grupo foi bom para espairecer, que eles estavam se sentindo mais relaxados e que gostariam de participar de outros encontros como esse. Uma das participantes perguntou se poderia trazer o marido no próximo encontro e outra perguntou se poderia trazer a mãe. Apesar do clima descontraído, o Sr. Mauro e a Valéria pareceram estar um pouco mais retraídos que os outros integrantes nessa etapa final.

De maneira geral, o grupo pareceu ter se soltado, tendo o encontro atingido seu objetivo, que era revelar aspectos da relação dos pais com a escola, que não haviam sido

\footnotetext{
${ }^{13}$ Em outubro de 2004, quando a pesquisadora voltou ao bairro para fotografá-lo, foi informada que esse rapaz, enteado do Sr. Mauro, havia falecido com um tiro na cabeça. Todos da família estavam muito abalados.
} 
abordados nas entrevistas individuais. Vale notar que a Carolina não se integrou ao grupo porque saiu muito cedo e a Valéria, apesar de ter sido a mais calada, mostrou ter aproveitado muito a sessão. Quando a pesquisadora foi levá-la de volta em casa, essa impressão foi confirmada, já que ela espontaneamente comentou que aproveitou muito o encontro, dizendo que os que não compareceram foram 'bobos' (sic).

\section{2 - Análise sociométrica e temática}

O primeiro encontro foi subdividido em três etapas: Aquecimento, Desenvolvimento e Comentários, como pode ser observado a seguir.

\section{Etapa 1: Aquecimento}

Essa primeira etapa teve por objetivo preparar o grupo, buscando flexibilizar as questões sociométricas, para que ocorresse um clima de liberdade onde cada um pudesse verdadeiramente expressar seus pensamentos e sentimentos. Buscou-se também mobilizar o grupo para que o tema fosse discutido nessa etapa de forma espontânea. A fase de aquecimento constou de três projetos: Projeto 1- Apresentação e contrato, Projeto 2- Aquecimento inespecífico, Projeto 3 - Aquecimento específico. Em todos esses projetos a coordenadora do grupo (pesquisadora) foi a protagonista, uma vez que o grupo foi dirigido através de jogos dramáticos, até que fosse deixado livre no momento da discussão. No primeiro projeto, o grupo funcionou numa relação de parceria com a coordenadora, não havendo nenhum antagonismo. No segundo e terceiro projetos, a Gisele se colocou inicialmente como antagonista à proposta da coordenadora, mas logo cedeu. A Carolina também se destacou no segundo projeto por estar muito agitada, querendo sair do grupo, tendo dificuldade de se integrar. As análises dos três projetos grupais presentes na etapa de aquecimento podem ser verificadas a seguir:

\section{Projeto 1 - Apresentação e contrato}

Na primeira parte do encontro, a coordenadora buscou integrar o grupo e tornar favorável a sociometria para que o grupo acontecesse de fato e as pessoas ficassem à vontade para falar. Após o contrato e apresentação, foi realizado um jogo sociométrico 
onde as pessoas deveriam se posicionar na sala de acordo com perguntas feitas pela coordenadora. Por exemplo, quem conhecesse só uma pessoa deveria se posicionar em um dos cantos da sala, quem conhecesse duas pessoas deveria se posicionar em outro canto e assim por diante. Dessa forma, as pessoas iam caminhando e visualizando suas posições na sala, conhecendo-se um pouco mais. Foi perguntado, também, a respeito do número de filhos, tempo de moradia no bairro, tempo de contato com a escola, entre outros. Essa atividade descontraiu bem o grupo, os participantes falaram, fizeram brincadeiras uns com os outros e riram bastante.

\section{Projeto 2 - Aquecimento inespecífico}

A coordenadora propôs uma fantasia dirigida em que os participantes deveriam caminhar pela sala imaginando que estavam indo para a sua própria escola. Eles deveriam, nesse momento, imaginar o percurso, lembrar da escola, dos professores e do que mais lhes viesse à mente. $\mathrm{O}$ objetivo era resgatar as emoções ligadas as suas vidas escolares. Em seguida eles se juntaram em duplas e conversaram sobre o que lembraram. Depois cada um contou o que ouviu do parceiro para o grupo todo. Foi também um momento descontraído, onde as pessoas riram muito das histórias contadas. A única pessoa que pareceu não se integrar muito foi a Carolina, que estava ansiosa porque iria sair mais cedo do grupo para encontrar o namorado. A Gisele, que mostrou resistência à proposta num primeiro momento, talvez o tenha feito por ter lembranças tristes da escola, como ela própria relata:

Gisele: Aquela poeirada... (...) Foi muito triste minha $1^{a}$ série. Num quero lembrar disso não... A professora era velhinha...

No momento de apresentação para o grupo todo, a Carolina se mostrou numa postura antagonista aos demais, se mexendo na cadeira e cochichando com a colega. Os outros participantes escutaram atentos as histórias contadas por cada um, as quais podem ser observadas a seguir:

Cibele: Ah, eu ouvi que ela (Carolina) era extrovertida na escola, participativa, né. E o diretor dela era bravo. Ela sempre ia de castigo pra diretoria. (risos)

Carolina: Agora ela (Cibele) já era o contrário. Era introvertida. A professora era brava.(risos) (...) A escola dela era grande e a diretora boazinha. Ah e nóis tinha 
alguma coisa em comum: o inspetor da escola dela era careca o meu também era careca. (risos)

Valéria: Ela (Maria) era muito estudiosa e gostava quando tinha festinha.

Maria: Ela (Valéria) também era muito estudiosa, gostava muito da escola.(..) Ela num podia levar lanche e sempre ficava com vontade do lanche dos colegas... (risos) Era pão com mortadela e até hoje ela é apaixonada... (risos) (Várias pessoas falando aо mesmo tempo)

Rafaela: O Sr. Mauro gostava de ir na escola e num tinha pai e mãe pra levar. Pra acompanhar, né.(...) Ia sozinho.(...) Uma coisa que ele gostava muito era usar uniforme, né?(...) Naquela época ele tinha orgulho, né, de por uniforme todo arrumadinho.

Sr. Mauro: Eu tinha que estudar sozinho. Minha mãe ia me ensinar o que ela não sabia? E num aprendia pra ver não.(...) Ela (Rafaela) gostava de estudar, né. Ela disse que veio da roça.

Gisele: Ela (Rose) falou que a escola que ela estudava era muito bonita. Ainda mais depois que eu descobri que ela era lá na minha cidade, era mais bonita ainda... (risos) Ela me falou que ela era muito tímida, mas gostava muito de estudar.(...) Por ela ser tímida, ela ficava mais era sozinha.(...) Ela gostava de tomar lanche de baixo de uma seringueira.(...) A minha você não fala não (se dirigindo à Rose).

Rose: A professora dela (da Gisele) já era de idade, muito chata, rígida. Ela num gosta nem de lembrar... (Risos- Pessoas falando ao mesmo tempo)(...) Cada erro era um puxão de cabelo. (risos)

O relato sobre a Gisele desencadeou um assunto referente às professoras de hoje e de antigamente, sendo que, apesar da postura rígida e agressiva, o Sr. Mauro colocou que gostaria que o filho tivesse uma professora como as de antigamente. A Gisele acabou concordando com ele:

Mauro: Mais por outro lado eu gostaria de uma professora dessa para o meu garoto.

Gisele: No começo eu num sabia, eu morria de medo dela. Só que depois eu aprendi, assim, que ela era daquele jeito, num era porque ela era ruim. Ela era uma professora enérgica e exige realmente.(..) E eu acho que hoje em dia o que falta é professoras assim, também, igual ela era.

\section{Projeto 3 - Aquecimento específico}

A coordenadora pediu que os integrantes do grupo caminhassem novamente pela sala, só que dessa vez imaginando que estavam levando os filhos para a escola. Eles deveriam imaginar a cena de chegada, observar os sentimentos decorrentes desse 
momento e deixar vir à mente tudo que tinha relação com a escola do(a) filho(a). Cada um deveria parar de caminhar quando realmente conseguisse entrar em contato com a escola dentro de si. Nesse momento, a coordenadora pediu que cada um dissesse uma palavra que simbolizasse o que estavam sentindo. Os participantes não falaram de sentimentos, mas o que diriam aos filhos quando esses fossem deixados na escola. Como o objetivo aqui era que o grupo se subdividisse sociometricamente, a coordenadora não se preocupou com o conteúdo das falas e pediu que cada um se aproximasse da pessoa cuja palavra mais se assemelhasse a sua própria palavra. Formaram-se, então, três subgrupos e cada um deveria conversar sobre a escola do filho. Os subgrupos formados foram:

- Rafaela, Maria e Cibele: falaram bem da organização e da confiança que possuem na escola.

- Gisele e Carolina: falaram positivamente sobre a organização e disciplina da escola.

- Rose, Sr. Mauro e Valéria: falaram sobre a organização, limpeza e carinho da escola para com os filhos. Colocaram que não têm reclamação da escola e que os pais ajudam muito lá, e que ela não é só das professoras e da coordenadora, mas também dos pais.

Vale notar que a Carolina e a Gisele ficaram juntas, o que faz sentido se for observado o fato de que as duas já haviam se colocado explicitamente como antagonistas aos projetos do grupo.

Outro aspecto importante é que os participantes do grupo conversaram muito rapidamente sobre a escola, mostrando não terem conseguido nenhum aprofundamento sobre o tema. Quando contaram o que conversaram para o grupo todo, o fizeram na maioria das vezes com poucas palavras, fechando rapidamente o assunto. Falaram mais da organização, de coisas superficiais e positivas.

\section{Etapa 2: Desenvolvimento}

Essa etapa tratou do tema propriamente dito, tendo ocorrido discussões verbais acerca de assuntos relacionados à escola. O primeiro projeto dessa etapa foi a resistência a se expor por parte dos integrantes do grupo, ou jogo de esconderijo, como é denominado por Milan (1976), quando as pessoas buscam se esconder da tarefa 
proposta, colocando um claro antagonismo ao que foi pedido pela coordenadora, que era conversar com intimidade e autenticidade sobre a escola dos filhos.

\section{Projeto 1 - Resistência a se expor}

Esse projeto do grupo se caracterizou por dois momentos:

$1^{\circ}$ Momento: Esse momento pode ser descrito como fuga do tema, onde todos os participantes respondiam às perguntas com poucas palavras e superficialmente. Esse movimento do grupo durou enquanto a coordenadora se esforçava para levantar as críticas e questões mais profundas, sendo portanto a protagonista desse momento, tendo como antagonistas todos os participantes do grupo. Formaram-se, assim, duas unidades sociométricas: uma composta pela coordenadora e outra composta pelos integrantes do grupo. Esse momento do grupo pode ser ilustrado pelas seguintes falas:

Daniela: Então gente, ceis colocaram a organização, limpeza, comunidade participante, confiança de que os filhos estão em segurança... É isso?

Rose: O amor e o carinho, né? Isso tudo ajuda.

Daniela: $O$ amor e o carinho. Certo. Tem mais alguma idéia que vem a respeito disso? Ou alguma outra idéia? (Silêncio curto) (...) Todo mundo concorda com essas coisas que vocês colocaram? (Silêncio curto)

Rafaela: Respeito.

$2^{\circ}$ Momento: $\mathrm{O}$ segundo momento teve como característica o esboço de uma crítica levantada pelo Sr. Mauro, movimento que foi rapidamente abafado, especialmente pela Gisele, que é "amiga da escola" e que tomou sua defesa. Observa-se que o Sr. Mauro pareceu buscar uma aliança com a coordenadora trazendo sua questão, mas o grupo não permitiu que isso ocorresse: a Gisele mudou o assunto e o grupo a seguiu. As unidades sociométricas ainda estavam formadas da mesma maneira: de um lado a coordenadora e do outro os integrantes do grupo. Alguns desses relatos podem ser observados a seguir:

Mauro: Igual o meu garoto que é fogo na roupa. Eu sei que ninguém segura ele. Então isso ai apronta uma bagunça, né. E ninguém percebe como ele pode melhorá na escola.(...) Ele não é bobo. Ele quer fazer basquete, conseguiu uma bolsa, mas eu não consegui trocar o horário dele na escola.(...) Consegui nada. É sempre assim. Quem vai resolver? Não é obrigação do governo.(...) Então eu não posso fazê nada. Não tem como arrumar isso prá ele. Prá ele i pro basquete. Mais ele qué. 
Gisele: Tô vendo o senhor falar, tô lembrando dele, só tô vendo ele na minha cabeça. Eu falo muito isso pra ele. "Eu tô de olho em, você, hein, Lucas?" Ele responde: "Tia, mais só tem eu aqui?" Agora ele deu de jogar figurinha. Ele tá bem mais calmo lá na hora do recreio. Mais é engraçado, tô escutando ele falar (se refere ao Sr. Mauro) vendo ele, porque o ano passado realmente ele deu muito trabalho.

Mauro: Meu Deus do céu.

Gisele: E esse ano não, entendeu? Esse ano ele tá mais calmo.(...) Eu acho que com carinho as criança ali tá melhorando. Porque quando eu comecei (a ser amiga da escola) elas eram muito mais agressivas. É claro que tem um caso isolado. Um ou outro. Mais hoje em dia, no caso do dela (se refere à Rafaela), que tá na classe do meu, ele também é danadinho.(...) Mas, por exemplo, desde que a D. Sônia tem carinho com os pais, com os alunos, tudo, ela passa isso para os funcionários dela e para nós que tamo ajudando ela, entendeu?(...) Igual o dele (se referindo ao filho do senhor Mauro). Mais esse ano ele melhorou demais, eu num tô vendo ele correr com os outros colega dentro da escola. (...) Ele gostava muito de pular, sabe, aquela arquibancada que tem lá na escola, tinha uma mureta. E de pular lá em baixo na quadra, assim, dava um mortal, assim, e pulava. Eu falei: "Lucas, cê vai quebrar a cabeça, menino." O ano passado foi isso. Esse ano eu num vi ele fazer isso não.

\section{Projeto 2 - Quebra da resistência a se expor}

Dessa vez foi a Rose quem trouxe uma crítica de que a diretora deveria deixar as crianças levarem brinquedos para a escola, para a hora do recreio. Apesar da Gisele tomar mais uma vez a defesa da escola, o grupo embarcou na proposta da Rose e, por fim a Gisele também saiu do antagonismo. As unidades sociométricas se caracterizaram por um breve momento da seguinte forma: Rose + Outros participantes do grupo (críticas à escola) versus Gisele (defesa da escola). Vale notar que nesse momento a coordenadora tinha buscado conscientemente sair do protagonismo. $\mathrm{O}$ sentimento que a invadiu foi de desistência da posição de puxar o grupo. Quando isso ocorreu, a Rose tomou para si essa função e o grupo a seguiu. A ver:

Rose: E também criança gosta de brincar com figurinha, com tazo. Ai a Dona Sônia achou que tava virando muita bagunça. Cê vê, se num deixa eles brincar cum nada, eles num tem o que fazer. Vai ficar correndo, vai virar bagunça. Poderia deixar os menino brincar assim, com uma figurinha, com tazo. Mas que pusesse uma ordem. Vai brincar, mas se virar briga não vai brincar mais. E ela proibiu isso aí, não quer figurinha, não quer tazo.

Gisele: É porque eles brigam direto por causa disso...

Daniela: Então vamo ouvir um pouquinho mais isso aí. Eu acho importante. 
Rose: Seria bom se ela deixar eles levar algo pra brincar. Porque senão vira uma rotina. Todo dia: "Vou brincar de quê?" Levar algo pras criança brincar.

Daniela: Você tá falando que se não tem nada pra brincar pode acabar virando confusão, porque não tem nenhuma atividade?

Gisele: Mais eu tô lá, eu sei como é que é. Tem deixado. Eles levaro bolinha de gude pra brincar. Tomaram dos meninos porque tava brigando. E eles tomam. Mas no fim da aula devolve porque eles ficam triste porque tomou, entendeu? A Mirtes(vice diretora) não abre mão de nada não, ela toma e não deixa devolver... Que nem tinha um menino lá que tava lá no maior sossego jogando peão. Aí foram e tomaram o peão dele. Ele chorou e pediu pra mim.(...) Então, eu acho que isso lá também, é igual cê tava falando (se referindo a Rose). Eu que tô lá eu vejo. Tem que deixar eles brincar de alguma coisa pra eles dá um pouquinho mais de sossego. Até pra gente mesmo. E pra isso, igual, tem muitos lá que forma grupinho de 4, leva baralho e joga truco. Tirar deles é uma violência.

Observa-se nessa última fala da Gisele, a maneira como ela saiu do antagonismo, mudando claramente de opinião.

\section{Projeto 3 - Críticas à escola}

$1^{\circ}$ Momento: Daí em diante, a Gisele, a Maria, a Cibele e o Sr. Mauro apoiaram a crítica da Rose, relatando fatos semelhantes ao seu. A discussão no grupo começou a fluir, não ocorrendo mais somente as frases curtas e conclusivas. Esse momento do grupo pode ser ilustrado pelos seguintes relatos:

Maria: Eu acho que às vezes pega o brinquedo né... Gera violência porque, cê vê que, esses ataques de lá nos Estados Unidos. É tudo gerado violência dentro da escola. A diretora não pode tirar as coisas deles assim.

Cibele: Eu concordo porque se é uma coisa que a criança leva pra escola é porque é uma coisa que ela tem carinho. É um brinquedo que ela se apegou.

Rose: Eu acho que tem que explicar desde a hora que sair a primeira briga. E falar: "Não vai trazer mais." Ai eles vão respeitar...

Mauro: A gente tem que comprar prá eles e eles já qué levá.

Rose: Aí a diretora: "Não não pode." Então ela tá tirando o direito da criança brincar.

$2^{\circ}$ Momento: Um outro tema discutido pelo grupo, especialmente pela Maria, Rose e Cibele foi a violência que ocorre na escola. Nesse momento não houve uma relação antagônica e o grupo funcionou mais numa relação de parceria, o que caracterizou toda 
a duração do atual projeto. Os relatos iniciaram tratando da violência contra os alunos e terminaram com a violência contra os pais também, como pode ser visto a seguir:

Maria: Porque tem certos professores que já partem pra violência. Rasga a folha do caderno, né, perto dos outros alunos. Eu acho que isso gera violência. Não pode. Os professores precisa ter uma, assim, educação melhor.

Rose: O meu menino já é rapazinho, cê vê. Vá lá, tudo bem que a escola proíbe. $O$ meu menino levou (baralho) porque os outros amiguinhos pediu pra jogar no recreio.(...) De repente: "Vamos levar pra diretoria." Levou o menino lá e fez aquele escândalo.(...) Só porque ele trouxe baralho. Devia ter chamado ele lá e conversado com ele sozinho. Mas não. Ela chegou já desabando.

Cibele: Existe isso. Mas aí nessa escola não é só com os alunos não, é com os pais também.

Rose: Então, mas isso não pode.

Cibele: Já, já me chamaram atenção na frente dos pais e eu não gosto. Isso eu acho errado. E não é só a minha não, de muitos pais. Chamam atenção e isso é humilhante, eu acho isso humilhante tanto pra criança quanto prá nós.

$3^{\circ}$ Momento: A Cibele, a Rose, a Gisele (mesmo que de maneira ambígua) e a Maria fizeram críticas à vice-diretora, pela maneira como lida com as questões na escola. Elas colocaram, ainda, que existe uma diferença no tratamento de uns e de outros dentro da escola, não havendo um padrão geral. A Gisele ainda narrou de uma situação em que a vice-diretora mandou dois alunos tirarem os brincos, não permitindo que eles os usassem na escola. Essas falas podem ser verificadas a seguir:

Rose: O Gustavo não gosta nem que fala na Mirtes (vice diretora).

Cibele: O meu também não gosta.

Rose: É o tal negócio, ela chega assim babando, ela é um amor de pessoa pra conversar com a gente, mas com os alunos...

Gisele: Ela que põe ordem na escola...

Cibele: Se ela quer chamar atenção dos pais, chama lá num canto. Não é assim. As crianças também, não tem que humilhar na frente dos outros.(...) A minha (filha) é uma manteiga. (...) Às vezes, igual a Mirtes chamou atenção dela, ela derrete.

Rose: O Gustavo não gosta que fala dela. Ele fala: "Se tem alguém fazendo coisa errada, ela culpa eu. Ela olha em mim e fala: é o Gustavo."

Gisele: Tem certas criança que é mais problemática que as outras. Ai tudo o que acontece é os problemático... "Ah, eu sabia que era você." E às vezes nem num é.(...) 
Porque isso aí, até eu que sou mais de idade, morro de medo da Mirtes.(...) Ela tem muita disciplina dentro da escola.(...) O dia que ela tá na escola, o andamento da escola é outro. O que ela não tá, o circo pega fogo.

Rafaela: Eu inventei de perguntar pra ela se eu podia ajudar no recreio depois que eu tive meu menino.(...) Porque ele tem 2 anos. Eu vou deixar com quem? Eu podia levar ele e ficar lá comigo, mas ela falou que não.

Maria: A Sônia é outra coisa. Os problemas que eu tô precisando resolver, é só com a Sônia. Até essa que tá na $5^{a}$ série, eu resolvo só com a Sônia. A Mirtes não dá.

Gisele: A Mirtes manda na Sônia também.

Rose: $O$ dia que tem inglês pode ir com o uniforme, aquela camiseta do inglês. Se ela vê o Gustavo ela já reclama que ele tá sem uniforme da escola. Parece que ela marcou o meu menino(...) "Eu já te falei, não deixa eu te pegar sem uniforme de novo. Vem com o seu uniforme do seu inglês por baixo e o uniforme (da escola) em cima". Então não pede pra fazer uniforme.

Rafaela: O problema é que as crianças não tem respeito, tem medo.(...) Acho que a pessoa tem que dá o respeito e não medo. Ai eles respeita ela.

Gisele: Apareceu um caso lá de que tem dois meninos lá na quarta série que furou a orelha esse final de semana.(...) Ela pegou e fez o menino tirar o brinco.(...) E não sei quem foi lá tirar o brinco do outro, começou a sangrar, desse menino. Uma menina foi lá e falou: "Olha o que a Mirtes fez na orelha do menino." Ah, se você vê ela gritar no pátio, falando que ela não tinha feito nada daquilo e que não era aquilo? (...) E é aquilo mesmo que ela falou, as crianças não tem respeito, é medo.

$4^{\mathrm{O}}$ Momento: A Gisele, a Rafaela e a Rose fizeram críticas às professoras, como pode ser visto nos seus relatos:

Gisele: Ela (professora) pegou e falou assim: Se for prá deixar os meninos com a cuca queimada você me dá que eu quero dar para eles também, eu quero fazer esses meninos sofrer, eu quero ver quem é bom e quem não é. E falou e olhou prá mim. Porque o meu menino até hoje não me deu problema na escola, entendeu? Ele nunca tirou nota baixa, não me dá problema, ele faz a lição direitinho. Só que ele tá assim, esse ano ele tá terrivel, ele não quer fazer lição, ele chega e: "que professora chata, que não sei o quê."

(Várias pessoas falando ao mesmo tempo)

Rafaela: Esses dias ela falou pro Hélio (filho): "olha o caderno do Caio (filho da Gisele) como tá bonitinho, você não tem vergonha?"

Rose: Por que gritá com os alunos: "cala a boca!"? Então você vê que ela tá ali estressada e passando uma energia negativa pro aluno. Não pode.

$5^{\circ}$ Momento: $\mathrm{O}$ tema discutido nesse momento foi a necessidade de respeito mútuo entre a escola e o aluno, tendo como principal protagonista a Maria, que contou com o apoio especialmente da Cibele e da Gisele, como pode ser visto a seguir: 
Maria: Eu tenho uma menina na $4^{a}$ série e ela chega em casa sempre reclamando. "Mãe ela falou: "Mãe a professora só grita." (Várias pessoas falando ao mesmo tempo)(...) Ela tem que mudar esse método ai de ensino. Isso tá errado, as crianças num aprende.

Gisele: Parece que elas (professoras) perderam o interesse, tão desmotivando eles mais ainda.(...) E agora elas não tá conseguindo contornar a bagunça dentro da classe.

Maria: Você vê que tá faltando o que, né? É ver também o lado do aluno. Aí ele respeita a escola.

Cibele: Isso é importante.

\section{Etapa 3: Comentários}

Apesar do grupo estar muito aquecido, a coordenadora iniciou o fechamento da sessão devido ao horário. Mesmo assim a sessão ainda continuou por um bom tempo, tendo ocorrido nessa etapa o protagonismo mais importante do atual encontro, o do Sr, Mauro, como pode ser visto a seguir.

\section{Projeto 1 - Retomada do Contrato do Grupo}

Nesse projeto, o grupo se voltou ao questionamento do que seria feito com as informações obtidas ali, pedindo para a coordenadora intervir diretamente na escola. Essa questão foi levantada pela Rafaela, Cibele e Maria, que tiveram o apoio do restante do grupo. Essa foi uma unidade sociométrica em oposição à coordenadora, que foi solicitada a colocar como a devolutiva seria feita, reafirmando o contrato. Esse projeto pode ser ilustrado pelos seguintes relatos:

Rose: Deixa eu falar, isso tudo que a gente tá conversando aqui, você vai comentar com ela (diretora)? (Carro passando)(Várias pessoas falando ao mesmo tempo)

Daniela: Não.(...) Nós não vamos apontar ninguém.

Cibele: Seria bom (que comentasse).

Daniela: Nós vamos entregar o trabalho pra ela, esse é meu compromisso.

Maria: Ah, entregá só pra escola?

Daniela: Não aí depois nós vamos publicar isso como uma pesquisa realizada com pais de crianças da escola. Vamos publicar em revista cientifica. Teve uma mãe que 
deu a idéia de estar mandando pra secretaria da educação. Ai a gente vai ver o que pode fazer.

Maria: Tudo o que a gente falou no individual também vai ser?

Daniela: Vai também aparecer.

Projeto 2 - Relato de uma situação pessoal - protagonismo grupal

O Sr. Mauro iniciou um questionamento da escola de maneira bem tímida, apesar de deixar transparecer o sofrimento que vinha tendo por esse motivo. Ele se queixou de uma situação em que o filho não entrou na escola por causa do uniforme, enquanto outras crianças, também sem uniforme, permaneceram na escola. Com a resposta da Gisele, seu relato ganhou uma legitimidade que ele não parecia atribuir à primeira queixa, chegando à conclusão de que havia discriminação na escola. $\mathrm{O}$ grupo se mobilizou com essa questão e principalmente a Gisele, a Rose e a Rafaela o apoiaram. A Rafaela também relatou uma situação pessoal. Talvez, esse momento tenha sido o de maior emoção no grupo, quando as pessoas pareceram perceber uma situação real e sofrida que vinha ocorrendo no interior da escola. No entanto, como não havia mais tempo, esse projeto não se pôde se estender o quanto o grupo parecia desejar. Os relatos ilustrativos desse momento podem ser verificados a seguir:

Mauro: Eu ia fazer uma pergunta indireta, vamos dizer assim.

Daniela: Certo. Pra mim?

Mauro: Não, pra quem quiser responder. Será que todos os alunos vão à escola uniformizados, todos eles?

Rose: Pelo menos o meu vai.(Várias pessoas falando ao mesmo tempo)

Gisele: A maioria vai.(...)(Várias pessoas falando ao mesmo tempo)

Daniela: E o senhor, Sr. Mauro, o que o senhor. pensa?

Mauro: Sabe por qual motivo que eu vim pra essa reunião? Aquele dia que nóis conversamo (se referindo à pesquisadora), no outro dia desceu um menino sem uniforme. O Lucas(filho) não vai entrar(na escola). Tudo bem. Fui na escola. Cheguei lá: "ela não tá, mais tarde você passa aqui." Mas eu não posso, eu tenho perícia.(...) Eles falaro prá eu vir aqui.(...) Marcaro às duas horas, pra atender.(...) Ninguérm chegou. Eu fui no INPS e assim que eu sai do INPS eu passei aqui.(...) Igual, o menino(filho) chegou lá (na escola) e ela (vice-diretora) não deixou ele entrar. $O$ porque eu não sei, o que era.(...) Não, no terceiro dia eu fui lá: "Ah, você só vai voltar aqui 5:30 da tarde, tudo bem?" E não tem ninguém que vai vir mudar. Acabou, acabou. Ai só depois de quatro, cinco dias que a gente conseguiu se encontrar (ele e a vice-diretora). Quer dizer, esses dias tudo ele (filho) perdeu aula. Ele pode ser bagunceiro, seja lá o que seja. Mas ele perdeu aula e um dia isso vai vir a tona. (...) 
Fiquei lá esperando duas horas. Fui embora. É brincadeira?(...) Agora eu vou voltar aqui de novo 5:30 da tarde? "Você vai me desculpar mais eu não vou voltar aqui não."(...) Então, como eu estou afastado (do trabalho), eu tô sentado no portão da minha casa, eu vejo um passá com uma calça verde, outra assim, assado. E por que só o meu não entra na escola? Então você vai ter que me provar porque? Eu sei.(...) Os outro (alunos sem uniforme) não voltou. E o meu tá assim, perdendo aula. Eu fiquei cismado. Eu tenho que ir na escola e fico lá esperando...

Gisele: Deixa eu te falar uma coisa. É igual ela falou a Rose, é a tal da discriminação. Assim, eu quero dizer assim, no caso que começa a taxar muito só um, você entendeu? E aí o ano passado ele deu muito problema pra escola. Se esse ano ele aprontar, ou vier sem uniforme prá escola ele vai ser crucificado.(...) Porque tem muita criança na escola sem uniforme e que passa desapercebido.(...) Só os mais danadinho que elas (na escola) pega, porque eles destaca.(...) É, igual o Jair da classe do meu menino também. Hoje ele foi sem uniforme. Ah já mandaram ele pra diretoria. Mas gente por que? Porque ele também o ano passado deu muito trabalho. (...) Mais não é só ele, tem muita gente aqui na escola que tá sem uniforme.(...) Esse negócio de pegar um ou dois no meio daquele tanto de aluno não dá certo. (Várias pessoas falando ao mesmo tempo)

Mauro: Eu pra ser sincero, eu escrevi lá assim: "Existe discriminação sim."(...) E bati o martelo.

Gisele: É, mais existe mesmo, você entendeu? Porque eu vejo. Porque tem um ou outro lá que é taxado como danado.

Rafaela: Isso acontece com o meu também. Ele dá problema, ele não presta atenção, se passar um mosquitinho, ele vai acompanhando o mosquito até lá no fundo.

\section{Projeto 3 - Reflexões sobre o grupo}

Esse projeto se caracterizou pela avaliação sobre a experiência vivida no grupo e os sentimentos decorrentes dessa vivência. Todos os integrantes participaram da avaliação, mostrando um vínculo de parceria com a coordenadora, que havia feito a proposta:

Cibele: Eu me senti descontraída, bem à vontade.

Rafaela: Eu tô me sentindo muito bem, nessa conversa com o pessoal aqui, né. A gente vai expondo as idéias. Mais foi ótimo, eu acho que eu nunca tive participado assim com o pessoal.

Gisele: Tem hora que a gente fala assim: "Vai lá e dá um medo assim." O que será que eu vou falar? Acho que não vou falar nada não. (risos) Mais ai a hora que chega a gente se solta. A gente vê que tem problemas igual os da gente. Todo mundo conversa e chega a uma conclusão.(...) Mais aqui eu achei que foi muito gostoso. (Barulho de carro passando) 
Maria: Eu gostei demais, se tiver outra é bom, porque eu espero que tenha valido a pena sim, né. E que tenha mudança.

Valéria: Eu me senti à vontade, gostei e quero que continue. (Várias pessoas falando ao mesmo tempo)

Mauro: Eu também, foi bom mesmo.(...) Através daqui, assim, descobri novas idéias, alguns problemas. Solucionar os problemas. Seria de maior esforço prá chegar e entender. Isso, isso será que é preciso mais reuniões prá ver os problemas?

Gisele: Soluções também nóis vamos encontrá. (risos)

Mauro: Através assim de maior esforço pra chegar na secretaria, na onde for preciso, com mais certeza, com opinião. Isso será que é possível?

Daniela: O Sr. tá pensando nas soluções?

Mauro: Exato.(Várias pessoas falando ao mesmo tempo)

Rose: Eu gostei daqui. E nóis vamo conseguir.(...) Então eu acho que nóis deveria marcar outra reunião, sei lá.(...) As vezes não sugiram tantas idéias. Mais aí a outra reunião vai ter mais ainda, você vai ver.

Cibele: Falamos por todos que não vieram.

\section{Projeto 4 - Negociação do próximo encontro}

Para finalizar, a coordenadora propôs que se discutisse se haveria ou não um próximo encontro do grupo, tendo sido unânime a resposta de que haveria essa necessidade. Todos mostraram o desejo de participar e buscaram uma data em que nenhum integrante ficaria de fora por não poder comparecer. $\mathrm{O}$ encontro seguinte ficou agendado para daí a quinze dias.

\section{O movimento do grupo - síntese do primeiro encontro}

Logo após o aquecimento, observa-se que o Sr. Mauro já tentava trazer a sua questão, levantando o assunto da discriminação do filho, tema protagonista do grupo. No entanto, nesse momento o grupo estava num outro movimento, o de negar e esconder qualquer protagonismo, escondendo-se do desejo da coordenadora, de que o grupo produzisse e deixasse vir à tona conflitos que realmente estivessem presentes na relação dos pais com a escola dos filhos. 
Vale ressaltar que foi somente quando a coordenadora abandonou seu desejo, que o grupo passou a ocupar uma outra posição, não mais de antagonismo a ela, mas assumindo o lugar do "desejante", que ficou vazio. Pode-se dizer que a protagonista nessa etapa foi a Rose, que narrou uma situação, expondo que o filho se sente "marcado" pela vice-diretora da escola. Esse relato desencadeou vários outros, em que os participantes do grupo narraram situações pessoais ocorridas na escola. O apoio irrestrito à escola e ao professor, tão freqüentemente observado nas entrevistas individuais, provavelmente como defesa em relação às próprias idéias contestadoras, foi sendo quebrado. Os pais se aproximaram mais das vivências dos filhos na escola e narraram situações que destacaram a ocorrência de violência, discriminação e preconceito vividos pelos filhos. Eles afirmaram a importância do respeito mútuo entre os agentes escolares e os alunos.

O maior antagonismo aos projetos do grupo, a partir daí, foi a Gisele que, por estar muito próxima à escola, trabalhando como "amiga da escola", tomava sua defesa. Esse antagonismo, no entanto, não se mostrou muito consistente. A Gisele rapidamente mudava de posição e o seu relato reforçava de maneira intensa, por trazer vivências ocorridas na instituição, as questões trazidas pelos membros do grupo.

Antes de encerrar a sessão, o grupo retomou o contrato, questionando a pesquisadora sobre como esse material produzido no grupo seria utilizado. Eles mostraram o desejo de que ele fosse utilizado para produzir mudanças na escola.

O protagonismo do Sr. Mauro só ocorreu no final do encontro, mas mobilizou muito o grupo, que teve dificuldades em encerrar a sessão. Ele narrou de forma confusa, mas emocionada, o fato do filho ter perdido quatro dias de aula por causa do uniforme, enquanto outros alunos que estavam vestidos como o filho não sofreram nenhuma sanção. Ele se queixou, também, por ter ido à escola várias vezes para resolver a questão, inclusive no horário marcado pela escola, não tendo sido atendido. Enquanto isso, seu filho perdia as aulas, pois só poderia voltar a freqüentar a escola após a conversa do pai com a direção.

O Sr. Mauro pareceu estar pedindo ajuda ao grupo para compreender o fato ocorrido, tendo sido apoiado, principalmente pela Gisele e pela Rafaela, que identificou a ocorrência do mesmo problema com o filho. As pessoas mostraram cumplicidade e integração, o que se manteve no momento pós-grupo, quando foi oferecido a eles um lanche. Foi combinado, então, que seria realizada mais uma sessão grupal dali a quinze dias, data em que todos poderiam participar. De forma sucinta, será descrito a seguir, o 
movimento de cada entrevistado no decorrer da sessão grupal, sendo retomada sua postura na entrevista individual.

A Rose trouxe críticas que pareciam não estar conscientes no momento da entrevista individual, pois nesse contexto ela se mostrou absolutamente submissa e acrítica com relação a tudo que se passava na escola, repetindo sempre o discurso hegemônico da escola. Já no grupo, ela relatou situações sofridas pelo filho, questionando a postura da escola com relação a ele.

A Cibele também se colocou bastante no grupo e pareceu sentir alívio ao perceber o apoio de outras pessoas às críticas que já havia esboçado na entrevista individual.

A Rafaela pareceu se espantar com o que ia sendo colocado no grupo, percebendo questões antes desconhecidas. No final ela colocou que aprendeu coisas novas.

A Valéria quase não falou, mas se mostrou atenta a tudo, trazendo um olhar de satisfação, concordando com o que era falado com movimentos afirmativos com a cabeça.

A Carolina não entrou verdadeiramente no grupo, pois ficou o tempo todo preocupada com seu horário de sair (ela comunicou que sairia mais cedo).

A Maria retomou alguns questionamentos que apareceram no final de sua entrevista individual. Ela pareceu ter ficado desestabilizada após a conversa com a pesquisadora, precisando confirmar no grupo conflitos que ela não parecia se permitir sentir.

O Sr. Marcos foi o protagonista da sessão e seu relato tocou o grupo. $\mathrm{Na}$ entrevista individual apareceram algumas ambigüidades no seu discurso com relação ao sentimento de discriminação do filho na escola, mas foi somente no grupo que sua percepção emergiu de maneira mais clara. Vale notar que a situação só foi se tornando legítima no grupo, através de uma construção intersubjetiva. Ele saiu do encontro sorridente, talvez por ter se sentido acolhido, e pensativo (mais calado), talvez por necessitar elaborar um pouco mais o que se passou no grupo. Ele apontou que descobriu, participando do grupo, mais problemas do que soluções.

A partir das observações realizadas acima, pode-se dizer que o grupo facilitou que conteúdos não expressos na entrevista individual aparecessem. Mas isso só ocorreu no final da sessão quando a sociometria grupal se tornou favorável e a Gisele saiu do papel de protetora da escola. Nesse momento, o protagonista se revelou, o Sr. Mauro, 
aquele que provavelmente estava "agonizando" primeiro, sendo porta voz do sofrimento desse grupo específico.

\section{2 - O Segundo encontro}

\section{1 - Contextualização}

A Carolina (que havia ficado pouco tempo no primeiro encontro) confirmou que iria no segundo e avisou que a Cibele não poderia ir porque o marido estava viajando. Ela ainda pediu para que a data fosse mudada, mas isso não seria possível porque já estava confirmada com todas as outras pessoas. A Carolina, por fim, também não compareceu.

A pesquisadora buscou primeiro a Rose, que trouxe o filho mais novo e depois pegou a Gisele e a Rafaela. A Maria não estava pronta (pareceu ter se esquecido) e disse que iria depois a pé, mas acabou não indo. Vale notar que o grupo foi marcado nessa data por causa de um compromisso da Maria na semana anterior, já que ela havia dito para o grupo que fazia questão de participar no encontro seguinte. A pesquisadora deixou essas três participantes e o filho da Rose no Centro Comunitário e foi buscar a Valéria e o Sr. Mauro no outro bairro. O Sr. Mauro trouxe, dessa vez, um recorte de jornal falando de educação, sobre a comunidade na escola e deu para a pesquisadora. Veio ao encontro, também, a Sandra, uma pessoa que não havia sido entrevistada individualmente. Ela foi convidada pela Rose, que se empenhou muito para que o grupo acontecesse. A Sandra tem um menino na quarta série, estando, assim, dentro da amostra escolhida. A sua entrevista individual foi feita posteriormente.

O encontro começou às 19:20h e terminou às $21: 20 \mathrm{~h}$. A noite estava gelada e foi difícil suportar o frio que entrava pelas janelas sem vidros do centro comunitário. As pessoas não estavam esperando tanto frio e sentiram bastante, se encolhendo na cadeira, puxando as mangas das blusas. Essa situação chegou a ser bem desconfortável. Quando terminou o encontro, os participantes ainda ficaram lá comendo e conversando até dez horas. Eles não conseguiam ficar sentados, então se levantavam, andavam e diziam: "vamos embora, vamos embora que tá muito frio." (sic) No entanto, ainda ficaram um bom tempo conversando sobre assuntos pessoais como a depressão do marido (Gisele) e problemas do filho (Rafaela). Já a Rose ficou cuidando do filho que estava presente e 
conversando com a Sandra. Dessa vez a Valéria e o Sr. Marcos, que ficaram mais distantes no primeiro grupo, se aproximaram mais, mostrando-se bem enturmados.

A sessão foi calma, as pessoas falaram de maneira descontraída e mesmo a Sandra, que era nova, participou bem do grupo, se entrosando facilmente. Foram colocadas situações pessoais e específicas e não somente genéricas.

A pesquisadora não percebeu a necessidade de convocar o grupo para um terceiro encontro e nem os participantes falaram sobre isso durante a sessão grupal. Somente o Sr. Mauro, quando estava sendo deixado em casa, comentou: "Ah, que pena que acabou, acabou na hora que tava ficando bom." (sic) Ele mostrou satisfação em participar, se colocando nesse segundo encontro de maneira bem mais solta. Na medida em que a pesquisadora ia deixando cada um em casa, eles iam dizendo: “Oh, aparece aqui" (sic). Eles contaram, ainda, do dia dos pais na escola, falando que se a pesquisadora não pudesse ir, que eles iriam observar e avisá-la. Todos pegaram o telefone da pesquisadora, a Valéria a convidou para seu chá de bebê e a Rose, para ir tomar um café em sua casa. A Rafaela pediu uma ajuda, uma orientação em como lidar com o filho. Cada um tinha algo a dizer quando era deixado em casa.

\section{2 - Análise sociométrica e temática}

O segundo encontro foi subdividido em três etapas: Aquecimento, Desenvolvimento e Comentários, como pode ser observado a seguir.

\section{Etapa 1: Aquecimento}

\section{Projeto1 - Retomada do encontro anterior.}

$1^{\circ}$ Momento: A coordenadora pediu para que os participantes falassem sobre o que havia ficado para eles do encontro anterior, se colocando como protagonista. $\mathrm{O}$ grupo embarcou na proposta e a Rose confirmou as críticas à vice-diretora, feitas no encontro anterior. O Sr. Mauro concordou com ela e afirmou que não vai mais permitir que o filho perca aula por causa do uniforme. Ele passou a acreditar que tem o direito de tentar, não é porque o filho é arteiro que ele vai desistir. A Gisele e a Rose o apoiaram, como pode ser visto a seguir: 
Mauro: Como meu garoto foi jogar... Eu posso transferir? Não. Ai fica dificil.(...) Falei: "Não é porque eu sei que ele é meio arteiro?(...) Faltar da escola também não vai. Já faltô demais, tá dando problema. "(...) Porque, por causa do uniforme ele não vai voltar mais. (...) É prioridade a escola, eu entendo. Eu tô careca de saber disso. Mas eu não tenho uma alternativa? Agora eu sou abrigado segurar ele aqui, fazer ele chorar?

Gisele: Mas, por que não quiseram trocá ele de periodo?

Mauro: Não, não pode, não sei o que. Só se for em outra escola.(...) "Eu tô entendendo a posição do senhor, o esporte e a escola até é bom que caminhe junto."(...) A escola disse que não tem jeito, a dona Sônia diz que não deixa ele faltar. Mas não tem problema nenhum. Só que eu acho que tá errado. Inclusive ele conseguiu a bolsa e não deixa que ele faça? A diretora mesmo não se envolveu em nada.

Gisele: Mas assim eu não consigo entender.(...) Deixa ele matriculado à tarde, mas deixa ele freqüentá a escola de manhã. Não sei, eu acho que tem tantas alternativas que, não é? (...) É uma criança que precisa dessa troca.

Mauro: É, cada situação é particular.

Gisele: Eu acho que eles não facilitam as coisas.

Rose: O problema é seu, resolva você.

$2^{\circ}$ Momento: A conversa anterior gerou o assunto sobre o salário baixo dos professores, tendo como protagonistas o Sr. Mauro, a Rose e a Sandra. O restante do grupo mostrou uma postura de parceria para com os protagonistas. Nesse momento, o grupo ainda tratava de questões mais superficiais.

Mauro: Tem cabimento uma coisa dessa, aumento de 5\% ? Isso não existe né. Tem cabimento uma coisa dessa?

Rose: Porque eu acho que pra gente ter um bom salário tem que ser reconhecido. É a onde que causa o problema na escola. Eles irritam tanto que começam a pegar as crianças.

$3^{\mathbf{0}}$ Momento: A Gisele contou sobre questões que aconteceram na escola no decorrer das duas últimas semanas, que a fizeram lembrar do que havia sido conversado no grupo. Ela ressaltou a falta de educação da vice-diretora e o fato de alguns alunos serem rotulados. Seu relato pode ser observado a seguir:

Gisele: Aí, hoje, a mãe foi lá na escola, diz que a Mirtes (vice-diretora) foi muito agressiva com ele, foi estúpida, muito sem educaçona. Desceu, foi lá pra delegacia também, e se tornou o horror lá na escola.(...) O menino ficou nervoso, porque diz 
que a Mirtes passô maior sabão.(...) Ai, esse também é taxado como danado: "porque ele é isso, porque ele é aquilo. Mas também, ah, tinha que ser ele." Eu não acho que é por aí.(...) É igual aquele negócio do uniforme. Um dia ou outro o menino dele (se referindo ao Sr. Mauro) não ia com o uniforme da cor. Mas lá tá cheio de gente que não vai com a calça da cor. Mas porque é com ele e com esse que apanhou na cara também: "Olha lá gente, ele não tá de uniforme." Mas tem uma porção de gente que tá sem e ninguém vê. Ai é aquele porque ele é mais danado. Todo mundo enxerga ele porque ele tá sem uniforme, porque ele tá brigando na fila, porque ele tá assim e não pode.(...) Então ele vai sempre continuá dando trabalho, sempre sendo pisado na escola por causa daquilo e não pode, entendeu?

\section{Etapa 2: Desenvolvimento}

\section{Projeto1- Discussão de temas genéricos - críticas à escola e aos professores.}

$1^{\circ}$ Momento: A Gisele e a Rafaela criticaram o fato das crianças não poderem sair da classe para ir ao banheiro e beber água. O restante do grupo as ouviu atentamente, não havendo unidades sociométricas antagônicas.

Gisele: Tem um lá que tem problema e toma remédio controlado, então, de uma em uma hora ele tem que sai lá fora pra tomá água. A Mirtes impôs uma lei. Agora não qué, e que é pra todo mundo levá uma garrafinha de água e não é pra saí.(...) Então eu acho gente, tem umas coisinhas até que eu vô tê que falá.

Rafaela: O meu menino leva uma garrafinha de água, ele toma muita água. Agora, a professora falô que não pode levá a garrafinha de água mais. É só na hora do recreio e nem i no banheiro.

Gisele: Hoje o meu menino saiu da escola e: "Mãe, corre que eu tô fazendo xixi, mãe corre." (...) Depois que você volta do recreio não pode i no banheiro.(...) Mas tem dia que, por exemplo, sua bexiga não sabe que depois do recreio você não pode ir pro banheiro.

$2^{\circ}$ Momento: Em seguida iniciou-se o assunto relativo às críticas às professoras, tendo sido colocado que as crianças estão tendo medo de uma delas. As protagonistas nesse momento foram a Gisele e a Rafaela, que narraram situações ocorridas com os filhos, como pode ser visto a seguir:

Gisele: Ela (a professora) falô assim pra ele (filho) apagá isso aí que tá errado. Ele já morre de medo dela.(...) Eu peguei, fui lá e falei pra dona diretora.(...) Eu falei: não eu não tô implicando com ela (com a professora), uma que eu nem dô asa pra ele(filho): "Ela é assim mesmo. É o jeito dela. Você tem que acostumá. É sua professora. Não tem jeito de tirá ela de lá." Aí ela não fala nada, sabe? 
Rafaela: Eu não sei se você viu seu menino levar umas contas com processo diferente prá fazê. O Hélio(filho), não entra na cabeça dele. Eu peguei e mandei um recadinho pra ela. Se ela achasse uma maneira mais fácil pra explicá pra ele, né? Ela falô pra mim, assim: "Tá muito difícil. Eu já expliquei individualmente e ele não aprende." Aí ficô por isso mesmo.(...) O meu não fala nada. Ele tem medo dela.

Gisele: Todo mundo tem.

\section{Projeto 2 - Temas pessoais - início de aprofundamento dos relatos.}

$1^{\circ}$ Momento: A Gisele se queixou de que uma professora a acusou de estar na escola para vigiar as professoras. Sua defesa foi especificar sua função na escola (vigiar somente os alunos), apontando que não tem estudo para avaliar os professores. Ela buscou uma solução, conversando com a diretora, que disse para ela falar desse assunto na reunião. Esse posicionamento da diretora não parece ter sido visto pela mãe de forma crítica, assim como a fala da professora. A Gisele apenas se defende da acusação, como pode ser observado no seu relato:

Gisele: Ela (a professora) deu de achar assim, que eu tou ali pra vigiá.(...) Falou que tem umas mães que eu vô te falá, parece que tá de olho nas coisas que a gente tá fazendo.(...) Eu não tô lá pra vigiá professora. Uma que eu não tenho estudo.(...) Eu vô sabê se o método que ela tá usando está certo ou se tá errado? Porque eu não sei.(...) Eu tô lá pra vigiá os meninos na hora do recreio e fazê a minha parte. Aí eu falei tudo prá Sônia, ai ela falou que vai tê reunião dia quatro, é prá mim falá na reunião.

$2^{\circ}$ Momento: A Rose trouxe uma situação em que a professora se queixou do seu filho para o pai injustamente, como pode ser verificado a seguir:

Rose: Já com o meu aconteceu o seguinte: o meu menino faltou da aula porque tinha que $i$ no médico. Ela foi falá pro meu marido.(...) Ela disse: "seu filho não tá copiando as coisas." Aí eu chamei o José(filho).(...) "Você vai pegá esse caderno e vai falá pra professora: O que tá faltando que eu não fiz?". Porque o pai dele vai pensá o seguinte: eu trouxe a mãe pra cuidá, ela não tá cuidando. Vai achá que eu sô o quê?(...) Agora, você foi falá uma coisa que não tava acontecendo, porque o meu filho? Eu traga aqui, ó.

$3^{\circ}$ Momento: O Sr. Mauro retomou o tema da sessão anterior, relatando as dificuldades do filho e mostrando ao grupo sua impotência para resolver esse problema. No mesmo sentido dos relatos anteriores, sua fala é predominantemente emocional, tendo mobilizado os outros participantes do grupo, como pode ser visto a seguir: 
Mauro: Igual, no caso que a senhora tá explicando, o meu tem essa mesma dificuldade de acompanhamento desde quando deu um problema no crânio. Furô o crânio. Então, até então ele tratava com o doutor Celso. Isso aí vai acontecê até uma faixa da idade dele. No C. M. (escola) tem é, como que fala? Relatório dele. Tem radiografia, tem uma série de coisas lá. Aqui também, eu cheguei a trazê também. Eu falei: "Ah, batê eu já bati. Agora, a não ser que a senhora queira que vou batê nele todos os dias.(...) Não tá resolvendo nada porque arteiro ele é.(...) Ele é esperto, aquele lá. É esperto mesmo.(...) Porque esse negócio de dificuldade de aprendizagem, eu queria, eu quero dizer assim, não é o único. Isso já vem faz tempo. (...) Ele não acompanha..

\section{Projeto 3 - Disputa de protagonismo - movimento alternado de fuga e aproximação do tema trazido por um dos integrantes do grupo}

$1^{\mathbf{0}}$ Momento - Fuga: Apesar do Sr. Mauro tentar manter-se no assunto do filho, o grupo voltava para assuntos genéricos. A Gisele foi a principal protagonista desse movimento, elogiando as professoras dedicadas e criticando aquelas que deixam as crianças com dificuldades de lado. Ela elogiou, também, aquelas que conseguem soluções alternativas para ensinar as crianças que têm dificuldade. O grupo a apoiou totalmente, especialmente a Sandra e a Rose. Esse momento do grupo pode ser observado a seguir:

Mauro: Problema existe em todos os niveis sociais, no trabalho, escola, bairro. Se fosse separar os bons e ruins... (...) Agora, aquelas crianças que têm dificuldade em alguma coisa, bom, o que a gente vai fazer? Vamos procurar, são 90 garotos ou garotas que estão com um aprendizado assim, não que saibam, porque, na minha concepção, burro não existe ninguém.(...) Ele é melhor em alguma coisa.

Gisele: Porque às vezes tem gente com dificuldade, por exemplo, sei lá, pegar para fazer uma conta. (...) A professora falou assim, na reunião, pra mãe, antes da mãe perguntar do filho, ela já foi falando assim: "Olha, eu tenho um carinho especial pelo seu filho.(...) Só que ele não copia a lição da lousa.(...) Eu preciso encontrar um jeito de despertar ele pra ele poder escrever".(...) Eu penso que ela é muito dedicada porque ela já tá tentando arrumar uma forma de despertar a atenção dele.(...) Tem muitos casos que a professora fala: "Ah, ele não tem jeito, ele não quer." E deixa, entendeu?(...) Ela tem que: "Gente, me ajuda?" Conversa com outras professoras, e vê: "Gente, ó, o menino, já ensinei de todo jeito." Porque eu acho assim, não é porque ela é professora, também, que ela sabe tudo, não é? Às vezes tem alguma coisa que ela não sabe.(...) Ele vai aprender de alguma forma. Às vezes ele pode ser um pouco mais lento que o outro, mas ele vai chegá lá.

Mauro: Teve uma época que eu falei que ia mandar ele para a APAE. Ele falou: "Eu não vou, não. Eu não sou doido. Eu não vou, não adianta." 
Sandra: $O$ ano passado, a Mirela (professora), ela no finalzinho do ano ela falou assim: "Eu fiquei com dó do aluno que tinha mais dificuldade, eu fiquei com pena de colocá ele aqui né. Então deixa ele.(...)Ai, começou esse ano com dificuldade.

Gisele: Lógico, igual o ano passado a Mariana (professora)(...) Acho que ela tinha 15 bons. Ela pegou aqueles 15 prá ensinar porque, às vezes, a própria criança fala com a outra de jeito que você não consegue falar. Ele aprende com o coleguinha. Ensinando melhor do que a gente lá. (Várias pessoas falando)

Sandra: Ela colocou um prá ajuda o outro, um ajudando outro. Eles ficavam em grupinhos.

Rose: Se ela pegar os melhores da classe, por um grupo ali, fazê igual ela falô, um coleguinha ensiná, às vezes o que um colega vai passá pro outro coleguinha é melhor que ela explicando.

$2^{\mathbf{0}}$ Momento- Aproximação: A Rose, o Sr. Mauro, a Gisele e a Rafaela trouxeram uma crítica ao fato da escola jogar a culpa das dificuldades somente na criança e nos pais. $\mathrm{O}$ Sr. Mauro relatou, também, que desejou muito tirar o filho da escola, quando viu que nada resolvia. Nesse momento houve uma aproximação do tema protagonista e o grupo se colocou na escuta do problema do filho do Sr. Mauro e da sua impotência em resolvê-lo. Ele pareceu se defender desse sentimento, apontando que aprendeu tudo sem ajuda dos pais e, no entanto, com seu filho, todo o apoio dado não surte efeito. Esse momento do grupo pode ser verificado a seguir:

Rose: Eu acho assim, se fosse problema meu e do meu marido o que o meu filho tá passando, prá quê que eu vô leva ele prá escola, prá quê então que tem escola?

Mauro: E eu se eu tirar o meu, eu vou preso, tenho certeza.(...) E o ano passado quase que eu tirei ele, falei: não vai mais, pronto e acabô, vai ficá aqui em casa. E deixa que eu responsabilizo. Porque vai lá, vem aqui, eu já tó por aqui.(...)Tinha uma amiga minha que queria dar aula prá ele final de semana. E eu ia tirar mesmo, ele da escola.(...) "Não adianta forçar, seu Mauro, o que o senhor acha que tem que impor. Não bate nesse garoto. Não vai resolvê APAE, não adianta levar ele prá lá. Forçá também não vai resolvê. Eu falei: "mais doutor Celso, o quê que eu faço agora?" Então ele vai na escola, mais aí num vai resolvê nada. E não resolveu, a cobrança continuou.

Rose: E se ele chega lá, eles vai falá que é problema do seu pai e da sua mãe.

Gisele: Mais então, eu acho um absurdo.

Rafaela: É falta de vontade.

Mauro: Eu mesmo já tive essa conversa com a dona Sônia e foi, acho que umas duas horas ou mais.(...) A conversa foi até chegá no meu garoto.(...) Era só aqui, ó, eu falei pra ela como eu sendo mais velho.(...) Como que minha mãe ia me ensinar, se ela não tinha estudo? E o meu pai entrava na padaria 4 e meia da manhã. Quem que 
me ensinava, a senhora tem uma resposta prá me dar?(...) Igual, eu tenho livros, enciclopédia, tem uma série de coisas que eu comprei faz muitos anos, muito tempo, gente. Tá dando problema? Espera aí, a gente pega a enciclopédia, tal, tal.(...) Tá tudo aqui, olha. No outro dia você vai olha tá do mesmo jeito.

$3^{\circ}$ Momento- fuga: A Gisele e a Rose trouxeram um outro tema que é a diferença do ensino antigamente e atualmente, mostrando um esforço em compreender as contradições presentes nesse assunto. Elas criticaram a rigidez do ensino antigamente, se queixando do alto grau de agressividade dos professores, mas exaltaram o fato de que os alunos realmente aprendiam. O Sr. Mauro concordou com elas. Ficou clara a insatisfação pelos filhos não estarem aprendendo hoje em dia.

Gisele: Ele(professor) não andava e se os meninos fizesse alguma coisa de errado ele falava: "Fulano, vem aqui que eu vô te batê."(...) E se não fosse apanhava dobrado. Apanhava do pai, da mãe e apanhava do professor na escola, entendeu? Então, pra você vê como que era as coisas.

Rose: E ele levava vara de marmelo prá batê.(...) Castigo era de joelho em cima do milho ou tampinha de garrafa. Agora, você imagina, hoje põe menino de castigo, eles racha o bico de ri.

Mauro: Tinha o prazer em ensinar.

Gisele: E a criança aprendia mesmo. Não é igual agora.

\section{Projeto 4 - Protagonismo difuso: três mães relataram situações específicas que causaram sofrimento.}

$1^{\circ}$ Momento: A Rafaela trouxe uma situação pessoal onde houve falta de entendimento da professora quanto às dificuldades do filho. Ela colocou que não tem nada na escola que chame a atenção dele, mostrando um sentimento de impotência ao tratar disso com a professora, pois essa relata que não pode fazer nada porque tem mais de vinte alunos na classe. Esse momento do grupo pode ser verificado a seguir:

Rafaela: O Hélio não gosta de faltá da escola. Mas eu não sei, ele vai na escola pra, eu não entendo, não tem o que chama a atenção dele, sabe? E eu já conversei com a professora dele, a Nair. "Ah, Nair..." Falei: "Ele tem problema porque ele não acompanha." Né? Eu falei: "Eu vô levá ele no psicólogo." Ela falô: "Psicólogo não adianta nada, não resolve nada. Você já fez exame de cabeça dele?" Eu falei: "Eu nunca fiz, mas ele não tem problema de cabeça." Porque o menino tem problema de sê diferente, né. Ele não pensa, na escola ele é mais difícil, nas coisas. 
Gisele: É porque ele não tem nada que chame a atenção dele.

Rafaela: Ela falô isso pra mim, ai eu fui explicá pra ela que ele é filho adotivo, que os pais dele tinham problema, que mexiam com droga, que foi dificil, né? Então, ela tinha que dá mais atenção pra ele porque a Mariana (outra professora) fazia isso, dava atenção. Mas ela falô assim: "Mas eu tenho mais de 20 alunos na classe, eu não posso ficá em cima dele o tempo todo." Eu, então, se ela não pode, fica dificil.

$2^{\circ}$ Momento: A Sandra também relatou uma situação em que o problema do filho na escola foi jogado em suas mãos para ser resolvido, sem que ela soubesse como fazê-lo. Ela mostrou sofrimento ao relatar o fato, queixando-se de ter se sentido sozinha e pressionada pela escola. Ela questiona a integração família-escola. Sua fala pode ser verificada a seguir:

Sandra: Eu vivi uma situação assim: o meu menino nunca foi agressivo, sabe? Desde pequenininho, brincava, não batia, ele nunca foi agressivo. Mas ai ele perdeu o pai dele, ele tinha menos de 6 anos. Então ele é muito calado, fechado, nunca falou prá mim que tinha saudade do papai, nunca. Então eu acho assim, ele começô a expor aquela dor assim em forma de agressão, começô agredir os coleguinhas na hora do recreio. Eu fiquei assustada com aquilo. Ela (a vice-diretora) ligô pra mim, falô que ele tinha empurrado um menino, sabe? Eu não sei, não tô conhecendo ele, porque ele não é assim. Outro dia era oito horas eu tava conversando com a Mirtes (vicediretora). Então, ela foi assim, muito agressiva, brava com ele como se tivesse falando com uma pessoa adulta, sabe? Não procura sabê, porque se ele não é assim, por que ele tava fazendo aquilo né? Não procura sabê qual é o problema. É isso ai mãe. Colocou o problema. "Você conversa com ele e resolve esse problema, aí. Porque, senão eu vô tê que tomá atitudes mais drásticas." Então a gente fica assim com o coração. É o que eu vou fazê? Batê não adianta. Ainda mais nessa situação perdeu o pai, quer dizê, muito fechado, fica no mundinho dele, então o que eu vô fazê? Conversei e pedi pra Deus pra solucioná meu problema, porque ele não pode sê agressivo. Ele não é assim. Então, o que eu vô fazêe? Eu me sinto sozinha e a dona Sônia sempre fala que a família na escola, os pais, né? Eu não vi desde que saiu isso, eu não vi aquele apoio sabe? Só falo prá mim: resolve mãe, porque se ele continuá assim, nós vamos ter que tomá uma atitude drástica mesmo. Eu falei, Nossa! Mas e se eu conversar e não adiantar.(...) Eu falei pra ele: "Não é assim filho, Deus levô o papai só que a gente não pode fazê isso. Ninguém tem culpa." E ele entendeu, porque se ele não tivesse entendido eu tinha tido mais problema com ele, porque jogaram na minha mão. Segura, e resolve. Eu e ele se sentiu só.

A Gisele, em seguida, apoiando a Sandra, relatou uma situação que vivenciou, em que uma outra mãe não sabia o que fazer para enquadrar o filho às exigências da escola:

Gisele: Todo mundo morre de medo da Mirtes. Os meninos tá no pátio, aquela correria, a Mirtes chega, todo mundo pára. As professoras também têm entendeu? (...) (a Mirtes) falô pro menino assim: "Tá parecendo malandro com essa bermudona." Mas bermuda curta não pode. Ai ele coloca a comprida. Também não 
pode. Tem que chegá num consenso.(...) A mãe dele já falô chorando pra mim, falô:

"Gisele, o que eu faço?"

$3^{\circ}$ Momento: A Rose narrou um conflito entre o filho e a vice-diretora, colocando o quanto é chato ser chamada na escola, porque nessas situações ela se sente como se não estivesse cumprindo bem o seu papel de dar educação aos filhos. Essa fala mostra o quanto o papel de mãe atualmente está ligado à identidade pessoal. Se os filhos "falham", elas também se sentem "falhando". As mães se sentem facilmente culpadas e apoiam a escola, na maioria das vezes, de forma irrestrita. O relato da Rose pode ser observado a seguir, além das falas da Gisele, apoiando-a:

Rose: "Chama tua mãe aqui, e sua mãe tem que vir." Porque meu menino apontou o lápis e passou o lápis debaixo da carteira.(...) Aí, mandô me chamá lá, de noite.(...) "O seu menino me respondeu." E o Gustavo não é de responder. O Gustavo é um menino calado.(...) "Mais mãe, no meio daquele tanto de gente ela apontô o dedo que era eu que tava fazendo coisa que eu não tava fazendo."

Gisele: É igual eu te falei, ela taxa um.

Rose: Fui lá, conversei, mas é chato. Agora graças a Deus ele saiu dessa escola, porque é chato você ser chamado lá. Dá impressão, assim, você não dá educação pros seus filhos.

Gisele: É, porque a hora que fala assim: "O problema é seu e do seu filho." Dá impressão que a gente não tá dando conta, né?

Rose: É, dá impressão que a gente não tá dando conta, né?

$4^{\circ}$ Momento: O tema da Rose deu origem a um outro assunto que é a importância atribuída à participação dos pais na escola, criticando aqueles que ficam ausentes. Esse tema foi endossado pela Rafaela, Rose, Gisele e Sandra, quebrando o fluxo dos relatos mais pessoais, voltando aos mais defensivos.

Sandra: Só que eu acho assim, que deixá de ajudá e ir nas reuniões também não é a solução, porque tem mãe que não vai.

Rafaela: Tem um menino que estuda com o meu, faz três anos que estuda junto. A professora até hoje não conhece a mãe dele e ele é o que mais dá problema na sala de aula.

Rose: Igual a Mirtes. Quem conhece a Mirtes nem vai porque sabe que vai passá vexame mesmo.

Gisele: Mais é no caso prá conversá com a professora eu acho que a mãe devia ir. 


\section{Projeto 5 - Elaboração dos temas pessoais trazidos e busca de soluções}

$1^{\circ}$ Momento: A Rafaela retomou o assunto relacionado ao seu filho, relatando que nos encontros do grupo percebeu que o problema não está só no filho, que não é só ele que está sempre errado. Ela confessou que cobrava demais dele e que agora tem buscado outras alternativas. A Gisele a apoiou, buscando uma solução. Esse momento do grupo pode ser observado a seguir:

Rafaela: Eu pensava o seguinte; que fosse só com o Hélio. Antes dessas reuniões aqui, do grupo eu sempre tava cobrando muito dele em casa porque ele não aprendia. Eu falava: "Hélio, vê os outros colegas, vê o caderno do Caio que bonito, né?" Então, eu achava que eu tava errada, antes de saber dessas coisas que tá acontecendo.

Daniela: Você fala dessas conversas aqui, Rafaela?

Rafaela: É, não é só ele o aluno que não tá desenvolvendo.

Gisele: É, ele não é o único. Tem vários.

Rafaela: E ele é um menino assim, ele não é respondão. Ele é muito educado, problema de comportamento ele não tem. O problema é as lição. Ele não liga. Se passá um mosquitinho aqui ele vai acompanhando até no fim. Ele não consegue.

$2^{\circ}$ Momento: A Gisele iniciou elogiando a abertura e maleabilidade da diretora da escola, sugerindo que se falasse com ela para resolver os problemas. O Sr. Mauro concordou com essa observação, mas ressaltou que nem sempre a diretora está na escola para resolver esse tipo de situação.

Gisele: É igual a dona Sônia(diretora), por exemplo; se falá isso pra ela eu tenho certeza que ela vai pensá nas possibilidades, porque ela é mais humana do que a Mirtes, entendeu? Ela senta pra te ouvir.(...) É porque eu acho que a Sônia é mais maleável.

Mauro: Ela só não tá lá sempre, porque ontem eu não sabia quem tava lá.(...) Não adiantou nada.

\section{Etapa 3: Comentários}

Desde que a coordenadora anunciou o fechamento da sessão, até que isso realmente ocorresse, o grupo percorreu ainda um longo trajeto. Podem ser identificados 
sete projetos nessa etapa de fechamento do encontro. Talvez isso tenha ocorrido devido à necessidade de elaboração e fechamento das várias questões abertas no decorrer do encontro.

\section{Projeto1 - Levantamento de alternativas}

$1^{\circ}$ Momento: A coordenadora pediu para que o grupo pensasse, frente ao que havia sido discutido, em pequenas soluções que cada um poderia buscar para os problemas levantados. O objetivo aqui era dar uma devolutiva ao grupo, por menor que fosse, minimizando os efeitos da angústia causada pela tomada de consciência de questões que estavam latentes. Eles foram convidados, nesse momento, a instrumentalizar-se um pouco mais para lidar com a realidade. A resposta, no entanto, foi de queixa dos participantes que faltaram, por parte da Rose. A Valéria, que havia se manifestado muito pouco, também refletiu sobre a sua participação no grupo, colocando que aprendeu coisas novas. A Rafaela fez sua elaboração, apontando a relatividade do poder da professora, assunto que foi complementado pela Rose. Esses relatos podem ser verificados a seguir:

Rose: É igual eu te falei, você chamou aquele tanto de pai, você vê quanto de pai tem interesse de vir? Geralmente aqueles tanto não tem interesse tanto da escola nem da reunião que você tá fazendo aqui.

Valéria: Valeu mesmo assim. Conversando aqui a gente entendeu coisas que acontece que a gente não sabia que acontecia.

Rose: Matricular o filho na escola tá ótimo. Chega, deita e dorme. O problema, tem que ver aonde tá o problema. Vai ser difícil, mas não vai ser impossível.

Rafaela: Porque ela é a professora, ela sabe mais do que a gente, né? Às vezes não é assim, também, né? Pelo menos a maneira, o jeito de explicar.

$2^{\circ}$ Momento: A coordenadora retomou o levantamento de alternativas, pedindo que cada um desse a sua opinião. O Sr. Mauro colocou que a criança não dá problema por causa dos pais e que a escola deveria ter uma maior diversidade de disciplinas para incentivar o aluno. Ele apontou, ainda, a importância de se dar valor àquilo que a criança faz de bom. Vale ressaltar que esse é o primeiro momento em que ele se coloca de forma explicitamente crítica, não atribuindo a responsabilidade exclusivamente ao filho. A Sandra sugeriu a criação de um grupo de auto-ajuda para alunos com 
dificuldades. A Gisele colocou que os pais também iriam e o Sr. Mauro complementou que não deveria ser oferecido somente aos alunos "problemáticos" e, sim, à toda a escola e que não se deveria especificar e dar nome àqueles que tinham problemas para não constranger os pais. A Gisele colocou, ainda, a importância do sigilo grupal. Esse momento do grupo pode ser observado a seguir:

Mauro: Primeiro item.(...) Um garoto de cada classe esteje dando problema. Um. Com certeza um pequeno espaço tem de existir ali, um meio pra essa criança parar de dar problema. Essa criança, eu tenho certeza que não dá problema porque nós tamo em casa.(...) Uns é através do estudo, através da música, outros é através do basquete, outro do futebol ou de violão. Há incentivo.(...) O meu eu tô tentando faz tempo.(...) Ontem mesmo ele já chegou, pegou o caderno dele, entrou lá, estudou, começou a desenhar.(...) Eu não mandei ele desenhar.(...) Então, quer dizer, a motivação tá partindo dele.(...) Quer dizer, tá melhorando.(...) Não tem como você só regredir.

Sandra: Se tivesse tipo um grupo, tipo assim, de apoio? Tipo o AA assim, né? E os alunos igual falou, em cada classe tem um, dois de cada classe, pegar aqueles, convidar, fazer uma reunião, igual a gente tá aqui, só com aquele. Prá conversar, prá ver quem faz isso, porque que ele faz aquilo, né? Eu acho que ajudaria e os pais teriam que dar apoio também. Sem os pais, uma reunião, só eles.

Gisele: Então, só que é igual eu tô te falando, no caso desses aí, você chama e fala assim: "Ó, você tá convidada a participar." Às vezes os pais até vai. Igual, você fala: "Eu não vou falar do seu filho." Ao invés de você falar assim: "É o seu, é o nome dele."

Mauro: No geral.(...)Eu não vou falar assim, nós vamo falar assim, ó: "O que vocêis acham que assim prá melhora pró seu aí, "né?" Vai falar no seu sem ninguém saber que você é pai dele. Não, é porque eu acho que seria o zero, que os pais tenha que sê constrangido, eu acho que é isso.

Gisele: É um sigilo absoluto. Ninguém tem que falá nada, não tem que dá nome, não tem que falar nada, entendeu? Eu acho que seria interessante eles estar todos os dias na escola, tá colocando isso em prática, assim.

$3^{\circ}$ Momento: A Gisele colocou a importância do grupo de pais, dizendo que se uma mãe sozinha busca tratar dos problemas do próprio filho, ela é vista como alguém que vigia a escola e a questão é tomada como pessoal. Se for um grupo de pais essa situação muda. Seu relato pode ser observado a seguir:

Gisele: É, porque o filho é dele, o problema é dele. Então ele tá vigiando, então é por isso que eu acho que tinha que ser assim, tinha que ser montado um grupo justamente prá aqueles casos. Você tá disposta a ser voluntária desse grupo, de vir aqui uma vez por semana tentar solucionar os problemas, né? Tentar solucionar, sei lá, só essa palavra. Mais assim sei lá, de às vezes tá dando até uma, igual o que ela falou, 
mesmo, você tá dando uma orientação prá podê a pessoa estar sabendo né, como lidar com a situação.

\section{Projeto 2 - Reflexões sobre a vida pessoal.}

A Gisele e a Sandra levantaram, nesse momento, questões relativas à vida pessoal, sendo que a Gisele falou da depressão do marido e a Sandra falou da importância de não mentir para os filhos.

Gisele: No caso do meu marido, tá com depressão faz um ano.(...) Faz 11 anos que eu tô junto com ele, não consegui mudar ele. Você tem que se mudar pra você aprendê a conviver com ele como ele é." Porque pra mim, depois que eu tive essa conversa com ele, foi muito melhor, entendeu?(...)Tô falando isso agora aqui prá citar como exemplo porque eu acho que o grupo de apoio é bom. Porque aí você vai vê pessoas que tem problema semelhantes ao seus e que não é só você.

Sandra: Eu falava assim não mente, não mente, não mente.(...)E eu falei prá ele(filho) dizer: diz que eu não tô. Ele chegou prá ela e disse: "A minha mãe mandou dizer que não tá.” Eu falei, gente. Porque a criança não sabe o que tá fazendo, não adianta eu ficar brava com ele. (várias pessoas falando)

\section{Projeto 3 - Críticas ao não comparecimento de uma mãe e aos pais que não participam}

A Rose se queixou da Maria que pediu que o encontro acontecesse nessa data e acabou não comparecendo. Criticou também a falta de participação de outros pais. $O$ restante do grupo acenava coma cabeça, concordando com a sua fala, que pode ser verificada a seguir:

Rose: E faltou aquela que falou que vinha. Não veio nada.(falando da Maria)

Gisele: Veio nada, nóis passô lá na casa dela (várias pessoas falando)

Rose: Hoje mãe e pai não quer nem saber de nada, põe o filho e graças a Deus já foi prá escola, graças a Deus. Porque tem que vê pois lá. mais a outra pessoa vai ter que ter a responsabilidade tem que ficar de cima. É pro meu filho, então vou procurar resolver. É com o professor, então vou tentar com o professor. 


\section{Projeto 4 - Retomada de temas específicos relativos à escola}

$1^{\circ}$ Momento: Nesse momento a Valéria, que não havia se colocado ainda, trouxe a sua insatisfação com o reforço escolar da filha, o que provavelmente é o que mais a incomoda no momento. A Rafaela e o Sr. Mauro concordaram com ela, expondo também sua insatisfação, como pode ser observado nos relatos a seguir. Observa-se que o Sr Mauro tirou o filho do reforço não por criticar sua eficiência, mas sim porque o filho é arteiro e dava trabalho.

Valéria: Eu não tô gostando do reforço.

Rafaela: O meu vai segunda, terça e quarta, fica até as sete. Eu vou olhar no caderno dele sabe o que eles fazem na aula de matemática? Um papelzinho desse tamanho assim com as continhas que você nem enxerga os números. Não é verdade?

Valéria: É verdade.

Rafaela: Eu falei Hélio, o que você vai fazer com isso aqui, os números tudo apagado? Meu marido falou: "É pra segurar as crianças lá e cansar também porque não tá virando nada."

Valéria: A minha mãe falou que é prá mim tirar a Denise que ela vai ensiná ela, a Denise. (várias pessoas falando)

Mauro: O meu também começou a fazer reforço e eu tirei ele porque era muito arteiro. O meu menino não tava aprendendo nada. Agora ponho na aula de reforço e ele faz arte. Não vou mexer com isso não.

$2^{\circ}$ Momento: Em seguida a Rafaela trouxe sua reflexão, apontando que percebeu que às vezes cobra o filho injustamente:

Rafaela: Eu mexi na mochila do Hélio e falei: Hélio isso aqui é lição prá você fazê, por que você amassou e não pregou no caderno? Não, mãe a professora não gosta que prega.

Gisele: Não gosta que prega, tem que copiar tudo.

Rafaela: E eu brigando com ele, porque eu tava pensando que ele não queria fazer lição, tava jogando fora prá esconder de mim.

Gisele: Não, é ela que manda jogar fora. 


\section{Projeto 5 - Avaliação do encontro}

A coordenadora pediu que os participantes avaliassem o encontro, colocando o que acharam ou sentiram. A protagonista do grupo nesse momento foi a própria coordenadora e os integrantes do grupo responderam sem resistência. A Rose colocou que um aprendeu com o outro, a Rafaela disse que percebeu que os problemas não são só dela e que em grupo os resolve melhor. A Gisele colocou que gostou de contribuir com o grupo e a Sandra disse que gostou da experiência, que sentiu o apoio do grupo. A Valéria colocou que descobriu que não é só ela que tem problemas e o Sr. Mauro disse que se sentiu unindo esforços. A coordenadora fechou, então, o encontro. A Gisele ainda colocou para a coordenadora que ela deveria ser a porta-voz dos pais, representando-os na escola. Alguns relatos ilustrativos desse momento podem ser observados a seguir:

Rafaela: Eu descobri coisas que eu não sabia. Eu achava que era um problema só meu. Só eu que tinha esse problema, né? Mais vi que cada um tem o seu e tá todo mundo tentando resolvê, porque às vezes gente tenta resolvê sozinha e não consegue. Então eu acho muito melhor assim.

Rose: Um vai aprendendo com o outro, né? Cada um vai dando uma idéia, vai aprendendo, vai falando aquilo que sente, se é errado, se não é.

Gisele: Assim prá mim que tem esse contato com todo mundo, eu acho que é válido essas reuniões. De tá vindo, essas coisas. Igual no caso você falou que foi ela (se refere à Rafaela) que foi ela que falou prá você me entrevistar. Eu fiquei muito agradecida por você ter dado a sugestão, porque prá mim também foi muito e tá muito bom.(...) E uma cabeça sozinha não pensa né. Mais um monte de ideinha. Ela, por exemplo, que ainda não tinha vindo em nenhuma (se refere à Sandra) Aí olha, já chegou com uma idéia brilhante hoje aqui. Então eu acho assim: Que foi muito bom sim.

Sandra: Então eu gostei porque eu fico em casa.(...) Lá com a minha família eu posso ter apoio, mais não nesse sentido lá dentro. Então tem que ser nesse grupo mesmo. Eu gostei sim.

Valéria: Eu também gostei e igual ela falou, eu também imaginava que era só eu que tinha esse problema, né. E cada um tem o seu.

Mauro: Como se diz, o melhor exercício pro coração é aquele que ajuda. E se unir esforços a gente vai alcançar algum objetivo maior com certeza. Eu gostei. 


\title{
Projeto 6 - Retomada de um assunto por um dos participantes
}

O Sr. Mauro ainda retomou o assunto do seu filho, contando que estudou o método do Lair Ribeiro para tentar ajudá-lo, mas não adiantou. Parece que ele resistia ao encerramento do grupo, querendo continuar a discussão.

\begin{abstract}
Mauro: Não se você ouviu falar em Lair Ribeiro.(...)Igual ele costuma dizê. "Precisa de um método fácil, prá se dizer assim, como ensinar as pessoas à estudar.”(...) Eu tô sempre buscando alternativa.
\end{abstract}

Rose: A gente tem mais é que buscar mesmo.

Mauro: Agora a mais difícil tá sendo a do meu filho. (risos) (várias pessoas falando) Você resolve problemas dos outros, mais os seus...

\section{Projeto 7 - Fechamento do grupo e compromisso de sigilo}

Antes da coordenadora fechar definitivamente o grupo, a Rose perguntou se os encontros tinham contribuído para o objetivo da pesquisadora e fez um questionamento sobre o sigilo. A Gisele colocou, ainda, que o grupo é necessário para que os pais consigam reivindicar seus direitos. A coordenadora deu garantia de sigilo e encerrou a sessão.

Rose: A gente qué sabê, né, se adiantou, se não adiantô.(...) Nada disso vai sê falado, igual no amor exigente que ela tava falando. Então vocêis ficam ai falando, falando de coisas daqui da escola e não precisa pensar: 'Ai meu Deus do céu, ela já abriu o bico?' (risos) (várias pessoas falando)

\section{Movimento do grupo- síntese do segundo encontro}

No início do encontro, a coordenadora pediu que os participantes fizessem uma retomada do encontro anterior, com o objetivo de aquecer o grupo para que fosse dada continuidade à proposta. Os integrantes foram colocando as mudanças que já haviam ocorrido no seu modo de perceber os fatos.

O desenvolvimento dessa sessão se caracterizou por uma alternância entre temas genéricos e pessoais, tendo havido várias tentativas, por parte de diversos membros do grupo, de protagonizar sua questão. Nesses momentos, acontecia um aprofundamento 
no tema, para, em seguida, ele ser retomado novamente de forma genérica. Pode-se dizer que houve uma disputa pelo protagonismo grupal. Durante toda a sessão o Sr. Mauro parecia reivindicar essa posição, mas acabou não conseguindo ocupá-la como gostaria, já que até mesmo no encerramento da sessão, ele a trouxe novamente. No entanto, ele teve oportunidade de retomar o relato de sua experiência e sentimentos, confessando o desejo de tirar o filho da escola e mostrando que se sente agredido. Ele parece ter mobilizado no grupo o sentimento de impotência

A Gisele, a Rose, a Rafaela e a Sandra também fizeram relatos pessoais durante a fase de desenvolvimento do grupo, narrando situações sofridas pelas quais passaram na escola dos filhos.

Essas questões conduziram a tentativas de elaboração por parte de alguns integrantes, tendo se destacado a Rafaela, que percebeu que o filho não está sempre errado. Houve, também, uma busca de soluções para os problemas observados, mas sem muito êxito. As soluções apontadas nesse momento foram aquelas já utilizadas e que não trouxeram um resultado efetivo, como falar com a diretora.

$\mathrm{Na}$ fase de comentários, a coordenadora fez a proposta de continuar no levantamento de alternativas às dificuldades apontadas, mas o grupo se voltou ao questionamento das pessoas que não compareceram no encontro. Em seguida, o Sr. Mauro colocou que a escola deveria ter uma maior diversidade de disciplinas e a Sandra sugeriu que fosse feito um grupo de auto-ajuda para os alunos com dificuldades. $\mathrm{O}$ grupo passou, então, à tarefa de definir como seria esse grupo. A Gisele colocou que ele deveria ser para os pais também e o Sr. Mauro ressaltou que não deveria ser apenas para pais de crianças com problemas e que o nome dessas crianças não deveria ser falado para não constranger os pais. Talvez esse relato mostre como ele se sente pelo fato do seu filho ser considerado um problema na escola.

Um outro aspecto trazido pela Gisele, foi a importância de que toda manifestação de críticas à escola seja feita de forma coletiva pelos pais, para que não seja tomada pela escola como algo pessoal.

Ainda antes de fechar o grupo, duas pessoas fizeram reflexões sobre a vida pessoal, além de terem sido trazidas críticas à mãe que faltou do encontro e aos pais que não participam. Alguns integrantes pareciam resistir ao fechamento do grupo, proposto pela coordenadora.

Antes que o encontro terminasse, a Valéria também se colocou, apontando seu incômodo antes não confesso. Assim, observa-se que todos os integrantes tiveram 
espaço para se colocar de maneira pessoal, sendo acolhidos pelo restante do grupo. Ela retomou o tema da escola, apontando sua insatisfação com as aulas de reforço da filha. O Sr. Mauro concordou e a Rafaela também fez um relato sobre o reforço do filho, concluindo que às vezes cobra o filho injustamente.

A coordenadora pediu, então, que os integrantes do grupo fizessem uma avaliação dos encontros. As respostas foram todas positivas, tendo sido colocado que o grupo serviu para que eles descobrissem coisas que ainda não sabiam, como por exemplo que sua dificuldade é compartilhada por outras pessoas (Rafaela, Mauro, Valéria, Rose).

A coordenadora encerou a sessão, afirmando seu compromisso de sigilo, já que esse aspecto havia sido questionado por uma participante do grupo.

Nesse segundo encontro não foram percebidos conflitos sociométricos e, talvez por isso ele tenha funcionado de maneira acolhedora com todos os seus membros. Podese dizer que os antagonismos presentes no primeiro encontro provavelmente foram neutralizados, já que nem a entrada de uma nova integrante provocou uma desestabilização no grupo. Um outro aspecto que pode ser bservado, é que o segundo encontro pareceu ser uma continuidade do primeiro. $O$ primeiro se ocupou principalmente de aspectos sociométricos e do aquecimento para que o grupo entrasse no tema de forma genuína. O protagonismo do grupo surgiu no final do primeiro encontro e pode-se dizer que a elaboração e comentários foram realizados no segundo encontro, onde cada integrante se colocou de forma pessoal. 
Síntese dos resultados das entrevistas em grupo focal

\section{Primeiro Encontro}
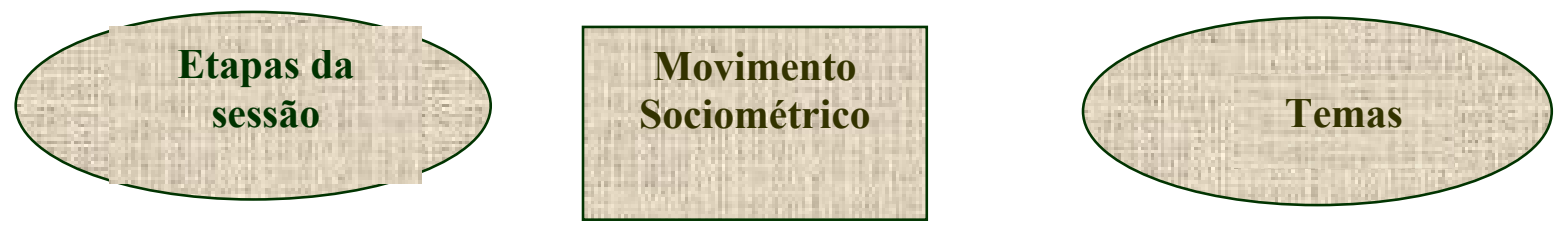

\section{Aquecimento}

Quebra da resistência: Rose Antagonismo: Gisele
Contou que o filho se sente marcado pela vice-diretora

Gisele sai do antagonismo

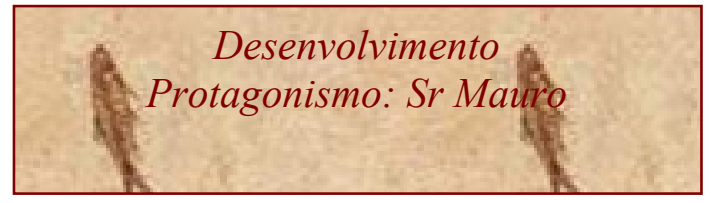

Fechamento

Compartilhar: Rafaela
O filho perdeu quatro dias de aula por causa do uniforme / vivência de discriminação

Relata a percepção de que seu filho também é discriminado

\section{Segundo Encontro}

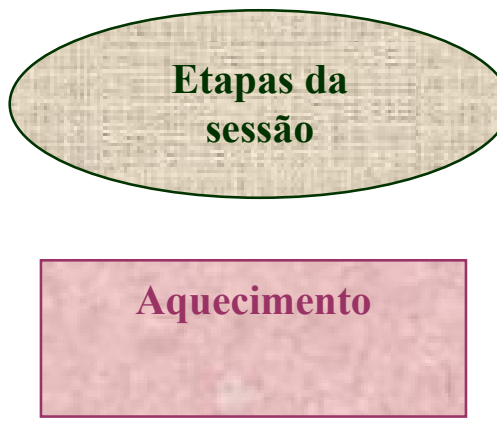

\section{PROTAGONISTA}

\section{Temas}

-confirmação das críticas à escola que apareceram na sessão anterior

-Sr Mauro: não deixará mais o filho perder aula por causa do uniforme

-críticas à vice-diretora 


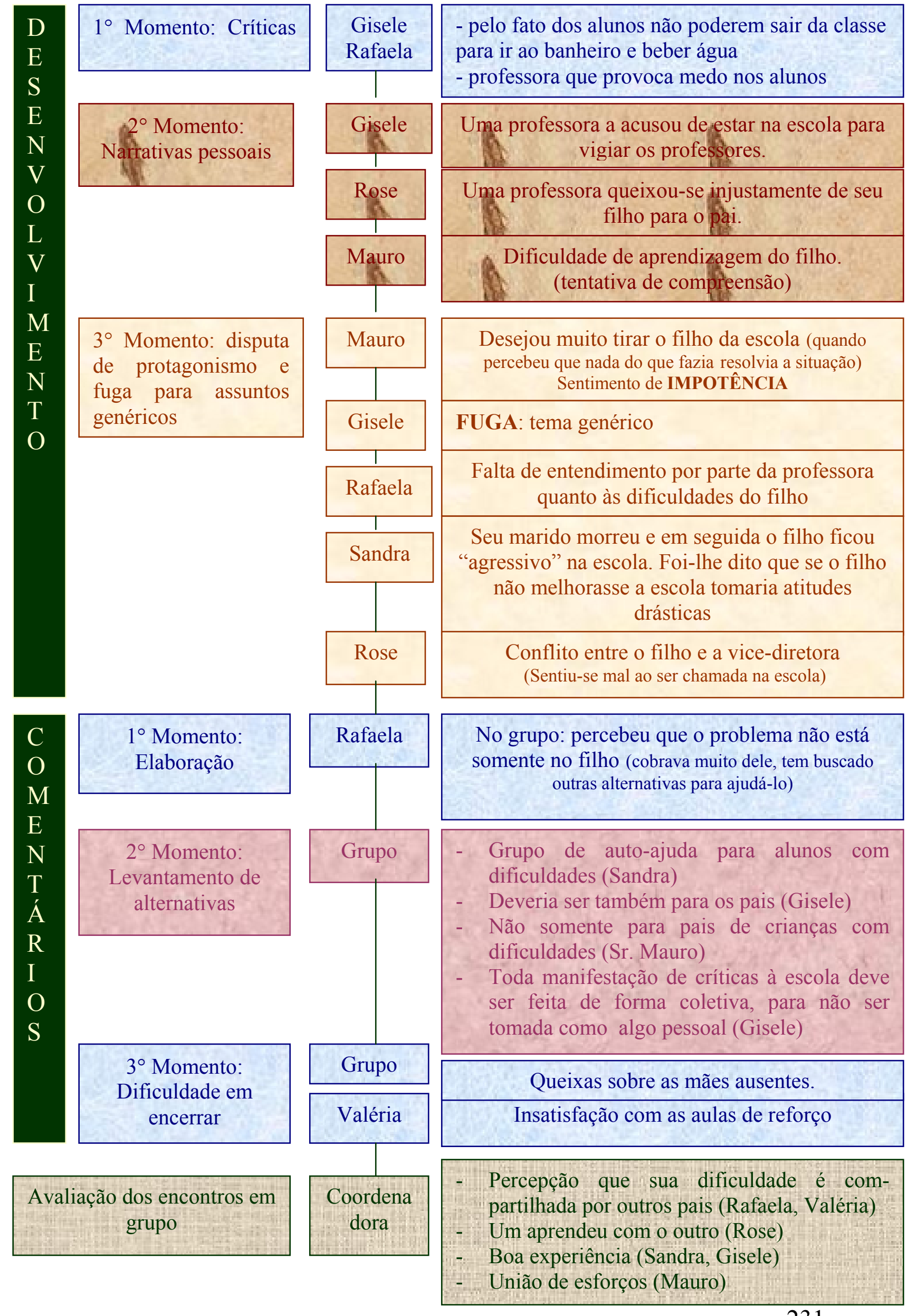




\section{Conclusões acerca das entrevistas em grupo focal}

1 - Especialmente pelo tema abordado nas entrevistas individuais gerar reações tão defensivas, essa estratégia se mostrou importante para a obtenção de dados mais consistentes.

2 - O sentimento de impotência foi compartilhado, revelando que mesmo os pais mais integrados e instituídos guardavam vivências, talvez bem escondidas, já que não foram trazidas nas entrevistas individuais, onde se sentiram inferiorizados ou não puderam ajudar os filhos diante da cobrança da escola.

3 - As críticas, ainda incipientes na entrevista individual, parecem ter sido legitimadas pelo grupo. Os pais se mostraram mais críticos e em busca de melhores soluções para os filhos.

4 - A consciência ampliada a respeito da escola provavelmente fará com que os pais diminuam a pressão sobre os filhos.

5 - Apareceu a necessidade dos pais se organizarem coletivamente para fazerem reivindicações na escola. Consciência de que se não for dessa forma a reclamação é tomada como pessoal. 


\title{
CAPÍTULO IV - DISCUSSÃO
}

\author{
Quem volta do deserto \\ Tem um olhar para sempre \\ "Insatisfeito" \\ Com as aparências \\ Incapaz de idolatria \\ Pois idólatra é quem se satisfaz \\ Com aquilo que vê \\ Com aquilo que compreende \\ Com aquilo que é \\ (Jean-Y Leloup, Deserto, desertos).
}

\begin{abstract}
A escola
A escola, na sua situação particular, se enraíza num contexto mais amplo no qual está inserida, só podendo ser compreendida de forma aprofundada se reconstituído seu cenário social, cultural e histórico. Isso significa explicitar seu local geográfico, suas condições de existência, a organização econômica da cidade onde ela está estabelecida, além de uma caracterização de sua clientela, para que se tenha uma visão sobre o todo.

Trata-se de uma escola estadual, localizada num bairro de periferia, atendendo 1100 alunos, de $3^{\mathrm{a}}$ a $8^{\mathrm{a}}$ séries (em 2001). No seu ambiente físico, observou-se um grande cuidado com a limpeza e organização. As dificuldades apontadas pelas dirigentes foram escassez de recursos e funcionários, sendo solucionadas de forma criativa: projetos envolvendo recursos de escolas particulares e solicitação de ajuda comunitária.

A história da escola é marcada por momentos de aliança com a comunidade, através de movimentos reivindicativos, por meio dos quais obteve-se expansão de recursos materiais, além da construção, na época da municipalização do ensino fundamental, de uma escola no bairro para atender os alunos das séries iniciais, que deixavam de ser atendidos pela rede estadual.

Esse fato foi relatado por vários pais entrevistados que descreveram seu envolvimento na luta para a construção de uma nova escola no bairro, colocando de forma positiva e entusiasmada sua contribuição à comunidade.
\end{abstract}


Assim, observou-se nessa escola um movimento instituinte forte. Ela parece ter se construído no confronto com seus mandantes, buscando o engajamento comunitário como via de obtenção das melhorias necessárias.

De forma geral, os pais destacaram a abertura que essa escola dá às famílias, comparando-a com outras, apontando especialmente a diretora como incentivadora desse movimento.

Diante das carências da escola e as exigências de autofinanciamento das políticas públicas, a diretora se mostrou claramente contrária às prescrições hegemônicas, negando-se a expandir a escola às custas de trabalho voluntário de pais e professores. Ao invés disso, aliou-se à comunidade, utilizando o apoio de radialistas, políticos locais e movimentos reivindicativos.

Observa-se assim que essa escola consegue, por um lado, uma aliança positiva e eficaz com as famílias. Portanto, pode-se dizer que a participação dos pais no contexto escolar parece ser positiva quando solicitada para que se alcancem objetivos comuns, sendo respeitada a diversidade das famílias.

No entanto, ao se analisar alguns documentos da escola, como a proposta pedagógica e o conteúdo de conversas informais com a vice-diretora, coordenadora e professores (registrados em diário de campo), observou-se que a relação com as famílias baseia-se ainda em dois clichês: nas prescrições quanto aos deveres dos pais e no discurso de famílias deficitárias, onde a ênfase é dada no que os pais não fazem.

Parece, então, ser necessária na escola uma reflexão sobre o que está funcionando bem e o que, pelo contrário, não contribui para uma relação positiva com as famílias. As próprias bases norteadoadoras da ação escolar, ou seja, seus documentos oficiais, apesar de trazerem hipóteses sobre as dificuldades, não trazem propostas de ação efetivas, mas repetem os estereótipos. Segundo Patto (1992, p. 117),

[...] os rótulos 'grudam nos dentes' dos oprimidos e funcionam como 'mordaças sonoras' (segundo expressões usadas por J. P. Sartre para se referir à adesão dos colonizados à ideologia do colonizador) que dificultam uma visão crítica de sua condição social e os mergulham num discurso de auto-acusação. 
Assim, parece ser importante promover na escola um diálogo reflexivo entre a prática cotidiana e as bases norteadoras da ação escolar. Essa prática cotidiana, se refletida, pode lançar luz às ações efetivas e àquelas não efetivas, sendo esse processo fundamental para o estabelecimento de metas esclarecidas e estratégias de ação afinadas com a realidade.

Medrado (1998) afirma, no entanto, que a ocupação do tempo dos diretores, professores e técnicos com funções burocráticas, como organização de documentação e preenchimento de formulários, rouba o tempo que seria destinado à reflexão e ao planejamento dentro da escola. A burocracia termina por determinar um modo de funcionamento institucional que dificulta a auto-gestão, ou a gestão democrática.

\section{As famílias}

Quanto às famílias dos entrevistados, observou-se que o modelo tradicional ainda constitui sua maioria, mas a soma das famílias reconstituídas e monogâmicas se aproxima desse número. Sérias dificuldades sócio-econômicas foram observadas principalmente nesse último grupo, quando a mãe exercia sozinha as funções tanto de sustento da família quanto do cuidado dos filhos.

Muitas famílias (15) possuem pelo menos um dos cônjuges provenientes de outras regiões, especialmente do sul de Minas Gerais. Vários vieram da "roça" para a cidade em busca de emprego. Como a cidade é industrial, tem atraído muitos migrantes. Assim, observou-se na história de muitos uma cisão entre aspectos sócio-culturais da família de origem e as vivências atuais, gerando dificuldades quanto aos métodos educativos a serem adotados com os filhos.

As histórias escolares também foram marcadas por rupturas, e até mesmo nos casos em que a escolaridade era mais alta, observou-se que os pais voltaram à escola depois de adultos, quando sua situação sócio-econômica permitiu esse investimento.

O trabalho da maioria dos pais é marcado por uma instabilidade, e as mães que trabalham fora (a maioria das entrevistadas) mostraram viver uma sobrecarga, o que dificulta sua participação na escolarização dos filhos da maneira como gostariam.

Nas famílias em que a situação sócio-econômica se mostrou mais precária, observou-se alguns empecilhos à escolarização dos filhos: necessidade de que eles 
comecem a trabalhar para ajudar na renda familiar e necessidade de que ajudem nas tarefas domésticas. Essas tarefas mostraram atrapalhar o aluno no cumprimento de algumas exigências da escola, tais como pontualidade, organização e freqüência.

No entanto, Zago (2000) já afirmou que nos meios populares as crianças não têm seus dias organizados em torno de atividades escolares, o que é estratégia dos extratos médios da população. Portanto, se a escola não se flexibiliza na cobrança dessas questões, ela irá, invariavelmente, expulsar aqueles que não se enquadram em seu molde.

Os resultados do atual estudo apontaram ainda que falar em "famílias de alunos da escola pública" de forma genérica talvez não seja suficiente para caracterizar bem essa clientela. Observou-se pelo menos três modos de posicionamento diante da escola, que podem estar definindo vivências, práticas e posições diferentes.

Em primeiro lugar, tem-se as mães que participam da vida escolar dos filhos da forma esperada pela escola, acompanhando o filho nas tarefas, participando de festas e campanhas para arrecadar dinheiro, comparecendo a todas as reuniões e algumas vezes até fazendo parte do projeto "amigos da escola". As principais representantes desse grupo estavam todas dentro do modelo tradicional de família, os maridos possuíam trabalho "não-braçal" e sustentavam as famílias.

Observou-se aqui um discurso predominantemente reprodutor da visão hegemônica da escola, pelo menos na entrevista individual. Essas mães só fizeram relatos sobre experiências negativas no contexto grupal. Observou-se em seus relatos a culpabilização de "outras" famílias pelo insucesso escolar dos filhos, discurso que provavelmente revela o desejo de se diferenciarem dos pais criticados pela escola, assegurando assim sua posição de "incluídas".

Nota-se dessa forma o quanto essas mães se colocam de forma submissa diante da escola. No entanto, são elas que possuem algum acesso aos espaços decisórios da instituição (se é que eles realmente ocorrem), como Conselho de Pais e Associação de Pais e Mestres.

Nessas famílias, pareceu ocorrer mais freqüentemente uma aliança entre a mãe e a professora para auxiliar os alunos. Mesmo assim, para conseguir essa aliança, as mães mostraram ter que corresponder ao que delas é esperado.

Já as mães mais críticas na entrevista individual pareceram ter medo de se abrir no grupo, mostrando atitudes defensivas nesse contexto, ou se negando terminantemente 
a participar dessa etapa da pesquisa. Elas pareceram evitar o compartilhar de suas críticas, provavelmente pelo medo do rechaço da escola.

Foi observada ainda uma posição defensiva, assumida pela maioria dos pais entrevistados. Estes, ao serem instigados a falar sobre a escola, realizaram um discurso predominantemente defensivo, dando respostas genéricas, mostrando apoio irrestrito à escola, ou justificando-se pelo que não fazem por ela. Quando fizeram críticas, essas foram vacilantes. Na verdade, na maioria das vezes ocorria uma afirmação próxima ao discurso hegemônico, em seguida era narrada uma situação que deflagrava uma crítica. Após essa tomada de consciência e provavelmente como uma defesa a ela, o discurso hegemônico era retomado. Esse aspecto pode ser exemplificado pela fala da Inês:

\footnotetext{
"Porque, eu, por exemplo, eu num gosto de recramá de ninguém.(...) Só que às veiz, um fio, tem hora que chega e fala: "Mãe, aconteceu isso e isso." Às veiz, mesmo que eu senti magoada, eu entrego assim, pra Deus.(...) Então eu num tenho cumo num falá, assim, dos professor, não. Os professor dai são muito bom, mesmo. Mais são ótima, a escola.(rindo)"
}

Vale notar que nesse último grupo encontram-se os pais com menor grau de escolaridade, estando provavelmente numa condição de maior instabilidade e vulnerabilidade não somente econômica, como social e afetiva.

Sigolo e Lollato (2001) afirmam que os pais enxergam a escola de forma idealizada, ficando contentes quando são elogiados ou introjetando as críticas que ouvem. Esse aspecto foi observado no atual estudo: os pais que se mostraram acríticos na entrevista individual parecem ser aqueles elogiados. Os pais que se justificaram muito, apresentando um discurso mais defensivo, provavelmente são aqueles que introjetam as críticas da escola.

As mães elogiadas tinham um perfil parecido: eram colaborativas e disponíveis. Esse parece, ser, então, o modelo de atuação valorizado pela escola e esperado de todos os pais. No entanto, como ele é impossível para muitos, é gerada uma crítica com relação àqueles que não conseguem agir da maneira esperada. Nota-se que foram freqüentes na escola as críticas às famílias ditas "desestruturadas". Além disso, a ênfase era sempre dada ao que esses pais não estavam fazendo. "Os pais são ausentes, não resolvem os problemas dos filhos, não acompanham sua vida escolar, não se interessam" (Professores).

Os agentes escolares apontaram ainda que um dos problemas da escola é que os pais que "mais precisam" não participam da vida escolar dos filhos (Plano de gestão, 
Diretora). Esses pais são normalmente criticados por não participarem, sem que seja feita uma reflexão mais aprofundada, em termos do que talvez os esteja afugentando, mas também sobre a relevância das expectativas da escola quanto à atuação da família.

Assim, cabe questionar se as prescrições contidas nos documentos oficiais da escola, acerca das funções dos pais, estão verdadeiramente contribuindo com os alunos ou com uma maior eficiência do ensino. Cada uma delas será apresentada e discutida a seguir. A saber, os pais devem (1) passar para os filhos o valor da aquisição de conhecimentos, (2) participar das reuniões, (3) ajudar nas tarefas escolares e (4) apoiar a escola quando houver problema disciplinar (Proposta Pedagógica). É exigido deles, ainda, de acordo com os relatos da diretora, da vice-diretora, da coordenadora e de professores, a participação na escola, aspecto que será também discutido na seqüência.

\section{O valor da aquisição de conhecimentos}

Observou-se que os agentes escolares se queixavam freqüentemente dos pais que, segundo eles, não educam bem os filhos e não valorizam o estudo. No entanto, confirmando o que outros autores (ANDRADE, 1986; CRUZ, 1997; ZAGO, 1998) já apontaram, observou-se um consenso dos pais quanto à valorização da escolarização dos filhos.

Suas justificativas se apoiavam tanto em explicações cognitivas, sendo a escola vista como a única via de ascensão social para os filhos, quanto em vivências que revelam como é ter pouco estudo na sociedade atual.

Os entrevistados destacaram, ainda, a discriminação vivida devido à falta de escolarização e o sentimento de inferioridade por ela causado. Portanto, o fato de não estudar não parece ser uma escolha, mas uma conseqüência de situações inesperadas, que terminam por impossibilitar a permanência na escola.

De acordo com esses resultados, pode-se dizer que os pais já cumprem a expectativa da escola de passar para os filhos a importância da aquisição de conhecimentos, sendo improcedente a afirmação de que eles não valorizam a escolarização dos filhos. 


\section{Reunião de Pais}

Além de ser uma função dos pais, a reunião também é um direito, em prol da gestão democrática da escola (Regimento Escolar). As reuniões estão, portanto, servindo ao seu propósito?

Oliveira (1999) afirma que as reuniões de pais e mestres, ou reuniões para entrega de boletins, onde os assuntos versam sobre comportamento e mau rendimento escolar, acontecem de forma que as pessoas são envolvidas apenas para legitimar as relações sociais já existentes, havendo, por um lado, a cobrança dos professores e, por outro, o afastamento dos familiares.

Segundo Perez (2000) as reuniões funcionam como mecanismo de controle, avaliação, comparação e julgamento do desempenho dos pais. No entanto, de acordo com Cruz (1997), estes não percebem seu caráter de intimidação, nem mesmo quando são repreendidos publicamente.

No atual estudo, a maioria dos relatos dos pais sobre esse tema pareceu ter um caráter defensivo, já que muitos não deixaram transparecer sua opinião ao falarem sobre o assunto. Houve relatos puramente descritivos, outros genéricos. Esse aspecto foi também observado por Chechia (2002), que aponta que os pais têm dificuldades em revelar sua opinião.

Como os poucos relatos avaliativos, quanto a esse tema, foram todos negativos, pode-se dizer que os pais têm dificuldades de expressar sua opinião, principalmente se ela for contrária ao que deles se espera. Eles apontaram que as reuniões são chatas, cansativas e demoradas, gerando desinteresse na maioria.

Portanto, como afirmam outros autores (SIGOLO \& LOLLATO, 2001; PEREZ, 2000; CRUZ, 1997), o fórum instituído na escola para o encontro com as famílias não parece estar cumprindo sua função. "A verdadeira democratização da educação tem mais a ver com a capacidade que a Escola tem em acolher no seu seio, sem gerar exclusão ou descriminação por insucesso escolar, a enorme diversidade social e cultural, que a lei passou a determinar" (SOUSA, 2000, p.2).

\section{Ajuda nas tarefas escolares}

Chechia (2002) observou que tanto pais de alunos com sucesso, quanto os daqueles com insucesso escolar relataram tentativas de ajudar os filhos nas tarefas, 
mesmo mostrando muitas dificuldades de executar essa função. Lahire (1997) também afirma que esse acompanhamento não garante o sucesso escolar.

No atual estudo obteve-se um resultado parecido. Diferentemente do que normalmente é dito pelos agentes escolares, todos os pais entrevistados (que se referiram a esse assunto) mostraram valorizar o acompanhamento escolar dos filhos (cobrança e ajuda na tarefa de casa).

No entanto, muitos pais justificaram-se por não poder cumprir bem essa tarefa devido a outras ocupações e por dificuldades em ensinar os filhos. Vale notar que esse resultado se diferencia do discurso usualmente difundido pela escola, de que os pais não se importam com a escolarização dos filhos, por isso não os ajudam.

Sendo assim, não se pode afirmar que a cobrança de auxílio dos pais nas tarefas é relevante, uma vez que não parece ser um determinante para o sucesso dos filhos. Além do que, os pais relataram grandes dificuldades e constrangimentos decorrentes dessa expectativa da escola.

A literatura da área já trouxe várias críticas a essa prescrição. Zago (2000) critica o fato de a escola desconsiderar que a mobilização familiar nas camadas populares é voltada em primeiro plano para a sobrevivência, não havendo tempo nem recursos disponíveis para esse tipo de investimento escolar.

Além disso, quando se pede esse tipo de ajuda aos pais, desconsidera-se o fato de que muitos deles tiveram pouco acesso à escola, quando não histórias escolares marcadas por rupturas e sofrimento. Lahire (1997) afirma que é preferível ter pais com pouca escolaridade do que pais que sofreram na escola, pois eles comunicam aos filhos, sem que percebam, suas angústias e suas próprias dificuldades passadas.

É importante repensar as prescrições quanto ao trabalho dos pais, pois parece ser a partir do contraponto entre a expectativa da escola, que muitas vezes já está internalizada por eles, e aquilo que efetivamente conseguem executar, que surgem algumas atitudes de desistência. Essas são normalmente vistas pela escola como desleixo e irresponsabilidade, adjetivos com relação aos quais os pais não sabem como se defender. Diante dessa situação, a saída que se mostrou mais comum foi o aumento da pressão sobre o filho, através de ameaças e punições. O resultado dessa atitude já se pode prever: com o aumento da tensão na relação familiar, os filhos, provavelmente já acuados na escola, ficam com possibilidades ainda menores de se desenvolverem. 


\section{A disciplina}

A escola pede aos pais que a apóie quando houver problemas disciplinares. Ligada à exigência desse posicionamento, está a cobrança de um alinhamento ao pensamento hegemônico, principalmente porque as normas de disciplina não parecem ter sido construídas de acordo com a realidade das famílias atendidas pela escola. Elas são fruto do ideário cultural dominante, sendo executadas em nome da normatização da população (CUNHA, 1998).

Aquino (1996) questiona a laicidade do ensino, apontando que a educação atitudinal ocupa um grande espaço no território escolar. Vale notar que a escola, tal como a conhecemos hoje, foi se construindo historicamente, estando sempre ligada aos interesses e valores hegemônicos de cada época.

Segundo Ariès (1978), a partir da Idade Média a escola assumiu uma função moralizadora, devendo criar "bons hábitos" nos alunos. Não se pode negar que a escola de hoje herdou essa característica. Perez (2000) observou que os encontros entre pais e professores ocorrem primordialmente em função de problemas comportamentais.

Andrade (1986) obteve resultados parecidos. Em seu estudo, as famílias dos alunos eram vistas pelos professores como ineficientes para transmitir as concepções de mundo adequadas à criança. Ele observou que na prática docente as ações disciplinadoras eram privilegiadas, às vezes até em detrimento de práticas pedagógicas.

As normas de disciplina estão, portanto, ligadas a um certo tipo de exercício de poder, e os resultados do atual estudo revelaram que as famílias parecem aderir aos valores dominantes. A maioria dos pais que falaram sobre esse tema na entrevista individual mostrou concordar com as normas da escola quanto à disciplina. As poucas críticas foram relativas à maneira como a escola exige seu cumprimento.

No entanto, como os pais questionaram a maneira como as regras são cobradas, é possível inferir que eles dizem sim às normas sem refletirem verdadeiramente sobre elas. Os pais parecem querer, na realidade, uma escola organizada, segura, eficiente. Mas esses quesitos estão ideologicamente atrelados ao uso da disciplina. Medeiros (2004) afirma que o conteúdo das regras disciplinares que se encontram na escola hoje foi construído historicamente, não sendo indispensável à aprendizagem escolar.

A escola estudada exige disciplina, sendo os rituais institucionais muito organizados. No entanto, foram observados dois modos de se exigir seu cumprimento: 
um mais maleável, destacando-se as figuras da diretora e de mães amigas da escola (que exercem função de inspetoras); outro mais rígido e autoritário, representado principalmente pela vice-diretora.

O primeiro modo foi unanimemente valorizado pelos pais, enquanto o segundo foi muito criticado, sendo um dos principais temas das entrevistas em grupo focal. Esse fato suscita a reflexão de que os pais questionam a forma de exercício de poder e não as regras escolares propriamente ditas. Observa-se, no entanto, que quando o caráter da cobrança de disciplina na escola se torna explicitamente correcional e normatizador, alguns pais percebem essa ação como coercitiva e violenta:

"Já, já me chamaram atenção na frente dos pais e eu não gosto. Isso eu acho errado. E não é só a minha não, de muitos pais. Chamam atenção e isso é humilhante, eu acho isso humilhante tanto pra criança quanto prá nós. "(Cibele)

Observou-se que alguns pais se esforçam muito para cumprir as regras e, mesmo assim, isso nem sempre é possível, o que parece gerar um sentimento de vergonha. Diante dessa situação, eles mostraram ter atitudes de desistência, agressividade e afastamento, o que pode ser exemplificado pela fala de Dona Rita:

"Essa (filha) eu tive que tirá ela (da escola). Ela era tupetuda."

Portanto, este parece ser um dos sérios impasses que ocorrem cotidianamente e que vão criando o que pode ser chamado de um mecanismo sutil de exclusão.

Observou-se ainda que a aplicação de algumas normas pareceu ser arbitrária na escola. Um exemplo disso é que, de acordo com o Regimento Escolar, a escola não poderá fazer solicitações que impeçam a freqüência dos alunos às atividades escolares ou sujeitá-los a discriminação e constrangimento.

No entanto, foram relatadas situações em que alguns alunos não freqüentaram as aulas devido à falta do uniforme completo e por causa de atraso. Alguns pais observaram, diante desse fato, a necessidade de uma maior flexibilização da escola com relação às suas normas. Esses relatos foram trazidos principalmente pelas mães amigas da escola, que conhecem a realidade de algumas famílias, pois moram no mesmo bairro, 
e acabam exercendo aí uma importante função de mediação, apresentando à escola essa realidade.

Alguns pais revelaram ainda, algumas das formas como comunicam aos filhos que esperam deles uma atitude de docilidade e submissão, aspecto já apontado por Cruz (1997) e que pode ser exemplificado pela fala da Sandra:

"(sendo) assim um bom aluno e tudo, que procura obedecer, a professora não vai ser agressiva, não vai pegar no pé dele, né." (Sandra)

Aqui parece ocorrer uma aproximação entre escola e família, enquanto instituições sociais com uma função educativa de vigiar e enquadrar a juventude (ARIÈS, 1978). Guimarães (2004) afirma ainda a ocorrência de um ato educativo baseado no princípio de homogeneização, exercido através de atividades que esquadrinham o tempo, o espaço, os gestos, as atitudes, impondo aos corpos uma atitude de submissão e docilidade.

Segundo Foucault (1987), a partir do século XVIII, o corpo passou a ser objeto de investimentos imperiosos e urgentes, devendo ser trabalhado detalhadamente, para que se exercesse sobre ele uma coerção sem folga. Nasceram, então, as disciplinas, que se tornaram a fórmula geral de dominação. Pode-se dizer, assim, que associaram-se num mesmo momento histórico as disciplinas e a arte do corpo humano, com o objetivo de tornar esse último mais obediente e ao mesmo tempo que mais útil. "A disciplina fabrica assim corpos submissos e exercitados, corpos dóceis" (FOUCAULT, 1987, p. 127).

Esse mesmo método foi sendo utilizado inicialmente nos colégios, depois nas escolas primárias e mais tarde nos hospitais e nas organizações militares. Por fim, ele se expandiu, cobrindo o corpo social como um todo.

A disciplina, então, é utilizada para fabricar indivíduos de uma determinada maneira. Para tanto, são utilizados instrumentos simples, um olhar hierárquico e uma sanção normalizadora. Nos sistemas disciplinares a repressão é conseguida por meio de micro-penalidades que são aplicadas de acordo com o uso que se faz do tempo (incidindo sobre descumprimento de prazos, ausências ou interrupções da tarefa), de acordo com o modo como são executadas as atividades (desatenção, negligência e falta 
de zelo), com o comportamento de grosseria e desobediência e com o mau uso do corpo (atitudes incorretas, gestos inadequados e sujeira).

A punição é realizada a partir de processos sutis, não sendo mais um castigo físico, mas privações ligeiras, ou até pequenas humilhações. Esse castigo disciplinar tende a levar o sujeito a exercitar ou buscar o arrependimento, assumindo uma função corretiva, visando reduzir desvios e promover a docilidade, a subordinação e a homogeinização. A partir das disciplinas, pode-se dizer que as instituições passam a funcionar como pequenos tribunais, cuja função é normalizar, o que é conseguido através da utilização que elas fazem dos indivíduos.

\section{A participação dos pais na escola}

Apesar da participação dos pais na escola ser considerada atualmente como fundamental, ela parece estar sendo incentivada somente em termos da ajuda dos pais à escola. Recentemente foi lançada uma campanha, "amigos da escola", realizada por uma grande rede televisiva brasileira a fim de incentivar a população a fazer trabalhos voluntários nas escolas públicas. Sem dúvida, essa é mais uma ação no sentido do autofinanciamento da escola, resultado da política neoliberal e sobre a qual já se observam inúmeras críticas na literatura (DE ROSSI, 2001).

Ainda assim, nessa escola a campanha parece estar funcionando bem, talvez pelo posicionamento explícito da diretora contra o trabalho dos pais na escola, quando este significa uma sobrecarga. Sua relação com as mães pareceu muito positiva, sendo que as "amigas da escola" afirmaram ter tempo, desejo e prazer em executar essa tarefa. Observou-se também que essas mães teriam muito ainda a contribuir com a construção de uma relação positiva entre a escola e as famílias, pois elas se mostraram sensíveis à realidade das famílias a que a escola não parece ter acesso. Elas são, portanto, um grande potencial mediador, podendo atuar como pontes entre a realidade de algumas famílias e a realidade da escola. Além disso, elas mostraram perceber aspectos ocultos do funcionamento institucional, uma vez que convivem nesse contexto. Um exemplo disso é o relato da Gisele, no contexto grupal, em que ela aponta que a vice-diretora manda na diretora (sic) dentro da escola.

Parece que o problema com a prática dos "amigos da escola" se inicia quando esse modelo de atuação passa a ser imposto de forma genérica a todos os pais da escola pública, tornando-se mais um motivo para discriminação daqueles que não podem ou 
não desejam cumpri-lo. Vale notar que os pais entrevistados no atual estudo, que não conseguiam cumpri-lo, justificaram-se por não fazê-lo, o que demonstra que esse modelo de participação já está sendo internalizado, sendo visto como o correto.

Por outro lado, observou-se na escola a exigência desse tipo de ajuda, o que significa uma adesão à política de autofinanciamento da escola pública. Essa posição foi trazida pela vice-diretora e pela coordenadora, tendo sido confirmada sua ocorrência através dos relatos dos pais. Apesar de os pais mostrarem uma visão positiva sobre esse tipo de ajuda, sendo a maneira predominante de sua participação, uma das mães confessou que não ajuda somente porque gosta, mas também para que as professoras não reclamem dela.

Um outro aspecto importante diante dessa questão é a reflexão sobre as conseqüências dessa política. $\mathrm{O}$ fato de poder dar ajuda financeira ou não, tendo que contribuir com trabalho, pode terminar dividindo a clientela da escola em dois grupos. As diferenças sócio-econômicas seriam ainda mais acentuadas no cenário escolar. Além disso, esses pais que teriam que trabalhar na escola ficariam prejudicados em termos de tempo de relação informal com os filhos, aspecto já ressaltado por Carvalho (2000).

Essa ação estaria, então, próxima ao que Lahire (1997) define como uma prática que visa, no fundo, a integração moral e simbólica dos meios populares nas instituições legítimas.

Algumas mães se referiram também à participação em espaços decisórios de poder. No entanto, uma verdadeira participação em tomadas de decisão dentro da escola não pareceu ocorrer. A Gisele, uma das mães "amigas da escola", relatou que foi criticada por uma professora por estar "vigiando a escola" (sic). Carvalho e Vianna (1994) observaram a dificuldade dos professores em aceitar a presença dos pais na escola, apontando que pais e professores ameaçam-se mutuamente devido a uma não delimitação precisa das funções educativas da escola e da família.

De qualquer maneira, cabe questionar se o simples oferecimento de espaço em fóruns de decisão dentro da escola pressupõe uma efetiva participação dos pais nesse âmbito. $\mathrm{O}$ que se observou foi que provavelmente sem o exercício de uma reflexão crítica, os pais acabam reproduzindo a lógica da escola e não conseguem verdadeiramente dar sua contribuição. 


\section{A relação ineficaz entre família e escola}

A Escola ocupa, na sociedade atual, uma posição de destaque, sendo portadora e difusora do conhecimento formal, validado cientificamente e considerado superior àquele proveniente das práticas sociais difundidas pela família (CUNHA, 1998; ANDRADE, 1986).

Houve, assim, uma perda do poder decisório da família no campo educacional, e a escola passou a ter um caráter correcional, sendo a relação família-escola estimulada, com vistas a uma normalização das famílias com padrões indesejáveis. Um modelo ideal de família passou então a ser imposto (CUNHA, 1998).

Observou-se no atual estudo que o conhecimento propagado pela escola é visto e vivido pelos pais como superior ao seu, o que parece levá-los a pensar que não possuem os requisitos necessários para tornar seus questionamentos legítimos. Eles se colocam, na maioria das vezes, de forma submissa e não questionadora, mesmo diante dos descompassos entre as exigências da escola e sua realidade, tecendo, nessas situações, várias justificativas para suas dificuldades. Quando os filhos apresentam problemas de aprendizagem ou comportamento, a pressão na relação com a escola parece aumentar a tal ponto que a reação comum parece ser a desistência.

Uma das mães, ao ficar descontente com o tratamento dado à filha na escola, afirmou que não reclamaria nunca. Pode ser que essa solução seja, para alguns pais, a única possível dentro do universo em que vivem. E não parece significar um descaso com a escolaridade dos filhos, mas uma impotência em lidar com alguns conflitos e exigências que vivem na escola.

Atualmente, o fracasso escolar é visto pela escola como conseqüência de dificuldades do aluno e da família. (CARVALHO \& VIANNA, 1994; ZAGO, 1998; LAHIRE, 1997; SIGOLO e LOLLATO, 2001). Campos (1995) observou que mesmo após a realização de uma intervenção com os professores, a culpabilização da família e do aluno pelo fracasso se manteve.

Essa visão parece ter sido introjetada por muitos pais entrevistados, gerando-lhes normalmente um sentimento de culpa. A maioria deles atribuiu toda dificuldade escolar aos alunos, havendo uma reprodução da lógica meritocrática impregnada na cultura escolar. Somente em alguns relatos observou-se a visão de que a escola e o professor também podem ser responsáveis pelas dificuldades dos alunos. 
Observou-se ainda que são comuns as tentativas de explicação das dificuldades dos filhos por meio de fatores extra-escolares, destacando-se aqui a crença de que a criança é portadora de algum problema orgânico, aspecto também verificado por Andrade (1986) e Chechia (2002).

A escola, por sua vez, parece se relacionar com as famílias prioritariamente no sentido de uma exigência de complementaridade com relação a suas expectativas e através da atribuição de responsabilidade aos alunos por suas próprias dificuldades. Não parece haver um movimento sistemático no sentido de se buscar compreender a realidade vivida pelos alunos e suas famílias. Assim, a escola complementa, através da assunção de um papel social estereotipado, em que a hierarquização do saber é mantida, a postura submissa e não verdadeiramente participativa dos pais. Também Andrade (1986), Aquino (1997) e Perez (2000) observaram um padrão de verticalidade presente nas escolas que estudaram.

Logo, a fórmula família-escola, da maneira como vem sendo empregada na realidade, acaba perpetuando a dinâmica de exclusão das classes populares (ou parte delas) da escola pública, ainda que esse mecanismo ocorra, atualmente, de forma mais sutil. Além disso, a assimetria na relação família-escola é ao mesmo tempo negada, mas também utilizada na manutenção das relações tais como estão acontecendo na realidade institucional. Ao negar essa assimetria, a escola termina assumindo seu local de poder, estabelecendo uma relação estereotipada com os pais, sem conseguir, no entanto, uma aliança eficaz.

\section{As conseqüências para a criança}

Observou-se que tendo sido esgotados os recursos que os pais conhecem para responder às exigências da escola, eles passam a culpar os filhos por não cumprirem suas expectativas, o que usualmente gera conflitos também na relação familiar. Assim, quando a criança efetivamente fracassa na escola, especialmente aquelas provenientes das famílias cujos pais já se sentem excluídos, sua possibilidade de inclusão social fica muito pequena. Isso porque nos dois ambientes onde ela passa a maior parte do tempo, constituindo sua matriz social, a relação passa a ser predominantemente conflituosa. 
Verificou-se ainda que a ajuda dos pais parece ser cobrada de forma mais intensa quando o filho não aprende ou se comporta mal. Alguns pais mostraram sentirem-se envergonhados diante dessa situação e, para resolvê-la, apontaram que só conhecem um método: bater nos filhos. Quando se convencem de que não conseguiram melhora, alguns deles encontram como alternativa tirar o filho da escola. Alguns entrevistados se queixaram de que nem isso podem mais fazer porque "seriam presos". Esse aspecto revela o sentimento de impotência que esses pais vivem ao serem cobrados pela escola. Sua reação, então, ao invés de promover ajuda, parece ser somente aumentar a pressão sobre os filhos.

Já a escola, dependendo do julgamento que faz da família, mostrou estabelecer um tipo de ajuda à criança, mais ou menos eficaz. No entanto, esses julgamentos não parecem ser estabelecidos a partir da investigação da realidade, gerando, na verdade, equívocos. Esse aspecto pode ser exemplificado através dos relatos dos pais acerca do reforço escolar. Os entrevistados explicaram que não permitem a ida dos filhos ao reforço, pelo fato de ele acontecer à noite e o bairro ser perigoso para as crianças irem e virem sozinhas.

$\mathrm{Na}$ escola, foi comum a pesquisadora ouvir dos agentes escolares a queixa de que os pais não se importam com o estudo dos filhos, pois não os trazem no reforço. Essas famílias são, então, vistas como desleixadas, o que reforça a crença na hipótese de que seus filhos, por esse motivo, não têm mesmo condições de aprender. Essa crença, por sua vez, pode levar a uma desistência por parte da escola com relação àquele aluno.

Os pais, de outro lado, parecem manter-se em uma postura passiva, sem mostrar à escola sua perspectiva e suas necessidades. Assim, a escola continua cega à realidade de vida de seus alunos, o que lhe impede a elaboração de estratégias adequadas e específicas para a população que atende.

\section{O papel dos professores}

Os pais entrevistados relataram vivências positivas com professoras, consideradas por eles calmas, carinhosas, atenciosas e dispostas a conversar com os filhos e com as mães. Já as vivências negativas foram relativas às situações onde o filho foi subjugado ou desqualificado pela professora. $\mathrm{Na}$ visão dos pais, a professora deve ser acolhedora às dificuldades extra-escolares dos alunos. Observa-se, portanto, que os 
pais mostraram valorizar, antes mesmo da função pedagógica da professora, o estabelecimento de uma relação afetiva, facilitando a inclusão social do aluno. Vale notar que Sigolo e Lollato (2001) também observaram que para os pais a afetividade é vista como um quesito essencial na relação professor-aluno.

Observa-se que já há algum tempo, na Europa, esse modelo de relação professor-aluno, solicitado pelos pais entrevistados, vem sendo defendido como o mais adequado: "Em uma recente conferência do Conselho da Europa sobre educação, a importância crescente do papel social do professor foi enfatizada" (The Folkeskole, primary and lower secondary education in Denmark, Ministry of Education, 1988, p. 19).

De acordo com esse documento, a explicação para essa prescrição são as mudanças recentes no mundo da criança. Muitas mulheres atualmente trabalham fora, tendo menos tempo para o cuidado com os filhos, o que leva à necessidade de uma atenção maior por parte da escola. Deve-se, assim, buscar uma intimidade da criança com a figura do professor, "Os professores devem se enxergar mais como mediadores do que como doutrinadores ou didatas. [...] Professores da pré-escola, com o peso de seu treinamento social estão oferecendo modelos úteis ao novo papel sócio-pedagógico do professor primário" (p. 19).

Apesar da conveniência da visão dos pais sobre o papel dos professores, sabe-se que no Brasil as condições para que o professor exerça essa função na escola pública são precárias. No entanto, apesar de todas as adversidades, o que se observou no atual estudo é que alguns professores já conseguem estabelecer uma aliança eficaz com os alunos e suas famílias, exercendo, a sua maneira, essa função social.

\section{O representado e o vivido}

Observa-se, a partir da análise das representações dos pais, que o ideário cultural propagado pela escola parece coincidir freqüentemente com a visão de mundo dos pais. Portanto, no nível das representações e crenças, eles mostraram concordar com a escola, o que talvez seja o substrato que mantém, pelo lado dos pais, a relação de poder, tal como ela se configura hoje. No entanto, o universo de vivências das famílias ainda 
permanecia desconhecido e, para investigá-lo foram realizadas as entrevistas em grupo focal.

É importante ressaltar que a postura defensiva observada em grande parte dos entrevistados, ao serem incitados a falar sobre a escola ou de assuntos relativos a ela, não ocorreu quando falaram sobre a família, na etapa de contextualização, realizada antes da parte temática, durante a entrevista individual.

Esse aspecto já havia sido observado quando realizadas as entrevistas-piloto no início da coleta de dados. Observou-se que os assuntos relativos à família deixavam o entrevistado mais à vontade, quebrando o gelo inicial e aproximando-o da pesquisadora. Mesmo tendo havido o cuidado de se iniciar todas as entrevistas pela contextualização familiar, quando se passava à parte temática, vários entrevistados buscaram esquivar-se de um real posicionamento, havendo uma nítida diferença na sua forma de responder.

Observou-se ainda na maioria dos entrevistados, uma atitude defensiva diante dos próprios sentimentos negativos relativos a sua vivência com a escola do filho. Esse fato pode estar indicando um receio generalizado de se efetuar críticas à escola.

Sigolo e Lollato (2001) verificaram que os pais sentem dificuldades de relatar vivências ocorridas na escola dos filhos. Perez (2000) e Andrade (1986) também observaram em seus estudos, que os pais de escola pública tinham um comportamento passivo e resignado diante da escola. No atual estudo também se verificou que a maneira como lidam com as situações de impasse na escola pareceu ser, na maioria das vezes, pouco crítica.

Dessa forma, as entrevistas em grupo focal foram fundamentais no acesso às representações dos pais sobre a escola, no sentido proposto por Penin (1993), onde o vivido (e não somente o representado) necessita ser apreendido. Especialmente pelo fato de o tema abordado nas entrevistas individuais ter gerado reações tão defensivas, essa técnica se mostrou importante para a obtenção de dados mais consistentes.

Verificou-se que as críticas, ainda incipientes na entrevista individual, foram legitimadas pelo grupo, fazendo com que fossem explicitadas, o que colocou os pais em busca de melhores soluções. O sentimento de impotência foi compartilhado, revelando que, mesmo aqueles pais mais integrados e instituídos em relação à escola, guardavam vivências, talvez bem escondidas, em que se sentiram inferiorizados ou não puderam ajudar os filhos diante da cobrança da escola. 
Além disso, a consciência ampliada dos pais a respeito da escola provavelmente fará com que diminuam a pressão sobre os filhos, buscando melhores soluções. Os pais chegaram à conclusão, ainda, de que precisam se organizar coletivamente ao fazerem reivindicações na escola. Talvez pela percepção, agora consciente, de que se não for dessa forma, a reclamação é tomada como pessoal.

Observa-se, assim, que por meio das entrevistas em grupo focal, as vivências dos pais na escola, não elaboradas e portanto não conscientes, foram sendo representadas, ou melhor, reapresentadas na teia do processo grupal. Ali elas tomaram um corpo, ao mesmo tempo pessoal e particular, mas tecido na trama coletiva.

\section{A natureza do grupo}

Apesar de a proposta inicial ter sido a aplicação das entrevistas em grupo focal, nas bases descritas por Vaughn, Schumm \& Sinagub (1996), observou-se que a utilização do psicodrama na condução do grupo acarretou uma mudança na sua natureza. Obteve-se não somente dados relativos às representações dos pais, mas verificou-se, sobretudo, uma mudança em suas concepções, o que caracteriza uma proposta interventiva. Isso ocorreu porque os entrevistados, tendo sido aquecidos para entrar no contexto grupal, apresentaram um nível diferente de comunicação. A dor comum foi, então, revelada.

No contexto grupal, houve uma mudança na postura dos pais, se comparada às posturas na entrevista individual. O Sr. Marcos, um pai mais defensivo no primeiro contexto foi protagonista no segundo. A Rafaela, acrítica no princípio, tornou-se mais crítica após a exposição do Sr. Marcos. Assim, o grupo parece ter promovido abertura e conscientização das mães mais integradas e, também, a inclusão dos mais vulneráveis, tendo tudo isso acontecido em um único movimento grupal.

Vale notar que o Sr. Marcos, no início da segunda sessão, já afirmou que não permitiria mais que o filho perdesse aulas por causa do uniforme. A Rafaela também relatou que a partir dos encontros grupais, percebeu que cobra muito o filho, confessando estar em busca de novas maneiras para ajudá-lo.

Assim, o grupo psicodramático, sendo um método que leva a uma genuína reflexão sobre as vivências ocultas (ideologicamente), parece conduzir a uma desalienação, no sentido descrito por Naffah Neto (1997). 
Segundo esse autor, o verdadeiro aquecimento do grupo promove um estranhamento das concepções conservadas, ou ideológicas. Ocorre, então, uma abertura ao novo, ao incriado. O objetivo é liberar a espontaneidade criativa, definida por Naffah Neto $(1997$, p.49) como

[...] a capacidade de reconquistar, pela ação, a relação de interioridade e de sentido que caracteriza a relação sujeito-mundo.[...] a espontaneidade consiste sobretudo numa capacidade de se abrir perceptivamente, alargando seus horizontes.[...] é reconquistar-se como parte integrante e atuante na situação; é fazer-se uma presença.

Esse autor afirma que essa concepção de espontaneidade pressupõe uma relação de compromisso (no sentido merleaupontiano do termo) e não um ajustamento ou adequação à realidade. Ela ocorre quando acontece uma parada na ação automática e se vislumbra uma nova significação da situação. Nesse instante, cada sujeito recupera sua maneira única de inserção no mundo, podendo agir por sua sponte - livre vontade.

Ocorre um reconhecimento atento da situação, havendo a recuperação do passado conforme as solicitações do presente, não para repetir palavras já ditas, mas para dizer palavras nunca ditas.

\footnotetext{
E se a ação espontânea é uma ação mais livre e menos determinada do que a ação automática é, sem dúvida, porque, em vez de repetir o passado de uma forma inconsciente, ela conscientemente o recupera e o transforma em função do momento presente (NAFFAH NETO, 1997, p. 57).
}

Esse autor afirma que o poder catalizador da espontaneidade consiste numa consciência corporal, a vivência em um corpo percipiente e agente. É, portanto, com esse fim que são realizadas as estratégias de aquecimento no grupo psicodramático.

Em um estudo realizado anteriormente (RIBEIRO, 2000), onde se utilizou a mesma abordagem de condução grupal, a pesquisadora observou que a liberação da espontaneidade só é possível quando as questões sociométricas são elaboradas e flexibilizadas dentro do grupo.

Dessa forma, o objetivo do aquecimento grupal, no atual estudo, foi exatamente dar vazão às questões sociométricas, elaborá-las e, em seguida, resgatar o passado em um corpo em ação, para então conduzi-lo ao presente, ao tema da pesquisa. Buscava-se 
assim adentrar o universo dos não-ditos, das vivências contraditórias, não elaboradas, latentes.

Mas essa abertura espontânea pode levar a um ato criador, a uma transformação no modo de inserção do sujeito na realidade, uma vez que o corpo em ação apreende sentidos antes ocultos à consciência.

A ideologia, no sentido proposto por Naffah Neto (1997), é aquilo que mascara a verdade das relações sociais, acobertando o sistema instituído. O sujeito, ao tornar-se presente na situação e compreendê-la a partir de uma relação de interioridade, conseguida através da ação, se desaliena. É revelada a verdade coletiva tal como emerge espontaneamente na especificidade cotidiana de cada um. O sujeito toma então as rédeas de sua própria existência, podendo reposicionar-se diante do mundo. Ocorre assim uma transformação.

Verificou-se, então, que o grupo, conduzido dentro da proposta psicodramática exposta acima, invariavelmente se torna uma estratégia de intervenção e não somente de coleta de dados. Observou-se que a natureza do grupo se alterou no decorrer do processo, tendo ido além do que era esperado no início do estudo, quando o psicodrama deveria ser utilizado somente como um recurso para o aprofundamento das entrevistas em grupo focal.

Esse resultado revela, ainda, que esse modo de condução grupal pode ser muito útil, não somente no trabalho com famílias, mas também para facilitar mudanças no contexto escolar, na medida em que pode promover um processo de desalienação nos agentes escolares. 


\section{CAPÍTULO V - CONCLUSÃO}

[...] toda uma gama de teorias críticas sugere que é com aqueles que sofreram sentenciamento da história - subjugação, dominação, diáspora, deslocamento - que aprendemos nossas lições mais duradouras de vida e pensamento. Há mesmo uma conviç̧ão crescente de que a experiência de marginalidade social - como ela emerge em formas culturais não-canônicas - transforma nossas estratégias críticas. Ela nos força [...] a lidar com a cultura como produção irregular e incompleta de sentido e valor, freqüentemente composta de demandas e práticas incomensuráveis, produzidas no ato de sobrevivência social (BHABHA, 2003, p. 240).

A partir dos resultados do atual estudo, verificou-se que no nível das representações, o que é desejável à escola é igualmente desejável à maioria das famílias. Existe um modelo idealizado de família que é cultuado e exigido pela escola e, ao mesmo tempo, os pais entrevistados mostraram tentar se encaixar nele.

Nessa tentativa, destacam-se os bem-sucedidos e os mal-sucedidos. Os primeiros reafirmam o ideal, criticando os segundos. Esses últimos pareceram se posicionar em um continuum que variava entre o abandono do desejo de se adequar ou a luta constante nessa direção.

Observou-se, no entanto, que esse investimento pela inserção e adequação parece acontecer às custas de pressão e, muitas vezes, de condutas violentas para com os filhos, o que não tem qualquer correlação com uma efetiva melhora no quadro de dificuldade de aprendizagem. Pelo contrário, acuados em casa e na escola, suas possibilidades de desenvolvimento no âmbito escolar ficam ainda mais limitadas.

Os pais que abandonam o desejo de se adequar parecem ser aqueles que a escola costuma rotular como desleixados e irresponsáveis. Não seriam esses ainda, os tidos como aqueles "que mais precisam" e que estão longe da escola? Mas do que precisam? Ir às reuniões de pais, acompanhar as tarefas, passar para o filho o valor da aquisição de conhecimentos, dar apoio à escola quando houver problema disciplinar? Ou participar da escola com trabalho voluntário e ajuda financeira?

Observa-se que essa aliança instituída entre a escola e a família não é eficaz. 
Mas é fato que nessa escola ocorrem, também, alianças que se mostraram eficazes, ocorrendo "na surdina" do movimento institucional, o que pode ser considerado instituinte na relação entre família e escola. A principal protagonista desse movimento pareceu ser a diretora. Mas cabe ainda questionar se essa aliança pode, sozinha, modificar a situação da escola pública brasileira e seu alto índice de produção de fracasso escolar.

De acordo com os resultados obtidos no atual estudo, a resposta parece ser negativa. As mães que estão dentro da escola se mostraram acríticas e despreparadas para utilizar bem seu espaço. Sem que possam refletir sobre as próprias vivências, elas acabam repetindo o padrão ideológico.

Por outro lado, elas são um grande potencial mediador entre a escola e as famílias "que mais precisam", pois mostraram acessar facilmente a realidade dessas famílias, podendo ser iniciadoras de um movimento de flexibilização das expectativas da escola quanto a elas. Assim, aquelas mais vulneráveis, provavelmente excluídas, podem ir aos poucos se aproximando da escola. Até porque o que se verificou nesse estudo foi que alguns pais se sentem extremamente ameaçados no ambiente escolar, afinal o caráter da aproximação entre a escola e as famílias é predominantemente correcional.

De qualquer maneira, essa escola dá abertura aos pais, se comparada a outras escolas públicas. E talvez por isso este estudo tenha podido ganhar uma certa profundidade: a escola teve pouca resistência em se abrir e se deixar conhecer. No entanto, observa-se a necessidade de uma reflexão aprofundada quanto às praticas eficazes e aquelas que estão gerando, de fato, afastamento e exclusão. As funções instituídas dos pais precisam ser revistas, assim como o caráter correcional na cobrança das normas disciplinares.

Vale notar ainda que os agentes escolares também funcionam de acordo com a ideologia que mantém encoberta a realidade, impedindo a ação crítica. É importante, então, que eles tenham oportunidade de refletir (na ação) sobre suas vivências e práticas, para que possam utilizar melhor a aliança com as famílias. 


\title{
CAPÍTULO VI - APLICAÇÕES PRÁTICAS DO ATUAL ESTUDO : PROJETO DE INTERVENÇÃO
}

\author{
“(...) Ai daqueles e daquelas que, em \\ lugar de visitar de vez em quando o \\ amanhã, o futuro, pelo profundo \\ engajamento com o hoje, com o aqui \\ e com o agora, se atrelem a um \\ passado, de exploração e de rotina" \\ (Paulo Freire).
}

A integração família-escola, acontecendo nos parâmetros descritos, não parece atingir os objetivos que dela se espera e, diante disso, os resultados do atual estudo apontam, no mínimo, duas questões a serem trabalhadas numa possível intervenção na instituição.

A primeira delas seria no sentido de facilitar a desalienação dos pais, ou seja, criar condições para que suas vivências emerjam e sejam elaboradas, para que eles possam construir um panorama sobre o que necessitam verdadeiramente da escola. Acredita-se que talvez assim eles possam ir constituindo voz própria, chegando a ser uma contrapartida às práticas instituídas, tornando-se sujeitos na relação com a escola.

A outra via de trabalho na instituição seria no sentido de facilitar o movimento instituinte, com vistas a desnaturalizar as práticas hegemônicas e promover uma abertura dos papéis sociais cristalizados. Acredita-se que assim os agentes escolares poderiam se aproximar mais da população que atendem, o que facilitaria a criação de estratégias efetivas para a resolução das dificuldades vividas no cotidiano escolar.

No entanto, o primeiro passo, antes da proposta mencionada acima, seria verificar o grau de resistência da escola à mudança, para que as estratégias a serem utilizadas pudessem ser delimitadas. Além disso, faz-se necessário um conhecimento maior sobre as representações das famílias feitas pela escola, para que a relação famíliaescola possa ser abordada em sua totalidade, pois o que se conhece até o momento é prioritariamente a perspectiva dos pais.

Então, será proposto à escola, numa palestra inicial de sensibilização sobre as necessidades de uma maior integração com as famílias, que se inicie um grupo com vistas a refletir melhor sobre esse tema. Serão convidados a participar, professores, diretores e coordenadora pedagógica, e será afirmada a não obrigatoriedade de adesão. 
O objetivo será, a partir dessa reunião, montar um grupo reflexivo com os agentes escolares interessados, o qual ocorreria na Hora de Trabalho Pedagógico Coletivo $^{14}$ (HTPC).

Acredita-se, partindo de uma perspectiva psicodramática, que somente com o contexto grupal construído é que o grupo pode funcionar de forma a facilitar a expressão de conteúdos latentes, presentes nas vivências dos indivíduos. Para tanto, é necessário que haja um bom aquecimento, além da flexibilização das questões sociométricas, antes que se entre no tema propriamente dito.

Conduzido da maneira exposta acima, o grupo parece ser um recurso importante, podendo ser utilizado não somente para a investigação das vivências dos atores sociais, mas também para produzir mudanças, visando a abertura dos participantes a um novo posicionamento diante da realidade. Pode emergir, então, o sujeito espontâneo, capaz de criar novas possibilidades de existência.

Portanto, na atual etapa do projeto, buscar-se-á identificar os limites do envolvimento da escola com as famílias e, ao mesmo tempo, promover a criação de estratégias para uma maior aproximação entre essas duas instâncias. Vale ressaltar, no entanto, que qualquer plano de ação deverá ser gestado dentro do próprio grupo, não devendo ser imposto pela pesquisadora. De forma sucinta, pode-se dizer que sua função como coordenadora do grupo será a de facilitar a construção do contexto grupal, através da utilização de estratégias de aquecimento, com vistas a tornar a sociometria do grupo favorável, a fim de que ele se torne autogestivo.

\footnotetext{
${ }^{14}$ A própria diretora já solicitou, outrora, que a pesquisadora fizesse um trabalho com os professores. Por isso, é provável que esse espaço possa agora ser utilizado para iniciar a intervenção com os agentes escolares.
} 


\title{
POST SCRIPTUM
}

\begin{abstract}
"De sábado aqui nóis liga o som e nóis dança tudo, aqui (...). Eu sô uma pessoa alegre, assim, extrovertida, sabe? Eu num tenho tristeza, sabe?(...) Eu já levanto 5 hora da madrugada, já tô lavano isso daqui, já tô subiano, já to gritano cas galinha.(...) Dô uma gerardada aqui e pronto, sabe? Eu num tenho tristeza não.(...) Se tô cum fome, ponho um prato e como aquilo tudo(...). Quando vejo já cabei meu serviço, aí fico forgadinha (riso). Aí de tarde eu sento, tomo ar puro" (Dona Rita).
\end{abstract}

No contato com algumas das pessoas que encontrei no campo de pesquisa, pude intuir a presença de uma outra lógica, difícil de ser traduzida em palavras, talvez por ser uma lógica de ruptura. Quase imperceptível. Tão distante do discurso, que talvez eu só possa expressá-la, no momento, por meio de imagens.

As fotos presentes no atual estudo significam, assim, uma tentativa de reconstrução de algumas das cenas vividas no contato com os participantes, tendo sido produzidas com arte e sensibilidade pelo fotógrafo e psicodramatista João Henrique Steffen. Também a capa deste trabalho, que tanto traduziu minha vivência, foi feita pela irmã e publicitária Fernanda de Figueiredo Ribeiro. Foram apresentadas, ainda, algumas fotos de Marcelo Greco, retiradas do folder da exposição "Íntima Luz", realizada de dezembro a janeiro de 2003, na Pinacoteca de São Paulo- SP.

Ao lado da carência,

Da opressão,

Da expectativa limitada;

Uma alegria sem motivo;

Um acolhimento gratuito;

O sorriso no avesso da pobreza.

Que me fez perceber que o que busco não está lá, nem cá.

Mas Aqui.

Olhai os lírios do campo.

Eles não trabalham, nem fiam... 


\section{REFERÊNCIAS BIBLIOGRÁFICAS ${ }^{15}$}

Akkari, A. J. (2001) Desigualdades Educativas Estruturais no Brasil: entre Estado, privatização e descentralização. Revista Educação e Sociedade. Campinas, V. 22, N. 74, p. 81-103.

Andrade, A. S. (1986) Condições de vida, potencial cognitivo e escola: um estudo etnográfico sobre alunos repetentes da $1^{\mathrm{a}}$ série do $1^{\mathrm{o}}$ grau. Tese (doutorado), Universidade de São Paulo, São Paulo.

Andrade, A. S. (acesso em: janeiro/ 2004). Sociodrama Educacional: uma estratégia de pesquisa-ação em psicologia escolar institucional. Disponível em: http://gepsed.ffclrp.usp.br/.

André, M. E. D. A (1994) Etnografia da prática escolar. São Paulo: Papirus.

Aquino, J. G. (1996) Confrontos na sala de aula: uma leitura institucional da relação professor- aluno. $2^{\text {a }}$ edição. São Paulo: Summus Editorial.

Aquino, J. G. (1997) A indisciplina escolar: problema da criança, da família ou da escola? Pediatria Moderna, V. XXXIII, N. 5, p. 316-319. Guanabara.

Ariès, P. (1978) História social da criança e da família. Rio de Janeiro: Editora

Bardin, L. (1977) Análise de conteúdo. Lisboa: Edições 70.

Bhabha, H. K. (2003) O local da cultura. Belo Horizonte: Editora UFMG.

Biasoli-Alves, Z. M. M. (1998) A pesquisa psicológica - análise de métodos e estratégias na construção de um conhecimento que se pretende científico. In: ROMANELLI, G.; BIASOLI-ALVES, Z. M. M. (org.) Diálogos Metodológicos sobre Prática de Pesquisa. Ribeirão Preto: Legis Summa, p.135-157.

Bilac, E. D. (1995) Sobre as transformações nas estruturas familiares no Brasil. Notas muito preliminares. In: RIBEIRO, I. e RIBEIRO, A.C.T. (org.) Família em Processos Contemporâneos: inovações culturais na sociedade brasileira. São Paulo: Loyola, p. 43-61.

Boff, L. (1999) Saber cuidar. Petrópolis: Vozes.

Buber, M. B. (1974) Eu e Tu. 2a edição. São Paulo: Editora Moraes.

Campos, N. M. A S A. (1995) O Insucesso Escolar: um estudo sobre as condições e concepções existentes nas instituições família e escola. Dissertação de Mestrado, Universidade de Campinas, Campinas.

${ }^{15}$ As referências bibliográficas seguem as normas de publicação da APA (4ª edição, 1994), já que essas são comumente adotadas nas publicações em revistas científicas da área. 
Carraro, P. R. (2002) Crenças e representações dos professores sobre o construtivismo, parâmetros curriculares nacionais (PCN) e as inovações pedagógicas, no contexto das diretrizes propostas para o ensino fundamental a partir da nova LDB. Dissertação de Mestrado. FFCLRP- USP, Ribeirão Preto.

Carvalho, M.P., Vianna, C. P. (1994) Educadoras e Mães de Alunos: Um (des)encontro In: BRUSCHINE, C.; SORJ, B. (Org.) Novos Olhares: Mulheres e Relações de Gênero no Brasil. São Paulo: Fundação Carlos Chagas, p. 133-158.

Carvalho, M. E. P. (2000) Relações entre Família e Escola e suas Implicações de Gênero. Cadernos de Pesquisa, N. 110, julho, p. 143-155.

Carvalho, M. P. (2001) Estatísticas de Desempenho Escolar: O Lado do Avesso. Revista Educação e Sociedade, Campinas, V. 22, N. 77, Dezembro, p. 231-252.

Chauí, M. H. (1999) Uma ideologia perversa: explicações para a violência que impedem que a violência real se torne compreensível. Folha de São Paulo , 14/ março.

Chechia, V. (2002) A. Pais de alunos com sucesso e insucesso escolar: percepções da escola, do desempenho escolar e do envolvimento com o cotidiano escolar. Dissertação de mestrado, Faculdade de Filosofia, Ciências e Letras de Ribeirão Preto / USP, Ribeirão Preto.

Cruz, S. H. V. (1997) Representação de escola e trajetória Escolar, Psicologia USP, São Paulo, V. 8, N.1, p. 91-111.

Cunha, M. V. (1998). O Discurso Educacional Renovador no Brasil (1930 1960): estudo sobre as relações entre escola e família. Tese (livre-doc.), Faculdade de Ciências e Letras da UNESP, Araraquara.

D’Ávila, J.L.P. (1998) Trajetória Escolar: Investimento Familiar e Determinação de Classes. Educação e Sociedade, Campinas, V. 19, N.62, p. 31-63.

De Rossi, V. S. (2001) Desafio da Escola Pública: Tomar em suas mãos seu próprio destino. Caderno CEDES, Campinas, V. 21, N. 55, novembro, p. 92-107.

Dias, M.L. (1995) Divórcio e Reconstituição familiar no Brasil. In: Reunião Anual da ANPOCS, 19 (mimeografado).

Ezpeleta, J.; Rockwell, E. (1989) Pesquisa participante. São Paulo: Cortez.

Figueira, S. A. (1987) O "moderno" e o "arcaico" na nova família brasileira: notas sobre a dimensão invisível da mudança social. In: FIGUEIRA, S. A. (org.) Uma nova família. Rio de Janeiro: Jorge Zahar Ed., p. 11-30.

Foucault, M.(1987) Vigiar e Punir - História da Violência nas Prisões. 11 edição. Petrópolis: Vozes. 
Freitas, R.M.V. (1999) Um breve panorama da nupcialidade nos anos 90. Informe GEPOP. São Paulo: Fundação SEADE, agosto, p. 1-10.

Gomes, H. S. (1994) Educação para a família: Uma proposta de trabalho preventivo. Revista Brasileira de Crescimento e Desenvolvimento Humano. São Paulo, V.4, N.1, p. 34-39.

Guimarães, A. M. (acesso em: setembro/ 2004). Escola: espaço de violência e indisciplina. Disponível em: http://lite.fae.unicamp.br/revista/art02htm..

Guirado, M. (1987) Psicologia Institucional. In: RAPPAPORT, C. R Temas Básicos de Psicologia. V. 5. São Paulo: E PU.

Jecupé, K. W. (2002) Ore awé roiru'a ma - Todas as vezes que dissemos adeus. São Paulo: TRIOM.

Lahire, B. (1997). Sucesso Escolar nos meios populares: as razões do improvável. São Paulo: Ática.

Laplanche, J. Pontalis, J.B. (1986) Vocabulário da Psicanálise. 9a edição. São Paulo: Martins Fontes.

Leloup, J. Y. (1998) Deserto, desertos. 2a edição. Petrópolis: Vozes.

Martins, J.; Bicudo, M. A V. (1994) A pesquisa qualitativa em psicologia. São Paulo: Moraes.

Medeiros, C. P. (acesso em setembro/ 2004). A disciplina escolar, a (in)disciplina do desejo. Disponível em: http://educaçãoonline.pro.br/.

Medrado, H. I. P. (1998) Formas contemporâneas de negociação com a depredação. Caderno CEDES. Campinas, V. 19, N. 47, p. 81-103. Umbrais.

Millan, B. (1976) O jogo do esconderijo: terapia em questão. São Paulo: Novos

Minayo, M. C. S. (1996) O desafio do conhecimento. metodologia qualitativa em saúde. Rio de Janeiro: Hucitec-Abrasco.

Ministry of Education, Denmark (1988). Folkeskole, primary and lower secondary education in Denmark. Skive: Hand Print A/S.

Moreno, J.L. (1984) Psicodrama. Trad. Álvaro Cabral. São Paulo: Cultrix.

Moreno, J. L. (1992) Quem sobreviverá Goiânia: Dimensão Editora,V. I.

Moreno, J.L. (1993) Psicoterapia de grupo e psicodrama Campinas: Ed. Psy.

Moscovici, S. (1978) A Representação Social da Psicanálise. Trad. Álvaro Cabral. Rio de Janeiro: Zahar Editores. 
Naffah Neto, A (1997) Psicodrama: Descolonizando o Imaginário. $2^{a}$. edição. São Paulo: Plexus.

Nicolaci-da-Costa, A M. (1985) Mal-estar na família: descontinuidade e conflito entre sistemas simbólicos. In: FIGUEIRA, S. A. (org.) Cultura da psicanálise. São Paulo: Brasiliense, p. 147-168.

Nogueira, M. A. (1998) Relação família escola: um novo objeto na sociologia da educação. Revista Paidéia, FFCLRP - USP, Ribeirão Preto, Fev./Agosto, p. 91-103.

Nogueira, C. M. M.; Nogueira M. A. (2002) A sociologia da educação de Pierre Bourdieu: limites e contribuições. Revista Educação e Sociedade, Campinas, V. 23, N. 78, abril, p. 15-35.

Oliveira, M. C. (1999) Família, escola e participação. Educação, Porto Alegre, ano XXII, N. 37, p. 151-176.

Patto, M. H. S. (1992) A família pobre a escola pública: anotações sobre um desencontro. Psicologia USP, São Paulo, 3 (1/2), p. 107-121.

Penin, S. T. S. (1993). Processo de construção do conhecimento do professor sobre o ensino: algumas mediações (movimentos entre o conhecimento sistematizado, 0 saber cotidiano e a vivência). Tese (livre-doc.), Faculdade de Educação/USP, São Paulo.

Penin, S. T. S. (1995) A professora e a construção do conhecimento sobre o ensino. Cadernos de Pesquisa, São Paulo, N. 92, p. 5-15.

Perez, M. C. A. (2000). Família e Escola na Educação a Criança: análise das representações presentes em relatos de alunos, pais e professores de uma escola pública de ensino fundamental. Dissertação de Mestrado defendido junto ao Programa de Pósgraduação em Psicologia, Departamento de Psicologia e Educação da FFCLRP - USP.

Prado, M (1996) Uma introdução aos quiprocós conjugais. In: CARNEIRO, T. F. (org.) Relação amorosa, casamento, separação e terapia de casal. Rio de Janeiro: ANPEPP, p. 17-24.

Ribeiro, D. F (2000) Recriando o papel profissional: o cuidado à pacientes HIV positivo. Monografia para obtenção do título de psicodramatista pela FEBRAP.

Romanelli, G. (1991) Mudança e Transição em famílias de camadas médias. Travessia, V.9, N.4, p.32-34.

Romanelli, G. (1995) Papéis familiares e paternidade em famílias de camadas médias. In: Reunião Anual da ANPOCS, 19, (mimeografado).

Romanelli, O. O. (1987) História da Educação no Brasil (1930/1973). Petropólis: Vozes.

Sá, C. P. (1996) Núcleo Central das Representações Sociais. Petrópolis: Vozes. 
Samartini, L. S. (1995). Gestão Participativa: Os pais na Administração da Escola, Cadernos da FFC-UNESP, Marília, V.4, N.2, p.31-36.

Sigolo, S. R. L. e Lollato, S. O. (2001). Aproximações entre escola e família: um desafio para educadores, In: CHAKUR, C. R. de S. L. (Org) Problemas de Educação sob o Olhar da Psicologia. Araraquara. FCL/ Laboratório Editorial/ UNESP; São Paulo: Cultura Acadêmica Editora, p. 37-65.

Singly, F. (2000) O nascimento do "indivíduo individualizado" e seus efeitos na vida conjugal e familiar. In: PEIXOTO, C.; SINGLY, F. de e CICCHELLI, V. (org.) Família e Individualização. Rio de Janeiro: Ed. FGV, p. 185-197.

Sousa, J. M. (2000) O olhar etnográfico da escola perante a diversidade cultural. PSI - Revista de Psicologia Social e Institucional, V. 2, N. 1.

Souza, R. F. (2000) Inovação Educacional do século XIX: A construção do Currículo da Escola Primária no Brasil. Caderno CEDES, Campinas, V. 20, N. 51, novembro, p. 9-28.

Torres, A. (2000) A individualização no feminino, o casamento e o amor. In: PEIXOTO, C.; SINGLY, F. de e CICCHELLI, V. (org.) Família e Individualização. Rio de Janeiro: Ed. FGV, p. 135-156.

Vaughn, S.; Schumm, J. S.; Sinagub, J. (1996) Focus Group Interviews in Education and Psychology. Thousand Oaks: Sage Publications.

Viana, M. J. B. (2000). Longevidade escolar em famílias de camadas populares - Algumas condições de possibilidade. In: NOGUEIRA, M. A.; ROMANELLI, G.; ZAGO, N. (Org.) Família e Escola: Trajetórias de escolarização em camadas médias e populares. Petrópolis: Editora Vozes, p. 45-60.

Xavier, R. (2002) Representação social e ideologia: conceitos intercambiáveis? Psicologia e Sociedade. Belo Horizonte, V.14, N. 2, p. 18-24.

Werebe, M. J. G. (1997) 30 anos depois - Grandezas e Misérias do Ensino no Brasil. São Paulo: Ática.

Zago, N. (1998). Realidades Sociais e Escolares e Dinâmica Familiar nos meios populares, Revista Paidéia, FFCLRP - USP, Ribeirão Preto, fev/ago, p. 45-60.

Zago, N. (2000) Processos de escolarização nos meios populares - As contradições da obrigatoriedade escolar. In: NOGUEIRA, M. A.; ROMANELLI, G.; ZAGO, N. (org.) Família e Escola: Trajetórias de escolarização em camadas médias e populares. Petrópolis: Vozes, p. 17-44. 


\section{ANEXOS}

\section{Anexo A: Modelo de termo de consentimento esclarecido}

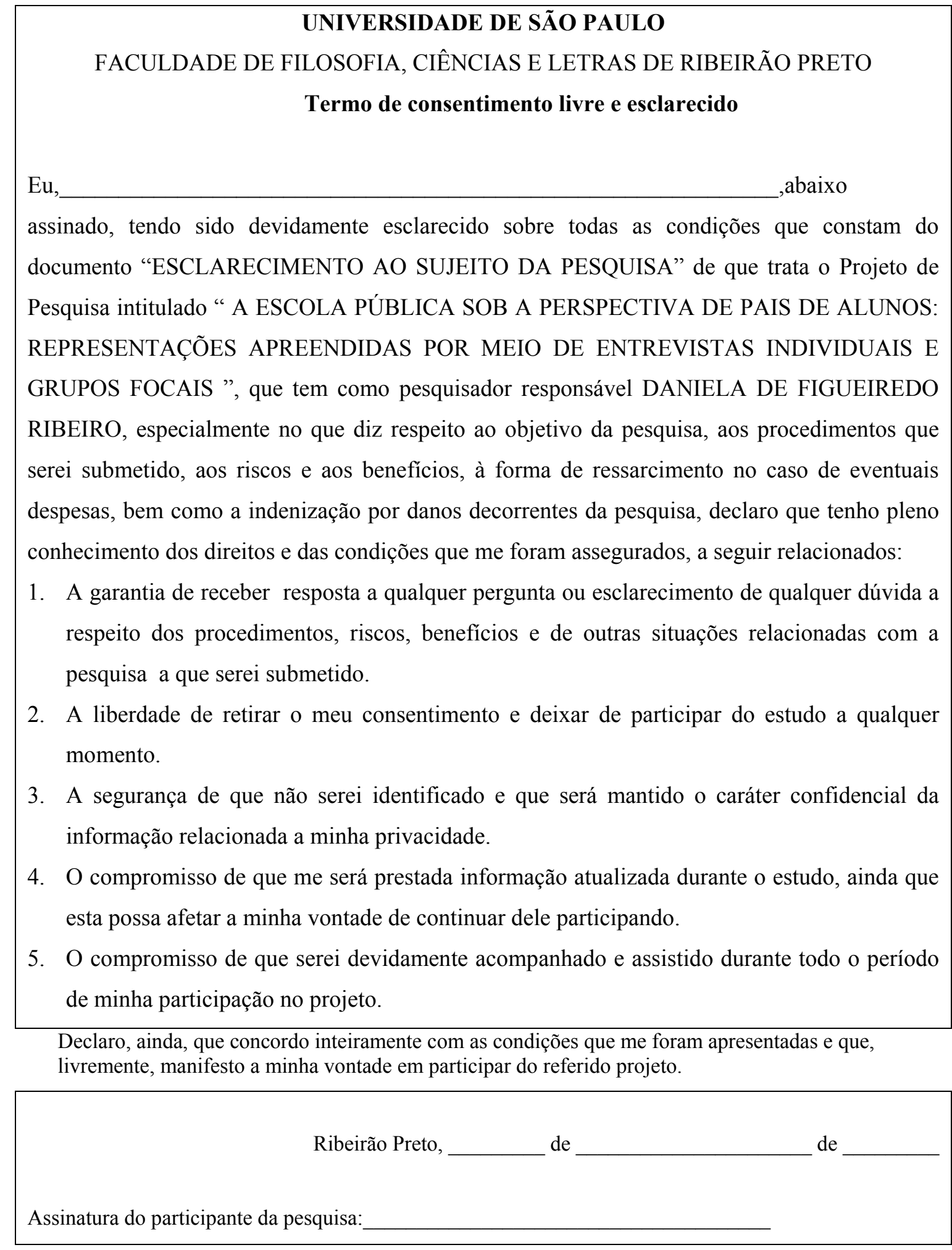




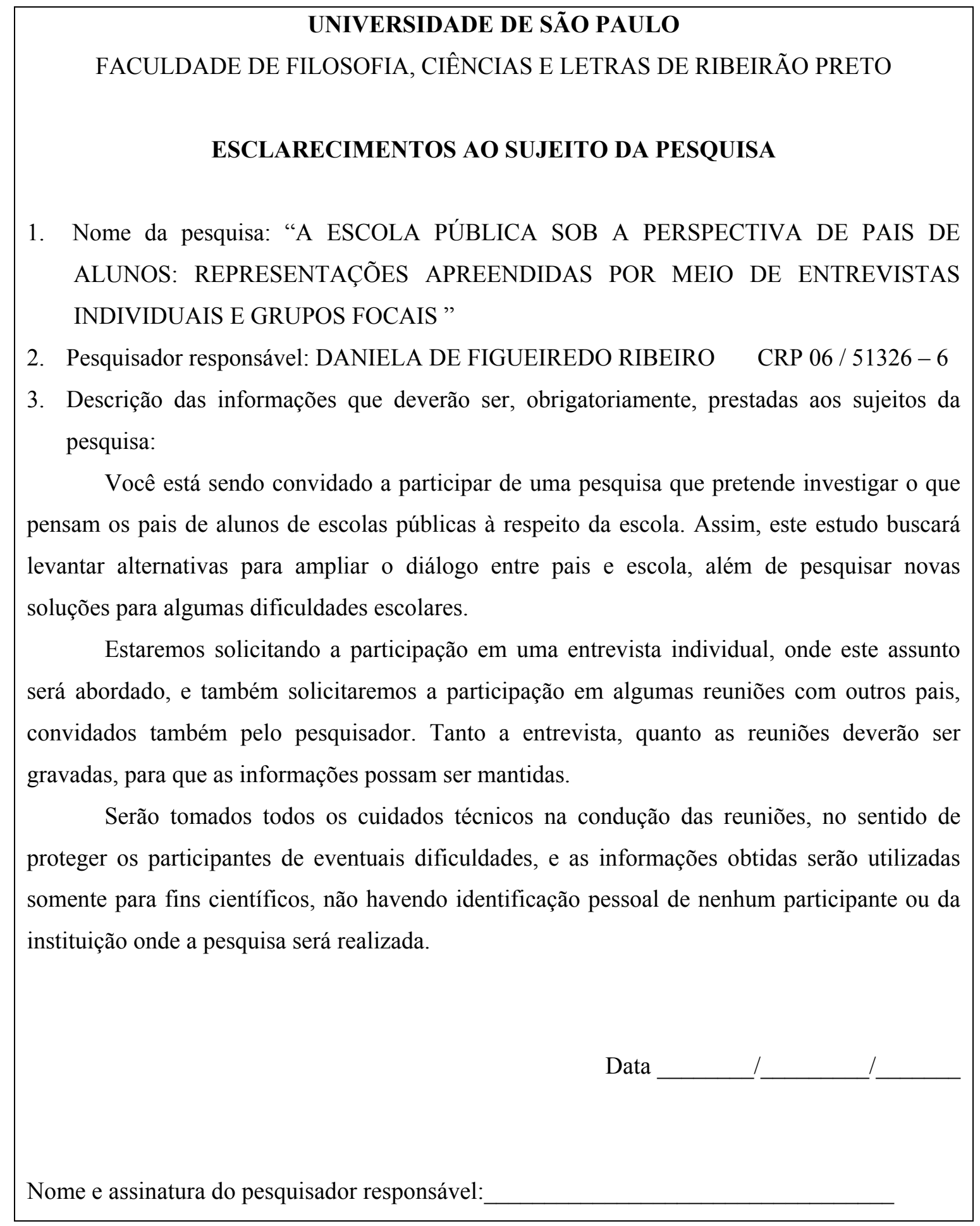




\section{Anexo B- Roteiro da Entrevista Individual}

Parte I - Aspectos a serem observados no decorrer da entrevista:

- Aspecto físico da residência

- Local da residência

- Práticas familiares

- Condições materiais das famílias

Parte II - Contextualização:

- História da família e local de origem dos pais

- Constituição familiar (número de pessoas, onde e como vivem)

- Ocupação profissional dos membros da família

- Escolaridade dos pais

Parte III - Temática:

Foram confeccionados três cartões temáticos para serem apresentados aos entrevistados, um a um, sendo solicitado a eles que pensassem sobre o assunto, deixando vir à mente tudo que lembravam a respeito do tema. Em seguida, a pesquisadora anotava as palavras chaves trazidas por eles e pedia que fossem explicadas detalhadamente. Alguns entrevistados, no entanto, já iniciavam discorrendo sobre o tema, não se detendo muito na fase reflexiva. Os cartões foram apresentados aos entrevistados na ordem exposta a seguir e continham os seguintes temas:

- "Professora do meu filho(a)"

- "Escola do meu filho(a)"

- "Escolaridade" (estudo) 